\title{
TU/e EnNHOUN

\section{Residual monomer reduction in polymer latex products by extraction with supercritical carbon dioxide}

\section{Citation for published version (APA):}

Aerts, M. (2012). Residual monomer reduction in polymer latex products by extraction with supercritical carbon dioxide. [Phd Thesis 1 (Research TU/e / Graduation TU/e), Chemical Engineering and Chemistry]. Technische Universiteit Eindhoven. https://doi.org/10.6100/IR723144

DOI:

10.6100/IR723144

Document status and date:

Published: 01/01/2012

\section{Document Version:}

Publisher's PDF, also known as Version of Record (includes final page, issue and volume numbers)

\section{Please check the document version of this publication:}

- A submitted manuscript is the version of the article upon submission and before peer-review. There can be important differences between the submitted version and the official published version of record. People interested in the research are advised to contact the author for the final version of the publication, or visit the $\mathrm{DOI}$ to the publisher's website.

- The final author version and the galley proof are versions of the publication after peer review.

- The final published version features the final layout of the paper including the volume, issue and page numbers.

Link to publication

\section{General rights}

Copyright and moral rights for the publications made accessible in the public portal are retained by the authors and/or other copyright owners and it is a condition of accessing publications that users recognise and abide by the legal requirements associated with these rights.

- Users may download and print one copy of any publication from the public portal for the purpose of private study or research.

- You may not further distribute the material or use it for any profit-making activity or commercial gain

- You may freely distribute the URL identifying the publication in the public portal.

If the publication is distributed under the terms of Article 25fa of the Dutch Copyright Act, indicated by the "Taverne" license above, please follow below link for the End User Agreement:

www.tue.nl/taverne

Take down policy

If you believe that this document breaches copyright please contact us at:

openaccess@tue.nl

providing details and we will investigate your claim. 


\section{Residual monomer reduction in polymer latex products by extraction with supercritical carbon dioxide}

\section{PROEFSCHRIFT}

ter verkrijging van de graad van doctor aan de Technische Universiteit Eindhoven, op gezag van de rector magnificus, prof.dr.ir. C.J. van Duijn, voor een commissie aangewezen door het College voor

Promoties in het openbaar te verdedigen op dinsdag 7 februari 2012 om 16.00 uur

door

Marijke Aerts

geboren te Hasselt, België 
Dit proefschrift is goedgekeurd door de promotoren:

prof.dr.ir. J.T.F. Keurentjes

en

prof.dr. J. Meuldijk

A catalogue record is available from the Eindhoven University of Technology Library ISBN: 978-90-386-3073-1

(C) 2012, Marijke Aerts

This research was financially supported by the Foundation of Emulsion Polymerization (SEP).

Cover design: Nina Middelkamp and Marijke Aerts

Printed at the Universiteitsdrukkerij, Eindhoven University of Technology 
Niet alles draait om carrière en geld Maar ook om liefde en vriendschap die je kunt geven, Pas dan ben je ook geslaagd als mens voor de rest van je leven. 



\section{Table of Contents}

Table of contents $\quad$ i

Summary iii

Samenvatting v v

Chapter 1 Introduction: Residual monomer reduction in polymer emulsion polymerization products: Limitations and challenges

Chapter 2 Partitioning of residual monomer between polymer and $\mathrm{CO}_{2}$ - A theoretical approach

Chapter 3 Experimental determination of the partition coefficient of monomers over polymer and supercritical carbon dioxide

Chapter 4 Mass transport phenomena in the supercritical carbon dioxide extraction of residual monomer from latex products

Chapter 5 Process design for the residual monomer reduction in latex with supercritical carbon dioxide

Chapter 6 High pressure carbon dioxide in the extraction of residual monomer from latex products: additional results and outlook

Notation

Dankwoord 



\section{Summary}

\section{Residual monomer reduction in polymer (latex) products by extraction with supercritical carbon dioxide}

The increased awareness for environmental issues as well as for public health, demands "greener" processes as well as products. In the polymer industry, one of the major concerns relate to residual monomer in polymer (latex) products. Low molecular species are toxic. When monomer units diffuse out of their polymeric matrix, they contaminate the surrounding area. Decreasing the residual monomer level in polymer (latex) products is especially of great importance in food packaging, toys for children, etc. Conventional techniques to reduce residual monomer in polymer (latex) products are energy intensive, time consuming and not able to fulfill the increasingly stringent requirements for further reduction of residual monomer in polymer products, i.e. $<100$ parts per million (ppm).

In this thesis the reduction of residual monomer in polymer (latex) products by extraction with supercritical carbon dioxide $\left(\mathrm{SCCO}_{2}\right)$ is explored. The Peng-Robinson equation of state has been used to describe the binary phase diagram of $\mathrm{CO}_{2}$ and styrene as well as of $\mathrm{CO}_{2}$ and methyl methacrylate. The ternary phase diagram of $\mathrm{CO}_{2}$-styrene-polystyrene as well as of $\mathrm{CO}_{2}$-methyl methacrylate-polymethyl methacrylate has been estimated with the Perturbed Chain - Statistical Associated Fluid Theory. The partition coefficient of the distribution of monomer between $\mathrm{CO}_{2}$ and $\mathrm{CO}_{2}$ swollen polymer has been calculated.

In a high pressure autoclave the partition coefficient of the distribution of monomer between $\mathrm{CO}_{2}$ and $\mathrm{CO}_{2}$ swollen polymer has been determined experimentally at a range of temperatures and pressures. The experimental results demonstrate the partition coefficient is approximately independent of pressure and temperature. For the partitioning of styrene between $\mathrm{CO}_{2}$ and $\mathrm{CO}_{2}$ swollen polystyrene a value of 2 [kg PS/kg CO $\mathrm{CO}_{2}$ has been found, while for the partitioning of methyl methacrylate between $\mathrm{CO}_{2}$ and $\mathrm{CO}_{2}$ swollen polymethyl methacrylate a value of $0.3[\mathrm{~kg} \mathrm{PMMA} / \mathrm{kg} \mathrm{CO}$ ] has been determined.

Mass transport of monomer from the polymer phase to the $\mathrm{CO}_{2}$ phase is governed by the shuttle effect. The monomer is hereby directly transferred from the polymer particles to the 
$\mathrm{CO}_{2}$ phase due to Brownian motion of the particles to and from the $\mathrm{CO}_{2} / \mathrm{H}_{2} \mathrm{O}$ interface. The main resistance against mass transfer has been demonstrated to be located in the polymer particles.

The countercurrent extraction process to reduce residual monomer in polymer (latex) products from $10^{4} \mathrm{ppm}$ to $1 \mathrm{ppm}$ in a column has been designed. Latex has been chosen as the continuous phase in which $1 \mathrm{~mm} \mathrm{CO}$ bubbles are dispersed with a hold up of $20 \%$. The column is operated at 100 bar and $35{ }^{\circ} \mathrm{C}$. A column volume of $4.75 \mathrm{~m}^{3}$ applies for a throughput of $6000 \mathrm{~kg}$ PS latex (45\% solids)/hr. The extraction process reducing the residual monomer costs $22 € /$ ton latex for a production capacity of $50 \mathrm{kt}$ PS latex (45\% solids)/yr. Continuous steam stripping only costs $12 € /$ ton latex to reduce the residual monomer level from $10^{4}$ to $100 \mathrm{ppm}$, whereas the purification costs of the $\mathrm{CO}_{2}$-based extraction process are similar for a reduction to 100,10 or 1 ppm. Reduction to lower levels of residual monomer, lower than $100 \mathrm{ppm}$, by means of steam stripping is hardly possible, mainly due to thermodynamic (and to some extent transport) limitations. The results of calculations for a residual monomer reduction from $10^{4}$ to $10 \mathrm{ppm}$ with $100{ }^{\circ} \mathrm{C}$ steam point to a tremendous increase of the utility costs. The costs of a continuous steam stripping process are then more than $75 € /$ ton latex. The lowest residual monomer concentration in latex of $1 \mathrm{ppm}$ can certainly only be achieved by extraction with $(\mathrm{sc}) \mathrm{CO}_{2}$. 


\section{Samenvatting}

\section{Verminderen van het restmonomeer gehalte in polymeren door middel van extractie met superkritisch kooldioxide}

"Groene" processen en producten worden steeds belangrijker in het dagelijkse leven door de groeiende bezorgdheid om ons milieu, onze gezondheid en de beschikbaarheid van (fossiele) grondstoffen. Eén van de grootste aandachtspunten bij de productie van polymere materialen is het restmonomeer gehalte. Vooral in onder andere verpakkingsmateriaal voor voeding en in speelgoed is het verminderen van restmonomeer van groot belang. De technieken die nu gebruikt worden om restmonomeer in polymeer producten te verlagen zijn tijdrovend, kosten veel energie en kunnen het restmonomeer gehalte niet tot het gewenste niveau doen dalen, dat wil zeggen tot niveaus duidelijk lager dan 100 ppm.

In het in dit proefschrift beschreven werk is de extractie van restmonomeer uit polymeren door middel van superkritisch $\mathrm{CO}_{2}\left(\mathrm{scCO}_{2}\right)$ bestudeerd. Het binaire fasengedrag van zowel $\mathrm{CO}_{2}$ en styreen als van $\mathrm{CO}_{2}$ en methyl methacrylaat werd beschreven met de PengRobinson toestandsvergelijking. Het ternaire fasendiagram van $\mathrm{CO}_{2}$-styreen-polystyreen en van $\mathrm{CO}_{2}$-methyl methacrylaat-polymethyl methacrylaat werd in kaart gebracht met de Perturbed Chain - Statistical Associated Fluid Theory (PC SAFT). De verdelingscoefficient van monomeer over de $\mathrm{CO}_{2}$-fase en het polymeer gezwollen met $\mathrm{CO}_{2}$ is berekend met het PC SAFT model.

De experimentele bepaling van de verdelingscoefficient van monomeer over de $\mathrm{CO}_{2}$ fase en het polymeer gezwollen met $\mathrm{CO}_{2}$ werd uitgevoerd in een hoge druk cel bij verschillende drukken en temperaturen. De experimentele resultaten laten zien dat de verdelingscoefficient nagenoeg onafhankelijk is van druk en temperatuur. De gemeten waarden van de verdelingscoëfficiënt wijken aanzienlijk af van de met PC SAFT berekende waarden. De reden voor deze verschillen tussen de berekende en gemeten waarden is waarschijnlijk het uitgangspunt bij de berekeningen. Bij de berekeningen is uitgegaan van een ideaal polymeer zonder verknopingen (entanglements). Voor de metingen zijn niet-behandelde reactorproducten gebruikt. 
Het zogenaamde 'shuttle effect' domineert monomeer transport van de polymeer fase naar de $\mathrm{CO}_{2}$ fase. De polymeerdeeltjes bewegen naar en van het $\mathrm{CO}_{2} / \mathrm{H}_{2} \mathrm{O}$ grensvlak ten gevolge van de Brownse beweging. Hierdoor ontstaat er een direct contact tussen het polymeerdeeltje en $\mathrm{CO}_{2}$, waardoor monomeer direct wordt overgedragen naar het $\mathrm{CO}_{2}$. De grootste weerstand tegen het monomeertransport ligt in de polymeerdeeltjes.

Het tegenstroom extractie proces om het restmonomeer gehalte in polymeer te verlagen van $10^{4}$ naar $1 \mathrm{ppm}$ is ontworpen als een kolomproces. Latex is hierin de continue fase waarin 1 $\mathrm{mm} \mathrm{CO}_{2}$ druppels worden gedispergeerd met een volumefractie van 0,2. De extractiekolom is ontworpen voor een druk van 100 bar en een temperatuur van $35^{\circ} \mathrm{C}$. Voor het verwerken van $6000 \mathrm{~kg}$ PS latex (45\% droge stof)/uur, is een kolomvolume van $4.75 \mathrm{~m}^{3}$ berekend. De kosten van de extractie van restmonomeer zijn geschat op $22 € /$ ton latex voor een productie capaciteit van $50 * 10^{3}$ ton PS latex $(45 \%$ droge stof)/jaar. Het verminderen van restmonomeer van $10^{4}$ tot $100 \mathrm{ppm}$ met stoomstrippen als continu proces kost slechts 12 $€ /$ ton latex. De kosten voor de extractie met $\mathrm{CO}_{2}$ van $10^{4} \mathrm{ppm}$ restmonomeer naar 100,10 of 1 ppm blijven echter ongeveer gelijk. Mogelijkheden om het restmonomeergehalte met stoomstrippen verder te verlagen dan 100 ppm zijn zeer beperkt, omdat het proces zowel thermodynamisch als wat betreft monomeertransport in de polymeerdeeltjes is gelimiteerd. Een berekening voor het verlagen van restmonomeer van $10^{4}$ naar $10 \mathrm{ppm}$ met stoom strippen toont een enorme stijging van de proceskosten, voornamelijk door de grote hoeveelheid stoom die verbruikt wordt. Het continue stoom strip proces kost dan maar liefst $75 € /$ ton latex. Een restmonomeer niveau van 1 ppm kan enkel worden bereikt door middel van extractie met $\mathrm{scCO}_{2}$. 




\section{Chapter 1}

\section{Introduction: Residual monomer reduction in polymer emulsion polymerization products: Limitations and challenges}

\section{Introduction}

Emulsion polymerization is frequently used in industry to produce e.g. adhesives, latex paints, coatings and rubbers (Gilbert, 1995). Emulsion polymerization is a free radical polymerization in a heterogeneous reaction system, yielding a colloidally stable dispersion of submicron polymer particles in an aqueous medium. The process is governed by a complex mechanism, see e.g. Gilbert (1995) and van Herk (2005). In many cases three time-separated stages can be distinguished in a batch process, i.e. particle nucleation, particle growth in the presence of monomer droplets and completion of the polymerization when the monomer droplets have been consumed. A simple description of the mechanism of emulsion polymerization has first been given by Harkins (1947) and later worked out by Smith and Ewart (1948). Many research groups have studied the emulsion polymerization process, see e.g. Hansen and Ugelstad (1982), Gilbert (1995), van Herk (2005), De la Cal et al. (2005) and De Cal et al. (2007). However, complete insight into the whole process has not been reached up to now. In general, emulsion polymerization yields a high molecular weight polymer product. Typical values of the degree of polymerization are mostly considerable larger than $10^{3}$. Molecular mass can e.g. be reduced by chain transfer agents. In the last stage of the process the rate of polymerization will decrease due to the decreasing monomer concentration inside the particles. Due to diffusion limitations in the particle phase the polymerization reaction will not proceed to completion. As a consequence, the polymer 
latex product contains a significant amount of residual monomer inside the polymer particles, generally in the range of a thousand parts per million (ppm). Reduction of the residual monomer level in polymer latex products is essential for safe and non-toxic use. Moreover, increasingly stringent requirements demand for further reduction of residual monomer in polymer products. Various conventional techniques to reduce the residual monomer level in polymer latex products are energy intensive (e.g. steam stripping, Englund, 1981), time consuming (e.g. temperature increase) or even might change the product properties (e.g. addition of initiator). Most important, conventional techniques are not able to fulfill the stringent requirements as the result of thermodynamic and transport limitations.

\section{Thermodynamic limitation}

At high conversions $(X>99 \%)$, i.e. high polymer volume fractions $\left(\phi_{\mathrm{P}}\right)$, the activity coefficient of low molecular weight species molecularly dissolved in the polymer phase is very low. Consequently, monomer partitioning between the polymer phase and the vapor phase is characterized by very low monomer partial pressures in the vapor phase, see Equation 1 and Figure 1 . Note that the activity coefficient decreases upon reduction of the volume fraction of low molecular weight species, e.g. residual monomer.

$\mathrm{y}_{\mathrm{m}} * \mathrm{P}_{\text {total }}=\gamma_{\mathrm{m}} * \mathrm{x}_{\mathrm{m}} * \mathrm{P}_{\mathrm{m}}^{\text {sat }}$ 


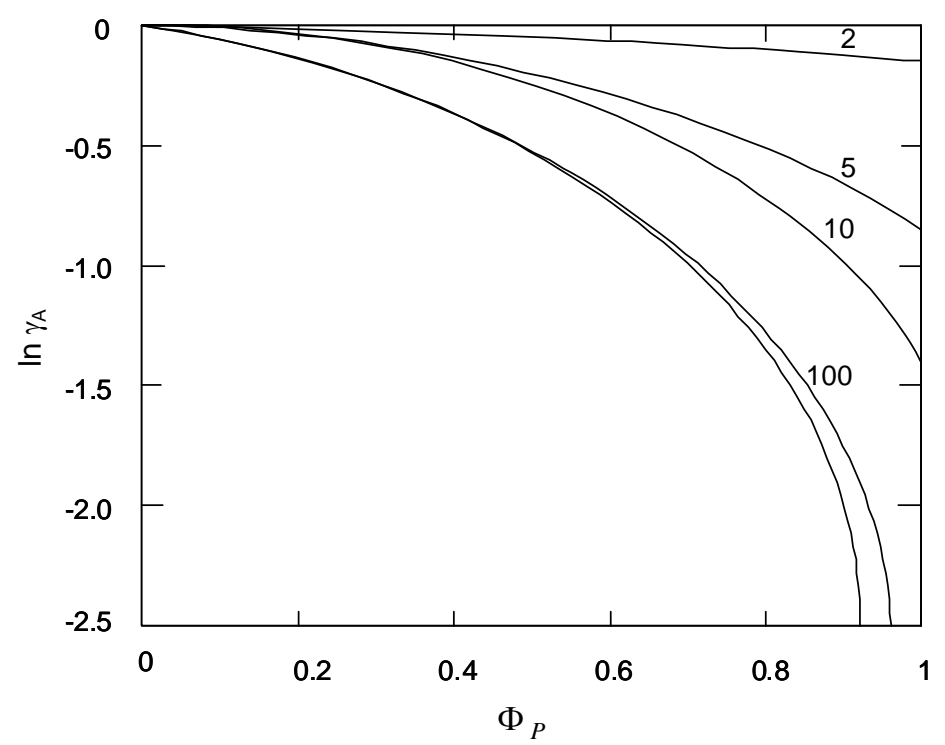

Figure 1 Monomer activity coefficient in a polymer solution as calculated with the FloryHuggins model (Flory (1953)) for athermic polymer solutions;

$\ln \gamma_{\mathrm{A}}=\ln \left[1-\left(1-\frac{1}{\mathrm{~m}}\right)\right] * \Phi_{P}+\left(1-\frac{1}{m}\right) * \Phi_{P}, \mathrm{~m}$ stands for the degree of polymerization.

Reduction of the residual monomer to a level of a few ppm is in general not possible with steam stripping in equipment with a realistic size.

\section{Transport limitation}

The time constants for monomer transport in the polymer phase are very high. The diffusion coefficient $\left(D_{\text {mon }}^{P}\right)$ of monomer in the polymer is in the order of magnitude of $10^{-15} \frac{\mathrm{m}^{2}}{\mathrm{~s}}$, or even lower.

Pressurized carbon dioxide as alternative method to reduce residual monomer in polymer products

An alternative technique to reduce the residual monomer amount in polymer latex systems is the extraction with high pressure carbon dioxide $\left(\mathrm{CO}_{2}\right)$. Pressurized $\mathrm{CO}_{2}$ has 
several advantages to be used as extraction medium. At conditions above the critical temperature $(304 \mathrm{~K})$ and the critical pressure (73 bar) of $\mathrm{CO}_{2}$ (Poling et al., 2001), the physical properties lie between those of a liquid and a gas, combining favorable qualities of the liquid phase as well as the gas phase, see Table 1. For example, at high pressures a SCF has solubility and density properties close to those of a liquid, but with considerable larger diffusion coefficients and lower viscosity.

Table 1 Typical properties of gases, supercritical fluids (SCF) and liquids

\begin{tabular}{l|c|c|c}
\hline property & gas & SCF & liquid \\
\hline \hline density $\left(\mathrm{kg} / \mathrm{m}^{3}\right)$ & 1 & $100-800$ & 1000 \\
\hline viscosity $(\mathrm{mPa} . \mathrm{s})$ & 0.01 & $0.05-0.1$ & $0.5-1$ \\
\hline diffusivity $\left(\mathrm{m}^{2} / \mathrm{s}\right)$ & $10^{-5}$ & $10^{-7}$ & $10^{-9}$ \\
\hline
\end{tabular}

High pressure extraction with near supercritical or supercritical fluids (SCF) has been in use for several decades on an industrial scale (Kilzer et al., 2011, Morgan, 2000, Araújo, 2002), e.g. for the decaffeination of coffee. Relatively small changes in the $\mathrm{CO}_{2}$ pressure as well as in temperature result in large density changes favoring the extraction process. The most important advantage of using high pressure $\mathrm{CO}_{2}$ is that $\mathrm{CO}_{2}$ increases the fugacity of the monomer in the polymer phase (i.e. decreasing $\phi_{\mathrm{P}}$ by swelling the polymer with $\mathrm{CO}_{2}$ ), thereby increasing the monomer molar fraction in the gas or SCF phase, see Equation 1.

Note that as a result of swelling the polymer is softened and plasticized. Monomer transport rates (in terms of $\mathrm{D}_{\text {mon }}^{\mathrm{P}}$ ) in the polymer phase swollen with $\mathrm{CO}_{2}$ increase from values $\leq 10^{-15} \frac{\mathrm{m}^{2}}{\mathrm{~s}}$ to about $10^{-12} \frac{\mathrm{m}^{2}}{\mathrm{~s}}$ or even higher (Alsoy and Duda, 1998), leading to improved monomer transport rates compared to e.g. steam stripping. Note that for highly amorphous or rubbery polymers, a maximum can be reached in the mass transfer rate with increasing pressure (Vandenburg, 2000). With increasing pressure, i.e. more $\mathrm{CO}_{2}$ uptake in the polymer matrix, the softening point of the polymer, i.e. the glass transition temperature $T_{g}$, decreases. If $T_{g}$ falls below the operation temperature in the extraction process, the polymer particles will become sticky and the extraction process is 
hampered by fouling. Alessi et al. (2003) as well as Zhang and Handa (1998) reported the experimentally determined decrease in $T_{g}$ of polystyrene (PS) as well as of polymethyl methacrylate (PMMA) with increasing pressure of $\mathrm{CO}_{2}$ at a constant temperature, see Table 2.

Table 2 Decrease in the glass transition temperature $\left(\mathrm{T}_{\mathrm{g}}\right)$ in $\mathrm{CO}_{2}$ swollen polymers as a function of pressure (Alessi et al., 2003, Zhang and Handa, 1998)

\begin{tabular}{c|c|c|c|c|c}
\hline & \multicolumn{6}{|c}{$\mathrm{P}_{\mathrm{CO}_{2}}[\mathrm{bar}]$} \\
& 0 & 10 & 20 & 30 & 40 \\
\hline \hline $\mathrm{PS} \mathrm{T}_{\mathrm{g}}\left[{ }^{\circ} \mathrm{C}\right]$ & 102 & 95 & 87 & 79 & 69 \\
\hline PMMA T $_{\mathrm{g}}\left[{ }^{\circ} \mathrm{C}\right]$ & 105 & 95 & 79 & 68 & 57 \\
\hline
\end{tabular}

Moreover, due to the low polarizability of $\mathrm{CO}_{2}$, along with the lack of a dipole moment, nonvolatile polar molecules, surfactants and nearly all polymers are not or very sparsely soluble in $(\mathrm{sc}) \mathrm{CO}_{2}$. Most commonly used monomers are moderately or well soluble in supercritical or liquid $\mathrm{CO}_{2}$.

So partitioning of monomer or other low molecular weight species (e.g. Diels-Alder adducts in styrene-butadiene based products) towards $\mathrm{CO}_{2}$ is sufficiently good to allow application of supercritical or liquid $\mathrm{CO}_{2}$ in an extraction process to reduce the level of residual monomer or other low molecular weight species.

\section{Outline of this thesis}

In the present work, aspects of thermodynamic phase behavior of PS as well as PMMA latex systems in a high pressure $\mathrm{CO}_{2}$ atmosphere are reported in Chapters 2 and $\mathbf{3}$. Chapter 4 discusses the mass transfer phenomena involved in the extraction of residual monomer with $\mathrm{CO}_{2}$. Based on experimental data (the partition coefficient $\left(\mathrm{K}_{\text {mon }}\right)$ for the distribution of monomer between the $\mathrm{CO}_{2}$ swollen polymer and $\mathrm{CO}_{2}$ ) as well as on 
theoretically predicted parameters (dispersed phase hold up, droplet size) the design of an extraction process is described in Chapter 5. In Chapter 5 also an economic evaluation of the $\mathrm{CO}_{2}$ based extraction process is given. The results of this evaluation are compared with the results of a cost estimation of a steam stripping process. In Chapter 6 additional comments as well as the challenges and opportunities in field of extraction of residual monomer from polymer (latex) products with $\mathrm{scCO}_{2}$ are presented. 


\section{References}

P. Alessi, A. Cortesi, I. Kikic, F. Vecchione, "Plasticization of polymers with supercritical carbon dioxide: Experimental determination of glass-transition temperatures", J. Appl. Polym. Sci., 2003, 88, 2189-2193

S. Alsoy, J. L. Duda, "Supercritical devolatilization of polymers", AlChE, 1998, 44, 3, $582-590$

P. H. H. Araújo, C. Sayer, J. G. R. Poço, R. Guidici, "Techniques for reducing residual monomer content in polymers: A review", Polym. Eng. Sci., 2002, 42, 7

J. C. De La Cal, J. R. Leiza, J. M. Asua, A. Buttè, G. Storti, M. Morbidelli, "Emulsion polymerization", in "Handbook of polymer reaction engineering", J. T. F. Keurentjes, T. Meyer, Eds., 2005, Wiley-VCH, Weinheim

J. C. De La Cal, Chapter 6 in "Polymer reaction engineering", J. M. Asua, Ed., 2007, Blackwell, Oxford

S. M. Englund, "Monomer removal from latex", Chem. Eng. Progr., 1981, 55-59; and references therein

R. G. Gilbert, "Emulsion polymerization, A mechanistic approach", Academic Press, 1995

Hansen, Ugelstad, Chapter 6 in "Emulsion polymerization, I. Piirma, Ed., Academic Press, 1982, London

A. M. van Herk, "Chemistry and technology of Emulsion polymerization", Ed., 2005 Blackwell, Oxford

A. Kilzer, S. Kareth, E. Weidner, "Neue Entwicklungen bei Reinigungs- und Trennprozessen mit über- und nahkritischen Fluiden", Chemie Ingenieur Technik, 2011, 83, 9, 1405-1418

E. D. Morgan, "III/Natural products/Supercritical fluid extraction", Academic Press, 2000

Z. Zhang, Y. P. Handa, "An in situ study of plasticization of polymers by high-pressure gases”, J. Polym. Sci., Part B: Polym. Phys., 1998, 36, 977-982

H. J. Vandenburg, "III/Polymers/Supercritical fluid extraction", Academic Press, 2000 

Chapter 2

\title{
Partitioning of residual monomer between polymer and $\mathrm{CO}_{2}$
}

\section{- A theoretical approach}

\begin{abstract}
The efficiency of high pressure carbon dioxide to reduce residual monomer level in polymer products strongly depends on the monomer partitioning over the various phases involved in the separation process.

Phase behavior of the styrene - carbon dioxide as well as of the methyl methacrylate carbon dioxide binary systems has been modeled with the Peng-Robinson equation of state. Monomer partitioning between the polystyrene or polymethyl methacrylate phase and the $\mathrm{CO}_{2}$ phase has been estimated with the Perturbed Chain - Statistical Associated Fluid Theory (PC-SAFT).
\end{abstract}

\section{Introduction}

Extraction with supercritical or high pressure carbon dioxide $\left((\mathrm{sc}) \mathrm{CO}_{2}\right)$ is an interesting alternative to e.g. steam stripping to reduce the residual monomer level in polymer (latex) products. Knowledge of the phase behavior of the system monomer/polymer (latex)/(sc) $\mathrm{CO}_{2}$ as a function of various operating conditions is a necessary prerequisite for process design. 
Vapor-liquid phase equilibria at high pressure

For every component $\mathrm{i}$ in the mixture, the condition of thermodynamic equilibrium is the fugacity of a component is equal in all phases involved, see Equation 1 (Poling et al., 2001, Prausnitz and Ghmeling, 1979).

$\hat{\mathrm{f}}_{\mathrm{i}}^{(1)}=\hat{\mathrm{f}}_{\mathrm{i}}^{(2)}$

The fugacity of a component in a mixture depends on temperature, pressure and composition of the particular mixture. The relation between fugacity, pressure, temperature and composition is expressed in the fugacity coefficient, Equations 2 and 3.

$\mathrm{f}_{\mathrm{i}}^{(\mathrm{V})}=\varphi_{\mathrm{i}}{ }^{*} \mathrm{y}_{\mathrm{i}} * \mathrm{P} \quad$ for the vapor phase

$\mathrm{f}_{\mathrm{i}}^{(\mathrm{L})}=\gamma_{\mathrm{i}} * \mathrm{x}_{\mathrm{i}} * \mathrm{f}_{\mathrm{i}}{ }^{(\mathrm{L})}=\gamma_{\mathrm{i}}^{*} \mathrm{x}_{\mathrm{i}} * \varphi_{\mathrm{i}}^{\text {sat }} * \mathrm{P}_{\mathrm{i}}^{\text {sat }} \quad$ for the liquid phase

The fugacity coefficient of the vapor and liquid phase can be calculated from vapor phase data, usually introduced by an equation of state $^{1}$. An equation of state is an algebraic relation between pressure, volume and temperature.

For liquids, the fugacity of component $i$ in the liquid phase can also be calculated by another approach, the activity coefficient approach. The activity coefficient is expressed in Equation 4 (see Appendix A).

$\left(\frac{\partial \mathrm{n}^{*} \mathrm{G}^{\mathrm{E}}}{\partial \mathrm{n}_{\mathrm{i}}}\right)_{\mathrm{P}, \mathrm{T}, \mathrm{n}_{\mathrm{j}}}=\mu_{\mathrm{i}}^{\mathrm{E}}=\mathrm{R} \mathrm{T} \ln \gamma_{\mathrm{i}}$

The activity coefficient must obey the Gibbs-Duhem criterion, i.e. $\sum \mathrm{x}_{\mathrm{i}}\left(\mathrm{d} \ln \gamma_{\mathrm{i}}\right)_{\mathrm{p}, \mathrm{T}}=0$.

While liquid properties are generally not sensitive to pressure changes, pressure effects become only significant in high pressure systems, especially in systems containing supercritical components. The activity coefficient approach to determine the liquid fugacity coefficient is therefore not practical in high pressure systems. Describing high pressure phase equilibria, the fugacity coefficient of both the liquid and vapor phase is calculated with an appropriate equation of state. The fugacity coefficient of a component $i$ in a mixture, derived from the chemical potential, is expressed in Equation 5 (Sadowski, 2003).

\footnotetext{
${ }^{1}$ At low pressures it is often assumed $\varphi_{\mathrm{i}}^{\mathrm{V}}=\frac{\mathrm{f}_{\mathrm{i}}}{\mathrm{y}_{\mathrm{i}} * \mathrm{P}}=1$ (Poling et al., 2001)
} 
$\mathrm{R} T \ln \varphi_{\mathrm{i}}=\int_{\mathrm{V}}^{\infty}\left[\left(\frac{\partial \mathrm{P}}{\partial \mathrm{n}_{\mathrm{i}}}\right)_{\mathrm{T}, \mathrm{V}, \mathrm{n}_{\mathrm{i} \neq \mathrm{j}}}-\frac{\mathrm{RT}}{\mathrm{V}}\right] \mathrm{dV}-\mathrm{R} \mathrm{T} \ln \mathrm{Z}$

An typical Van der Waals type equation of state able to describe the pressure, volume, temperature relation for high pressure and supercritical fluids is the semi empirical equation of state reported by Peng and Robinson (1976). The Peng-Robinson equation of state expresses pressure as the sum of a repulsive term and an attractive term, Equation 6.

$P=\frac{R T}{v-b}-\frac{a(T, \omega)}{v(v+b)+b(v-b)}$

The parameter $a(T, \omega)$ reflects the temperature dependent intermolecular attraction. The parameter $b$ reflects the Van der Waals hard sphere volume. For pure components, $a$ and $b$ can be estimated from the critical pressure $\left(P_{c}\right)$ and the critical temperature $\left(T_{c}\right)$, see Equations 7 and 8 (Peng and Robinson, 1976, Prausnitz and Gmehling, 1979).

$$
\begin{aligned}
& \mathrm{a}(\mathrm{T}, \omega)=0.45724 \frac{\left(\mathrm{RT}_{\mathrm{c}}\right)^{2}}{\mathrm{P}_{\mathrm{c}}}\left[1+\left(0.37464+1.54226 \omega-0.26992 \omega^{2}\right)\left(1-\sqrt{\mathrm{T}_{\mathrm{r}}}\right)\right]^{2} \\
& \mathrm{~b}=0.07780 \frac{\mathrm{RT}_{\mathrm{c}}}{\mathrm{P}_{\mathrm{c}}}
\end{aligned}
$$

Applying Equation 5, the following expression for the fugacity coefficient of component $i$ in a mixture has been derived (Peng and Robinson, 1976).

$$
\begin{aligned}
& \ln \widehat{\varphi}_{\mathrm{i}}=\ln \frac{\hat{\mathrm{f}}_{\mathrm{i}}}{\mathrm{x}_{\mathrm{i}} \mathrm{P}}=\frac{\mathrm{b}_{\mathrm{i}}}{\mathrm{b}_{\text {mix }}}(\mathrm{Z}-1)-\ln (\mathrm{Z}-\mathrm{B})-\frac{\mathrm{A}}{2 \sqrt{2} \mathrm{~B}}\left(\frac{2 * \sum_{\mathrm{k}} \mathrm{x}_{\mathrm{k}} \mathrm{a}_{\mathrm{ki}}}{\mathrm{a}_{\text {mix }}}-\frac{\mathrm{b}_{\mathrm{i}}}{\mathrm{b}_{\text {mix }}}\right) \ln \left(\frac{\mathrm{Z}+2.414 \mathrm{~B}}{\mathrm{Z}-0.414 \mathrm{~B}}\right) \\
& \mathrm{A}=\frac{\mathrm{a}_{\text {mix }} \mathrm{P}}{\mathrm{R}^{2} \mathrm{~T}^{2}} \\
& \text { where } \\
& \mathrm{B}=\frac{\mathrm{b}_{\text {mix }} \mathrm{P}}{\mathrm{RT}} \\
& \mathrm{Z}=\frac{\mathrm{P} \mathrm{v}}{\mathrm{RT}}
\end{aligned}
$$

The mixture parameters used in Equation 9 follow from mixing rules, e.g.

$$
\begin{aligned}
& \mathrm{a}_{\text {mix }}=\sum_{\mathrm{i}=1}^{\mathrm{m}} \sum_{\mathrm{j}=1}^{\mathrm{m}} \mathrm{x}_{\mathrm{i}} * \mathrm{x}_{\mathrm{j}} * \mathrm{a}_{\mathrm{ij}} \\
& \mathrm{b}_{\text {mix }}=\sum_{\mathrm{i}=1}^{\mathrm{m}} \sum_{\mathrm{j}=1}^{\mathrm{m}} \mathrm{x}_{\mathrm{i}} * \mathrm{x}_{\mathrm{j}} * \mathrm{~b}_{\mathrm{ij}}
\end{aligned}
$$

Various expressions have been proposed to calculate the mixture coefficients $a_{\text {mix }}$ and $b_{\text {mix }}$ (Panagioutopoulos and Reid, 1985, Stryjek and Vera, 1986, Michelsen and Kistenmacher, 1990, Mathias and Klotz, 1991, Wong and Sandler, 1992). In the present work, the quadratic 
mixing rule has been chosen to estimate the cross parameter $a_{i j}$, Equation 15 (Poling et al., 2001).

$\mathrm{a}_{\mathrm{ij}}=\left(\mathrm{a}_{\mathrm{i}} * \mathrm{a}_{\mathrm{j}}\right)^{0.5} *\left(1-\mathrm{k}_{\mathrm{ij}}\right)$

The cross parameter $b_{i j}$ is often neglected due to its very small contribution to the description of phase equilibria. For simplicity, $b_{\text {mix }}$ is expressed with a linear equation, Equation 16 (Han et al., 1988).

$\mathrm{b}_{\text {mix }}=\sum_{\mathrm{i}=1}^{\mathrm{m}} \mathrm{x}_{\mathrm{i}} * \mathrm{~b}_{\mathrm{i}}$

Phase equilibria in polymer solutions

Thermodynamic modeling of phase behavior when polymers are involved, requires a model that is able to account for the dissimilarity in size between the different molecules, the polymer and solvent interactions and for the pressure dependence. The well known FloryHuggins theory (Smith et al., 2001, Prausnitz and Gmehling, 1979) is in general not able to describe the pressure influence. The Sanchez-Lacombe model (Sanchez and Lacombe, 1976) does take into account the requirements mentioned before, but a large set of parameters has to be determined. An alternative approach is the perturbed chain statistical associated fluid theory (PC-SAFT) equation of state (Gross and Sadowski, 2000, 2001), particularly developed for the thermodynamic modeling of systems containing both compressible components as well as chain-like molecules such as polymers. The PC-SAFT equation of state shows great similarity with the well known SAFT equation of state developed by Chapman et al. (1989). Both equations require three pure component parameters to describe a system: the number of segments, the size of the segments, and the energy related to the interaction of two segments. To describe a binary system, a binary interaction parameter $\mathrm{k}_{\mathrm{ij}}$ is included correcting for the intermolecular interactions with respect to the pure components. Both models can be written as separate contributions to the Helmholtz energy, Equation 17,

$\mathrm{A}^{\mathrm{res}}=\mathrm{A}^{\mathrm{ref}}+\mathrm{A}^{\text {pert }}$ 
The residual Helmholtz energy (deviation from the ideal gas state) of a system is the sum of the contributions of a reference system and a perturbation term. The reference system covers the repulsive interactions of the molecules, the perturbation term includes all kinds of attractive contributions, e.g. chain formation, dispersion, etc.. In contrast to the SAFT equation of state (Chapman et al., 1989) where the reference system is the hard sphere system, the reference system in the PC-SAFT equation of state is the hard chain fluid system. In this way the dispersion term considers the attraction of chain molecules instead of that of unbounded segments, covering the influence neighboring segments of the same molecule on each other (de Loos, 2005). The different contributions to the residual Helmholtz energy in the PC-SAFT equation of state are summarized in Equation 18.

$\mathrm{A}^{\mathrm{res}}=\mathrm{A}^{\mathrm{hc}}+\mathrm{A}^{\mathrm{disp}}+\mathrm{A}^{\mathrm{assoc}}$

The association contribution to the Helmholtz energy accounts for specific short-range interactions, e.g. hydrogen bonding, dipole-dipole interactions.

For a detailed description of the PC-SAFT equation of state and its development, the reader is referred to literature (Gross and Sadowski, 2000, 2001).

\section{Results and discussion of calculations}

Vapor-liquid phase equilibria at high pressure

The vapor-liquid phase equilibria of styrene (Sty) $-\mathrm{CO}_{2}$ as well as of methyl methacrylate $(\mathrm{MMA})-\mathrm{CO}_{2}$ have been modeled with the Peng-Robinson equation of state. Table 1 lists the parameters used in the Peng-Robinson equation of state. The pure component parameters of Sty, MMA and $\mathrm{CO}_{2}$ are taken from Poling (2001); binary interaction parameters are taken from Suppes and McHugh (1989) and Uzun et al. (2005). 
Table 1 Peng-Robinson parameters as used for calculations. Pure component parameters are taken from Poling et al. (2001), binary interaction parameter $\mathrm{k}_{\mathrm{ij}}$ taken from Suppes and McHugh (1989) and Uzun et al. (2005)

\begin{tabular}{c|c|c|c}
\hline parameter & Sty & MMA & $\mathrm{CO}_{2}$ \\
\hline \hline $\mathrm{T}_{\mathrm{c}}[\mathrm{K}]$ & 647.05 & 563.95 & 304.25 \\
\hline $\mathrm{P}_{\mathrm{c}}\left[10^{5} \mathrm{~Pa}\right]$ & 39.9 & 36.8 & 73.8 \\
\hline$\omega[-]$ & 0.257 & 0.317 & 0.225 \\
\hline
\end{tabular}

\begin{tabular}{c|c}
\hline $\mathrm{k}_{\mathrm{Sty}-\mathrm{CO}_{2}}$ & 0.046 \\
\hline
\end{tabular} \begin{tabular}{ll|}
$\mathrm{k}_{\mathrm{MMA}-\mathrm{CO}_{2}}$ & 0.033 \\
\hline
\end{tabular}

Experimental data for the binary systems Sty $-\mathrm{CO}_{2}$ and $\mathrm{MMA}-\mathrm{CO}_{2}$ are available in literature (Suppes and McHugh, 1989, Uzun et al., 2005). These data have been used to model the respective binary systems. Figure 1 shows the results of the modeling of the experimental liquid-vapor data for Sty- $\mathrm{CO}_{2}$ (Suppes and McHugh, 1989) as well as for MMA$\mathrm{CO}_{2}$ (Uzun et al., 2005).
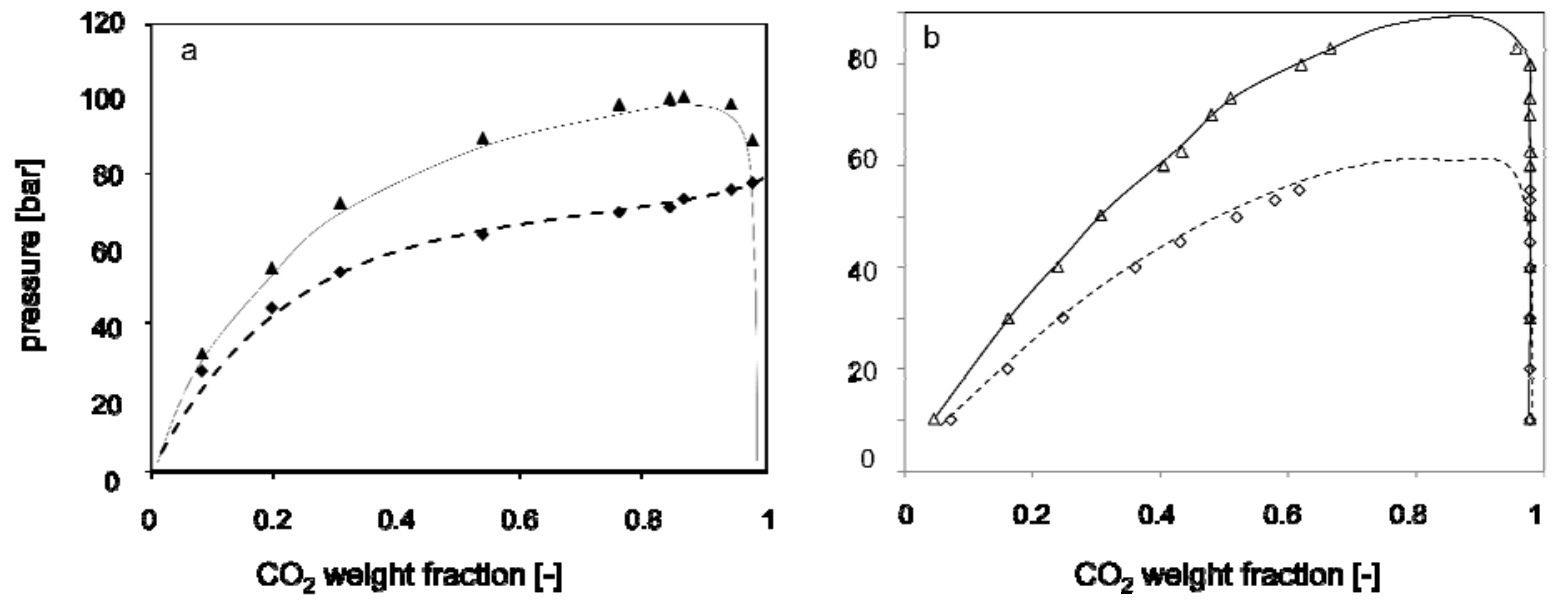

Figure 1 Phase equilibrium data of the binary system Styrene- $\mathrm{CO}_{2}(\mathrm{a})$. Symbols represent experimental data taken from Suppes and McHugh $(1989) \diamond 35^{\circ} \mathrm{C}, \Delta 55^{\circ} \mathrm{C}$. Lines represent calculations with the Peng-Robinson equation of state, $-35^{\circ} \mathrm{C},---55^{\circ} \mathrm{C} ; \mathrm{k}_{\mathrm{Sty}^{-} \mathrm{CO}_{2}}=0.046$ (Suppes and McHugh, 1989); $\mathrm{MMA}-\mathrm{CO}_{2}$ (b). Symbols represent experimental data taken from Uzun et al. (2005), $\diamond 35^{\circ} \mathrm{C}, \Delta 60^{\circ} \mathrm{C}$. Lines represent calculations with the Peng-Robinson equation of state, $\cdots \cdots \cdots \cdots \cdot 35^{\circ} \mathrm{C},-60^{\circ} \mathrm{C} ; \mathrm{k}_{\mathrm{MMA}^{-\mathrm{CO}_{2}}}=0.033$ (Uzun et al., 2005).

The Peng-Robinson equation of state applies well in modeling liquid-vapor phase equilibria at high pressure. Knowledge of the phase behavior of the binary systems determines the 
lowest possible operating pressure at a chosen constant temperature (or vice versa) to prevent phase separation of $\mathrm{CO}_{2}$ and monomer during the extraction process. On the other hand it is noticed small changes in temperature and pressure should allow separation of $\mathrm{CO}_{2}$ and monomer after the extraction process.

\section{Phase equilibria in polymer solutions}

Phase equilibrium of the ternary systems polystyrene (PS) - styrene (Sty) - $\mathrm{CO}_{2}$ and polymethyl methacrylate (PMMA) - methyl methacrylate (MMA) $-\mathrm{CO}_{2}$ has been modeled with the Perturbed Chain - Statistical Associated Fluid Theory (PC-SAFT) equation of state using the VLXE software of Laursen (2003). Table 2 shows the parameters used in the phase behavior calculations with the PC-SAFT equation of state. The pure component parameters were taken from the database of the VLXE software. The binary interaction parameters in the PS - Sty $-\mathrm{CO}_{2}$ system were fitted to the cloud-point curve of the respective binary systems (Suppes and McHugh, 1989, Wissinger and Paulaitis, 1991). The binary interaction coefficients in the PMMA - MMA $-\mathrm{CO}_{2}$ system were taken from literature (Görnert and Sadowski, 2008, Rajendran et al., 2005, Lora and McHugh, 1999).

Table 2 PC-SAFT parameters as used for calculations

\begin{tabular}{c|c|c|c|c|c}
\hline parameter & PS & Sty & PMMA & MMA & $\mathrm{CO}_{2}$ \\
\hline \hline$\epsilon / k[K]$ & 267 & 295.98 & 245 & 265.69 & 169.21 \\
\hline$\sigma[\AA]$ & 4.107 & 3.712 & 3.6 & 3.624 & 2.785 \\
\hline $\mathrm{m}[-]$ & $\mathrm{M}_{\mathrm{w}} * 0.019$ & 3.08 & $\mathrm{M}_{\mathrm{w}} * 0.019$ & 3.06 & 2.07 \\
\hline
\end{tabular}

\begin{tabular}{c|l}
\hline $\mathrm{k}_{\mathrm{Sty}-\mathrm{PS}}$ & 0 \\
\hline $\mathrm{k}_{\mathrm{PS}-\mathrm{CO}_{2}}$ & 0.14 \\
\hline $\mathrm{k}_{\mathrm{Sty}-\mathrm{CO}_{2}}$ & 0.1 \\
\hline
\end{tabular}

\begin{tabular}{c|l}
\hline $\mathrm{k}_{\text {MMA-PMMA }}$ & -0.02 \\
\hline $\mathrm{k}_{\mathrm{PMMA}-\mathrm{CO}_{2}}$ & $-4.67 * 10^{-3}+2.667 * 10^{-4} * \mathrm{~T}[\mathrm{~K}]$ \\
\hline $\mathrm{k}_{\text {MMA-CO}}$ & -0.01 \\
\hline
\end{tabular}

Note that the pure component parameters in Table 2, for both PS and PMMA, are parameters for pretreated polymers, i.e. PS and PMMA have been annealed above their glass transition temperature to remove any influence of the polymerization method as well as of contaminants. In the present study of the extraction of residual monomer from polymer 
(latex) products, the polymers have not been pretreated in any way. It is very probable that pretreatment of the polymers changes physical interactions in comparison with untreated polymers.

Figure 2 shows the calculated phase behavior of the ternary system PS $(100 \mathrm{~kg} / \mathrm{mol})$ - Sty $\mathrm{CO}_{2}$ at $18{ }^{\circ} \mathrm{C}$ for the pressures of 50 and 100 bar, respectively. The solid lines (phase boundary) as well as the dashed lines (tie lines) have been calculated with the PC-SAFT equation of state using the parameters listed in Table 2.

a: $P=50$ bar

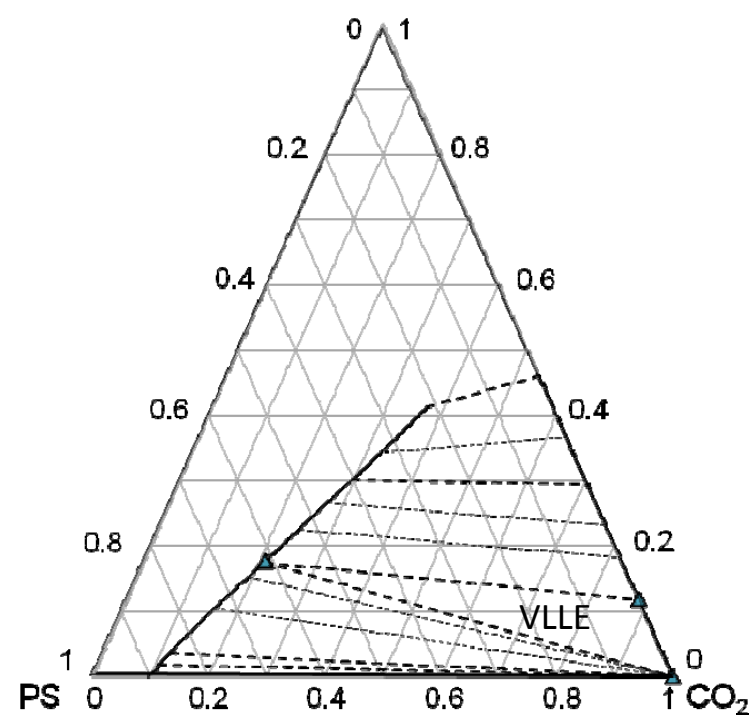

b: $P=100$ bar sty

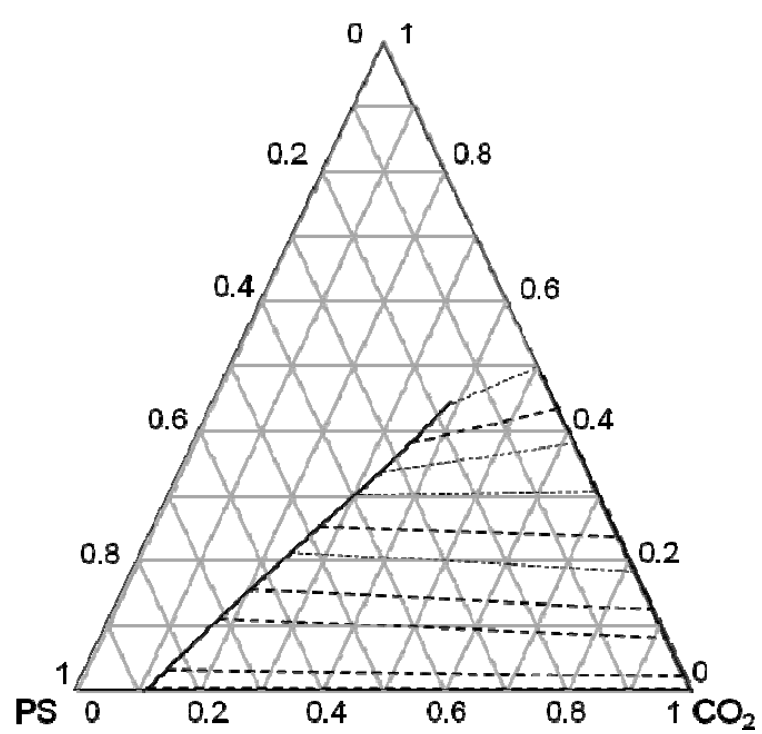

Figure 2 Phase behavior of the system PS $\left(\mathrm{M}_{\mathrm{w}}=100 \mathrm{~kg} / \mathrm{mol}\right)-\mathrm{Sty}-\mathrm{CO}_{2}$ at $18{ }^{\circ} \mathrm{C}$, calculated with the PC-SAFT equation of state, concentrations are given in mass fractions. Solid lines represent phase boundaries, dashed lines represent tie lines; $\mathrm{k}_{\mathrm{Sty}^{-\mathrm{CO}_{2}}}=0.1$; $\mathrm{k}_{\mathrm{Sty}-\mathrm{PS}}=0 ; \mathrm{k}_{\mathrm{CO}_{2}-\mathrm{PS}}=0.14$. Triangles represent the borders of the VLLE region. a: 50 bar, b: 100 bar.

Figure $2 a$ illustrates a homogeneous system at low $\mathrm{CO}_{2}$ mass fractions at 50 bar. For higher $\mathrm{CO}_{2}$ mass fractions the phase boundary is reached. A three phase region is formed due to the vapor-liquid equilibrium between Sty and $\mathrm{CO}_{2}$ at $18{ }^{\circ} \mathrm{C}$ and 50 bar, as mentioned in the previous section. The triangles in Figure 2a represent the borders of the vapor-liquid-liquid equilibrium (VLLE) region. In the VLLE region a $\mathrm{CO}_{2}$ vapor phase containing very small 
amounts of Sty, is in equilibrium with a polymer rich liquid phase and a polymer lean liquid phase. Increasing the pressure to 100 bar, as shown in Figure $2 \mathrm{~b}$, a supercritical Sty- $\mathrm{CO}_{2}$ mixture is formed. No three phase region exists anymore. $\mathrm{A} \mathrm{CO}_{2}$ rich vapor phase is in equilibrium with a polymer rich phase. Note that the slopes of the tie lines are more positive towards $\mathrm{CO}_{2}$ at the higher pressure of 100 bar, indicating that more Sty dissolves in $\mathrm{CO}_{2}$ compared to the system at the 50 bar. Choosing the operating conditions for the extraction of residual monomer from polymer (latex) products with high pressure $\mathrm{CO}_{2}$, the binary phase behavior of $\mathrm{CO}_{2}$ and monomer must be taken into account. A phase separation between monomer and $\mathrm{CO}_{2}$ should be avoided.

Figure 3 shows the influence of temperature at a chosen constant pressure of 100 bar on the phase behavior of the PS $(100 \mathrm{~kg} / \mathrm{mol})-$ Sty $-\mathrm{CO}_{2}$ system.

a: $35^{\circ} \mathrm{C}$

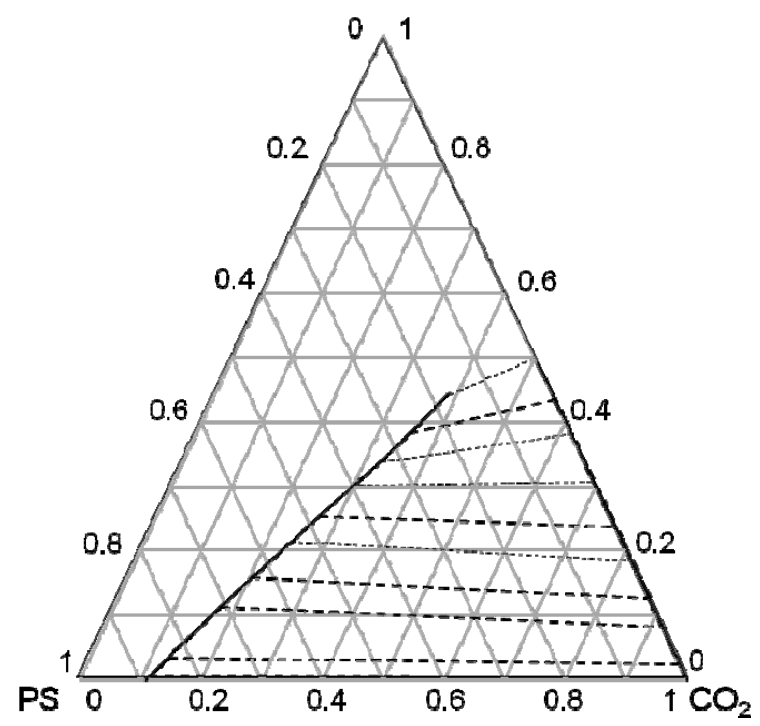

b: $35^{\circ} \mathrm{C} \quad$ Sty

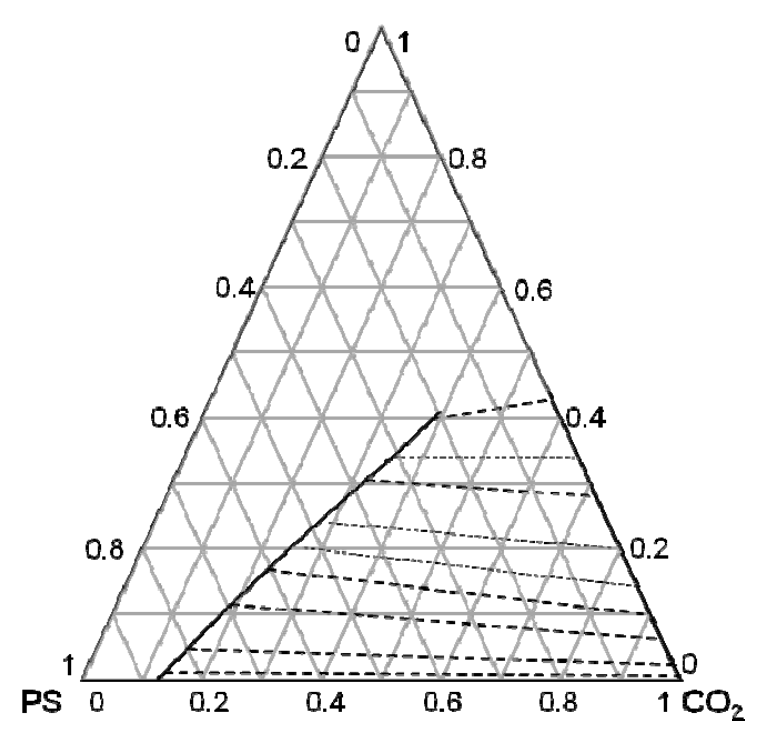

Figure 3 Phase behavior of the system PS $(100 \mathrm{~kg} / \mathrm{mol})-$ Sty $-\mathrm{CO}_{2}$ at 100 bar, calculated with the PC-SAFT equation of state, pictures are based on mass fractions. Solid lines represent phase boundaries, dashed lines represent tie lines; $\mathrm{k}_{\mathrm{Sty}^{-\mathrm{CO}_{2}}}=0.1$; $\mathrm{k}_{\mathrm{Sty}-\mathrm{PS}}=0$; $\mathrm{k}_{\mathrm{CO}_{2}-\mathrm{PS}}=0.14$. a: $18^{\circ} \mathrm{C} ; \mathrm{b}: 35^{\circ} \mathrm{C}$. 
For the ternary system at a temperature of $18{ }^{\circ} \mathrm{C}$ as well as at $35{ }^{\circ} \mathrm{C}$ at 100 bar, no three phase regions appear in the phase diagram. For higher $\mathrm{CO}_{2}$ mass fractions only a two phase region exist where the $\mathrm{CO}_{2}$ rich vapor phase is in equilibrium with a polymer rich liquid phase. Phase separation between Sty and $\mathrm{CO}_{2}$ appears at different compositions of monomer and $\mathrm{CO}_{2}$ on increasing the temperature. Notice the slopes of the tie lines become more positive towards the polymer rich phase. Moreover, with increasing temperature the polymer rich phase contains more Sty, while the $\mathrm{CO}_{2}$ rich phase contains less Sty. At constant pressure $\mathrm{CO}_{2}$ extracts more Sty at a lower temperature than at higher temperatures. Note that at a low temperature and a high pressure the density of $\mathrm{CO}_{2}$ is higher than at a high temperature and a high pressure.

Partitioning of Sty between $\mathrm{CO}_{2}$-swollen PS and $\mathrm{CO}_{2}$ has been calculated based on the monomer concentrations in both phases as predicted with the PC-SAFT equation of state. The partition coefficient is defined in Equation 19.

$\mathrm{K}_{\mathrm{mon}}=\frac{\mathrm{C}_{\mathrm{mon}}^{\mathrm{CO}_{2}}}{\mathrm{C}_{\mathrm{mon}}^{\text {pol }}}\left[\frac{\mathrm{kg} \text { polymer }}{\mathrm{kg} \mathrm{CO}_{2}}\right]$

The extraction of residual monomer in polymer products with high pressure $\mathrm{CO}_{2}$ deals with very low monomer concentrations, i.e. less than $10^{4}$ parts per million (ppm). In Table 3 calculated partition coefficients for distribution of styrene between $\mathrm{CO}_{2}$-swollen PS and $\mathrm{CO}_{2}$ for various temperatures and pressures at low monomer concentrations in the $\mathrm{CO}_{2}$-swollen polymer phase are collected. Partition coefficients were calculated with PC-SAFT and physical constants given in Table 2 .

Table 3 Partition coefficient of Sty between $\mathrm{CO}_{2}$-swollen PS $(100 \mathrm{~kg} / \mathrm{mol})$ and $\mathrm{CO}_{2}$, for a concentration of Sty in PS below $10^{4} \mathrm{ppm}$

\begin{tabular}{c|c|c}
\hline Temperature $\left[{ }^{\circ} \mathrm{C}\right]$ & Pressure $[$ bar $]$ & Partition coefficient $\left[\frac{\mathrm{kg} \mathrm{PS}}{\mathrm{kg} \mathrm{CO}}\right]^{*}$ \\
\hline \hline 18 & 50 & 0.007 \\
\hline 18 & 100 & 0.62 \\
\hline 18 & 200 & 0.75 \\
\hline 35 & 100 & 0.42 \\
\hline 35 & 200 & 0.64 \\
\hline 40 & 100 & 0.34 \\
\hline
\end{tabular}

see equation 20 
The results in Table 3 demonstrate that increasing pressure at a constant temperature leads to higher values of the partition coefficient. The $\mathrm{CO}_{2}$ density increases upon pressurizing the system, dissolving more monomer. The results in Table 3 also demonstrate that the partition coefficient deceases upon increasing temperature at a constant pressure. Due to the decreasing $\mathrm{CO}_{2}$ density at higher temperatures, the partition coefficient also decreases as less monomer is dissolved in $\mathrm{CO}_{2}$. An interesting issue is the partition coefficient at $18{ }^{\circ} \mathrm{C}$ and 100 bar is almost equal to the partition coefficient at $35^{\circ} \mathrm{C}$ and 200 bar. For these two conditions the $\mathrm{CO}_{2}$ density is approximately equal (i.e. $800 \mathrm{~kg} / \mathrm{m}^{3}$ ). The partition coefficient therefore strongly depends on the temperature and pressure of the system, due to the changes in the $\mathrm{CO}_{2}$ density. The partition coefficient of Sty at $18{ }^{\circ} \mathrm{C}$ and 50 bar is very low due to the phase separation between Sty and $\mathrm{CO}_{2}$, as explained earlier.

Similar calculations have been performed predicting the phase behavior of the ternary system PMMA - MMA - $\mathrm{CO}_{2}$ with the PC-SAFT equation of state using the parameters listed in Table 2. Table 4 summarizes the results of the calculations of the partition coefficient of MMA between $\mathrm{CO}_{2}$-swollen PMMA and $\mathrm{CO}_{2}$ at various temperatures and pressures.

Table 4 Partition coefficients of MMA between $\mathrm{CO}_{2}$-swollen PMMA (100 kg/mol) and $\mathrm{CO}_{2}$, for a concentration of MMA in PMMA below $10^{4} \mathrm{ppm}$

\begin{tabular}{c|c|c}
\hline Temperature $\left[{ }^{\circ} \mathrm{C}\right]$ & Pressure $[$ bar $]$ & Partition coefficient $\left[\frac{\mathrm{kg} \mathrm{PMMA}}{\mathrm{kg} \mathrm{CO}}\right]^{*}$ \\
\hline \hline 35 & 50 & 0.014 \\
\hline 35 & 100 & 2.1 \\
\hline 35 & 200 & 4 \\
\hline 40 & 100 & 1.7 \\
\hline 50 & 100 & 1.5 \\
\hline See equation 20 &
\end{tabular}

For the system PMMA - MMA - $\mathrm{CO}_{2}$ the partition coefficient also increases when the pressure increases at a constant temperature $\left(\mathrm{CO}_{2}\right.$ density increases $)$, and decreases when the temperature increases at a constant pressure $\left(\mathrm{CO}_{2}\right.$ density decreases). Note that at 35 ${ }^{\circ} \mathrm{C}$ and 50 bar MMA and $\mathrm{CO}_{2}$ do not form a supercritical mixture which results in a very low partition coefficient. 
The Gibbs-Helmholtz relation indicates the decrease of the partition coefficient with increasing temperature when $\Delta \Delta \mathrm{H}_{\text {solution }}<0$. The Gibbs-Helmholtz relation is expressed in Equation 21. The partition coefficient is written in terms of Gibbs free energies of solution, Equation 20.

$\mathrm{K}_{\text {mon }}=\mathrm{e}^{\frac{-\Delta \Delta \mathrm{G}_{\text {solution }}}{\mathrm{R} \mathrm{T}}}$ with $\Delta \Delta \mathrm{G}_{\text {solution }}=\Delta \Delta \mathrm{G}_{\text {solution in } \mathrm{CO}_{2}}-\Delta \Delta \mathrm{G}_{\text {solution in } \mathrm{CO}_{2} \text { swollen polymer }}$

When the heats of solution are independent of temperature, Equation 21 holds, see also Chapter 3.

$\ln \frac{\mathrm{K}_{\mathrm{mon}}^{\mathrm{T}_{2}}}{\mathrm{~K}_{\mathrm{mon}}^{\mathrm{T}_{1}}}=-\frac{\Delta \Delta \mathrm{H}_{\text {solution }}}{\mathrm{R}} *\left[\frac{1}{\mathrm{~T}_{2}}-\frac{1}{\mathrm{~T}_{1}}\right]$

Figure 4 illustrates the relation between the calculated partition coefficient and the temperature at 100 bar for the ternary systems PS - Sty $-\mathrm{CO}_{2}$ (solid symbols) and PMMA $\mathrm{MMA}-\mathrm{CO}_{2}$ (open symbols).
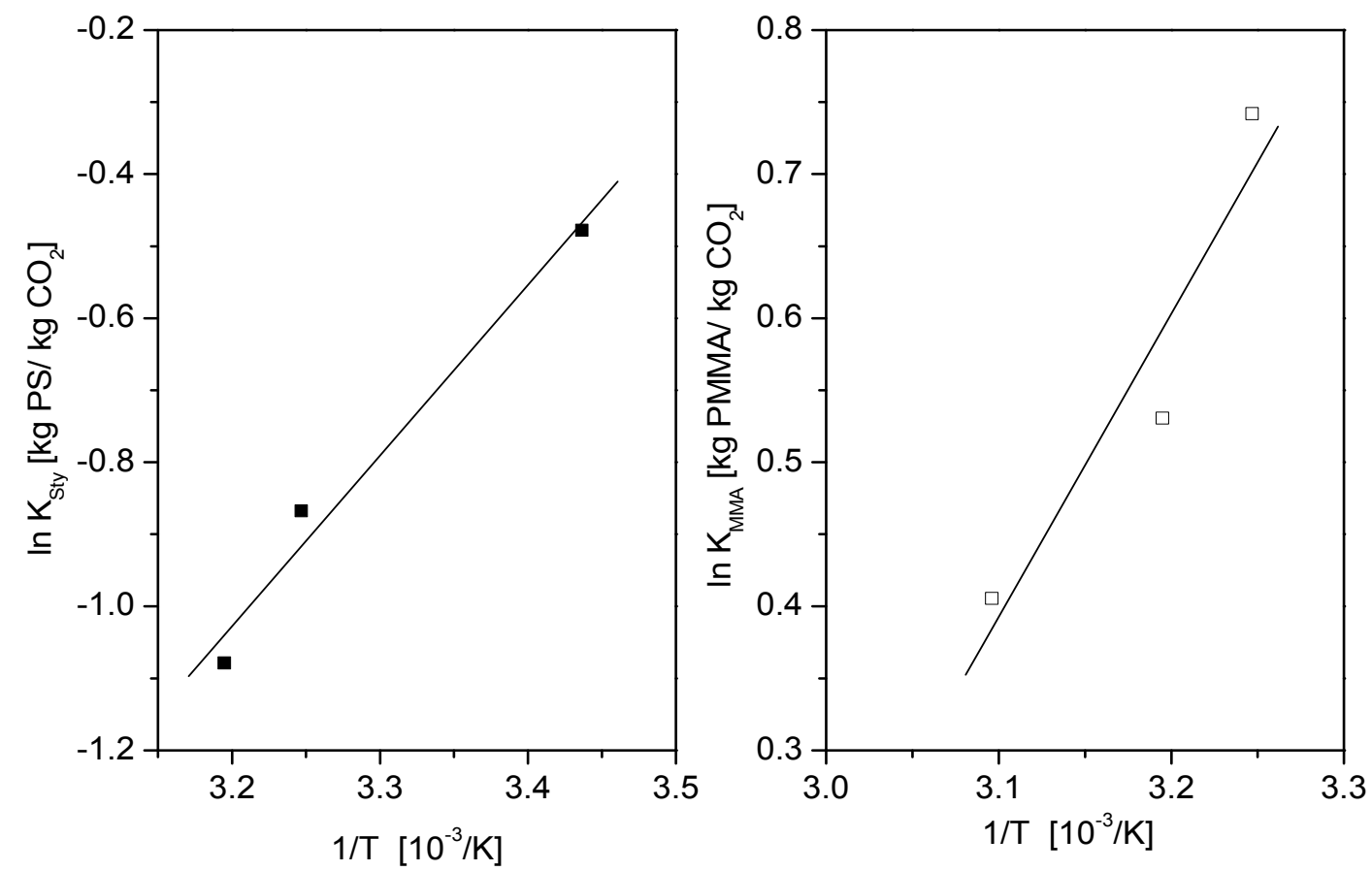

Figure 4 Partition coefficient of monomer between $\mathrm{CO}_{2}$-swollen polymer and $\mathrm{CO}_{2}$ at 100 bar in function of the temperature. Solid symbols represent styrene, open symbols represent MMA. Data points are fitted to $\ln \mathrm{K}_{\mathrm{mon}}^{\mathrm{T}}=-\frac{\Delta \Delta \mathrm{H}_{\text {solution }}}{\mathrm{R}} *\left[\frac{1}{\mathrm{~T}}\right]+$ constant with $\mathrm{K}_{\text {mon }}=\frac{\mathrm{C}_{\text {mon }}^{\mathrm{CO}_{2}}}{C_{\text {mon }}^{\text {pol }}}$, based on weight fractions. 
The difference in heat of solution of Sty dissolved in $\mathrm{CO}_{2}$ and the heat of solution of Sty dissolved in PS swollen with $\mathrm{CO}_{2}$ at $40{ }^{\circ} \mathrm{C}$ and $18{ }^{\circ} \mathrm{C}$ is $\sim 21 \mathrm{~kJ} / \mathrm{mol}$, see Equation 21 . The difference in heat of solution of MMA dissolved in $\mathrm{CO}_{2}$ and the heat of solution of MMA dissolved in $\mathrm{CO}_{2}$ swollen PMMA at $50{ }^{\circ} \mathrm{C}$ and $35^{\circ} \mathrm{C}$ is $\sim 19 \mathrm{~kJ} / \mathrm{mol}$.

Note that the calculated partition coefficients for distribution of Sty between $\mathrm{CO}_{2}$ swollen PS and $\mathrm{CO}_{2}$ are generally lower than the partition coefficients for the distribution of MMA between $\mathrm{CO}_{2}$ swollen PMMA and $\mathrm{CO}_{2}$. This difference suggests that the molecular interactions between Sty and $(\mathrm{sc}) \mathrm{CO}_{2}$ are weaker than the $\mathrm{MMA}$ and $(\mathrm{sc}) \mathrm{CO}_{2}$ interactions, resulting in a lower affinity of Sty in (sc) $\mathrm{CO}_{2}$. Kazarian et al. (1996a) studied the specific interactions of $\mathrm{CO}_{2}$ with monomers to gain insight into interactions of $\mathrm{CO}_{2}$ with polymers. With Fourier transform infrared (FTIR) spectroscopy, Kazarian and coworkers (1996a) demonstrated that $\mathrm{CO}_{2}$ acts as a Lewis acid. An electron donor-acceptor complex between the carbonyl oxygen atom of MMA and the $\mathrm{CO}_{2}$ carbon atom is formed, increasing solubility. For styrene there are no specific interactions with $\mathrm{CO}_{2}$ as for $\mathrm{MMA}$ and $\mathrm{CO}_{2}$. Similar observations have also been reported by Kazarian et al. (1996 b) and Shieh and Liu (2002).

\section{Concluding remarks}

The phase behavior of the binary systems Sty- $\mathrm{CO}_{2}$ and $\mathrm{MMA}-\mathrm{CO}_{2}$ has been modeled with the Peng-Robinson equation of state. The calculated pressures approach the experimentally determined pressures (taken from literature) very well. The ternary systems PS - Sty $-\mathrm{CO}_{2}$ and PMMA - MMA - $\mathrm{CO}_{2}$ have been modeled with the Perturbed Chain - Statistical Associated Fluid Theory at various temperatures between $18{ }^{\circ} \mathrm{C}$ and $50{ }^{\circ} \mathrm{C}$ at various pressures between 50 bar and 200 bar. Monomer partitioning between the $\mathrm{CO}_{2}$ swollen polymer phase and $\mathrm{CO}_{2}$ strongly depends on the temperature and pressure. The partition coefficients for distribution of Sty between $\mathrm{CO}_{2}$ swollen PS are generally lower than the partition coefficients for the distribution of MMA between $\mathrm{CO}_{2}$ swollen PMMA and $\mathrm{CO}_{2}$. 


\section{References}

W. G. Chapman, K. E. Gubbins, G. Jackson, M. Radosz, "SAFT: Equation of state model for associating fluids", Fluid Phase Equilib., 1989, 52, 31-38

M. Görnert, G. Sadowski, "Phase-equilibrium measurement and modeling of the PMMA/MMA/carbon dioxide ternary system", J. of Supercrit. Fluids, 2008, 46, 218-225

J. Gross, G. Sadowski, "Application of perturbation theory to a hard-chain reference fluid: an equation of state for square-well chains", Fluid Phase Equilibria, 2000, 168, 183-199

J. Gross, G. Sadowski, "Perturbed-Chain SAFT: An equation of state based on a perturbation theory for chain molecules", Ind. Eng. Chem. Res., 2001, 40, 1244-1260

S. J. Han, H. M. Lin, K. C. Chao, "Vapor-liquid equilibrium of molecular fluid mixtures by equation of state", Chem. Eng. Sci., 1988, 43, 2327

S. G. Kazarian, C. A. Eckert, J. C. Meredith, K. P. Johnston, J. M. Seminario, "Quantitative equilibrium constants between $\mathrm{CO}_{2}$ and Lewis bases from FTIR spectroscopy", J. Phys. Chem., 1996 (a) , 100, 10837-10848

S. G. Kazarian, M. F. Vincent, F. V. Bright, C. L. Liotta, C. A. Eckert, "Specific intermolecular interaction of carbon dioxide with polymers", J. Am. Chem. Soc., 1996 (b), 118, 1729-1736

T. Laursen, Technical University of Denmark, 2003, http://www.vlxe.com

T. W. de Loos, "Polymer thermodynamics", in "Handbook of polymer reaction engineering", T. Meyer, J. Keurentjes, Eds., 2005, Wiley-VCH, Weinheim

M. Lora, M. A. McHugh, "Phase behavior and modeling of the poly(methyl methacrylate)$\mathrm{CO}_{2}$-methyl methacrylate system", Fluid Phase Equilibria, 1999, 285-297

P. M. Mathias, H. C. Klotz, J. M. Prausnitz, "Equation-of-state mixing rules for multicomponent mixtures: the problem of invariance", Fluid phase equilibria, 1991, 67, 31

M. L. Michelsen, H. Kistenmacher, "On composition-dependent interaction coefficients", Fluid Phase Equilibria, 1990, 58, 229

A. Z. Panagiotopoulos, R. C. Reid, "High-pressure phase equilibria in ternary fluid mixtures with a supercritical component”, ACS Div. Chem., Prep., 1985, 30, 46

D. Peng, D. B. Robinson, "A new two-constant equation of state", Ind. Eng. Chem. Fund., 1976, 15, 59-64

B. E. Poling, J. M. Prausnitz, J. P. O'Connell, "The properties of gases and liquids", $5^{\text {th }}$ ed., 2001, McGraw-Hill Companies, Inc., USA

J. M. Prausnitz, J. Gmehling, "vt-Hochschulkurs III: Thermische verfahrenstechnik phasengleichgewichte", Thermische Verfahrenstechnik, 1979, 13, 3

A. Rajendran, B. Bonavoglia, N. Forrer, G. Storti, M. Mazotti, M. Mordibelli, "Simultaneous measurement of swelling and sorption in a supercritical $\mathrm{CO}_{2}$-poly(methyl methacrylate) system", Ind. Eng. Chem. Res., 2005, 44, 2549-2560 
G. Sadowksi, "Thermodynamik der polymerlösungen", Habilitationsschrift, Technischen Universität Berlin, 2000, 2003, Shaker, Aachen

I. C. Sanchez, R. H. Lacombe, "An elementary molecular theory of classical fluids. Pure fluids”, J. Phys. Chem., 1976, 80, 2352-2362

Y.-T. Shieh, K.-H. Liu, "Solubility of $\mathrm{CO}_{2}$ in glassy PMMA and PS over a wide pressure range: the effect of the carbonyl groups", J. Polym. Res., 2002, 9, 107-113

J. M. Smith, H. C. Van Ness, M. M. Abbot, "Introduction to chemical engineering thermodynamics", 2001,

R. Streyjek, J. H. Vera, "A cubic equation of state for accurate vapour-liquid equilibria calculations", Can. J. Chem. Eng., 1986, 64, 820

G. J. Suppes, M. McHugh, "Phase behavior of the carbon dioxide-styrene system", J. Chem. Eng. Dat., 1989, 34, 310-312

N. I. Uzun, M. Akgün, N. Baran, S. Deniz, S. Dinçer, "Methyl methacrylate plus carbon dioxide phase equilbria at high pressures", J. Chem. Eng. Dat., 2005, 50, 4, 1144-1147

R. G. Wissinger, M. E. Paulaitis, "Molecular thermodynamic model for sorption and swelling in glassy polymer- $\mathrm{CO}_{2}$ systems at elevated pressures", Ind. Eng. Chem. Res., 1991, 30, 5, 842-851

D. S. H. Wong, S. I. Sandler, "A theoretically correct mixing rule for cubic equations of state", AlChE Journal, 1992, 38, 671 


\section{Appendix A}

The molar Gibbs free energy of mixing for an ideal system is the Gibbs energy of mixing per unit amount of mixture formed, defined as Equation A.1 (DeVoe, 2001)

$G_{m}=H_{m}-T * S_{m}$

The enthalpy and entropy of 1 mole ideal mixture are written as, Equations A.2 and A.3.

$H_{m}=\sum_{i} x_{i} * H_{i}^{\circ}$

$S_{m}=\sum_{i} x_{i} *\left(S_{i}^{\circ}-R * \ln x_{i}\right)$

For an ideal solution $H_{m}=0$, so

$\Delta_{m i x} G_{m}=-T * \Delta_{m i x} S_{m}$

The molar Gibbs free energy of mixing in an ideal system then is, Equation A.5.

$\Delta_{m i x} G_{m}=R T * \sum_{i} x_{i} * \ln x_{i}$

For mixing pure substances to form a non-ideal solution, the deviation from an ideal solution is expressed in terms of excess molar mixing quantities at the same conditions of pressure, temperature and composition, see Equation A.6.

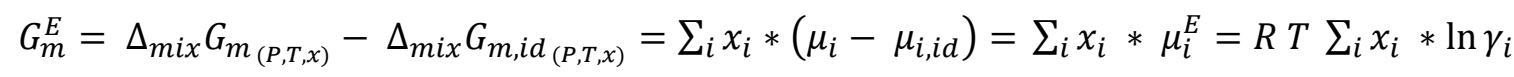

Note that the relation between the excess molar Gibbs energy and the activity coefficient follows from Equation A.7.

$\mu_{i}^{E}=\mu_{i}-\mu_{i, i d}=\left(\mu_{i}-\mu_{i}^{\circ}\right)-\left(\mu_{i, i d}-\mu_{i}^{\circ}\right)=R T \ln \frac{\hat{f}_{i}}{f_{i}^{\circ}}-R T \ln \frac{x_{i} * f_{i}^{\circ}}{f_{i}^{\circ}}$

$=R T \ln \frac{\hat{f}_{i}}{x_{i} * f_{i}^{\circ}}=R T \ln \gamma_{i}$ 




\title{
Chapter 3
}

\section{Experimental determination of the partition coefficient of monomers over polymer and supercritical carbon dioxide}

\begin{abstract}
The efficiency of high pressure carbon dioxide to reduce residual monomer in polymer products strongly depends on the monomer partitioning over the various phases involved in the separation process.
\end{abstract}

Phase behavior of the methyl methacrylate-carbon dioxide and styrene-carbon dioxide binary systems has been studied in a high-pressure variable volume optical cell and in a closed high pressure autoclave. The Peng-Robinson equation of state has been used to describe the pressure as a function of the composition in terms of of monomer and carbon dioxide. Monomer partitioning between the polymethyl methacrylate or polystyrene phase and the carbon dioxide phase has been determined experimentally for a range of pressures and temperatures in a high pressure autoclave.

\section{Introduction}

Extraction with supercritical or high pressure carbon dioxide $\left((\mathrm{sc}) \mathrm{CO}_{2}\right)$ is an interesting alternative to e.g. steam stripping to reduce the residual monomer level in polymer (latex) products. Knowledge of the phase behavior of the system monomer/polymer (latex)/(sc) $\mathrm{CO}_{2}$ as a function of various operating conditions is a prerequisite for process design.

Several authors already reported the results of phase behavior measurements of methyl methacrylate (MMA)-(sc) $\mathrm{CO}_{2}$ (Lora and McHugh, 1999, Uzun et al., 2005, Zwolak et al., 2005, da Silva et al., 2007) and of styrene (Sty)-(sc) $\mathrm{CO}_{2}$ (Suppes and McHugh, 1989, Tan et al., 1991, Akgun et al., 2004, Zhang et al., 2005) for a range of temperatures and 
concentrations. In the present work experimental phase equilibria of the binary systems MMA-(sc) $\mathrm{CO}_{2}$ and Sty-(sc) $\mathrm{CO}_{2}$ at 35,45 and $60{ }^{\circ} \mathrm{C}$ have been collected. Cloud-point measurements were performed using a high pressure variable volume optical cell. The concentrations of the coexisting phases were determined in a high-pressure autoclave with an online sampling system.

Phase behavior of the ternary system polystyrene (PS)-Sty-(sc) $\mathrm{CO}_{2}$, for high monomer concentrations in the polymer phase, was studied by Görnert and Sadowski (2007) and Wu et al. (2002); polymethyl methacrylate (PMMA)-MMA-(sc) $\mathrm{CO}_{2}$, for high monomer concentrations in the polymer phase, was also investigated by Görnert and Sadowski (2008). Wu et al. (2002) reported experimentally determined distribution coefficients of styrene between the corresponding polymer (molecular weight $\sim 160 \mathrm{~kg} / \mathrm{mol}$ ) and the supercritical phase at $35{ }^{\circ} \mathrm{C}$ and $45{ }^{\circ} \mathrm{C}$ over the pressure range of $120-200$ bar. Görnert and Sadowski $(2007,2008)$ presented isothermal measurements at 65 and $80^{\circ} \mathrm{C}$ and pressures of 100 and 150 bar, for polymer samples having molecular weights of 6,18 or $10 \mathrm{~kg} / \mathrm{mol}$, for both the PS-Sty-(sc) $\mathrm{CO}_{2}$ and the PMMA-MMA-(sc) $\mathrm{CO}_{2}$ system. In the present work experiments were performed at 35,45 and $60{ }^{\circ} \mathrm{C}$ and 100,140 and 180 bar, for polymer samples with molecular weights above $10 \mathrm{~kg} / \mathrm{mol}$ and monomer concentrations in the polymer phase below $10^{4} \mathrm{ppm}$. The concentrations of MMA or Sty in the coexisting PS or PMMA and (sc) $\mathrm{CO}_{2}$ phases were measured by means of a high-pressure autoclave with an online sampling system.

The experimentally determined monomer partition coefficient for distribution of monomer between the $\mathrm{CO}_{2}$ swollen polymer and the $(\mathrm{sc}) \mathrm{CO}_{2}$ phase is used for design of extraction equipment for residual monomer reduction (see Chapter 5).

\section{Experimental}

\section{Materials}

Carbon dioxide $\left(\mathrm{CO}_{2}\right)$, grade 5.0 was obtained from Linde (The Netherlands). Prior to use $\mathrm{CO}_{2}$ was led over a Messer Oxisorb filter to remove oxygen and moisture. 
Styrene and methyl methacrylate monomer (purity $\geq 99 \%$ ), obtained from Aldrich, were stored under argon. Additional inhibitor (4-tert-butylcatechol) was added to obtain a concentration of 10 parts per million (ppm) to suppress polymerization during the experiment.

Polystyrene beads (diameter $1 \mathrm{~mm}$ and $5 \mathrm{~mm}$ ) and polymethyl methacrylate beads (diameter $0.5 \mathrm{~mm}$ ), both with a molecular mass of about $10^{5} \mathrm{~kg} / \mathrm{kmol}$, were kindly provided by BASF, Germany, and were used as received.

\section{High-pressure variable volume optical cell}

The high-pressure stainless steel optical cell (Sitec), see Figure 1, was temperature controlled by circulating oil in the heating jacket (PT100, $\pm 0.1{ }^{\circ} \mathrm{C}$ accuracy, TIC). The inner volume of the cell could be varied from $18 \mathrm{~mL}$ to $30 \mathrm{~mL}$ by means of a movable piston. The piston was driven by a hydraulic system. The pressure could be measured inside the cell, in direct contact with the mixture under investigation (HAEMI, circa 0.1 bar accuracy, PI). The maximum attainable temperature of the optical cell was $300{ }^{\circ} \mathrm{C}$. The maximum pressure allowed was 300 bar. A sapphire window allowed for observing $80 \%$ of the inner volume of the cell. $\mathrm{CO}_{2}$ was fed into the optical cell by a syringe pump (ISCO - model 260D, FP).

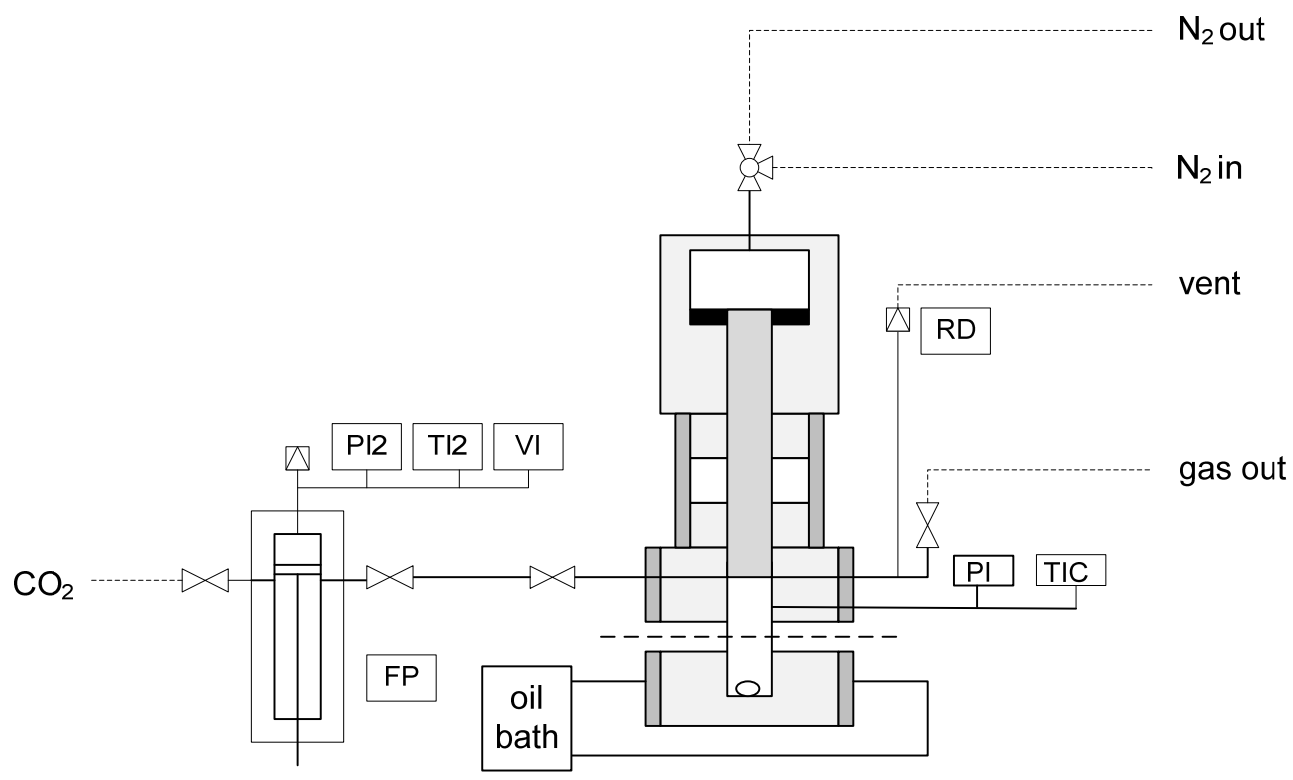

Figure 1 High-pressure variable volume cell. FP pump for liquid carbon dioxide, PI pressure indicator, TIC temperature indicator controller, VI volume indicator, RD rupture disk assembly. 
Cloud-point measurements - Monomer was weighed in into an empty cell, after which the cell was closed. The volume of the cell was decreased to its lowest value of $18 \mathrm{~mL} \mathrm{CO}$ gas was fed to the reactor at room temperature (pressure $\sim 30$ bar) and the mixture was then stirred with a small magnetic stirrer bar at the bottom of the optical cell. The cell content was heated to a temperature of $35{ }^{\circ} \mathrm{C}$ and consecutively $\mathrm{CO}_{2}$ was charged into the cell at a constant flow up to the pressure at which a homogeneous mixture was observed. These conditions were maintained for 10 minutes to allow for equilibration of the system. Starting from a homogeneous solution, the pressure was decreased by increasing the inner volume of the cell until the system starts to be turbid. After demixing, the pressure was increased until the system became homogeneous again. Decreasing and increasing the pressure of the system was repeated at least three times for one composition at the given temperature. Next, the temperature was increased to $45^{\circ} \mathrm{C}$. After equilibrium was reached, the same procedure of decreasing and increasing pressure was repeated for several times. Finally the temperature was increased to $60^{\circ} \mathrm{C}$ and the procedure as described above was repeated.

\section{High-pressure autoclave}

The stainless steel (AISI 304L) reactor (modified "Andorra" high pressure autoclave, Premex, De Heer B.V.) with a volume of $100 \mathrm{~mL}$, see Figure 2, was designed to withstand a maximum pressure of 300 bar at a maximum temperature of $300{ }^{\circ} \mathrm{C}$. The system was stirred with a magnetic stirrer head (Premex Maxonmotor, M) equipped with a Rushton-Turbine impeller. A small cylindrical basket, made of 2 layers of gauze with $400 \mathrm{~nm}$ pores crossed over each other, was attached to the stirrer. $\mathrm{CO}_{2}$ was fed into the reactor by a syringe pump (ISCO model 260D, FP). The amount of $\mathrm{CO}_{2}$ was calculated with the Modified Webb-BenedictRuben equation of state (MWBR EOS). Monomer was pumped into the autoclave by a high pressure pump for liquid chromatography (Shimadzu, HPLC). The temperature of the autoclave was controlled with an electrical circuit (3508 controller, Ordino Light, Pro Control B. V., TIC1). The pressure of the reactor was monitored with a calibrated pressure transducer (ATM, AE Sensors, accuracy circa 0.005 bar, PI1). Sampling from the top and bottom phase of the mixture in the autoclave was carried out using 2 independent Rolsi capillary sampler injectors (Mines ParisTech, R). The sampler-injectors were connected to 
the autoclave through $0.1 \mathrm{~mm}$ inner diameter capillaries and were in direct contact with the top and bottom phase respectively. The outlet of the capillaries was closed by a movable microstem operated by an electromagnet. When the electromagnet was activated, the outlet of the capillary was opened so that an accurate amount of the sample could flow into an expansion room. The expansion room was crossed by the carrier gas of a gas chromatograph (2010, Shimadzu), which swept the sample into the gas chromatograph column (Factor Four VF-5 ms fused silica column, isothermal method at $50{ }^{\circ} \mathrm{C}$ ). The sample volume could be accurately adjusted continuously from 0.1 to $1 \mu \mathrm{L}$ with an electronic timer. Due to the small sample size no pressure drop in the autoclave was observed. The expansion room of the sampler was heated independently from the autoclave to allow the samples to remain in the vapor state or to vaporize liquid samples.

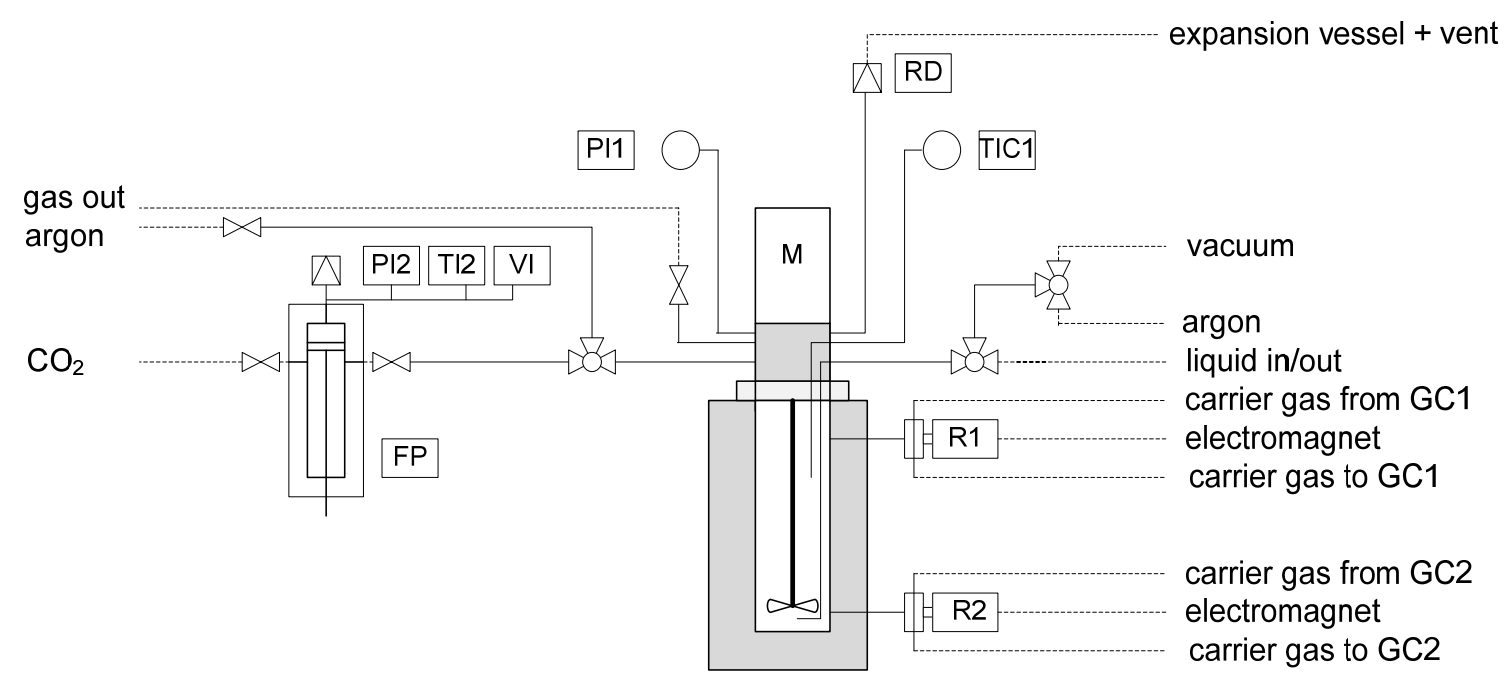

Figure 2 High-pressure autoclave. FP pump for liquid carbon dioxide, M magnetic stirring head, RD rupture disk assembly, R Rolsi, PI pressure indicator, TI temperature indicator, VI volume indicator, TIC temperature indicator controller.

Binary phase diagrams - The basket was removed from the stirrer. The autoclave was closed and gaseous $\mathrm{CO}_{2}$ was fed into the vessel at room temperature (pressure $\sim 30$ bar). Next, the stirrer was turned on with a revolution speed of $300 \mathrm{rpm}$ and the autoclave was heated to a temperature of 35 or $45^{\circ} \mathrm{C}$. When the desired temperature was reached, $\mathrm{CO}_{2}$ was charged into the autoclave at a constant flow up to a pressure of 90 bar. Consequently, a known volume of monomer was pumped into the autoclave while stirring. After 10 minutes 
stirring was stopped to allow phase separation in the vessel. Samples of the top and bottom phase were withdrawn every 12 minutes during 2 hours. Sampling was stopped and stirring was turned on again. Then an accurately known volume of monomer was added to the vessel content. After 10 minutes stirring was stopped again and sampling of top and bottom phase was started. This procedure was repeated several times.

Monomer partitioning over $\mathrm{CO}_{2}$ swollen polymer and $\mathrm{scCO}_{2}-$ An accurate amount of polymer was brought into the basket, an accurately known mass of monomer (10000 ppm or 100 ppm, based on polymer mass) was loaded into the autoclave. The autoclave was closed and the stirring was started with a speed of $150 \mathrm{rpm}$. Gaseous $\mathrm{CO}_{2}$ was fed into the vessel at room temperature (pressure $\sim 30$ bar) after which the vessel was heated to a temperature of 35,45 or $60{ }^{\circ} \mathrm{C}$. When the desired temperature was reached, $\mathrm{CO}_{2}$ was charged into the autoclave with a constant flow rate up to a pressure of 100 bar was reached. Samples of the vessel content, both top (R1) and bottom (R2), were withdrawn every 12 minutes. In preliminary trials it was observed that in about 2 hours phase equilibrium was reached (Appendix A). After at least 3 to 4 hours, sampling was stopped and the pressure of the autoclave was increased to 140 bar. Sampling was started again after the desired pressure was reached, also with a frequency of 1 sample per 12 minutes. The same procedure was repeated to increase the pressure of the autoclave to 180 bar.

\section{Calibration of gas chromatographic analysis}

Addition of an internal standard to the mixture under investigation will change the equilibrium pressure of the mixture. Therefore another method was chosen to calibrate the gas chromatograph. With a gas syringe an accurately known volume (known amount of moles) of $\mathrm{CO}_{2}$ was injected into the gas chromatograph. Injected volumes were in the range from 0.01 to $5 \mu \mathrm{L}$. For every volume the injection was repeated 6 to 10 times. The peak area of the chromatogram were plotted as a function of the amount of moles $\mathrm{CO}_{2}$ injected. The resulting plot was described with two separate equations with a $95 \%$ confidence window (see Appendix B). The same procedure using a $\mu \mathrm{L}$-sized syringe for liquids was followed to know the amount of moles of monomer in the sample. 


\section{Results and discussion}

\section{Phase behavior of the binary systems}

The vapor - liquid equilibrium data are determined for the Sty-(sc) $\mathrm{CO}_{2}$ and the MMA-(sc) $\mathrm{CO}_{2}$ system at 35,45 and $60{ }^{\circ} \mathrm{C}$ for monomer weight fractions in a range of 0.7 to 0.97 . The results of the cloud-point measurements are collected in Figures 3 and 4 (solid symbols). The gas phase compositions corresponding to the cloud-points are calculated with the PengRobinson equation of state (eos) (Appendix D). To confirm the reliability of the high-pressure autoclave, the concentrations of the coexisting monomer and $(\mathrm{sc}) \mathrm{CO}_{2}$ phase are measured at $35{ }^{\circ} \mathrm{C}$ for Sty-(sc) $\mathrm{CO}_{2}$ and at $45{ }^{\circ} \mathrm{C}$ for $\mathrm{MMA}-(\mathrm{sc}) \mathrm{CO}_{2}$ (half open symbols). The experiments have been repeated several times. The equilibrium compositions shown have been calculated from the average of the results of the repeated experiments at the same conditions. For comparison, literature data of the Sty-(sc) $\mathrm{CO}_{2}$ and $\mathrm{MMA}-(\mathrm{sc}) \mathrm{CO}_{2}$ systems are included in the respective figures (open symbols). 


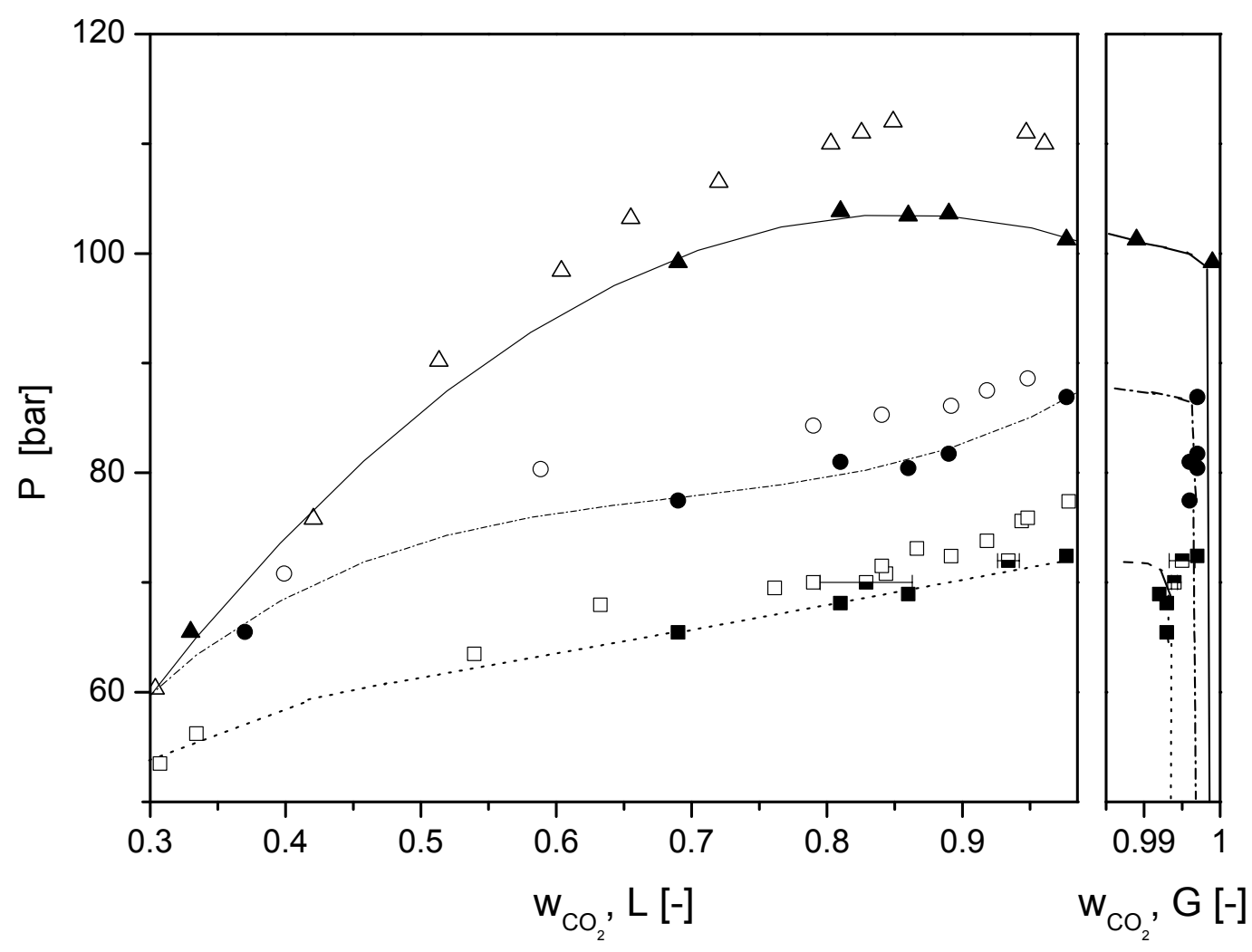

Figure 3 Cloud-point data of the Sty- $\mathrm{CO}_{2}$ binary system. $\square 35^{\circ} \mathrm{C}$, data collected from Suppes and McHugh (1989),Tan et al. (1991), Zhang et al. (2005), $=35^{\circ} \mathrm{C}$, this work (solid symbols in the liquid $(L)$ phase are data collected from the high-pressure optical cell, closed symbols in the gas (G) phase are calculated data; the half open symbols are experimental points of respectively the liquid and the gas phase measured in the high-pressure autoclave), $\circ 45^{\circ} \mathrm{C}$, data collected from Tan et al. (1991), Zhang et al. (2005), $\bullet 45^{\circ} \mathrm{C}$, this work (data in L were experimentally determined points, data in $\mathrm{G}$ were calculated), $\Delta 60^{\circ} \mathrm{C}$, data collected from Akgün et al. (2004), $\Delta 60^{\circ} \mathrm{C}$, this work (data in $L$ were experimentally determined, data in $G$ were calculated). Literature data are shown in terms of weight fractions, recalculated from the reported molar fractions. - Calculation with the Peng-Robinson equation of state; ….... 35 ${ }^{\circ} \mathrm{C}, \cdots 45{ }^{\circ} \mathrm{C},-60{ }^{\circ} \mathrm{C}, \mathrm{k}_{\mathrm{sty} / \mathrm{CO}_{2}}=0.046$ (Suppes and McHugh, 1989). The parameters $a(T), b$ and $\omega$ have been calculated from the critical properties of the components, see Appendix D.

The cloud-point measurements as well as the data from the high-pressure autoclave show good reproducibility, i. e. small experimental error (see Appendix C). Comparing cloud-points observed by Zhang et al. (2005) and the high-pressure autoclave equilibrium data $\left(35^{\circ} \mathrm{C}\right)$, a small deviation of only $0.51 \%$ exists. 
The experimentally determined values of the monomer concentration in the coexisting phases overlap the cloud-point data as well as the data of Zhang et al. (2005), demonstrating the reliability of the high-pressure autoclave.

Some discrepancies exist between data collected in the present work and the previously published data of Suppes and McHugh (1989), Tan et al. (1991) and Akgün et al. (2004). The authors mentioned reported P-x-y data at different temperatures, with $\mathrm{P}$ being the pressure in the syringe pump. So the pressure was not recorded inside the equilibrium cell and therefore the pressure decrease due to the decrease in the fugacity of the monomer and (sc) $\mathrm{CO}_{2}$ mixture on adding (sc) $\mathrm{CO}_{2}$ was not taken into account (see Chapter 2).

In the present work the experiments have been performed with a pressure indicator directly in contact with the binary mixture. 


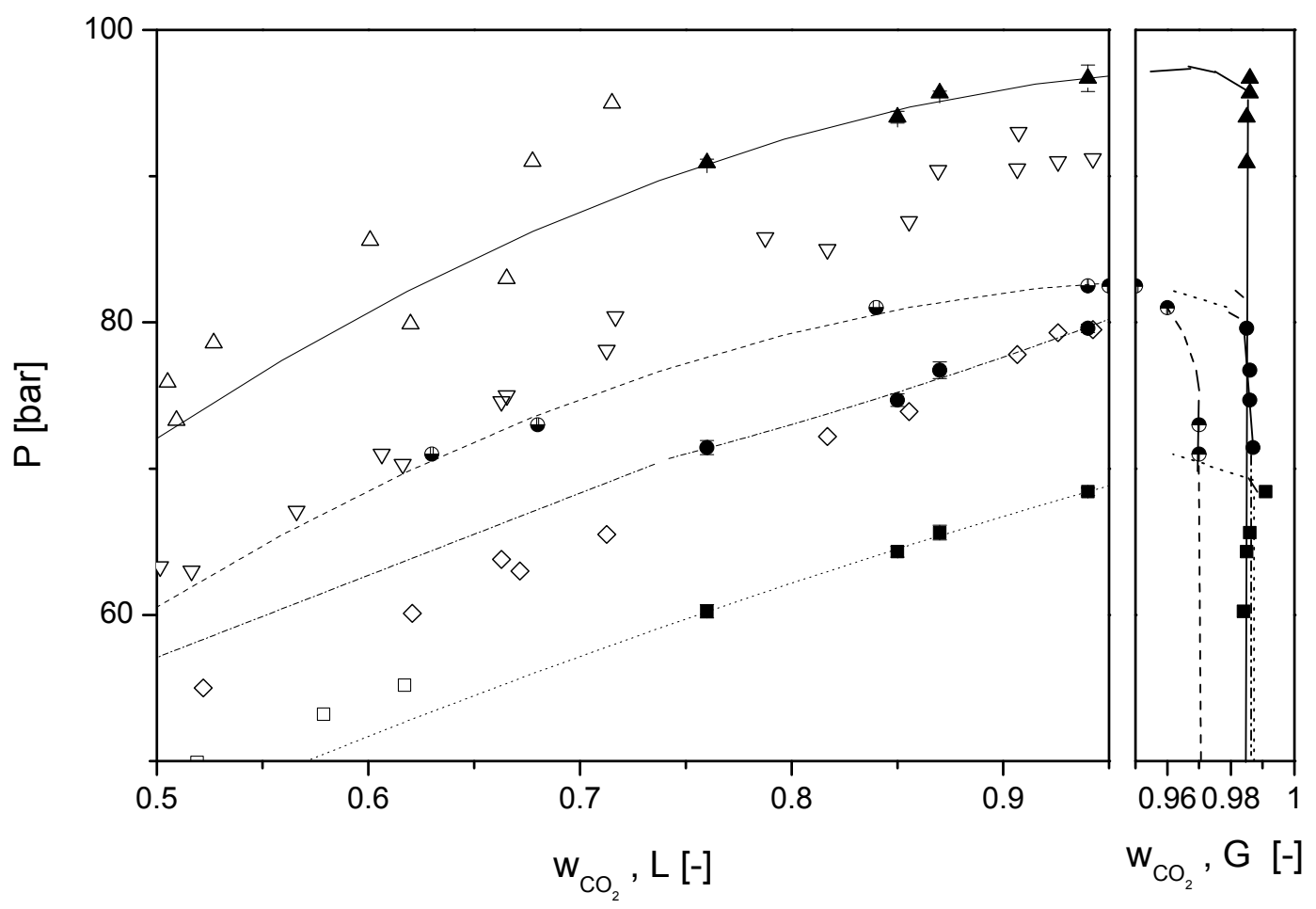

Figure 4 Cloud-point data of the MMA-CO $\mathrm{CO}_{2}$ binary system. $\square 35{ }^{\circ} \mathrm{C}$ Zwolak et al. (2005), 35 ${ }^{\circ} \mathrm{C}$ this work (data in $\mathrm{L}$ were experimentally determined points, data in $\mathrm{G}$ were calculated), $\diamond 40{ }^{\circ} \mathrm{C}$, data collected from Zwolak et al. (2005), da Silva et al. (2007), $\bullet$ this work $45{ }^{\circ} \mathrm{C}$ (solid symbols in the liquid $(\mathrm{L})$ phase represent data collected from the high-pressure optical cell, solid symbols in the gas $(G)$ phase were calculated; the half open symbols are experimental points, respectively of the liquid and gas phase measured in the high-pressure autoclave), $\nabla 50^{\circ} \mathrm{C}$, data collected from Zwolak et al. (2005), da Silva et al. (2007), Uzun et al. (2005), $\Delta 60{ }^{\circ} \mathrm{C}$, data collected from Zwolak et al. (2005), Uzun et al. (2005), $\Delta 60{ }^{\circ} \mathrm{C}$, this work (data in $L$ were experimentally determined points, data in $G$ were calculated). Literature data are shown in terms of weight fractions, recalculated from the reported molar fractions. - Calculations with the Peng-Robinson equation of state; $\cdots \cdots \cdots .35^{\circ} \mathrm{C}, \ldots . \ldots 5^{\circ} \mathrm{C},-60{ }^{\circ} \mathrm{C}$; $\mathrm{k}_{\mathrm{MMA} / \mathrm{CO}_{2}}=0.033$ (Zwolak et al., 2005). The parameters $\mathrm{a}(\mathrm{T}), \mathrm{b}$ and $\omega$ have been calculated from the critical properties of the components, see Appendix $D$.

To the best of the authors' knowledge no experimental vapor-liquid equilibria for the MMA(sc) $\mathrm{CO}_{2}$ system at $45{ }^{\circ} \mathrm{C}$ are reported in literature. Therefore, in Figure 4 , vapor-liquid data at 40 and $50{ }^{\circ} \mathrm{C}$ were included to check to what extent experimental data at $45^{\circ} \mathrm{C}$ determined in the present work agree with the trends reported by Zwolak et al. (2005), da Silva et al. (2007) and Uzun et al. (2005). 
The experimental error of the equilibrium data of the MMA-(sc) $\mathrm{CO}_{2}$ system reported in the present work is very small (see Appendix C), i. e. the experiments are very reproducible.

The results at 35 and $60{ }^{\circ} \mathrm{C}$ from the present work and from Zwolak et al. (2005) and da Silva et al. (2007) are comparable. The discrepancy with the data at $60^{\circ} \mathrm{C}$ from Uzun et al. (2005) is again probably due to the method of pressure indication. Uzun et al. (2005) measured the pressure outside the equilibrium cell, not taking into account the pressure decrease upon mixing MMA and $(\mathrm{sc}) \mathrm{CO}_{2}$, whereas in the present work the pressure is measured directly in the equilibrium cell. The $45{ }^{\circ} \mathrm{C}$ isotherm obtained from the cloud-point measurements matches the data of da Silva et al. (2007) and Zwolak et al. (2005) at $40{ }^{\circ} \mathrm{C}$, whereas the equilibrium data from the high-pressure autoclave are found between $40{ }^{\circ} \mathrm{C}$ and $50{ }^{\circ} \mathrm{C}$ for higher weight fractions; below a weight fraction of $\mathrm{CO}_{2}$ of 0.7 , the data fit more at the $50{ }^{\circ} \mathrm{C}$ isotherm. Although the cloud-point measurements at $45{ }^{\circ} \mathrm{C}$ show a small experimental error, the reason why the data show correspondence with the $40{ }^{\circ} \mathrm{C}$ data of Zwolak et al. (2005) and da Silva et al. (2007) is unknown. It is believed that the equilibrium data set measured with the high-pressure autoclave is accurate and reliable for the higher weight fractions of $\mathrm{CO}_{2}$, as the data are found right in between the $40{ }^{\circ} \mathrm{C}$ and $50{ }^{\circ} \mathrm{C}$ data from Zwolak et al. (2005) and da Silva et al. (2007). Following the trend of the curves of all data included in Figure 4, the experimental values of the pressure for $\mathrm{CO}_{2}$ weight fractions below 0.7 are somewhat too high.

All pressures obtained in the present work are well correlated by the Peng-Robinson equation of state (eos) using one adjustable parameter, the binary interaction parameter $\mathrm{k}_{\mathrm{ij}}$ (see Appendix D). The data collected by the other authors are also well described with the Peng-Robinson eos and the same value for $\mathrm{k}_{\mathrm{ij}}$ (for clarity the data calculations with the PengRobinson eos found in literature are not included in the respective graphs. The reader is referred to the articles of Zwolak et al. (2005) and Uzun et al. (2005)). This observation also holds for the data determined in the experimental set-up measuring the pressure outside the equilibrium cell. So the Peng-Robinson eos seems to correlate every data set very well, due to the simple mixing rules imported in the Peng-Robinson eos. All reported correlations, including the present work, use the symmetrical Van der Waals mixing rules (Poling, 2001). The interaction parameter $\left(a_{\text {mix }}\right)$ and the volume parameter $\left(b_{\text {mix }}\right)$, calculated from critical 
data, in the Van der Waals mixing rules have little sensitivity to small changes in pressure and weight fraction of the components.

For both the Sty-(sc) $\mathrm{CO}_{2}$ as well as the MMA-(sc) $\mathrm{CO}_{2}$ system it is observed that the monomer solubility in $\mathrm{CO}_{2}$ decreases with increasing temperature, i.e. at higher temperatures, a higher pressure is needed to obtain a homogeneous mixture, see Figure 5. The relation between solubility and pressure is expressed in Equation 1.

$\mathrm{y}_{\mathrm{m}} * \mathrm{P}_{\text {total }}=\gamma_{\mathrm{m}} * \mathrm{x}_{\mathrm{m}} * \mathrm{P}_{\mathrm{m}}^{\text {sat }}$

Figure $5 \mathrm{a}$ illustrates the solubility of Sty and $\mathrm{MMA}$ in $\mathrm{CO}_{2}$ at $35^{\circ} \mathrm{C}$, Figure $5 \mathrm{~b}$ at $60{ }^{\circ} \mathrm{C}$. Only the experimentally obtained data points are shown in the figures.
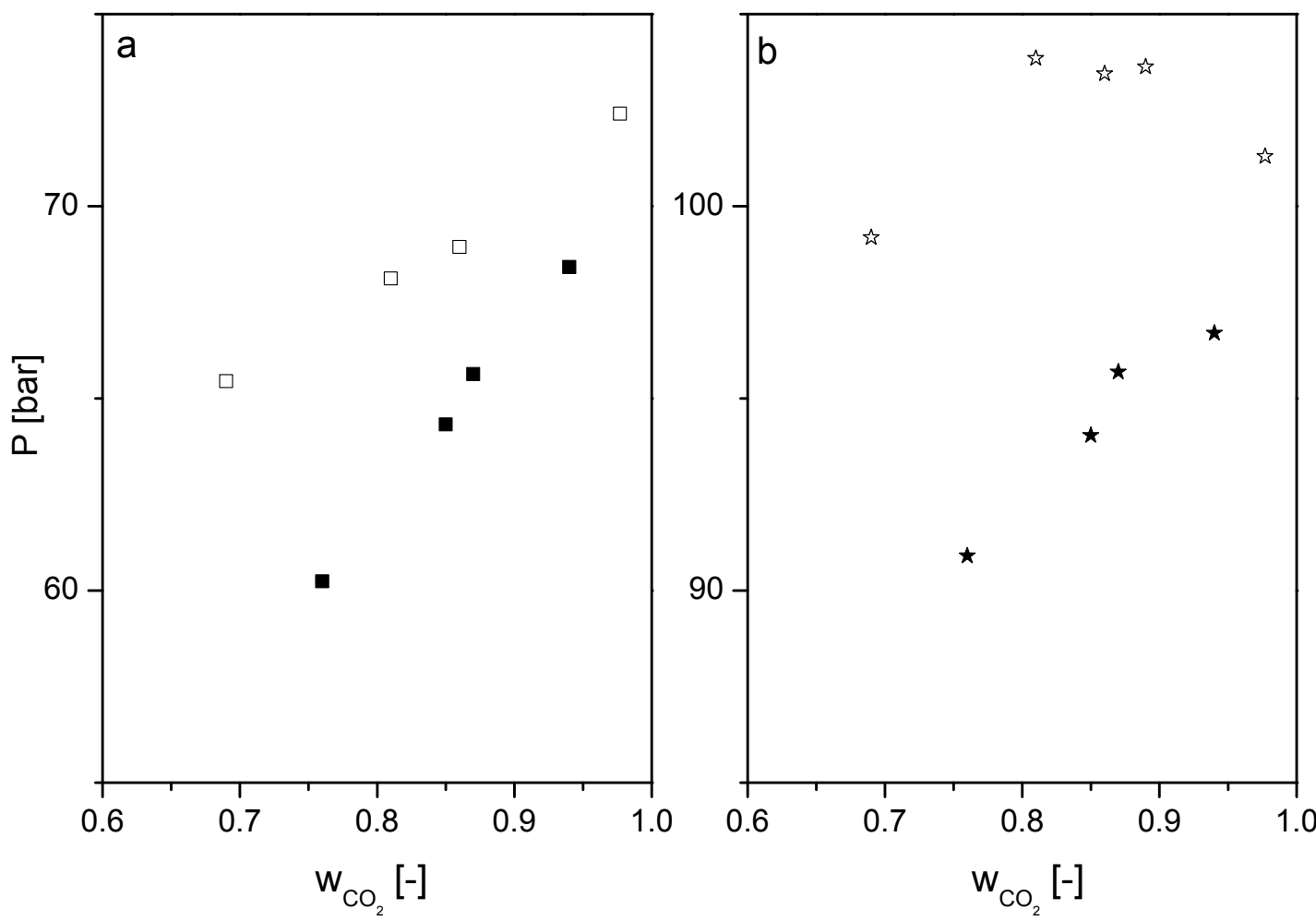

Figure 5 Phase separation pressure of Sty and MMA in (sc) $\mathrm{CO}_{2}$ at $35^{\circ} \mathrm{C}(\mathrm{a})$ and $60{ }^{\circ} \mathrm{C}(\mathrm{b})$. Open symbols represent Sty, solid symbols represent MMA. 
The results in Figure 5 demonstrate that Sty- $(\mathrm{sc}) \mathrm{CO}_{2}$ isotherms are shifted to higher pressures than MMA-(sc) $\mathrm{CO}_{2}$ isotherms. This behavior suggests that the molecular interactions between Sty and $(\mathrm{sc}) \mathrm{CO}_{2}$ are weaker than the $\mathrm{MMA}$ and $(\mathrm{sc}) \mathrm{CO}_{2}$ interactions, resulting in a lower solubility of Sty in (sc) $\mathrm{CO}_{2}$. Kazarian et al. (1996a) studied the specific interactions of $\mathrm{CO}_{2}$ with monomers to gain insight into interactions of $\mathrm{CO}_{2}$ with polymers. With Fourier transform infrared (FTIR) spectroscopy, Kazarian et al. (1996a) demonstrated that $\mathrm{CO}_{2}$ acts as a Lewis acid. An electron donor-acceptor complex between the carbonyl oxygen atom of MMA and the $\mathrm{CO}_{2}$ carbon atom is formed, increasing solubility. Styrene does not possess a carbonyl oxygen atom and therefore no strong Lewis acid-base interactions with $\mathrm{CO}_{2}$ exist. Other authors reported similar observations (Kazarian et al., 1996 b, Shieh and Liu, 2002).

The difference in solubility of Sty and MMA in $\mathrm{CO}_{2}$ is also explained by Equations 2 and 3 (DeVoe, 2001), see also Figure 6. Note that Equation 3 follows from Equation 2 using the Gibbs-Helmholtz relation with temperature independent heats of solution.

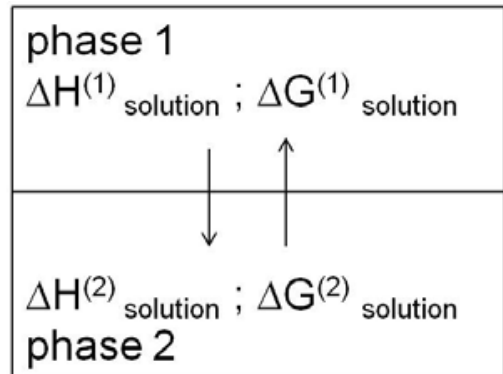

Figure 6 schematic representation of a monomer $/ \mathrm{CO}_{2}$ mixture.

The monomer distribution coefficient, i.e. the ratio of the monomer weight fraction in the vapor phase and the monomer weight fraction in the liquid phase, is expressed in terms of Gibbs free energies of solution, see Equation 2.

$$
\begin{aligned}
& \mathrm{K}_{\text {mon }}=\mathrm{e}^{\frac{-\Delta \Delta \mathrm{G}_{\text {solution }}}{\mathrm{R} * \mathrm{~T}}} \\
& \ln \frac{K_{\text {mon }}^{T_{2}}}{K_{\text {mon }}^{T_{1}}}=-\frac{\Delta \Delta H_{\text {solution }}}{R} *\left[\frac{1}{T_{2}}-\frac{1}{T_{1}}\right]
\end{aligned}
$$


The change in the heat of solution for a monomer solved in $\mathrm{CO}_{2}$ at constant pressure is calculated through the partition coefficient $\left(\mathrm{K}_{\mathrm{mon}}\right)$ of the monomer between the liquid and the vapor phase at a certain temperature. Figure 7 shows the relation between the partition coefficient and the temperature for both Sty- $\mathrm{CO}_{2}$ (solid symbols) and for $\mathrm{MMA}-\mathrm{CO}_{2}$ (open symbols) at 65.5 bar. The data points calculated from experimentally determined compositions have been collected in Appendix E.

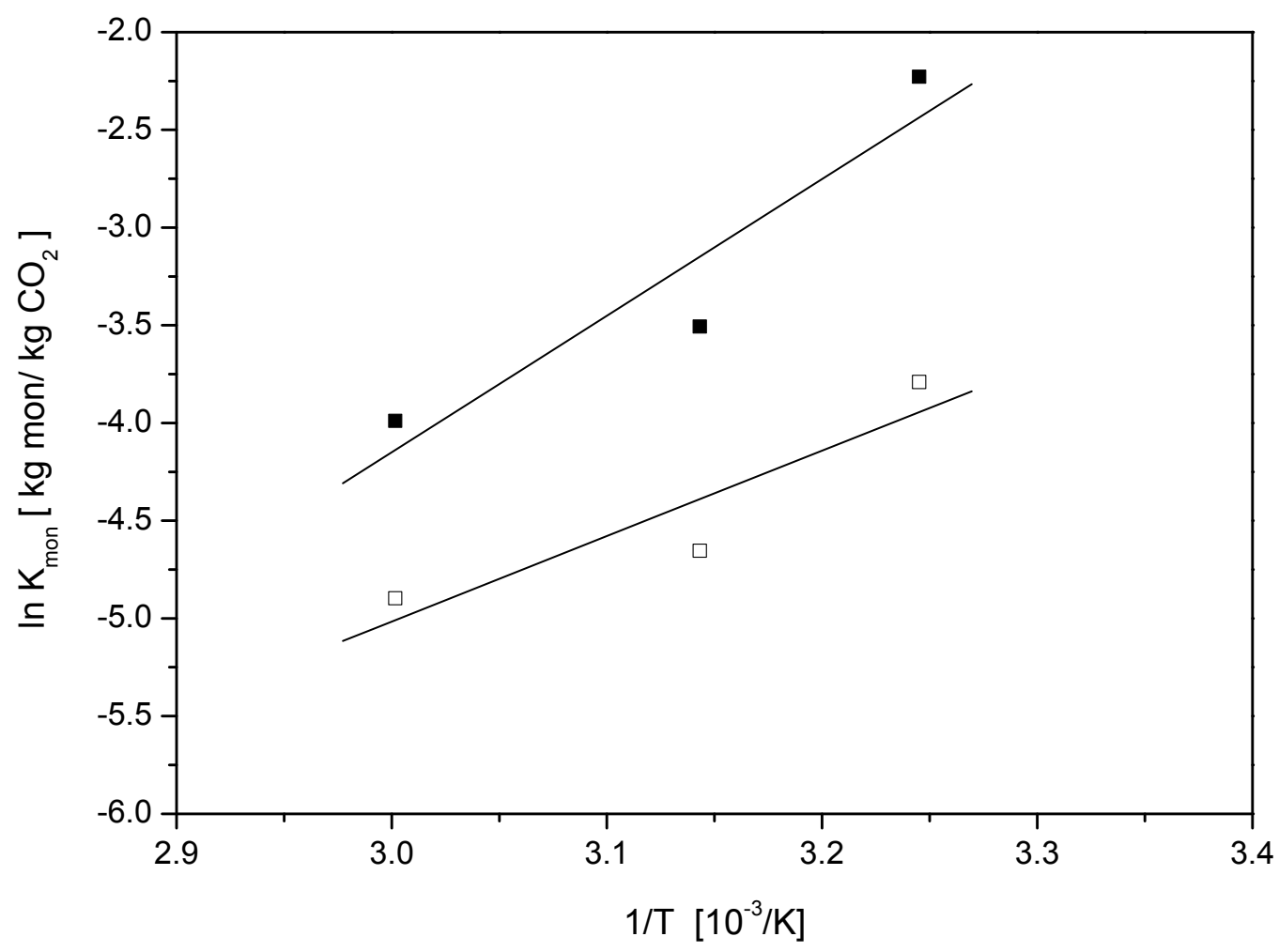

Figure 7 Partition coefficients for the distribution of monomer over the liquid phase and the vapor phase versus temperature at 65.5 bar. Open symbols represent Sty, solid symbols represent MMA. Data points are fitted to $\ln \mathrm{K}_{\mathrm{mon}}^{\mathrm{T}}=-\frac{\Delta \Delta \mathrm{H}_{\text {solution }}}{\mathrm{R}} *\left[\frac{1}{\mathrm{~T}}\right]+$ constant with $\mathrm{K}_{\mathrm{mon}}=\frac{\mathrm{w}_{\text {mon }}^{\text {vapor }}}{\mathrm{w}_{\text {mon }}^{\text {liquid }}}$.

The difference in heat of solution $\left(\Delta \Delta \mathrm{H}_{\text {solution }}=\Delta \mathrm{H}_{\text {solution }}\left(\mathrm{CO}_{2}\right)-\Delta \mathrm{H}_{\text {solution }}\left(\mathrm{CO}_{2}\right.\right.$ swollen polymer $\left.)\right)$ for Sty dissolved in $\mathrm{CO}_{2}$ is $\sim 38 \mathrm{~kJ} /$ mole, whereas for MMA this difference is $\sim-60 \mathrm{~kJ} / \mathrm{mole}$. 
Monomer partitioning over $\mathrm{CO}_{2}$ swollen polymer and $\mathrm{scCO}_{2}$

The monomer partitioning between $\mathrm{CO}_{2}$ swollen polymer and $(\mathrm{sc}) \mathrm{CO}_{2}$ has been determined at 100,140 and 180 bar at 35,45 and $60{ }^{\circ} \mathrm{C}$, by adding $10000 \mathrm{ppm}$ and $100 \mathrm{ppm}$ monomer. The amount of $10^{4} \mathrm{ppm}$ and $100 \mathrm{ppm}$ monomer to be added to the polymer/ $\mathrm{CO}_{2}$ mixture has been chosen to verify if the partition coefficient for distribution of monomer between $\mathrm{CO}_{2}$ swollen polymer and $(\mathrm{sc}) \mathrm{CO}_{2}$ remains constant at the same conditions of temperature and pressure even when the amount of monomer present decreases. 100 ppm has been chosen as the experimental lower limit as it becomes more difficult to add an accurate amount of monomer when the amount to add decreases. While analyzing the $\mathrm{CO}_{2}$ rich phase when only $100 \mathrm{ppm}$ of monomer was added to the system, the resulting concentration of monomer in $\mathrm{CO}_{2}$ was found to be much higher than $100 \mathrm{ppm}$. This result suggests that the received PS and PMMA polymer contain residual monomer. By means of several experiments and some iterations (see Appendix F) it was found that in the PS granules $(\sim 5 \mathrm{~mm})$ about 500 ppm styrene and in the smaller PS beads $(\sim 1 \mathrm{~mm})$ about $2600 \mathrm{ppm}$ styrene was left after polymerization; in the PMMA beads $(\sim 0.5 \mathrm{~mm})$ about $800 \mathrm{ppm}$ residual MMA was found.

Monomer partitioning between the polymer particles and $(\mathrm{sc}) \mathrm{CO}_{2}$ is expressed in the partition coefficient:

$\mathrm{K}_{\mathrm{m}}=\frac{\mathrm{C}_{\mathrm{m}}^{\mathrm{CO}_{2}}}{\mathrm{C}_{\mathrm{m}}^{\text {pol }}}\left[\frac{\mathrm{kg} \text { polymer }}{\mathrm{kg} \mathrm{CO} \mathrm{O}_{2}}\right]$

Figure 8a shows the results for the determination of the monomer partition coefficient for StyPS-(sc) $\mathrm{CO}_{2}$, Figure $8 \mathrm{~b}$ graphically represents the results for MMA-PMMA-(sc) $\mathrm{CO}_{2}$. The phase ratio is in the range 0.035 to $0.045 \mathrm{~g}$ polymer $/ \mathrm{g} \mathrm{CO}_{2}$. Both cases for the addition of approximately 10000 ppm and 100 ppm of monomer are included. 

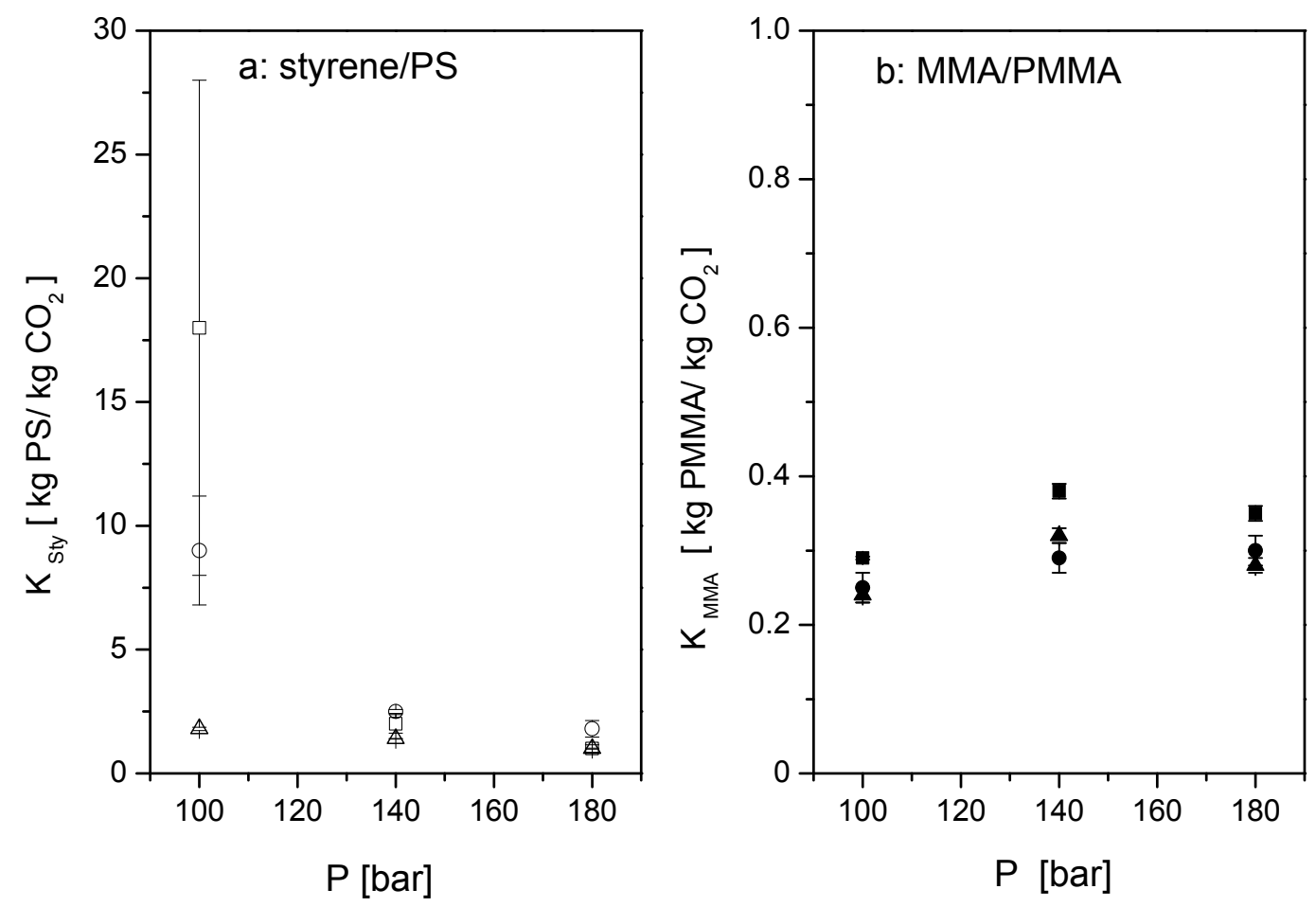

Figure 8 Partition coefficient for distribution of styrene between ( $\mathrm{sc}) \mathrm{CO}_{2}$ and PS (a, open symbols) and for distribution of MMA between (sc) $\mathrm{CO}_{2}$ and PMMA (b, solid symbols). 口, $35^{\circ} \mathrm{C}, \circ, \bullet 45^{\circ} \mathrm{C}, \Delta, \Delta 60^{\circ} \mathrm{C}$.

For 100 bar the partition coefficient of Sty at 35 and $45{ }^{\circ} \mathrm{C}$ shows an unexpected deviation (Appendix F). At higher pressures the partition coefficient has an approximately constant value of $2[\mathrm{~kg} \mathrm{PS} / \mathrm{kg} \mathrm{CO} 2$. The same results were obtained for a total of $10000 \mathrm{ppm}$ and for approximately $3000 \mathrm{ppm}$ (vide supra) styrene in the system. Also the particle diameter size did not influence the outcome. The partition coefficient of MMA between PMMA and (sc) $\mathrm{CO}_{2}$ is $\sim 0.3$ [kg PMMA/kg CO 2$]$ for every combination of pressure and temperature analyzed. The partition coefficients for 10000 ppm and approximately 1000 ppm (vide supra) MMA in the $\mathrm{PMMA} /(\mathrm{sc}) \mathrm{CO}_{2}$ mixture are equal.

Theoretical predictions of the partition coefficient with the Perturbed Chain - Statistical Association Fluid Theory (PC-SAFT) eos, see Chapter 2, and the work of Görnert and Sadowski (2007 and 2008) suggest that the partition coefficient depends on the (sc) $\mathrm{CO}_{2}$ 
density and on the solubility of the monomer in the $(\mathrm{sc}) \mathrm{CO}_{2}$ phase. The higher the density of the $(\mathrm{sc}) \mathrm{CO}_{2}$ phase, the higher the partition coefficient. The more soluble monomer (MMA) partitions more towards the (sc) $\mathrm{CO}_{2}$ than the less soluble monomer (Sty). The experimental values of the partition coefficient in the present work neither show a significant dependence on $(\mathrm{sc}) \mathrm{CO}_{2}$ density, nor show the expected influence of monomer affinity for $(\mathrm{sc}) \mathrm{CO}_{2}$, i.e. the partition coefficient of Sty between PS and $(\mathrm{sc}) \mathrm{CO}_{2}$ is found to be higher than the partition coefficient of MMA between PMMA and (sc) $\mathrm{CO}_{2}$.

The density profile of $\mathrm{CO}_{2}$, see Figure 9, demonstrates that at low pressures $\mathrm{CO}_{2}$ behaves more gas-like. The binary phase diagrams Sty- $\mathrm{CO}_{2}$ (Figure 3) and $\mathrm{MMA}-\mathrm{CO}_{2}$ (Figure 4) also show a large miscibility gap between monomer and $\mathrm{CO}_{2}$ in the lower pressure region, i.e. low solubility.

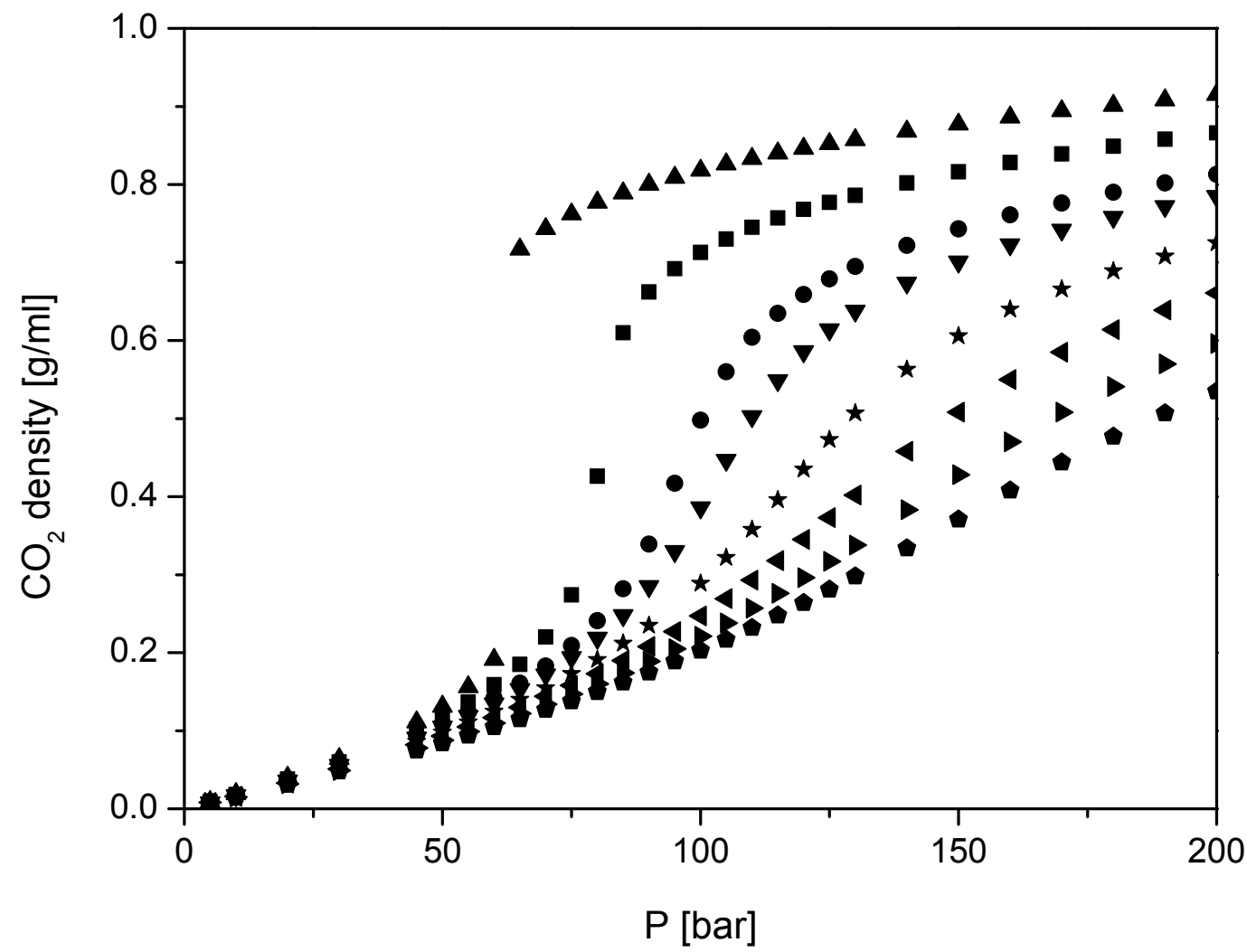

Figure $9 \mathrm{CO}_{2}$ density profile as a function of pressure for several temperatures. $\Delta 25{ }^{\circ} \mathrm{C}, \boldsymbol{\|} 35$ ${ }^{\circ} \mathrm{C}, \bullet 45{ }^{\circ} \mathrm{C}, \nabla 50{ }^{\circ} \mathrm{C}, \star 60{ }^{\circ} \mathrm{C}, 470{ }^{\circ} \mathrm{C}, \bullet 00^{\circ} \mathrm{C}, \bullet 90{ }^{\circ} \mathrm{C}$; data are calculated with the ModifiedWebb-Benedict-Ruben equation of state (Poling et al., 2001). 
At moderate pressures the $\mathrm{CO}_{2}$ density increases rapidly with increasing pressure, especially for temperatures lower than $60{ }^{\circ} \mathrm{C}$. At the same time the "solvency ability" of $\mathrm{CO}_{2}$ increases with increasing pressure. Hence, more monomer dissolves in the $\mathrm{CO}_{2}$ phase. At high pressures, $\mathrm{CO}_{2}$ becomes more liquid-like, making its density and solubility behavior less sensitive to pressure changes. Increasing temperature decreases the $\mathrm{CO}_{2}$ density and "solvency ability", i.e. less monomer uptake. On the other hand, higher temperatures improve the monomer volatility, increasing the driving force for monomer uptake by $\mathrm{CO}_{2}$. The experimental results demonstrate that the latter two effects rule each other out in the higher pressure region, keeping the partition coefficient approximately independent of pressure. Although Wu et al. (2002) found different values for the distribution coefficient of Sty between $\mathrm{PS}$ and $\mathrm{CO}_{2}$, these authors reported similar findings about the constancy of the value with increasing pressure and temperature.

A second issue is that both Görnert and Sadowski $(2007,2008)$ and Wu et al. (2002) perform their measurements with annealed polymers, i.e. the polymer product is heated above the glass transition temperature to remove so-called history effects. By heating the polymer above the $T_{g}$, build-in defects and specific characteristics introduced by the preparation method of the polymer disappear and a smooth polymer product is obtained. The databank used in the PC-SAFT modeling is also based on the characteristics of annealed polymers to calculate its parameters. Already in the seventies of the previous century, van de Ven (1975) emphasized the influence of history effects in analyzing polymer products, describing colloidal interactions. Huvard et al. (1980) reported about the influence of annealing poly acrylonitrile (PAN) on $\mathrm{CO}_{2}$ sorption. Huvard et al. (1980) observed that the sorption capacity of glassy PAN microspheres decreased by $\sim 30 \%$ after annealing the microspheres in comparison to the "as made" microspheres. The author refers to Koros et al. (1978) and to Chan et al. (1978) who observed similar effects in $\mathrm{CO}_{2}$ sorption in poly(ethylene terephtalate) and in polycarbonate, respectively. In the present work the polymers are used as received from industry, without annealing the product.

A third aspect concerns a possible explanation why the experimentally determined partition coefficient for Sty is higher than that for MMA, while the theory predicted it the other way around. Polymers can form physical or entangled networks including ion bridging from one 
chain to another and hydrophobic and hydrophilic bonding (Goodwin and Hughes, 2008). Entanglements in amorphous polymers refer to the degree of topological constraint on the relative chain motion. An amorphous polymer, both in the glassy and rubbery state can often be idealized as a network of entangled strands linked at entanglement points. The entanglement network is characterized by, for example, the density of the entanglement points (Teerenstra et al., 2003). Teerenstra et al. (2003) pointed out that not only the chain flexibility is important for the entanglement density, but also the chain diameter plays a significant role. These authors observed that a larger chain diameter decreases the entanglement density. The phenyl side groups of PS are larger than the alkyl groups of PMMA. Bucknall (2001) found that the degree of ductility of a polymeric material also depends on the entanglement density, both decreasing from polycarbonate to polyvinylchloride to PMMA to PS. For PS 1.35 bonds per $\mathrm{nm}^{3}$ are counted, for PMMA 1.50 bonds per $\mathrm{nm}^{3}$. Meijer et al. (2000) also reported an increase of the entanglement density from PS to PMMA. The findings of the authors mentioned are applicable to polymer films, polymer melts and diluted polymer samples. High-pressure $\mathrm{CO}_{2}$ acts as a plasticizing agent, swelling the polymer, thereby decreasing the volume fraction of the polymer. The glass transition temperature of the polymer also decreases changing the polymer from the glassy to the rubbery state. The plasticization, characterized by increased segmental motion, chain mobility and inter-chain distance, is largely determined by polymer-solvent interactions and solvent size (Kazarian, 2000). As mentioned earlier, PMMA and (sc) $\mathrm{CO}_{2}$ form an electron donor-acceptor complex (Kazarian et al., 1996a) which results in an additional network link decreasing the distance between entanglements, i.e. increasing the entanglement density (Goodwin and Hughes, 2008, Brown, 2001). Therefore it is believed that it is easier to extract Sty from PS than MMA from PMMA due to the higher entanglement density of PMMA.

The same partitioning experiments as presented in Figure 8 have been performed with polymer beads equilibrated with water. The polymer beads were completely immersed in demineralized water for several days. Before the experiment started, the water attached to the surface of the polymer particles was removed. The results for monomer partitioning between polymer equilibrated with water and $(\mathrm{sc}) \mathrm{CO}_{2}$ and those between dry polymer and (sc) $\mathrm{CO}_{2}$ are not significantly different. There exists no influence of traces of water in the polymer phase on the monomer partitioning between $\mathrm{CO}_{2}$-swollen polymer and $\mathrm{scCO}_{2}$. 


\section{Concluding remarks}

A high-pressure optical cell and a high-pressure autoclave have been used to determine the binary phase behavior for Sty- $\mathrm{CO}_{2}$ and for $\mathrm{MMA}-\mathrm{CO}_{2}$. The optical cell as well as the highpressure autoclave are found to provide accurate results. In the high-pressure autoclave the monomer partition coefficients for distribution of monomer between $\mathrm{CO}_{2}$-swollen polymer particles and $(\mathrm{sc}) \mathrm{CO}_{2}$ have been experimentally determined at various pressures between 100 and 180 bar at various temperatures between 35 and $60{ }^{\circ} \mathrm{C}$. The experimental results demonstrate the partition coefficient is approximately independent of pressure and temperature. For Sty-PS-(sc) $\mathrm{CO}_{2}$ a partition coefficient of 2 [kg PS/kg (sc) $\left.\mathrm{CO}_{2}\right]$ is found for the different combinations of pressure and temperature, for MMA-PMMA-(sc) $\mathrm{CO}_{2}$ a value of $0.3\left[\mathrm{~kg} \mathrm{PMMA} / \mathrm{kg}(\mathrm{sc}) \mathrm{CO}_{2}\right]$ is observed. 


\section{References}

M. Akgün, D. Emel, N. Baran, N. A. Akgün, S. Deniz, S. Dinçer, "Styrene-carbon dioxide phase equilibria at high pressures", J. Supercritical Fluids, 2004, 31, 27-32

H. R. Brown, "Relation between the width of an interface between two polymers and its toughness", Macromol., 2001, 34, 11, 3720-3724

C. B. Bucknall, "Blends containing core-shell impact modifiers Part 1: Structure and tensile deformation mechanisms", Pure Appl. Chem., 2001, 73, 6, 897-912

A. H. Chan, D.R. Paul, "Effect of sub $-\mathrm{T}_{\mathrm{g}}$ annealing on $\mathrm{CO}_{2}$ sorption in polycarbonate", $A C S$ Preprints, 1978, 39, 230

H. DeVoe, "Thermodynamics and Chemistry", 2001, Prentice Hall, New York

J. W. Goodwin, R. W. Hughes, "Rheology for chemists: An introduction", $2^{\text {nd }}$ new ed., 2008, Royal Society of Chemistry, Cambridge

M. Görnert, G. Sadowski, "Phase-equilibrium measurements of the polystyrene/styrene/carbon dioxide ternary system at elevated pressures using ATR-FTIR spectroscopy", Macromol. Symp., 2007, 259, 236-242

M. Görnert, G. Sadowski, "Phase-equilibrium measurement and modeling of the PMMA/MMA/carbon dioxide ternary system", J. Supercritical Fluids, 2008, 46, 218-225

G. S. Huvard, V. T. Stannett, W. J. Koros, H. P. Hopfenberg, "The pressure dependence of $\mathrm{CO}_{2}$ sorption and permeation in poly(acrylonitrile)", J. of Membrane Sci., 1980, 6, 185-201

S. G. Kazarian, C. A. Eckert, J. C. Meredith, K. P. Johnston, J. M. Seminario, "Quantitative equilibrium constants between $\mathrm{CO}_{2}$ and Lewis bases from FTIR spectroscopy", J. Phys. Chem., 1996 (a) , 100, 10837-10848

S. G. Kazarian, M. F. Vincent, F. V. Bright, C. L. Liotta, C. A. Eckert, "Specific intermolecular interaction of carbon dioxide with polymers”, J. Am. Chem. Soc., 1996 (b), 118, 1729-1736

S. G. Kazarian, "Review: Polymer processing with supercritical fluids", Polym. Sci., Ser. C, 2000, 42, 78-101

W. J. Koros, D. R. Paul, " $\mathrm{CO}_{2}$ sorption in poly(ethylene terephthalate) above and below the glass transition temperature", J. Polym. Sci., Polym. Phys. Ed., 1978, 16, 1947

K.-M. Krüger, G. Sadowski, "Fickian and non-fickian sorption kinetics of toluene in glassy polystyrene", Macromol., 2005, 38, 8408-8417

M. Lora, M. A. McHugh, "Phase behavior and modeling of the poly(methyl methacrylate)$\mathrm{CO}_{2}$-methyl methacrylate system", Fluid Phase Eq., 1999, 157, 285-297

H. E. H. Meijer, L. E. Govaert, R. J. M. Smit, "A multi-level finite element method for modeling rubber-toughened amorphous polymers" in R. A. Pearson, H. -J. Sue, A. F. Yee (Eds.) "Toughening of plastics: advances in modeling and experiments", 2000, American Chemical Society, Washington D. C.

B. E. Poling, J. M. Prausnitz, J. P. O'Connell, "The properties of gases and liquids", $5^{\text {th }}$ ed., 2001, The McGraw-Hill Companies, Inc., USA 
M. S. da Silva, M. Temtem, S. Henriques, T. Casimiro, A. Aguiar-Rocardo, "Phase behavior studies of 2-hydroxylethyl methacrylate and methyl methacrylate in high-pressure carbon dioxide", J. Chem. Eng. Dat., 2007, 52, 5, 1970-1974

Y.-T. Shieh, K.-H. Liu, "Solubility of $\mathrm{CO}_{2}$ in glassy PMMA and PS over a wide pressure range: the effect of the carbonyl groups", J. Polym. Res., 2002, 9, 107-113

G. J. Suppes, M. McHugh, "Phase behavior of the carbon dioxide-styrene system", J. Chem. Eng. Dat., 1989, 34, 310-312

C.-S. Tan, S.- J. Yarn, J.- H. Hsu, "Vapour-liquid equilibria for the systems carbon dioxideethylbenzene and carbon dioxide-styrene", J. Chem. Eng. Dat., 1991, 36, 23-25

M. N. Teernestra, P. A. M. Steeman, W. Iwnes, A. Vandervelden, D. R. Suwier, B. Van Mele, C. E. Koning, "On the entanglement density of differently $\mathrm{N}$-substituted styrene-maleimide copolymers", e-Polym., 2003, 045, 1-12

N. I. Uzun, M. Akgün, N. Baran, S. Deniz, S. Dinçer, "Methyl methacrylate plus carbon dioxide phase equilbria at high pressures", J. Chem. Eng. Dat., 2005, 50, 4, 1144-1147

T. G. M. van de Ven, PhD thesis, 1975, McGill University, Montreal, Canada

J. Wu, Q. Pan, G. L. Rempel, "High pressure phase equilibria for a styrene/ $\mathrm{CO}_{2} /$ polystyrene ternary system", J. Appl. Polym. Sci., 2002, 85, 1938-1944

J. Zhang, L. Gao, X. Zhang, B. Zong, T. Jiang, B. Han, "Phase behaviors, density, and isothermal compressibility of styrene $+\mathrm{CO}_{2}$, ethylbenzene $+\mathrm{CO}_{2}$, and ethylbenzene + styrene+ $\mathrm{CO}_{2}$ systems", J. Chem. Eng. Data, 2005, 50, 1818-1822

G. Zwolak, L Lioe, F. P. Lucien, "Vapor-liquid equilibria of carbon dioxide plus methyl methacrylate at 308, 313, 323 and 333 K", Ind. Eng. Chem. Res., 2005, 44, 1021-1026 


\section{Appendix A}

Concentration time history of monomer in $\mathrm{CO}_{2}$, Figure A.1.a shows the profile for Sty in $\mathrm{CO}_{2}$ at $35{ }^{\circ} \mathrm{C}$ and 100 bar, Figure A.1.b for $\mathrm{MMA}$ in $\mathrm{CO}_{2}$. After about 2 hours the equilibrium concentration is set.
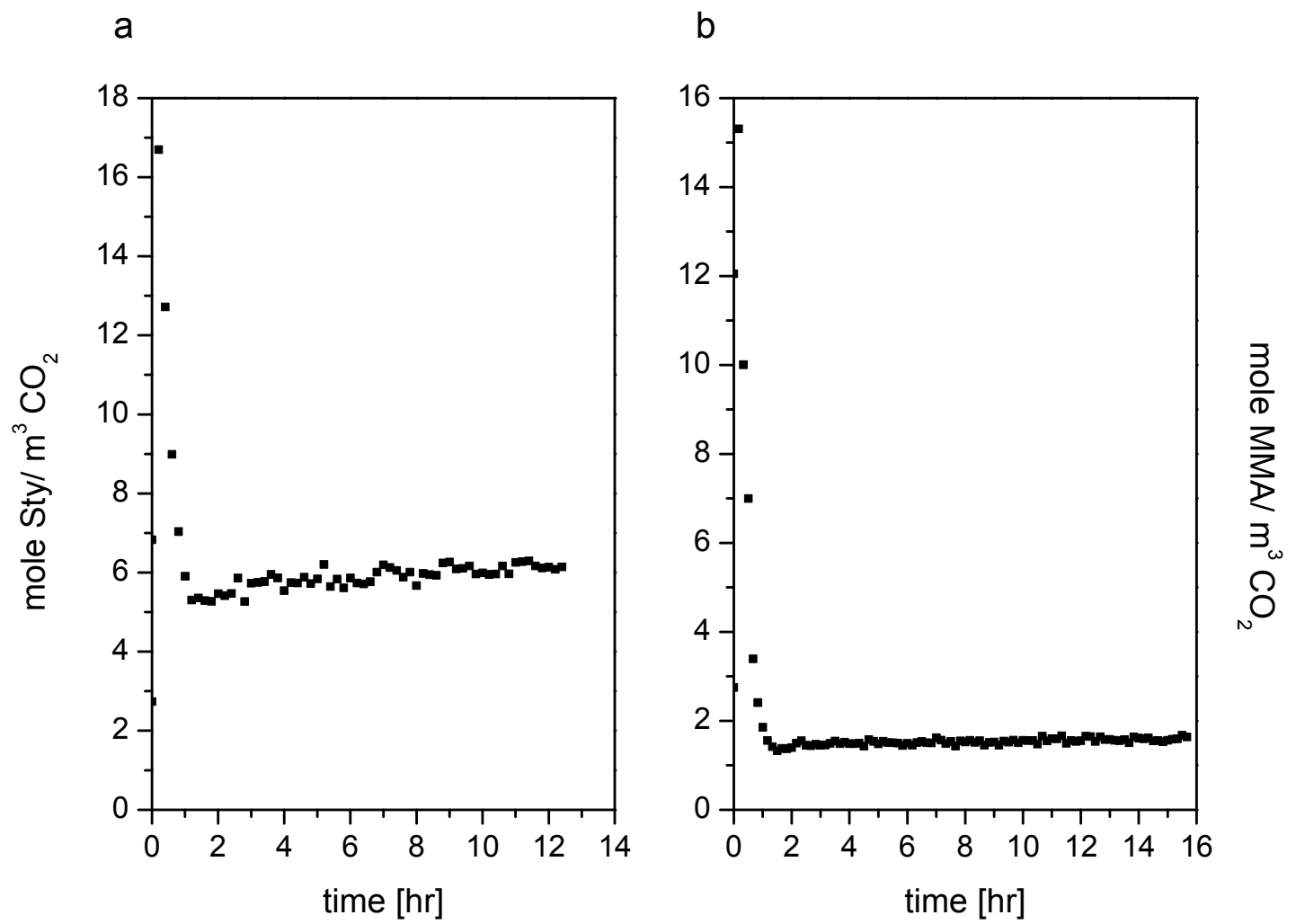

Figure A. 1 Concentration profile of a) Sty in $\mathrm{CO}_{2}$ and b) $\mathrm{MMA}$ in $\mathrm{CO}_{2}$.

Krüger and Sadowski (2005) studied the sorption kinetics of toluene in glassy polystyrene. Krüger reported the toluene mass uptake in polystyrene films of thicknesses between 20 and $100 \mu \mathrm{m}$ at $100{ }^{\circ} \mathrm{C}$ while increasing the pressure from $0-400$ mbar. The resulting curves show that sorption of toluene in polystyrene is very slow and can take several days or weeks before equilibrium is reached.

The reason equilibrium in this work is reached rather fast, only 2 hours, is ascribed to the preparation of the polymer samples. Krüger and Sadowski (2005) made the polymer films by increasing the polymer temperature above its glass transition temperature, thereby removing all influences of the polymerization process. In the present work the polymer particles are 
used as received as it is this kind of polymer that in general is the reactor product applied in industry. 


\section{Appendix B}

Figure B.1 and B.2 show the calibration plots of the peak area in the chromatogram as a function of the amount of moles $\mathrm{CO}_{2}$ injected. The calibration has been described with two separate equations due to the behavior of $\mathrm{CO}_{2}$. Up till an amount of $1.3 * 10^{-5}$ moles $\mathrm{CO}_{2}$ injected, the resulting plot can be described with an exponential function, see Equation B.1.

$y=p(1) * e^{(x * p(2))^{-1}}$

where $p(1)$ and $p(2)$ stand for the coefficients fitted to the plot $\left(p(1)=6.17 * 10^{-6}\right.$ and $p(2)=$ $0.24 * 10^{-6}$ respectively).

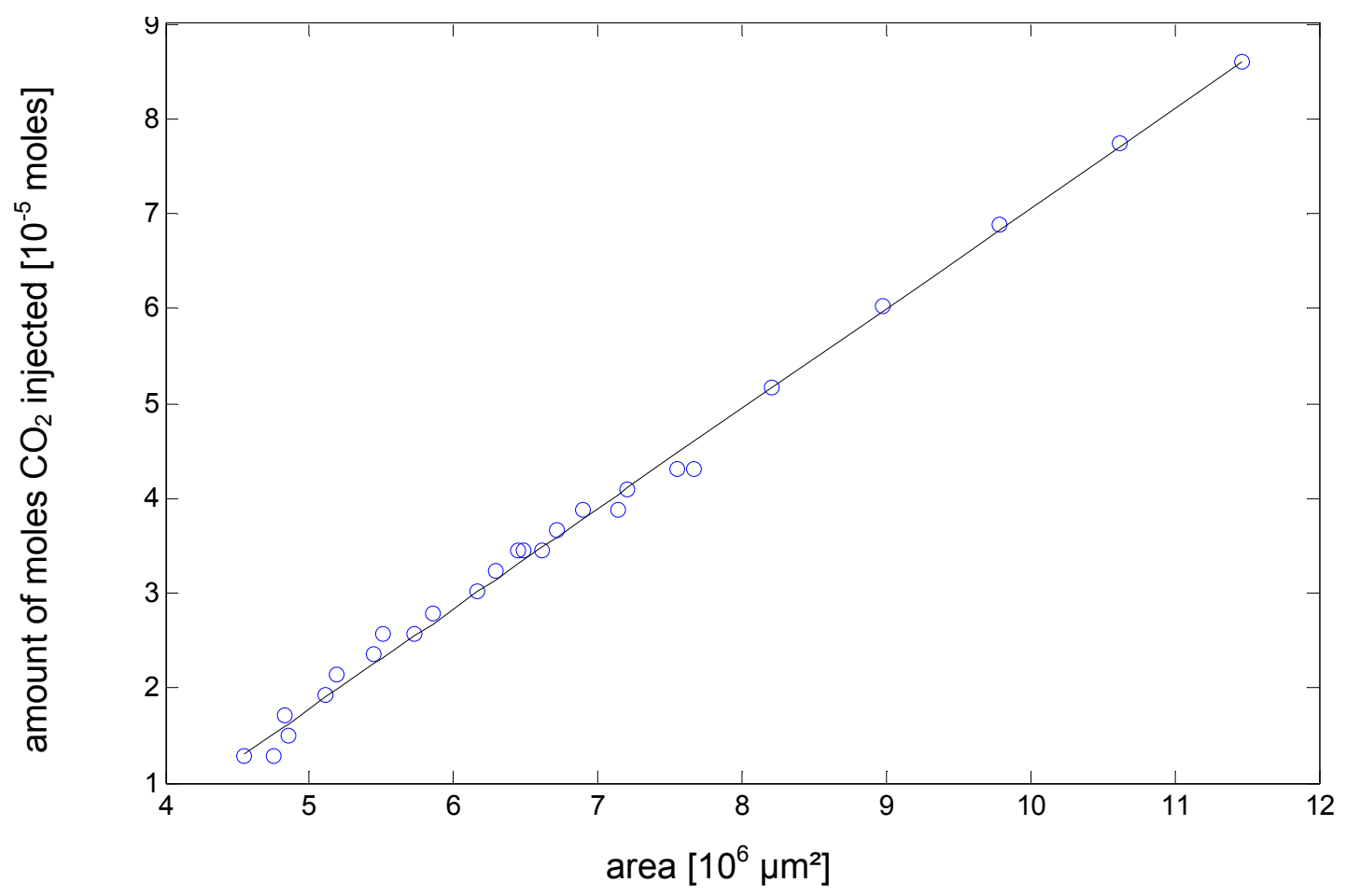

Figure B.1 Peak area as a function of the amount of moles $\mathrm{CO}_{2}$ injected $\left(<1.3 * 10^{-5}\right.$ moles $\mathrm{CO}_{2}$ ) into the gas chromatograph. The open symbols represent the measured peak areas of an accurately known amount of moles $\mathrm{CO}_{2}$ injected. The solid line represents the calibration line fitted to the data, $\mathrm{y}=\mathrm{p}(1) * \mathrm{e}^{(\mathrm{x} * \mathrm{p}(2))^{-1}}$

Once the amount of moles $\mathrm{CO}_{2}$ injected surmounts $1.3 * 10^{-5}$ moles $\mathrm{CO}_{2}$, the measured data points have been found to show a linear relation between the peak area and the amount of moles $\mathrm{CO}_{2}$ injected, see Equation B.2 and Figure B.2. 
$y=p(1)+p(2) * x$

where $p(1)$ and $p(2)$ stand for the coefficients fitted to the plot $\left(p(1)=-0.35 * 10^{-4}\right.$ and $p(2)=$ $1.1 * 10^{-11}$ respectively).

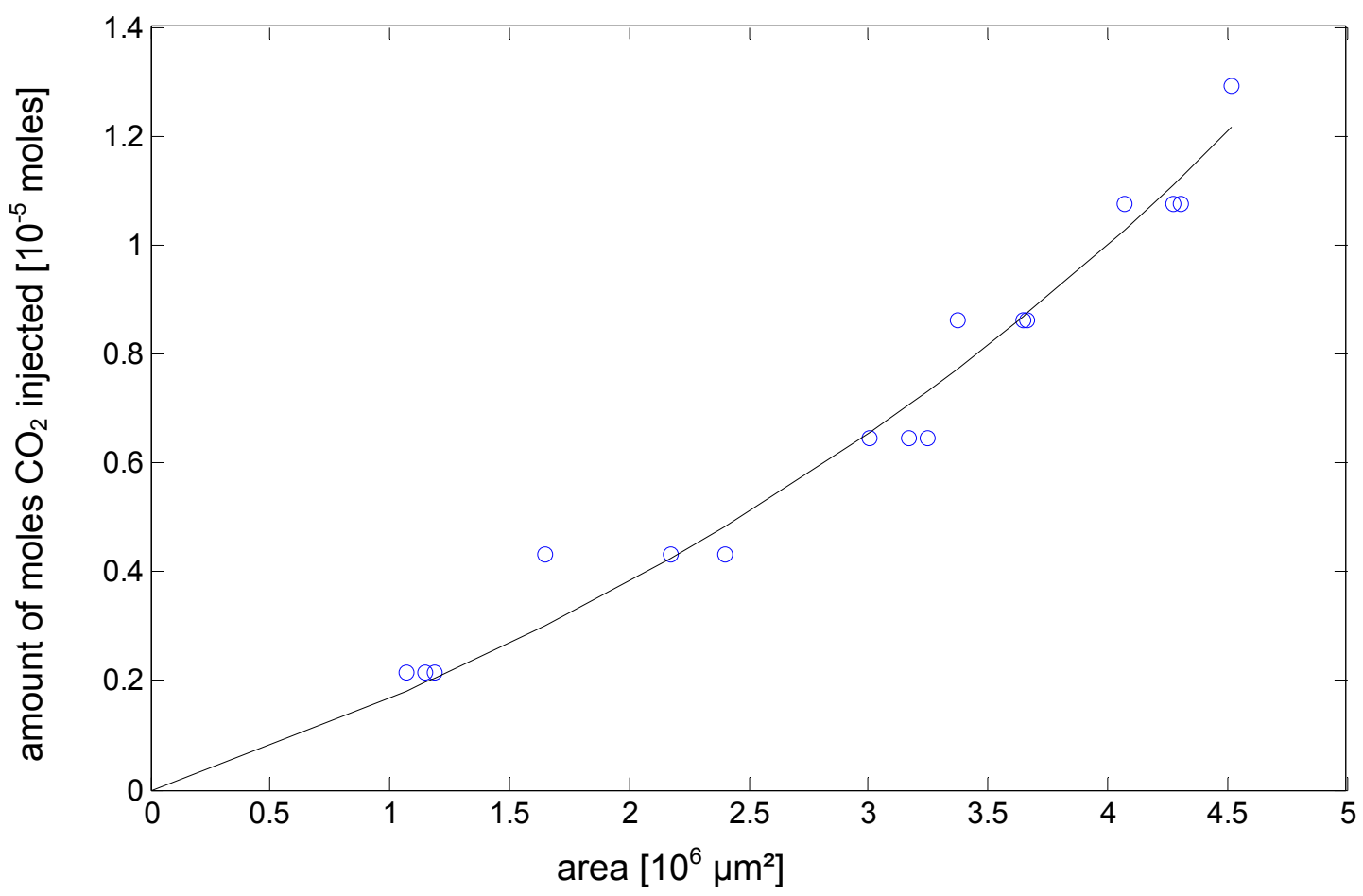

Figure B.2 Peak area in function of the amount of moles $\mathrm{CO}_{2}$ injected $\left(>1.3 * 10^{-5}\right.$ moles $\mathrm{CO}_{2}$ ) into the gas chromatograph. The open symbols represent the measured peak areas of an accurately known amount of moles $\mathrm{CO}_{2}$ injected. The solid line represents the calibration line fitted to the data, $y=p(1)+p(2) * x$ 


\section{Appendix C}

Experimentally determined cloud-points of Sty-(sc) $\mathrm{CO}_{2}$ and MMA-(sc) $\mathrm{CO}_{2}$ at 35,45 and 60 ${ }^{\circ} \mathrm{C}$ are presented in Table C.1.a and C.2.a respectively. The pressure is the calculated mean of all the experiments at one condition \pm the standard deviation. Liquid and gas phase compositions of Sty-(sc) $\mathrm{CO}_{2}$ at $35{ }^{\circ} \mathrm{C}$ and of MMA-(sc) $\mathrm{CO}_{2}$ at $45{ }^{\circ} \mathrm{C}$ are collected in Table C.1.b and C.2.b. The weight fraction of $(\mathrm{sc}) \mathrm{CO}_{2}$ is the calculated mean of all the experiments at one condition \pm the standard deviation.

Table C.1.a Cloud-point data of Sty-(sc) $\mathrm{CO}_{2}$

\begin{tabular}{c|c|c|c}
\hline$w_{\mathrm{CO}_{2}}$ & $\mathrm{P}$ [bar] at $35^{\circ} \mathrm{C}$ & $\mathrm{P}$ [bar] at $45^{\circ} \mathrm{C}$ & $\mathrm{P}$ [bar] at $60{ }^{\circ} \mathrm{C}$ \\
\hline \hline 0.98 & $72.4 \pm 0.8$ & $87 \pm 4$ & $101 \pm 1$ \\
\hline 0.89 & & $827 \pm 1$ & $104 \pm 1$ \\
\hline 0.86 & $69 \pm 2$ & $80 \pm 2$ & $104 \pm 2$ \\
\hline 0.81 & $68 \pm 2$ & $81 \pm 3$ & $104 \pm 1$ \\
\hline 0.69 & $66 \pm 2$ & $78 \pm 1$ & $99 \pm 2$ \\
\hline
\end{tabular}

Table C.1.b Liquid and gas phase compositions of Sty-(sc) $\mathrm{CO}_{2}$ at $35^{\circ} \mathrm{C}$

\begin{tabular}{c|c|c}
\hline $\mathrm{P}$ [bar] at $35^{\circ} \mathrm{C}$ & $w_{\mathrm{CO}_{2}}$ in the liquid phase & $w_{\mathrm{CO}_{2}}$ in the gas phase \\
\hline \hline 72 & $0.934 \pm 0.008$ & $0.995 \pm 0.0017$ \\
\hline 70 & $0.829 \pm 0.034$ & $0.994 \pm 0.0004$ \\
\hline
\end{tabular}


Table C.2.a Cloud-point data of MMA-(sc) $\mathrm{CO}_{2}$

\begin{tabular}{c|c|c|c}
\hline$w_{\mathrm{CO}_{2}}$ & $\mathrm{P}\left[\right.$ bar] at $35^{\circ} \mathrm{C}$ & $\mathrm{P}$ [bar] at $45^{\circ} \mathrm{C}$ & $\mathrm{P}$ [bar] at $60{ }^{\circ} \mathrm{C}$ \\
\hline \hline 0.94 & $68 \pm 0.3$ & $80 \pm 0.3$ & $97 \pm 0.9$ \\
\hline 0.87 & $6 \pm 0.5$ & $77 \pm 0.6$ & $96 \pm 0.1$ \\
\hline 0.85 & $64 \pm 0.4$ & $74 \pm 0.4$ & $94 \pm 0.4$ \\
\hline 0.76 & $60 \pm 0.5$ & $71 \pm 0.5$ & $91 \pm 0.3$ \\
\hline
\end{tabular}

Table C.2.b Liquid and gas phase compositions of MMA-(sc) $\mathrm{CO}_{2}$

\begin{tabular}{c|c|c}
\hline $\mathrm{P}$ [bar] at $45^{\circ} \mathrm{C}$ & $w_{\mathrm{CO}_{2}}$ in the liquid phase & $w_{\mathrm{CO}_{2}}$ in the gas phase \\
\hline \hline 82.5 & $0.94 \pm 0.0002$ & $0.95 \pm 0.0007$ \\
\hline 81 & $0.84 \pm 0.0014$ & $0.96 \pm 0.0002$ \\
\hline 73 & $0.68 \pm 0.0005$ & $0.97 \pm 0.0001$ \\
\hline 71 & $0.63 \pm 0.0007$ & $0.97 \pm 0.00004$ \\
\hline
\end{tabular}




\section{Appendix D}

Tables D.1 and D.2 show the vapor-liquid equilibria of Sty- $\mathrm{CO}_{2}$ and of $\mathrm{MMA}-\mathrm{CO}_{2}$ at $35^{\circ} \mathrm{C}, 45$ ${ }^{\circ} \mathrm{C}$ and $60{ }^{\circ} \mathrm{C}$ respectively. The composition of the liquid phase $[\mathrm{L}]$ is weighed into the equilibrium cell. The vapor phase [V] composition is calculated with the Peng-Robinson Equation of State, with a binary interaction parameter of 0.046 for Sty- $\mathrm{CO}_{2}$ (Suppes and McHugh, 1989) and 0.033 for $M M A-\mathrm{CO}_{2}$ (Zwolak et al., 2005). Table D.3 gives the pure component parameters used in the Peng-Robinson eos.

Table D.1.a Vapor-liquid equilibria of Sty- $\mathrm{CO}_{2}$ at $35^{\circ} \mathrm{C}$.

\begin{tabular}{c|c|c|c|c|c}
\hline $\mathrm{P}[\mathrm{bar}]$ & $\mathrm{w}_{\text {Sty }}[\mathrm{L}]$ & $\mathrm{w}_{\text {Sty }}[\mathrm{V}]$ calc & $\mathrm{w}_{\mathrm{CO}_{2}}[\mathrm{~V}]$ calc & $\mathrm{K}_{\text {Sty }}$ & $\mathrm{K}_{\mathrm{CO}_{2}}$ \\
\hline \hline 72.4 & 0.02 & 0.003 & 0.997 & 0.12 & 1.03 \\
\hline 68.9 & 0.14 & 0.008 & 0.992 & 0.06 & 1.16 \\
\hline 68.1 & 0.19 & 0.007 & 0.993 & 0.04 & 1.23 \\
\hline 65.5 & 0.31 & 0.007 & 0.993 & 0.22 & 1.43 \\
\hline
\end{tabular}

Table D.1.b Vapor-liquid equilibria of Sty- $\mathrm{CO}_{2}$ at $45^{\circ} \mathrm{C}$

\begin{tabular}{c|c|c|c|c|c}
\hline $\mathrm{P}[$ bar] & $\mathrm{w}_{\text {Sty }}[\mathrm{L}]$ & $\mathrm{w}_{\text {Sty }}[\mathrm{V}]$ calc & $\mathrm{w}_{\mathrm{CO}_{2}}[\mathrm{~V}]$ calc & $\mathrm{K}_{\text {Sty }}$ & $\mathrm{K}_{\mathrm{CO}_{2}}$ \\
\hline \hline 86.9 & 0.02 & 0.003 & 0.997 & 0.13 & 1.02 \\
\hline 81.7 & 0.11 & 0.003 & 0.997 & 0.03 & 1.12 \\
\hline 80.4 & 0.14 & 0.003 & 0.997 & 0.02 & 1.16 \\
\hline 80.9 & 0.19 & 0.003 & 0.997 & 0.015 & 1.23 \\
\hline 77.5 & 0.31 & 0.004 & 0.996 & 0.013 & 1.44 \\
\hline
\end{tabular}

Table D.1.c Vapor-liquid equilibria of Sty- $\mathrm{CO}_{2}$ at $60{ }^{\circ} \mathrm{C}$

\begin{tabular}{c|c|c|c|c|c}
\hline $\mathrm{P}[\mathrm{bar}]$ & $\mathrm{w}_{\text {Sty }}[\mathrm{L}]$ & $\mathrm{w}_{\text {Sty }}[\mathrm{V}]$ calc & $\mathrm{w}_{\mathrm{CO}_{2}}[\mathrm{~V}]$ calc & $\mathrm{K}_{\text {Sty }}$ & $\mathrm{K}_{\mathrm{CO}_{2}}$ \\
\hline \hline 101.3 & 0.02 & 0.01 & 0.989 & 0.43 & 1.01 \\
\hline 103.6 & 0.11 & - & - & 0.02 & 1.09 \\
\hline 103.5 & 0.14 & - & - & 0.015 & 1.12 \\
\hline 103.9 & 0.19 & - & - & 0.007 & 1.17 \\
\hline 99.2 & 0.31 & 0.001 & 0.999 & 0.003 & 1.43 \\
\hline
\end{tabular}


Table D.2.a Vapor-liquid equilibria of $\mathrm{MMA}-\mathrm{CO}_{2}$ at $35^{\circ} \mathrm{C}$

\begin{tabular}{c|c|c|c|c|c}
\hline $\mathrm{P}[\mathrm{bar}]$ & $\mathrm{w}_{\text {Sty }}[\mathrm{L}]$ & $\mathrm{w}_{\text {Sty }}[\mathrm{V}]$ calc & $\mathrm{w}_{\mathrm{CO}_{2}}[\mathrm{~V}]$ calc & $\mathrm{K}_{\text {Sty }}$ & $\mathrm{K}_{\mathrm{CO}_{2}}$ \\
\hline \hline 68.4 & 0.06 & 0.009 & 0.991 & 0.15 & 1.05 \\
\hline 65.6 & 0.13 & 0.014 & 0.986 & 0.10 & 1.10 \\
\hline 64.3 & 0.15 & 0.015 & 0.985 & 0.09 & 1.13 \\
\hline 60.2 & 0.24 & 0.016 & 0.984 & 0.06 & 1.2 \\
\hline
\end{tabular}

Table D.2.b Vapor-liquid equilibria for $\mathrm{MMA}-\mathrm{CO}_{2}$ at $45^{\circ} \mathrm{C}$

\begin{tabular}{c|c|c|c|c|c}
\hline $\mathrm{P}[\mathrm{bar}]$ & $\mathrm{w}_{\text {Sty }}[\mathrm{L}]$ & $\mathrm{w}_{\text {Sty }}[\mathrm{V}]$ calc & $\mathrm{w}_{\mathrm{CO}_{2}}[\mathrm{~V}]$ calc & $\mathrm{K}_{\text {Sty }}$ & $\mathrm{K}_{\mathrm{CO}_{2}}$ \\
\hline \hline 79.6 & 0.06 & 0.015 & 0.985 & 0.25 & 0.95 \\
\hline 76.7 & 0.13 & 0.014 & 0.986 & 0.11 & 0.88 \\
\hline 74.7 & 0.15 & 0.014 & 0.986 & 0.09 & 0.86 \\
\hline 71.4 & 0.24 & 0.013 & 0.987 & 0.05 & 0.77 \\
\hline
\end{tabular}

Table D.2.c Vapor-liquid equilibria for $\mathrm{MMA}-\mathrm{CO}_{2}$ at $60{ }^{\circ} \mathrm{C}$

\begin{tabular}{c|c|c|c|c|c}
\hline $\mathrm{P}[$ bar] & $\mathrm{w}_{\text {Sty }}[\mathrm{L}]$ & $\mathrm{w}_{\text {Sty }}[\mathrm{V}]$ calc & $\mathrm{w}_{\mathrm{CO}_{2}}[\mathrm{~V}]$ calc & $\mathrm{K}_{\text {Sty }}$ & $\mathrm{K}_{\mathrm{CO}_{2}}$ \\
\hline \hline 96.7 & 0.06 & 0.014 & 0.986 & 0.23 & 1.05 \\
\hline 95.7 & 0.13 & 0.014 & 0.986 & 0.11 & 0.88 \\
\hline 94 & 0.15 & 0.015 & 0.985 & 0.10 & 0.86 \\
\hline 90.0 & 0.24 & 0.015 & 0.985 & 0.06 & 0.77 \\
\hline
\end{tabular}

Table D.3 Peng-Robinson parameters as used for calculations. Pure component parameters are taken from Poling et al. (2001), binary interaction parameter $\mathrm{k}_{\mathrm{ij}}$ taken from Suppes and McHugh (1989) and Uzun et al. (2005)

\begin{tabular}{c|c|c|c}
\hline parameter & Sty & MMA & $\mathrm{CO}_{2}$ \\
\hline \hline $\mathrm{T}_{\mathrm{c}}[\mathrm{K}]$ & 647.05 & 563.95 & 304.25 \\
\hline $\mathrm{P}_{\mathrm{c}}\left[10^{5} \mathrm{~Pa}\right]$ & 39.9 & 36.8 & 73.8 \\
\hline$\omega[-]$ & 0.257 & 0.317 & 0.225 \\
\hline
\end{tabular}

\begin{tabular}{c|c}
\hline $\mathrm{k}_{\mathrm{Sty}-\mathrm{CO}_{2}}$ & 0.046 \\
\hline
\end{tabular} \begin{tabular}{lll}
\hline $\mathrm{k}_{\mathrm{MMA}-\mathrm{CO}_{2}}$ & 0.033 \\
\hline
\end{tabular}




\section{Appendix E}

Tables E.1 and E.2 give the vapor-liquid composition data for Sty- $\mathrm{CO}_{2}$ and for $\mathrm{MMA}-\mathrm{CO}_{2}$ respectively, at 65.5 bar at different temperatures, calculated with the Peng-Robinson Equation of State. The partition coefficient is defined as the ratio of the monomer concentration in the vapor phase $(y)$ over the monomer concentration in the liquid phase $(x)$, i. e. $\mathrm{K}_{\mathrm{mon}}=\frac{\mathrm{y}}{\mathrm{x}}$. For the pure component parameters used in the Peng-Robinson eos, see Table D.3.

Table E.1 Vapor-liquid composition of Sty- $\mathrm{CO}_{2}$ at 65.5 bar and 35,45 and $60{ }^{\circ} \mathrm{C}$

\begin{tabular}{c|c|c|c|c|c|c|c|c}
\hline \multicolumn{3}{c|}{$35^{\circ} \mathrm{C}$} & \multicolumn{3}{c|}{$45^{\circ} \mathrm{C}$} & \multicolumn{3}{c}{$6{ }^{\circ} \mathrm{C}$} \\
$\mathrm{w}_{\text {Sty }}(\mathrm{x})$ & $\mathrm{w}_{\text {Sty }}(\mathrm{y})$ & $\mathrm{K}_{\text {Sty }}$ & $\mathrm{w}_{\text {Sty }}(\mathrm{x})$ & $\mathrm{w}_{\text {Sty }}(\mathrm{y})$ & $\mathrm{K}_{\text {Sty }}$ & $\mathrm{w}_{\text {Sty }}(\mathrm{x})$ & $\mathrm{w}_{\text {Sty }}(\mathrm{y})$ & $\mathrm{K}_{\text {Sty }}$ \\
\hline 0.31 & 0.007 & 0.02 & 0.63 & 0.006 & 0.009 & 0.67 & 0.005 & 0.007 \\
\hline
\end{tabular}

Table E.2 Vapor-liquid composition of MMA-CO ${ }_{2}$ at 65.5 bar and 35,45 and $60{ }^{\circ} \mathrm{C}$

\begin{tabular}{c|c|c|c|c|c|c|c|c}
\hline \multicolumn{3}{c|}{$35^{\circ} \mathrm{C}$} & \multicolumn{3}{c|}{$45^{\circ} \mathrm{C}$} & \multicolumn{3}{c}{$6{ }^{\circ} \mathrm{C}$} \\
$\mathrm{W}_{\text {MMA }}(\mathrm{x})$ & $\mathrm{W}_{\text {MMA }}(\mathrm{y})$ & $\mathrm{K}_{\text {MMA }}$ & $\mathrm{W}_{\text {MMA }}(\mathrm{x})$ & $\mathrm{w}_{\text {MMA }}(\mathrm{y})$ & $\mathrm{K}_{\text {MMA }}$ & $\mathrm{w}_{\text {MMA }}(\mathrm{x})$ & $\mathrm{w}_{\text {MMA }}(\mathrm{y})$ & $\mathrm{K}_{\text {MMA }}$ \\
\hline \hline 0.13 & 0.01 & 0.11 & 0.40 & 0.01 & 0.03 & 0.54 & 0.01 & 0.01 \\
\hline
\end{tabular}




\section{Appendix F}

Experimentally determined monomer partition coefficient between polymer and $\mathrm{CO}_{2}$. Table F.1 represents the results for Sty-PS-(sc) $\mathrm{CO}_{2}$, Table F.2 shows the results for MMA-PMMA$(\mathrm{sc}) \mathrm{CO}_{2}$

Table F.1 Partition coefficient of Sty between PS and (sc) $\mathrm{CO}_{2}$ [ $\left.\mathrm{kg} \mathrm{PS} / \mathrm{kg}(\mathrm{sc}) \mathrm{CO}_{2}\right]$

\begin{tabular}{c|c|c|c}
\hline $\mathrm{P}$ [bar] & $\mathrm{K}$ at $35{ }^{\circ} \mathrm{C}$ & $\mathrm{K}$ at $45^{\circ} \mathrm{C}$ & $\mathrm{K}$ at $60{ }^{\circ} \mathrm{C}$ \\
\hline \hline 100 & $18 \pm 10$ & $9 \pm 2.2$ & $1.8 \pm 0.1$ \\
\hline 140 & 2 & $2.5 \pm 0.1$ & $1.40 \pm 0.01$ \\
\hline 180 & 1.0 & $1.8 \pm 0.3$ & $1.00 \pm 0.02$ \\
\hline
\end{tabular}

Table F.2 Partition coefficient of MMA between PMMA and (sc) $\mathrm{CO}_{2}\left[\mathrm{~kg} \mathrm{PMMA} / \mathrm{kg}(\mathrm{sc}) \mathrm{CO}_{2}\right]$

\begin{tabular}{c|c|c|c}
\hline $\mathrm{P}$ [bar] & $\mathrm{K}$ at $35{ }^{\circ} \mathrm{C}$ & $\mathrm{K}$ at $45^{\circ} \mathrm{C}$ & $\mathrm{K}$ at $60{ }^{\circ} \mathrm{C}$ \\
\hline \hline 100 & $0.29 \pm 0.002$ & $0.25 \pm 0.02$ & $0.24 \pm 0.01$ \\
\hline 140 & $0.38 \pm 0.01$ & $0.29 \pm 0.02$ & $0.32 \pm 0.01$ \\
\hline 180 & $0.35 \pm 0.01$ & $0.3 \pm 0.02$ & $0.28 \pm 0.01$ \\
\hline
\end{tabular}

The partition coefficient for the distribution of monomer between $\mathrm{CO}_{2}$ swollen polymer and $\mathrm{CO}_{2}$ has been calculated with Equation F.1

$\frac{(\text { mol mon })^{\text {polymer }}}{(\text { mol mon })^{\mathrm{CO}_{2}}}$

The monomer concentration in the polymer phase followed from a mass balance of the monomer, see Equation F.2.

$(\mathrm{mol} \mathrm{mon})^{\text {added }}=(\mathrm{mol} \mathrm{mon})^{\mathrm{CO}_{2}}+(\mathrm{mol} \mathrm{mon})^{\text {polymer }}$

The amount of moles of monomer added to the autoclave was accurately known (see section 'Materials and methods'). The monomer concentration in the $(\mathrm{sc}) \mathrm{CO}_{2}$ phase was measured. Without any addition of monomer to the polymer, the analysis of the $(\mathrm{sc}) \mathrm{CO}_{2}$ showed that 
there was already monomer present in the polymer. The calculated partition coefficient, see Equation F.1, was set as starting value in the determination of the amount of monomer present in the polymer phase. The newly found number of monomer in the polymer phase was then added to the number found from the measurement and a new partition coefficient was determined. This iteration was repeated until a constant value for the partition coefficient had been found. 



\title{
Chapter 4
}

\section{Mass transport phenomena in the supercritical carbon dioxide extraction of residual monomer from latex products}

\begin{abstract}
The mechanism of mass transport involved in the extraction of residual monomer from a latex product with supercritical carbon dioxide $\left(\mathrm{scCO}_{2}\right)$ has been studied. Monomer transport was found to be governed by the shuttle effect, based on Brownian motion of the polymer particles to and from the water/scCO $\mathrm{CO}_{2}$ interface. Surface Gibbs free energy considerations were used to predict the position of the particles at the $(\mathrm{sc}) \mathrm{CO}_{2} / \mathrm{H}_{2} \mathrm{O}$ interface. The main resistance against monomer transfer from the polymer particles to the $(\mathrm{sc}) \mathrm{CO}_{2}$ phase has been demonstrated to be located inside the polymer particles.
\end{abstract}

\section{Introduction}

Latex is a colloidally stable dispersion of submicron $(\sim 100 \mathrm{~nm})$ polymer particles in water. The polymer particles contain residual monomer due to incomplete conversion. Supercritical or high-pressure carbon dioxide $\left((\mathrm{sc}) \mathrm{CO}_{2}\right)$ has been studied as extraction medium to reduce the residual monomer level in polymer based products. The present work focuses on the monomer transport mechanism from the submicron polystyrene or polymethyl methacrylate particles to the $(\mathrm{sc}) \mathrm{CO}_{2}$ phase.

Two mechanisms for transfer of monomer from latex particles to $(\mathrm{sc}) \mathrm{CO}_{2}$ operate in parallel. The resistance in series approach, i.e. solid-to-liquid-to-fluid (SLF) mass transfer, as well as a direct solid-to-fluid (SF) mass transfer model, also referred to as the shuttle effect (Beenackers and van Swaaij, 1993, Vinke et al., 1993). 
In the resistance in series approach, the monomer diffuses out of the polymer particles through the water $\left(\mathrm{H}_{2} \mathrm{O}\right)$ phase into the $(\mathrm{sc}) \mathrm{CO}_{2}$ phase. The main resistance against mass transfer is located in the $\mathrm{H}_{2} \mathrm{O}$ phase due to the low monomer solubility (Zhang and Ray, 1997), Figure 1.

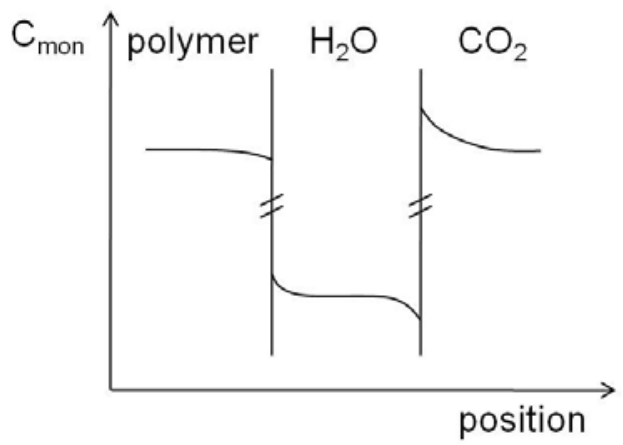

Figure 1 The resistance in series mass transport approach. $\mathrm{C}_{\mathrm{mon}}$ is the monomer concentration in the respective phases.

Describing the diffusion of monomer through the three phases, i.e. the polymer particles, the $\mathrm{H}_{2} \mathrm{O}$ phase and the $\mathrm{CO}_{2}$ phase, the film model has been used. The overall molar mass transfer flux of the monomer $\left(\phi_{\mathrm{mon}}\right)$ is expressed in Equation 1.

$$
\begin{gathered}
\phi_{\text {mon }}=\left[\left(\frac{1}{\mathrm{k}_{\mathrm{m}}^{\mathrm{P}}}\right)_{\mathrm{P} \text { phase }}+\left(\frac{1}{\mathrm{k}_{\mathrm{m}}^{\mathrm{H}_{2} \mathrm{O}} * \mathrm{~K}_{\mathrm{mon}}^{\text {polymer } / \mathrm{H}_{2} \mathrm{O}}}\right)_{\mathrm{H}_{2} \mathrm{O} \text { phase }}+\left(\frac{1}{\mathrm{k}_{\mathrm{m}}^{\mathrm{CO}_{2}} * \mathrm{~K}_{\mathrm{mon}}^{\mathrm{H}_{2} \mathrm{O} / \mathrm{CO}_{2}}}\right)_{\mathrm{CO}_{2} \text { phase }}\right]^{-1} * \mathrm{a}_{\mathrm{p}} * \\
*\left(\mathrm{C}_{\mathrm{m}}^{\mathrm{P}}-\frac{\mathrm{C}_{\mathrm{m}}^{\mathrm{CO}_{2}}}{\mathrm{~K}_{\mathrm{mon}}^{\text {polymer } / \mathrm{H}_{2} \mathrm{O}} * \mathrm{~K}_{\mathrm{mon}}^{\mathrm{H}_{2} \mathrm{O} / \mathrm{CO}_{2}}}\right)
\end{gathered}
$$

where $\mathrm{k}_{\mathrm{m}}^{\mathrm{i}}, \mathrm{K}_{\mathrm{mon}}^{\mathrm{i} / \mathrm{j}}$ and $\mathrm{a}_{\mathrm{p}}$ stand for the monomer mass transfer coefficient in phase $\mathrm{i}$, the monomer partition coefficient between phase $\mathrm{i}$ and phase $\mathrm{j}$ and the specific mass transfer area of the polymer particles, respectively.

In the SF mass transfer approach, the polymer particles move through the $\mathrm{H}_{2} \mathrm{O}$ phase towards the $\mathrm{H}_{2} \mathrm{O} / \mathrm{CO}_{2}$ interface. The monomer diffuses out of the polymer particles directly into the $(\mathrm{sc}) \mathrm{CO}_{2}$ phase, see Figure 2. 


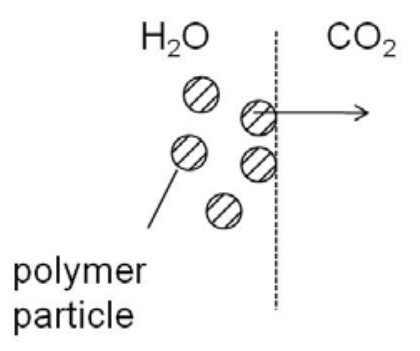

Figure 2 The solid-to-fluid mass transfer approach (shuttle mechanism).

The dimension of the polymer particles, allows for Brownian motion in water and consequently can reside for some time at the $\mathrm{H}_{2} \mathrm{O} /(\mathrm{sc}) \mathrm{CO}_{2}$ interface (Brilman et al., 1998). At the $\mathrm{H}_{2} \mathrm{O} /(\mathrm{sc}) \mathrm{CO}_{2}$ interface the polymer particle is in direct contact with the $(\mathrm{sc}) \mathrm{CO}_{2}$ phase allowing direct diffusional transport of the monomer from the polymer particles to the (sc) $\mathrm{CO}_{2}$ phase. Alper et al. (1980) used the boundary layer model to describe mass transfer by the shuttle effect. After a certain contact time the particles near the interface have lost part of the initially present monomer. Dumont and Delmes (2003) emphasize that in many situations the contact time between particle and fluid is so short that the steady-state concentration gradient of the particles containing film does not have enough time to develop. Therefore, only unsteady-state models can be used to describe mass transfer.

Concentration leveling of the monomer in the polymer phase is related to time or the Fourier number, see Equation 2 and Figure 3.

Fo $=\frac{\mathrm{D}_{\mathrm{m}}^{\mathrm{p}} * \mathrm{t}_{\text {contact, }} \mathrm{p}}{\mathrm{d}_{\text {particle }}^{2}}$ 


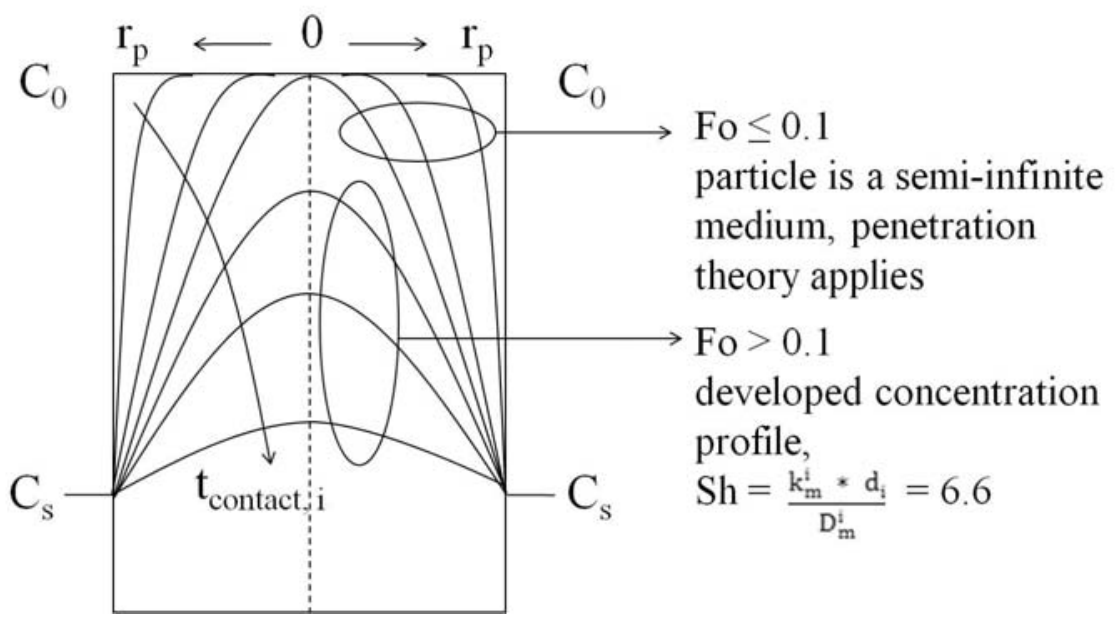

Figure 3 Concentration leveling of the monomer in a polymer particle. $r_{p}$ is the polymer particle radius, $\mathrm{C}_{0}$ the initial monomer concentration in the polymer particle (at $\mathrm{t}_{\text {contact }}=0$ ), i.e. just before arriving at the $\mathrm{H}_{2} \mathrm{O} / \mathrm{CO}_{2}$ interface, $\mathrm{C}_{\mathrm{s}}$ the monomer concentration at the polymer particle surface, directly after arriving on the $\mathrm{H}_{2} \mathrm{O} / \mathrm{CO}_{2}$ interface.

Chon et al. (2005) suggest that the residence time of polymer particles at the $\mathrm{H}_{2} \mathrm{O} /(\mathrm{sc}) \mathrm{CO}_{2}$ interface $\left(t_{\text {contact, }} \mathrm{P}\right)$ can be regarded in terms of Brownian motion of the polymer particles in the water phase, see Equation 3. Chon et al. (2005) used $\mathrm{Al}_{2} \mathrm{O}_{3}$ nanoparticles to increase the heat conductivity of water and validated that Brownian motion of the nanoparticles is the key mechanism for thermal conductivity enhancement. Comparable observations are reported by other authors (Jang and Choi, 2004). $t_{\text {contact, } P}$ can be described as the ratio of the length scale of the interfacial region $(\Delta s)$ and the Brownian velocity of of the polymer particles $\left(\mathrm{v}_{\mathrm{Br}}\right)$.

$\mathrm{t}_{\text {contact, } \mathrm{p}}=\frac{\Delta \mathrm{s}}{\mathrm{v}_{\mathrm{Br}}}$

The length scale of the interfacial region is assumed to be $10 \mu \mathrm{m}$ (Kemmere et al., 2002); $\Delta s$ is of the same order of magnitude. The Brownian velocity $\left(v_{B r}\right)$ follows from Equation 4.

$\mathrm{v}_{\mathrm{Br}}=\frac{\mathrm{k}_{\mathrm{b}} * \mathrm{~T}}{3 * \pi * \eta * \mathrm{~d}_{\text {particle }} * \mathrm{l}_{\mathrm{BF}}}$

where $k_{b}$ stands for the Boltzman constant, $\eta$ for the water viscosity and $I_{B F}$ for the mean free path of the particle in water $\left(\mathrm{l}_{\mathrm{H}_{2} \mathrm{O}}=0.17 \mathrm{~nm}\right.$ (Jang and Choi, 2004)). 
For Fo $<0.1$, mass transport in the polymer particles can be regarded to be in a semi-infinite medium. Then the penetration theory applies for mass transport, Equation 5 (Welty et al., 2001, Bird et al., 2002).

$\mathrm{k}_{\mathrm{m}}^{\mathrm{p}}=2 * \sqrt{\frac{\mathrm{D}_{\mathrm{m}}^{\mathrm{p}}}{\pi * \mathrm{t}_{\text {contact, } \mathrm{p}}}}$

For Fo > 0.1, intraparticle mass transport can be described with Equation 6 (van den Akker and Mudde, 1997), see Figure 3.

$\mathrm{Sh}=\frac{\mathrm{k}_{\mathrm{m}}^{\mathrm{i}} * \mathrm{~d}_{\text {particle }}}{\mathrm{D}_{\mathrm{m}}^{\mathrm{i}}}=6.6$

The mass transfer resistance depends on the specific area of the $\mathrm{H}_{2} \mathrm{O} /(\mathrm{sc}) \mathrm{CO}_{2}$ interface. Joly-Vuillemin and Bellefon (1999) suggest that the polymer particles partially cover the $\mathrm{H}_{2} \mathrm{O} /(\mathrm{sc}) \mathrm{CO}_{2}$ interface. The effective specific mass transfer area is then defined as:

$\mathrm{a}_{\mathrm{eff}}(\mathrm{SF})=\mathrm{a}_{\mathrm{ij}} * \theta \quad$ for the shuttle effect

$\mathrm{a}_{\mathrm{eff}}(\mathrm{SLF})=\mathrm{a}_{\mathrm{ij}}{ }^{*}(1-\theta) \quad$ for the SLF approach

Note that $\theta_{\max }$ is 0.74 , i.e. the maximum fractional surface coverage by spherical particles in a three dimensional closest packing.

As mentioned earlier the SLF model is diffusion limited due to the low monomer solubility in water (Zhang and Ray, 1997). The partitioning of monomer between the particles and the water phase is very low towards the water phase, $\mathrm{K}_{\text {mon }}^{\text {polymer } / \mathrm{H}_{2} \mathrm{O}}$ is in the order of magnitude of $10^{-3} \mathrm{~kg}$ polymer $/ \mathrm{kg} \mathrm{H} \mathrm{H}_{2} \mathrm{O}$ (Kemmere et al. 2005, González et al., 2007). In comparison with the SF mass transfer model, phase equilibrium of monomer between the particles and (sc) $\mathrm{CO}_{2}$ cannot be reached within a short time. The shuttle effect is therefore dominating the mass transfer. The mass transfer-in-series contribution is assumed to be negligible.

\section{Interfacial properties}

Interfacial properties, more specifically interfacial tension between the phases involved is an important quantity associated with mass transfer. The interfacial tension, related to the specific interfacial Gibbs energy, is the excess Gibbs energy per unit area due to the 
formation of an interface (Van Krevelen, 1997). The interfacial tension is closely related to the cohesion energy of a system (O'Neill et al., 1998).

In 1907, Pickering observed that solid particles could adhere to a liquid-liquid interface thereby stabilizing emulsions (Pickering, 1907). Finkle et al. (1923) suggested the emulsions were stabilized because the particles were partially wetted by the two liquids involved. The ability of solid particles to adhere to a liquid-liquid interface has been described by Colver et al. (2006) in terms of energy contributions.

Torza and Mason (1970) reported a thermodynamic approach to predict the morphology of two immiscible liquids suspended in a liquid immiscible with both other liquids. Based on the pioneering work of Torza and Mason (1970), numerous authors were able to thermodynamically predict the morphology of composite latex systems, see e.g. Sundberg et al. (1990), Chen et al. (1991) and Sundberg and Sundberg (1993).

In all cases reported, the thermodynamically preferred morphology is the one that has the lowest interfacial Gibbs free energy. The driving force to obtain the preferred morphology at fixed pressure and temperature, the Gibbs free energy change $(\Delta G)$ of the process, can be expressed as (Hiemenz and Rajagopalan, 1997):

$\Delta \mathrm{G}=\sum_{\mathrm{i}} \gamma_{\mathrm{i}} * \mathrm{~A}_{\mathrm{i}}-\gamma_{0} * \mathrm{~A}_{0}$

where $\gamma_{i}, A_{i}, \gamma_{0}$ and $A_{0}$ stand for the interfacial tension of the $i^{\text {th }}$ interface and its corresponding interfacial area, the interfacial tension of the original polymer suspended in water and the corresponding interfacial area, respectively.

In the present work, the position of polystyrene (PS) and polymethyl methacrylate (PMMA) latex particles in a biphasic $(\mathrm{sc}) \mathrm{CO}_{2} / \mathrm{H}_{2} \mathrm{O}$ environment has been predicted using the theory of Torza and Mason (1970) as well as the theory of Colver et al. (2006).

Torza and Mason (1970) defined the spreading coefficients $\left(S_{i}\right)$ of a three-phase system, which yields the same result as an analysis based on minimizing the Gibbs free energy, as:

$S_{i}=\gamma_{j k}-\left(\gamma_{i j}+\gamma_{i k}\right)$ 
By convention, phase 1 must be the phase for which $\gamma_{12}>\gamma_{23}$, so that $S_{1}<0$. Then complete engulfment, i.e. core-shell morphology, occurs when $S_{2}<0$ and $S_{3}>0$. If $S_{2}<0$ and $S_{3}<0$, the engulfment is only partial and leads to hemispherical morphologies. When $S_{2}>0$ and $S_{3}<0$, separated structures are preferred. Removing the restriction that $\gamma_{12}>$ $\gamma_{13}$, a fourth less common morphology can be predicted as a special case of core-shell, i.e. inverted core-shell, when $S_{1}>0, S_{2}<0$ and $S_{3}<0$. Figure 4 shows all possible structures and their spreading coefficients.

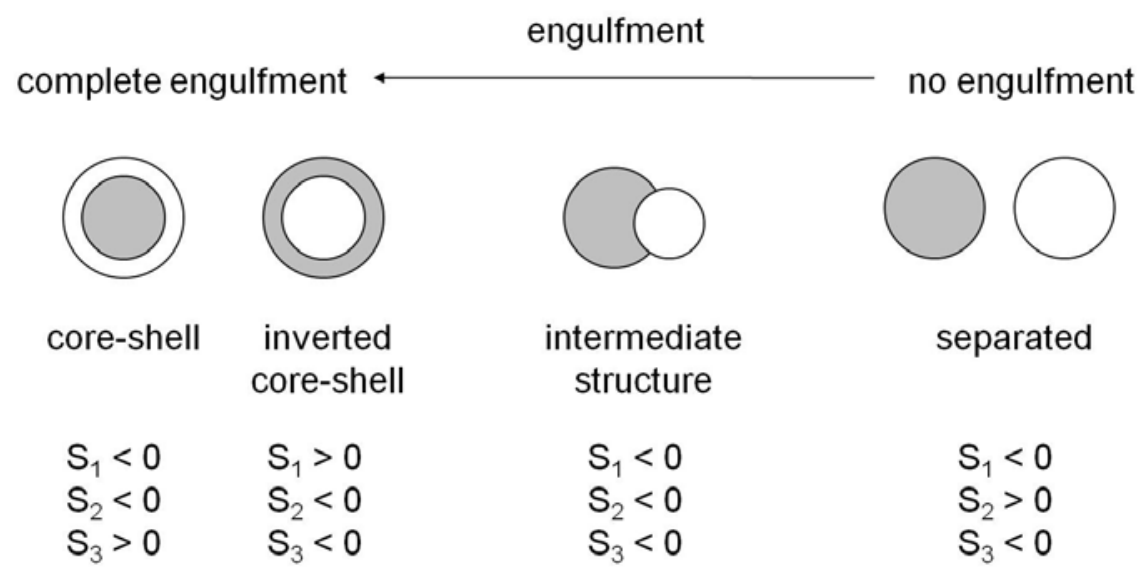

Figure 4 Engulfment and spreading coefficients according to the theory of Torza and Mason (1970).

In the present work, two systems have been investigated; a polystyrene (PS) latex and a polymethyl methacrylate (PMMA) latex are both submitted to extraction with (sc) $\mathrm{CO}_{2}$. Interfacial tension between polymer particles and $(\mathrm{sc}) \mathrm{CO}_{2}$ decreases with increasing pressure due to the adsorption of (sc) $\mathrm{CO}_{2}$ at the interface (Jaeger et al., 1996, Otake et al., 1994).

Table 1 gives the interfacial tensions between $\mathrm{H}_{2} \mathrm{O}$ and $\mathrm{CO}_{2}$ (Tewes and Boury, 2004, Owens and Wendt, 1969, da Rocha et al., 2001, Kvamme et al., 2007, Dhanuka et al., 2006), $\mathrm{H}_{2} \mathrm{O}$ and polymer (Sundberg et al., 1990, Webber et al., 1997) as well as between $\mathrm{CO}_{2}$ and polymer at 100 bar and $35{ }^{\circ} \mathrm{C}$, without any surfactant in either phase. The spreading coefficients are also collected in Table 1. The interfacial tension between $\mathrm{CO}_{2}$ and polymer has been calculated by fitting data of Otake et al. (2004), who correlated the $\mathrm{CO}_{2}$ density to the interfacial tension between $\mathrm{CO}_{2}$ and $\mathrm{PS}$ as well as between $\mathrm{CO}_{2}$ and PMMA. 
The spreading coefficients have been calculated according to Torza's theory (Torza and Mason, 1970). To fulfill the condition $\gamma_{12}>\gamma_{23}, \mathrm{PS}, \mathrm{H}_{2} \mathrm{O}$ and $\mathrm{CO}_{2}$ were designated as phase $1,2,3$ respectively. In case of PMMA, $\mathrm{CO}_{2}$ was taken as phase 1 and PMMA as phase 3 .

Table 1 Interfacial tensions at 100 bar and $35{ }^{\circ} \mathrm{C}$ between $\mathrm{H}_{2} \mathrm{O}$ and $\mathrm{CO}_{2}$ (Kvamme et al., 2007 et al.), between $\mathrm{H}_{2} \mathrm{O}$ and polymer (Sundberg et al., 1990, Webber et al., 1997) and between $\mathrm{CO}_{2}$ and polymer (Otake et al., 2004). The spreading coefficients have been calculated with the Torza theory (Torza and Mason, 1970). The systems do not contain surfactant molecules.

\begin{tabular}{l|c|c|c|c|c|c}
\hline & \multicolumn{3}{|c|}{ Interfacial tensions [mN.m ${ }^{-1}$ ] } & \multicolumn{3}{c}{ Spreading coefficients } \\
polymer & $\gamma_{\mathrm{CO}_{2}-\mathrm{H}_{2} \mathrm{O}}$ & $\gamma_{\mathrm{CO}_{2}-\text { polymer }}$ & $\gamma_{\mathrm{H}_{2} \mathrm{O}-\text { polymer }}$ & $\mathrm{S}_{1}$ & $\mathrm{~S}_{2}$ & $\mathrm{~S}_{3}$ \\
\hline \hline PS & 30 & 5.4 & 40.1 & -15.5 & -64.7 & 4.7 \\
\hline PMMA & 30 & 5.1 & 25.4 & -9.7 & -50.3 & -0.5 \\
\hline
\end{tabular}

The calculated spreading coefficients predict complete wetting of polymer particles in $\mathrm{CO}_{2}$ for PS, i.e. $\mathrm{CO}_{2}$ completely wets the polymer particles, and an intermediate structure, i. e. the polymer particles are partially wetted by the $\mathrm{CO}_{2}$ and partially by the $\mathrm{H}_{2} \mathrm{O}$, for PMMA.

As mentioned before, latex is a dispersion of submicron polymer particles in water, colloidally stabilized by surface active agents. Surfactants consist of both a hydrophilic part and a hydrophobic part. Upon addition of a surfactant to a system of two immiscible phases, the surface active agent is adsorbed at the interface. When the surfactant molecules replace molecules from the original interface, the interaction across the interface is now between the hydrophilic group of the surfactant and the polar phase on one side of the interface and between the hydrophobic group of the surfactant and the apolar phase on the other side of the interface. The newly formed interactions are much stronger than the original interaction between the dissimilar polar and apolar molecules, consequently the interfacial tension is significantly reduced by the presence of the surfactant (Rosen, 2004, Chattoraj, 2001). Rosen (2004) also compared several surfactants in the performance of reducing the interfacial tension. Every type of surfactant, i.e. non-ionic, ionic or electrosteric, has a certain efficiency in adsorbing at the interface between two phases, depending on the 
investigated system, thereby decreasing the interfacial tension. Harrison et al. (1996) also reported about the effect of different surfactants on the interfacial tension between two phases.

The latex systems investigated in the present work are stabilized by sulfate group containing surfactants. For simplicity, sodium dodecyl sulfate (SDS) has been chosen as surfactant to perform the calculations of Torza (Torza and Mason, 1970). Table 2 shows the interfacial tensions between $\mathrm{H}_{2} \mathrm{O} / \mathrm{SDS}$ and $\mathrm{CO}_{2}$ (Dhanuka et al., 2006), $\mathrm{H}_{2} \mathrm{O} / \mathrm{SDS}$ and polymer (Sundberg et al., 1990, Sundberg and Sundberg, 1993) and $\mathrm{CO}_{2}$ and polymer, as well as the spreading coefficients. Otake et al. (2004) reported about the interfacial tension at the $\mathrm{CO}_{2} /$ polymer interface in the presence of tetradecanoic acid (MA), demonstrating the surface activity of carboxylic surfactants. At the same $\mathrm{CO}_{2}$ density, the interfacial tension between $\mathrm{CO}_{2}$ and polymer/MA is approximately half the value of the interfacial tension between $\mathrm{CO}_{2}$ and polymer without surfactant. Addition of SDS to the system $\mathrm{CO}_{2}$ /polymer will also decrease the interfacial tension as compared to the system without surfactant. However, due to the lack of any experimental data, the interfacial tension of the surfactant free system is used in the calculation of the spreading coefficients. ${ }^{1}$

In order to fulfill the requirement $\gamma_{12}>\gamma_{23}$, polymer, $\mathrm{H}_{2} \mathrm{O}$ and $\mathrm{CO}_{2}$ were designated as phase 1,2 and 3 , respectively.

Table 2 Interfacial tensions at 100 bar and $35^{\circ} \mathrm{C}$ between $\mathrm{H}_{2} \mathrm{O} / \mathrm{SDS}$ and $\mathrm{CO}_{2}$ (Dhanuka et al., 2006), between $\mathrm{H}_{2} \mathrm{O} / \mathrm{SDS}$ and polymer (Sundberg et al., 1990, Sundberg and Sundberg, 1993) and between $\mathrm{CO}_{2}$ and polymer (Otake et al., 2004). The spreading coefficients have been calculated with the Torza theory (Torza and Mason, 1970). The water systems contain sodium dodecyl sulfate (SDS) as surfactant.

\begin{tabular}{l|c|c|c|c|c|c}
\hline & \multicolumn{3}{|c|}{ Interfacial tensions [mN.m } & \multicolumn{3}{c}{ Spreading coefficients } \\
polymer & $\gamma_{\mathrm{CO}_{2}-\mathrm{H}_{2} \mathrm{O} / \mathrm{SDS}}$ & $\gamma_{\mathrm{CO}_{2}-\text { polymer }}$ & $\gamma_{\text {polymer }-\mathrm{H}_{2} \mathrm{O} / \mathrm{SDS}}$ & $\mathrm{S}_{1}$ & $\mathrm{~S}_{2}$ & $\mathrm{~S}_{3}$ \\
\hline \hline PS & 4 & 5.4 & 13.2 & -14.6 & -11.8 & 3.8 \\
\hline PMMA & 4 & 5.1 & 10.7 & -11.8 & -9.6 & 1.6 \\
\hline
\end{tabular}

\footnotetext{
${ }^{1}$ The interfacial tension between $\mathrm{CO}_{2}$ and polymer without surfactant is already so small, that using this value instead of the slightly smaller interfacial tension between $\mathrm{CO}_{2}$-polymer/surfactant, does not change the result of the calculation of the spreading coefficients. In both cases, the same morphology has been predicted.
} 
The calculated spreading coefficients predict complete wetting of the polymer particles in $\mathrm{CO}_{2}$ for both PS and PMMA.

The position of the polymer particles in the $\mathrm{CO}_{2} / \mathrm{H}_{2} \mathrm{O}$ interfacial region predicted by the theory of Torza (Torza and Mason, 1970) was verified by the Pickering stabilization theory (Colver et al., 2006). Colver et al. (2006) predict the polymer particle position with respect to a flat liquid-liquid interface and relative to the centre of the spherical polymer particle defining a dimensionless number, $\mathrm{z}_{0}$, see Equation 11 and Figure 5.

$\mathrm{z}_{0}=\frac{\mathrm{z}}{\mathrm{R}}$

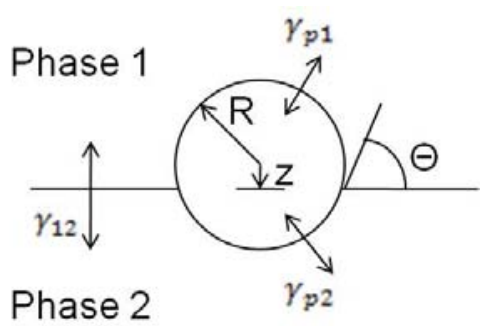

Figure 5 Schematic representation for a sphere at a liquid-liquid interface.

The total Gibbs energy the system experiences is the sum of different energy contributions of the three interfaces (polymer-phase 1, polymer-phase 2, phase 1-phase 2). Division of the total Gibbs energy by $\mathrm{k}_{\mathrm{b}} * \mathrm{~T}$, results in the dimensionless total energy of the system, see Equation 12.

$\mathrm{G}_{0}=\left[\frac{\pi * \mathrm{R}^{2} * \gamma_{21}}{\mathrm{k}_{\mathrm{b}} * \mathrm{~T}}\right] *\left[\mathrm{z}_{0}^{2}+2 *(\mathrm{a}-\mathrm{b}) * \mathrm{z}_{0}+2 * \mathrm{a}+2 * \mathrm{~b}-1\right]$

with $\mathrm{a}=\frac{\gamma_{\mathrm{p} 1}}{\gamma_{21}}$ and $\mathrm{b}=\frac{\gamma_{\mathrm{p} 2}}{\gamma_{21}}$. The minimum energy follows from the first derivative of $\mathrm{G}_{0}$ with respect to $z_{0}$, see Equation 13 .

$\frac{\mathrm{dG}_{0}}{\mathrm{dz}_{0}}=2 * \mathrm{z}_{0}+2 *(\mathrm{a}-\mathrm{b})=0$

The equilibrium position of the particle is, see Equation 14.

$\mathrm{z}_{0}^{\min }=\mathrm{b}-\mathrm{a}$

There are three possible scenarios: 
$\mathrm{z}_{0}^{\min } \geq 1 \quad$ the particle will be completely in phase 1

$\mathrm{z}_{0}^{\min } \leq-1 \quad$ the particle will be completely in phase 2

$-1<\mathrm{z}_{0}^{\min }<1 \quad$ the particle will adhere at the interface of phase 1 and 2

The interfacial tensions between polymer and $\mathrm{CO}_{2}$, polymer and $\mathrm{H}_{2} \mathrm{O}$ as well as between $\mathrm{CO}_{2}$ and $\mathrm{H}_{2} \mathrm{O}$ at 100 bar and $35{ }^{\circ} \mathrm{C}$ (see also Table 1) are collected in Table 3. These interfacial tensions have been used in the calculation of the equilibrium position and energy of the polymer particle following the theory of Colver et al. (2006). $\mathrm{CO}_{2}$ is designated as phase $1, \mathrm{H}_{2} \mathrm{O}$ as phase 2 . The system does not contain a surface active agent. The polymer particles have a diameter of $100 \mathrm{~nm}$.

Table 3 Interfacial tensions at 100 bar and $35{ }^{\circ} \mathrm{C}$ between $\mathrm{H}_{2} \mathrm{O}$ and $\mathrm{CO}_{2}$ (Kvamme et al., 2007 et al.), between $\mathrm{H}_{2} \mathrm{O}$ and polymer (Sundberg et al., 1990, Webber et al., 1997) and between $\mathrm{CO}_{2}$ and polymer (Otake et al., 2004). The equilibrium position of a polymer particle in a $\mathrm{CO}_{2}-\mathrm{H}_{2} \mathrm{O}$ system at 100 bar and $35{ }^{\circ} \mathrm{C}$ and the energy of the system have been calculated with the theory of Colver et al. (2006). There are no surfactants present in the system.

\begin{tabular}{l|c|c|c|c|c|c|c}
\hline & \multicolumn{4}{|c|}{ Interfacial tensions $\left[\mathrm{mN} \cdot \mathrm{m}^{-1}\right]$} & \multicolumn{4}{l}{$\begin{array}{l}\text { Equilibrium position of the polymer } \\
\text { particle [-] and energy of the } \\
\text { system [-] }\end{array}$} \\
polymer & $\gamma_{\text {polymer- } \mathrm{CO}_{2}}$ & $\gamma_{\text {polymer }-\mathrm{H}_{2} \mathrm{O}}$ & $\gamma_{\mathrm{CO}_{2}-\mathrm{H}_{2} \mathrm{O}}$ & $\mathrm{a}$ & $\mathrm{b}$ & $\mathrm{z}_{0}$ & $\mathrm{G}_{0}\left[10^{6}\right]$ \\
\hline \hline PS & 5.4 & 40.1 & 30 & 0.18 & 1.34 & 1.16 & 38.5 \\
\hline PMMA & 5.1 & 25.4 & 30 & 0.17 & 0.85 & 0.68 & 31.9 \\
\hline
\end{tabular}

For PS, the theory of Colver et al. (2006) predicts that the PS particles will be completely wetted by the $\mathrm{CO}_{2}$ phase $\left(\mathrm{z}_{0} \geq 1\right)$. This result is comparable to the prediction of the position of the PS in the interfacial region with the theory of Torza and Mason (1970). The PMMA particles will adhere at the $\mathrm{CO}_{2}-\mathrm{H}_{2} \mathrm{O}$ interface $\left(-1 \leq \mathrm{z}_{0} \leq 1\right)$ as has also been predicted by the theory of Torza and Mason (1970).

Table 4 shows the results of analogous calculations using the interfacial tensions between polymer and $\mathrm{CO}_{2}$, polymer and $\mathrm{H}_{2} \mathrm{O}$ /SDS as well as between $\mathrm{CO}_{2}$ and $\mathrm{H}_{2} \mathrm{O} /$ SDS. 
Table 4 Interfacial tensions at 100 bar and $35{ }^{\circ} \mathrm{C}$ between $\mathrm{H}_{2} \mathrm{O} / \mathrm{SDS}$ and $\mathrm{CO}_{2}$ (Dhanuka et al., 2006), between $\mathrm{H}_{2} \mathrm{O} / \mathrm{SDS}$ and polymer (Sundberg et al., 1990, Sundberg and Sundberg, 1993) and between $\mathrm{CO}_{2}$ and polymer (Otake et al. 2004). The equilibrium position of a polymer particle in a $\mathrm{CO}_{2}-\mathrm{H}_{2} \mathrm{O}$ system at 100 bar and $35^{\circ} \mathrm{C}$ and the energy of the system have been calculated with the theory of Colver et al. (2006). The water systems contain sodium dodecyl sulfate (SDS) as surfactant.

\begin{tabular}{|c|c|c|c|c|c|c|c|}
\hline \multirow[b]{2}{*}{ polymer } & \multicolumn{3}{|c|}{ Interfacial tensions $\left[\mathrm{mN} \cdot \mathrm{m}^{-1}\right]$} & \multicolumn{4}{|c|}{$\begin{array}{l}\text { Equilibrium position of the } \\
\text { polymer particle [-] and energy of } \\
\text { the system [-] }\end{array}$} \\
\hline & $\gamma_{\text {polymer }-\mathrm{CO}_{2}}$ & $\gamma_{\text {polymer }-\mathrm{H}_{2} \mathrm{O}+S D S}$ & $\gamma_{\mathrm{CO}_{2}-\mathrm{H}_{2} \mathrm{O}+\mathrm{SDS}}$ & a & $b$ & $\mathrm{z}_{0}$ & $\mathrm{G}_{0}\left[10^{6}\right]$ \\
\hline PS & 5.4 & 13.2 & 4 & 1.35 & 3.3 & 1.95 & 33.2 \\
\hline PMMA & 5.1 & 10.7 & 4 & 1.28 & 2.68 & 1.4 & 36.5 \\
\hline
\end{tabular}

Again the equilibrium position predicted with the theory of Colver et al. (2006) corresponds to that predicted with the theory of Torza and Mason (1970). Using interfacial tensions given in Table 4 predicts completely wetted particles with $\mathrm{CO}_{2}$ for polystyrene as well as for polymethyl methacrylate $\left(z_{0} \geq 1\right)$.

Interesting is that Colver et al. (2006) suggest that the Gibbs energy necessary to remove the particle from its equilibrium position has a value in the order of $10^{6 *} \mathrm{k}_{\mathrm{b}}{ }^{*} \mathrm{~T}$, meaning that the polymer particle is irreversibly trapped at its equilibrium position and cannot escape via simple Brownian motion. Figure 6 clarifies this suggestion graphically for a PMMA particle in a $\mathrm{CO}_{2}-\mathrm{H}_{2} \mathrm{O}$ system at 100 bar and $35^{\circ} \mathrm{C}$ without surfactant. The respective energy barriers have been calculated according to Equations 15 and 16.

$$
\begin{aligned}
& \Delta \mathrm{G}_{1}=\mathrm{G}_{0}\left(\mathrm{z}_{0}=1\right)-\mathrm{G}_{0}\left(\mathrm{z}_{0}=\mathrm{b}-\mathrm{a}\right) \\
& \Delta \mathrm{G}_{2}=\mathrm{G}_{0}\left(\mathrm{z}_{0}=-1\right)-\mathrm{G}_{0}\left(\mathrm{z}_{0}=\mathrm{b}-\mathrm{a}\right)
\end{aligned}
$$




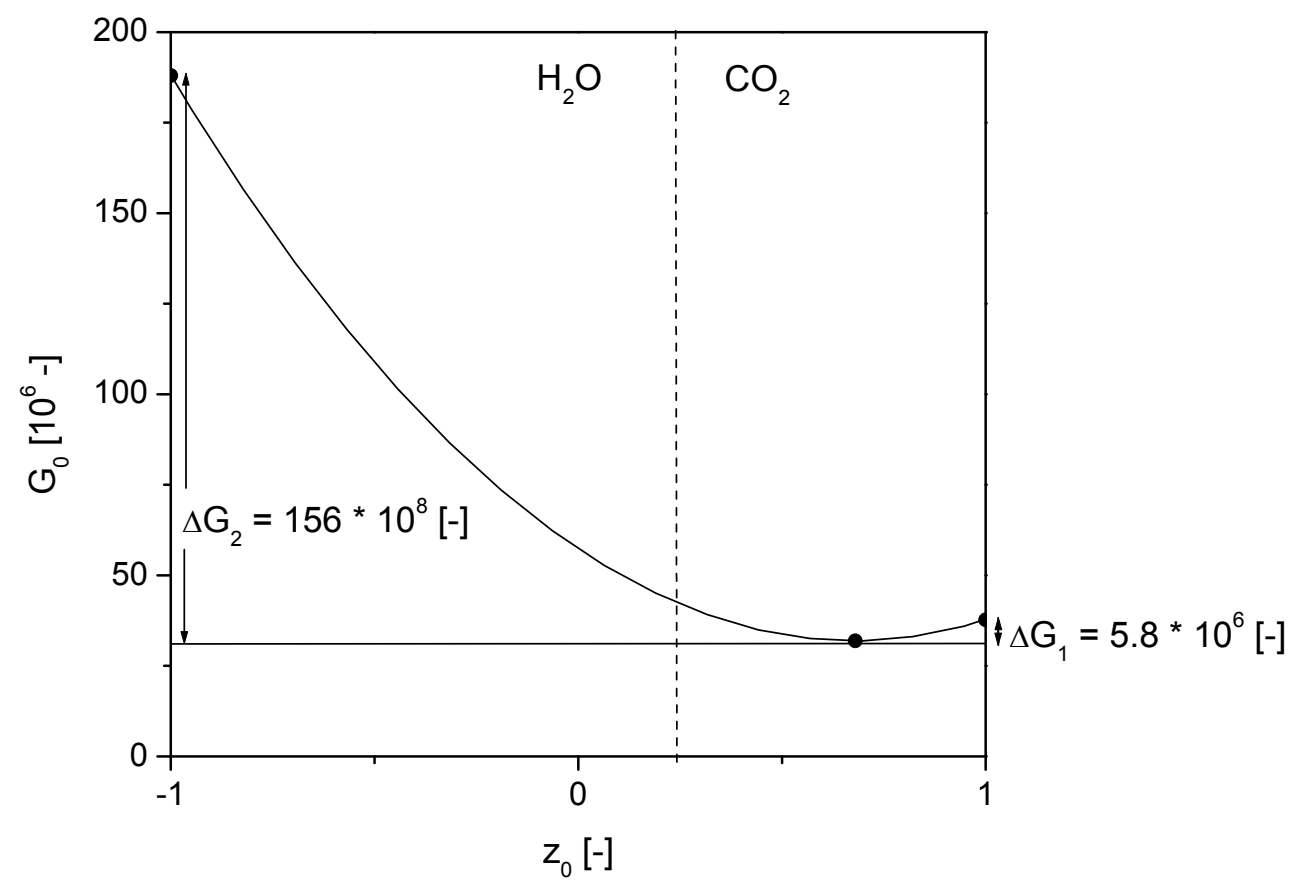

Figure 6 Gibbs energy profile of a $100 \mathrm{~nm}$ PMMA particle in a $\mathrm{CO}_{2}-\mathrm{H}_{2} \mathrm{O}$ interfacial region at 100 bar and $35^{\circ} \mathrm{C}$, without surfactant.

For the other systems, i.e. a PS particle in a $\mathrm{CO}_{2}-\mathrm{H}_{2} \mathrm{O}$ system at 100 bar and $35^{\circ} \mathrm{C}$ without surfactant, a PMMA particle in a $\mathrm{CO}_{2}-\mathrm{H}_{2} \mathrm{O}$ system at 100 bar and $35^{\circ} \mathrm{C}$ with surfactant, a PS particle in a $\mathrm{CO}_{2}-\mathrm{H}_{2} \mathrm{O}$ system at 100 bar and $35{ }^{\circ} \mathrm{C}$ with surfactant, similar graphs are obtained.

According to the theory of Torza and Mason (1970) as well as the theory of Colver et al. (2006), when PS or PMMA latex, stabilized with SDS as surface active agent, are submerged into a $(\mathrm{sc}) \mathrm{CO}_{2}$ environment, the polymer particles will be completely wetted by the $(\mathrm{sc}) \mathrm{CO}_{2}$. Moreover, the polymer particles are trapped in the $(\mathrm{sc}) \mathrm{CO}_{2}$ phase or in other words the particles irreversibly move from the $\mathrm{H}_{2} \mathrm{O}$ phase into the $(\mathrm{sc}) \mathrm{CO}_{2}$ phase!

This conclusion has not been confirmed by our experimental observations. In a mixture of a PS latex, stabilized with SDS, and $\mathrm{CO}_{2}$ at 100 bar and $35^{\circ} \mathrm{C}$, the polymer particles were "homogeneously" distributed throughout the mixture. No phase separation between the $\mathrm{H}_{2} \mathrm{O}$ 
phase and the $\mathrm{CO}_{2}$ phase containing the polymer particles occurred, i.e. flotation of the polymer particles in the lighter $\mathrm{CO}_{2}$ phase was not observed.

The calculated results have been obtained with interfacial tension data from literature, see Tables 1-4. The polymer films used in literature were all annealed at temperatures above their glass transition temperature to exclude any effect of the synthesis method or by impurities on the result of the measurement. Van de Ven (1975) emphasized the influence of history effects describing colloidal interactions in a PS latex. Huvard et al. (1980) also reported about the influence of annealing poly acrylonitrile (PAN) on $\mathrm{CO}_{2}$ sorption. Huvard et al.(1980) observed that the sorption capacity of glassy PAN microspheres decreased by $\sim 30 \%$ after annealing the microspheres. The author refers to Koros and Paul (1978) and to Chan and Paul. (1978) who observed similar effects in $\mathrm{CO}_{2}$ sorption in poly(ethylene terephtalate) and in polycarbonate, respectively. It is believed that including history effects also has a profound effect on interfacial characteristics.

The interfacial tension between $\mathrm{H}_{2} \mathrm{O}$ containing the surfactant SDS and $\mathrm{CO}_{2}$ decreases with a factor 8 in comparison to the interfacial tension between surfactant free $\mathrm{H}_{2} \mathrm{O}$ and $\mathrm{CO}_{2}$, due to the orientation of the surfactant at the interface. The interactions between the polar part of the surfactant and $\mathrm{H}_{2} \mathrm{O}$ on one hand and between the non polar part and $\mathrm{CO}_{2}$ on the other hand are much stronger than the interactions between $\mathrm{H}_{2} \mathrm{O}$ and $\mathrm{CO}_{2}$, as explained earlier. In latex systems, the tail group of the surfactant is oriented inside the polymer particles. When all surfactant is located on the polymer particles, interaction between $\mathrm{H}_{2} \mathrm{O}$ and $\mathrm{CO}_{2}$ weakens in comparison to a surfactant orientation over the $\mathrm{H}_{2} \mathrm{O} / \mathrm{CO}_{2}$ interface. Note that the polymer particles are surrounded by an electrical double layer of ions, changing the interaction with $\mathrm{CO}_{2}$

In either case of positioning of the polymer particles, i.e. at the $\mathrm{H}_{2} \mathrm{O} / \mathrm{CO}_{2}$ interface or completely in the $\mathrm{CO}_{2}$ phase, it should be realized that the particles are so small that the maximum fractional interface coverage of $74 \%$ is reached. 


\section{Mass transfer resistance}

In the solid-to-fluid (SF) mass transport approach, i.e. the shuttle effect, monomer diffuses directly from the polymer particles to the $(\mathrm{sc}) \mathrm{CO}_{2}$ phase. The residence time, $\mathrm{t}_{\text {contact, } \mathrm{P}}$ of one polymer particle at the $\mathrm{H}_{2} \mathrm{O} /(\mathrm{sc}) \mathrm{CO}_{2}$ interface, calculated with Equations 3 and 4 for $100 \mathrm{~nm}$ particles, is $3.8 * 10^{-4} \mathrm{~s}$. Within this time monomer is transferred from the polymer to the (sc) $\mathrm{CO}_{2}$ phase. The overall resistance against mass transfer at the position where the polymer contacts the $\mathrm{H}_{2} \mathrm{O} / \mathrm{CO}_{2}$ interface is expressed in Equation 17.

$$
\left(\frac{1}{\mathrm{k} * \mathrm{a}}\right)_{\text {overall }}=\left(\frac{1}{\mathrm{k} * \mathrm{a}}\right)_{\text {polymer phase }}+\left(\frac{1}{\mathrm{k} *_{\mathrm{a}} * \mathrm{~K}_{\text {mon }}^{\text {polymer } / \mathrm{CO}_{2}}}\right)_{\mathrm{CO}_{2} \text { phase }}
$$

The specific area available for mass transport, a $\left[\mathrm{m}^{2} / \mathrm{m}^{3}\right.$ polymer], for spherical particles applies. The partition coefficient $\mathrm{K}_{\text {mon }}^{\text {polymer } / \mathrm{CO}_{2}}$ is defined as the ratio of monomer concentration in the $\mathrm{CO}_{2}$ phase and the monomer concentration in the polymer phase, see Equation 18.

$$
\mathrm{K}_{\mathrm{m}}=\frac{\mathrm{C}_{\mathrm{m}}^{\mathrm{CO}_{2}}}{\mathrm{C}_{\mathrm{m}}^{\text {pol }}}\left[\frac{\mathrm{kg} \text { polymer }}{\mathrm{kg} \mathrm{CO}_{2}}\right]
$$

When it is assumed that the polymer particle contacts the $\mathrm{H}_{2} \mathrm{O} / \mathrm{CO}_{2}$ at one point, see Figure 7 , mass transfer from the polymer particle through the interfacial region to the $\mathrm{CO}_{2}$ phase is also possible.

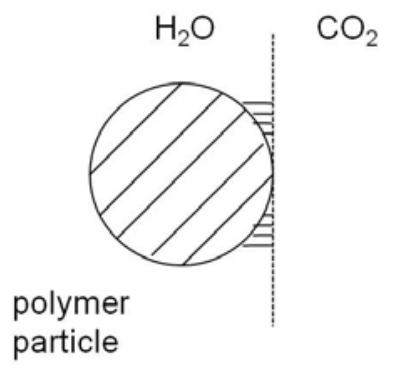

Figure 7 Mass transfer from the polymer particle through the interfacial region to the (sc) $\mathrm{CO}_{2}$ phase.

The overall resistance against mass transfer through the interfacial region is expressed in Equation 19, see also Figure 8. 


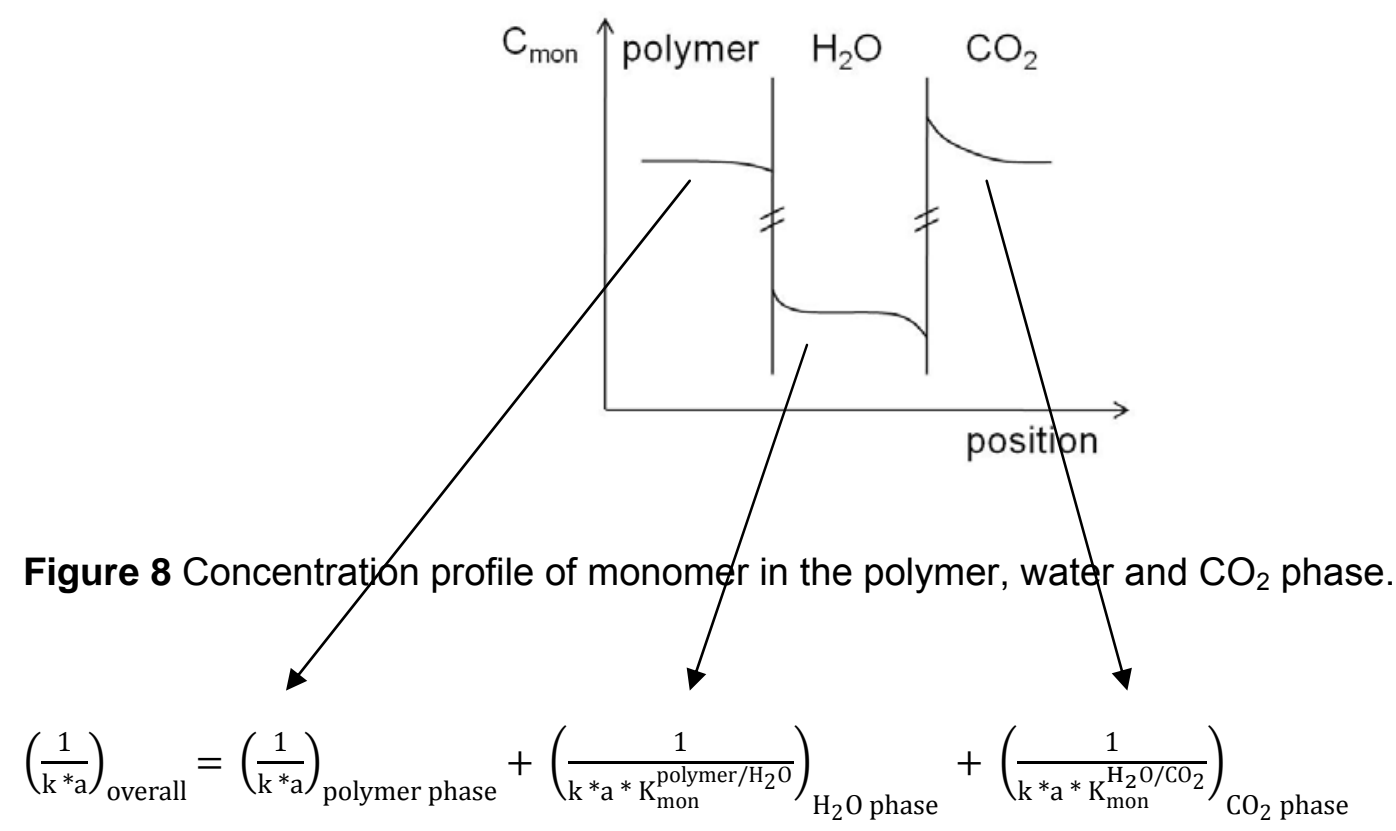

The mass transfer coefficient of monomer in the $\mathrm{H}_{2} \mathrm{O}$ phase is defined by the film theory, see Equation 1, averaged over the distance between the particle and the $\mathrm{H}_{2} \mathrm{O} / \mathrm{CO}_{2}$ interface.

\section{Example}

It is assumed that residual monomer from PS latex and from PMMA latex is extracted by (sc) $\mathrm{CO}_{2}$ in a countercurrent column. Latex has been chosen as the continuous phase, (sc) $\mathrm{CO}_{2}$ is dispersed as $1 \mathrm{~mm}$ bubbles through the latex. Table 5 gives the parameters used to calculate the mass transfer resistance in each phase. The mass transfer coefficient of monomer in the polymer phase has been calculated according to Equation 5 (Fo $<0.1$ ), for a diffusion coefficient of monomer in $\mathrm{CO}_{2}$-swollen polymer of $10^{-12} \frac{\mathrm{m}^{2}}{\mathrm{~s}}$. The concentration leveling in a $1 \mathrm{~mm} \mathrm{CO}_{2}$ bubble, i.e. when $\mathrm{Fo}=0.1$, requires $7 \mathrm{~s}$; the mass transfer coefficient of monomer in the $\mathrm{CO}_{2}$ bubble has then been calculated with Equation 5 for $\mathrm{CO}_{2}$ instead of polymer. The mass transfer coefficient of monomer in water has been calculated for distances from the $\mathrm{H}_{2} \mathrm{O} / \mathrm{CO}_{2}$ interface to the surface of the polymer particle of 1 to $10 \mathrm{~nm}$. 
Table 5 Parameters used in the prediction of the mass transfer resistance in the polymer particles, $-\mathrm{H}_{2} \mathrm{O} / \mathrm{CO}_{2}$ interfacial region and in the $\mathrm{CO}_{2}$ bubble at 100 bar and $35{ }^{\circ} \mathrm{C}$. (Kemmere et al., 2005, González et al., 2007)

\begin{tabular}{l|c|c|c|c|c|c}
\hline polymer & $\mathrm{k}_{\mathrm{m}}^{\mathrm{p}}\left[\frac{\mathrm{m}}{\mathrm{s}}\right]$ & $\mathrm{D}_{\mathrm{m}}^{\mathrm{CO}_{2}}\left[\frac{\mathrm{m}^{2}}{\mathrm{~s}}\right]$ & $\mathrm{k}_{\mathrm{m}}^{\mathrm{CO}_{2}}\left[\frac{\mathrm{m}}{\mathrm{s}}\right]$ & $\mathrm{k}_{\mathrm{m}}^{\mathrm{H}_{2} \mathrm{O}}\left[\frac{\mathrm{m}}{\mathrm{s}}\right]$ & $\mathrm{K}_{\mathrm{m}}^{\mathrm{P} / \mathrm{H}_{2} \mathrm{O}}\left[\frac{\mathrm{kg} \mathrm{H}_{2} \mathrm{O}}{\mathrm{kg} \mathrm{P}}\right]$ & $\mathrm{K}_{\mathrm{m}}^{\mathrm{H}_{2} \mathrm{O} / \mathrm{CO}_{2}\left[\frac{\mathrm{kg} \mathrm{CO}_{2}}{\mathrm{~kg} \mathrm{H}}\right]}$ \\
\hline PS & $7^{*} 10^{-5}$ & $1.4^{*} 10^{-8}$ & $5^{*} 10^{-5}$ & $4^{*} 10^{-1}$ & $3^{*} 10^{-3}$ & 20 \\
\hline PMMA & $7^{*} 10^{-5}$ & $6.8^{*} 10^{-8}$ & $2.4^{*} 10^{-4}$ & $4^{*} 10^{-1}$ & $1.5^{*} 10^{-2}$ & 15 \\
\hline
\end{tabular}

The partition coefficients of monomer between the polymer particles swollen with $\mathrm{CO}_{2}$ and the $(\mathrm{sc}) \mathrm{CO}_{2}$ phase have been experimentally determined, see Chapter 3 ,

$\mathrm{K}_{\mathrm{sty}}^{\mathrm{PS} / \mathrm{CO}_{2}}=2\left[\frac{\mathrm{kg} \mathrm{PS}}{\mathrm{kg} \mathrm{CO}_{2}}\right]$ and $\mathrm{K}_{\mathrm{MMA}}^{\mathrm{PMMA} / \mathrm{CO}_{2}}=0.3\left[\frac{\mathrm{kg} \mathrm{PMMA}}{\mathrm{kg} \mathrm{CO}_{2}}\right]$.

Table 6 collects the resulting mass transfer resistances in the polymer as well as in the $\mathrm{CO}_{2}$ phase respectively, see Equation 17. Calculations have been performed including the specific surface area with relation to the surface area of the $\mathrm{CO}_{2}$ bubble.

Table 6 Time constants for the mass transfer resistance in the polymer and $\mathrm{CO}_{2}$ phase at the contact point of polymer particle and $\mathrm{H}_{2} \mathrm{O} / \mathrm{CO}_{2}$ interface

\begin{tabular}{l|c|c}
\hline polymer & $\left(\frac{1}{\mathrm{k} * \mathrm{a}}\right)_{\text {polymer phase }}[\mathrm{s}]$ & $\left(\frac{1}{\mathrm{k} * \mathrm{a} * \mathrm{~K}_{\text {mon }}^{\mathrm{polymer} / \mathrm{CO}_{2}}}\right)_{\mathrm{CO}_{2} \text { phase }}[\mathrm{s}]$ \\
\hline \hline PS & 2.3 & 1.67 \\
\hline PMMA & 2.3 & 0.02 \\
\hline
\end{tabular}

Table 6 shows the mass transfer resistance in extraction of residual monomer from PS latex as well as from PMMA latex with $(\mathrm{sc}) \mathrm{CO}_{2}$ is for the major part inside the polymer particles.

Table 7 gives the calculated resistance against mass transfer inside the polymer particle, through the $\mathrm{H}_{2} \mathrm{O} / \mathrm{CO}_{2}$ interfacial region as well as in the $\mathrm{CO}_{2}$ bubble not attached to the polymer particle, see Equation 19. 
Table 7 Time constants for the mass transfer resistance in the polymer, $\mathrm{H}_{2} \mathrm{O}$ and $\mathrm{CO}_{2}$ phase

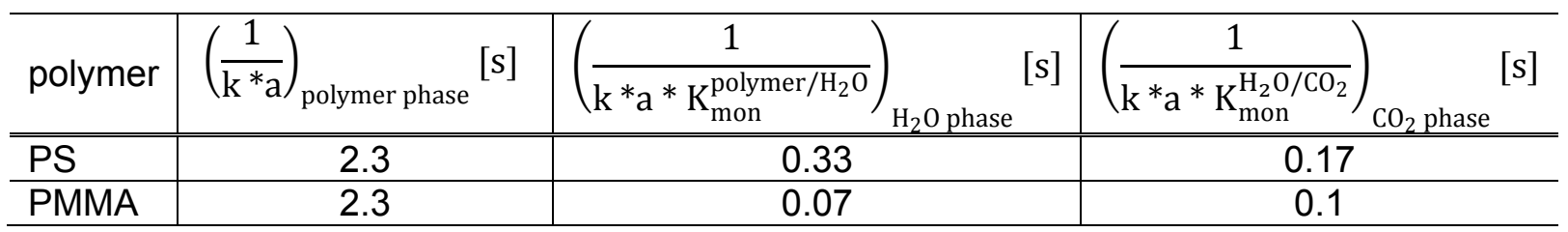

The mass transfer resistance in extraction of residual monomer from PS latex as well as from PMMA latex with (sc) $\mathrm{CO}_{2}$ is for the major part inside the polymer particles. Meier et al. (1997) reported similar observations studying steam stripping of PS latex. These authors demonstrated that diffusion resistance inside the latex particles can only be neglected when the residence time of the particles is significantly larger than the diffusion time of the transferred compounds inside the polymer particles. In the present work the residence time of a polymer particle at the $\mathrm{H}_{2} \mathrm{O} / \mathrm{CO}_{2}$ interface, see Equation 3 , is $4 * 10^{-4} \mathrm{~s}$. The time constant for monomer transport in the polymer particles to the $\mathrm{CO}_{2}$ phase is $2.3 \mathrm{~s}$, larger than that in water for PS and considerably larger than that for water in PMMA. The resistance against mass transfer in $\mathrm{CO}_{2}$ is negligible. Therefore only the resistance inside the polymer particles has to be taken into account for the estimation of mass transfer rates of monomer from the particles to the $\mathrm{CO}_{2}$ phase.

\section{Concluding remarks}

In the extraction with $(\mathrm{sc}) \mathrm{CO}_{2}$ to reduce residual monomer in a polymer latex, the shuttle mechanism has been found to govern mass transport. Due to Brownian motion the polymer particles move to and from the $\mathrm{H}_{2} \mathrm{O} / \mathrm{CO}_{2}$ interface, improving mass transfer. According to the theory of Torza and Mason (1970) and Colver et al. (2006) the $\mathrm{CO}_{2}$ completely wets the polymer particles in latex systems stabilized with ionic surfactants. Experimental observation of the behavior of latex submerged in a $(\mathrm{sc}) \mathrm{CO}_{2}$ environment did not confirm the theoretical predictions. History effects have been removed obtaining the specific literature data used in the theoretical considerations. The existence of an electrical double layer surrounding the polymer particles may also affect the calculated results. The main resistance against mass transfer has been demonstrated to be located inside the polymer particles. 


\section{References}

H. E. A. van den Akker, R. F. Mudde, E. Stammers, "Fysische transportverschijnselen: 200 vraagstukken", 1997, $2^{\text {nd }}$ ed., Delft University Press, The Netherlands

E. Alper, B. Wichtendahl, W. D. Deckwer, "Gas absorption mechanism in catalytic slurry reactors", Chem. Eng. Sci., 1980, 35, 217-222

A. A. C. M. Beenackers, W. P. M. van Swaaij, "Mass transfer in gas-liquid slurry reactors", Chem. Eng. Sci., 1993, 48, 18, 3109-3139

R. B. Bird, W. E. Stewart, E. N. Lightfoot, "Transport phenomena",2002, $2^{\text {nd }}$ edition, J. Wiley and sons Inc., New York

D. W. F. Brilman, W. P. M. van Swaaij, G. F. Versteeg, "A one-dimensional instationary heterogeneous mass transfer model for gas absorption in multiphase systems", Chem. Eng. Process., 1998, 37, 471-488

A. H. Chan, D. R. Paul, "Effect of sub- $\mathrm{T}_{\mathrm{g}}$ annealing on $\mathrm{CO}_{2}$ sorption in polycarbonate", $A C S$ Preprints, 1978, 39, 230

D. K. Chattoraj, "Thermodynamics of adsorption at interfaces and the Gibbs surface excess", PINSA, 2001, 67A, 6, 663-685

Y-C. Chen, V. Dimonie, M. S. El-Aasser, " Interfacial phenomena controlling particle morphology of composite latexes", J. Appl. Polym. Sci., 1991, 42, 1049-1063

Y-C. Chen, V. Dimonie, M. S. El-Aasser, "Effect of interfacial phenomena on the development of particle morphology in a polymer latex system", Macromolec., 1991, 24, 3779-3787

C. H. Chon, K. D. Kihm, S. P. Lee, S. U. S. Choi, "Empirical correlation finding the role of temperature and particle size for nanofluid $\left(\mathrm{Al}_{2} \mathrm{O}_{3}\right)$ thermal conductivity enhancement", Appl. Phys. Lett. , 2005, 87, 153107

P. J. Colver, T. Chen, S. A. F. Bon, "Supracolloidal structures through liquid-liquid interface driven assembly and polymerization", Macromol. Symp., 2006, 245-246, 34-41

V. V. Dhanuka, J. L. Dickson, W. Ryoo, K. P. Johnston, "High internal phase $\mathrm{CO}_{2}$-in-water emulsions stabilized with a branched nonionic hydrocarbon surfactant", J. Colloid Interface Sci., 2006, 298, 406-418

E. Dumont, H. Delmas, "Mass transfer enhancement of gas absorption in oil-in-water systems: a review", Chem. Eng. Process., 2003, 42, 419-438

P. Finkle, H. D. Draper, J. H. Hildebrand, J. Amer. Chem. Soc., 1923, 45, 12, 2780-2788

L. M. González, O. Suárez-Iglesias, J. L. Bueno, C. Pizarro, I. Medina, "Limiting binary diffusivity of aniline, styrene, and mesitylene in supercritical carbon dioxide", J. Chem. Eng. Data, 2007, 52, 1286-1290

K. L. Harrison, K. P. Johnston, I. C. Sanchez, "Effects of surfactants on the interfacial tension between carbon dioxide and polyethylene glycol", Langmuir, 1996, 12, 2637-2544

P. C. Hiemenz, R. Rajagopalan, "Principles of colloid and surface chemistry", 3th ed., 1997, Marcel Dekker, Inc., New York 
G. S. Huvard, V. T. Stannett, W. J. Koros, H. P. Hopfenberg, "The pressure dependence of $\mathrm{CO}_{2}$ sorption and permeation in poly(acrylonitrile)", J. Membrane Sci., 1980, 6, 185-201

P. T. Jaeger, J. v. Schnitzler, R. Eggers, "Interfacial tension of fluid systems considering the nonstationary case with respect to mass transfer", Chem. Eng. Technol., 1996, 19, 197-202

S. P. Jang, S. U. S. Choi, "Role of Brownian motion in the enhanced thermal conductivity of nanofluids", Appl. Phys. Lett., 2004, 84, 21, 4316-4318

C. Joly-Vuillemin, C. Bellefon, "Solids effects on gas-liquid mass transfer in three-phase slurry catalytic hydrogenation of adiponitrile over raney nickel", Chem. Eng. Sci., 1999, 51, $10,2149-2158$

J-Y. Jung, J. Y. Yoo, "Thermal conductivity enhancement of nanofluids in conjunction with electrical double layer (EDL)", Int. J. Heat Mass Transfer, 2009, 52, 525-528

M. F. Kemmere, M. Cleven, M. A. van Schilt, J. T. F. Keurentjes, "Process design for the removal of residual monomer from latex products using supercritical carbon dioxide", Chem. Eng. Sci., 2002, 57, 3929-3937

M. F. Kemmere, M. van Schilt, M. Jacobs, J. T. F. Keurentjes, "Reduction of residual monomer in latex products using high pressure carbon dioxide", in "Supercritical carbon dioxide in polymer reaction engineering”, M. F. Kemmere, T. Meyer, Eds., 2005, Wiley-VCH, Germany

W. J. Koros, D. R. Paul, " $\mathrm{CO}_{2}$ sorption in poly(ethylene terephtalat) above and below glass transition", J. Polym. Sci., Polym. Phys. Ed., 1978, 16, 1947

D. W. van Krevelen in "Properties of Polymers"; 3rd Ed., Amsterdam: Elsevier, 1997, Chapter 8

B. Kvamme, T. Kuznetsova, A. Hebach, A. Oberhof, E. Lunde, "Measurements and modeling of interfacial tension for water + carbon dioxide systems at elevated pressures", Comp. Mat. Sci., 2007, 38, 506-513

D. Meier, H.-J. Warnecke, J. Prüss, "Modelling of mass transfer of volatile organic compounds in polymer dispersions", Chem. Eng. J. , 1997, 67, 45-53

M. L. O'Neill, Q. Cao, M. Fang, K. P. Johnston, S. P. Wilkinson, C. D. Smith, J. L. Kerschner, S. H. Jureller, "Solubility of homopolymers and copolymers in carbon dioxide", Ind. Eng. Chem. Res., 1998, 37, 3067-3079

K. Otake, M. Kobayashi, Y. Ozaki, S. Yoda, Y. Takebayashi, T. Sugeta, N. Nakazawa, H. Sakai, M. Abe, "Surface activity of myristic acid in the poly(methyl methacrylate)/supercritical carbon dioxide system”, Langmuir, 2004, 20, 6182-6186

D. K. Owens, R. C. Wendt, "Estimation of the surface free energy of polymers", J. Appl. Polym. Sci., 1969, 13, 1741-1747

S. U. Pickering, “Emulsions”, J. Chem. Soc. Transactions, 1907, 91, 2001-2021

S. R. P. da Rocha, K. P .Johnston, R. E. Wetsacott, P. J. Rossky, "Molecular structure of the water-supercritical $\mathrm{CO}_{2}$ interface", J. Phys. Chem. B, 2001, 105, 12092-12104

M. J. Rosen in "Surfactants and interfacial phenomena"; 3rd Ed., New York: John Wiley \& sons, Inc., 2004, Chapter 5 
D. C. Sundberg, A. P. Cacassa, J. Pantazopoulos, M. R. Muscato, "Morphology development of polymeric microparticles in aqueous dispersions. I. Thermodynamic considerations", J. Appl. Polym. Sci., 1990, 41, 1425-1442

E. Sundberg, D. C. Sundberg, "Morphology development for three-component emulsion polymers: Theory and experiments", J. Appl. Polym. Sci., 1993, 47, 1277-1294

F. Tewes, F. Boury, "Thermodynamic and dynamic interfacial properties of binary carbon dioxide-water systems", J. Phys. Chem. B , 2004, 108, 2405-2412

S. Torza, S. G. Mason, "Three-phase interactions in shear and electrical fields", J. Colloid Interface Sci., 1970, 33, 1, 67-83

T. G. M. van de Ven, PhD thesis, 1975, McGill University, Montreal, Canada

H. Vinke, P. J. Hamersma, J. M. H. Fortuin, "Enhancement of the gas-absorption rate in agitated slurry reactors by gas-absorbing particles adhering to gas bubbles", Chem. Eng. Sci., 1993, 48, 12, 2197-2210

J. A. Waters, "Predicting the surface morphology of composite latex particles", Colloids and Surfaces A: Physicochem. Eng. Aspects, 1994, 83, 167-174

S. E. Webber, P. Munk, K. P. Johnston, K. Otake, "Swelling of polystyrene latex particles in water by high-pressure carbon dioxide", Langmuir, 1997, 13, 20, 3047-3051

J. Welty, C. E. Wicks, R. E. Wilson, "Fundamentals of momentum, heat, and mass transfer", 2001, $4^{\text {th }}$ ed., Wiley, Chichester

S. X. Zhang, W. H. Ray, "Modelling and experimental studies of aqueous suspension polymerization processes. 3. Mass transfer and monomer solubility effects", Ind. Eng. Chem. Res., 1997, 36, 1310-1321 



\title{
Chapter 5
}

\section{Process design for residual monomer reduction in latex with supercritical carbon dioxide}

\begin{abstract}
Processes other than steam stripping or chemical conversion to reduce residual monomer in latex products are being intensively studied. One of the alternative processes is the extraction of residual monomer with high pressure carbon dioxide $\left(\mathrm{CO}_{2}\right)$. In the present work extraction of residual monomer from a latex product with supercritical carbon dioxide $\left((\mathrm{sc}) \mathrm{CO}_{2}\right)$ in a column has been studied. Operating conditions have been chosen at $35^{\circ} \mathrm{C}$ and 100 bar. For reducing the residual styrene level in a polystyrene latex from $10^{4}$ parts per million (ppm) to $1 \mathrm{ppm}$, a countercurrent mechanically agitated extractor with latex as continuous and $(\mathrm{sc}) \mathrm{CO}_{2}$ as the dispersed phase is suggested. Monomer partitioning was demonstrated to be a key issue for equipment design. Monomer transport was found to be governed by the shuttle effect, based on Brownian motion of the latex particles to and from the $\mathrm{H}_{2} \mathrm{O} / \mathrm{CO}_{2}$ interface. The drift flux approach of Wallis was followed to determine the column flooding conditions. The influence of the dispersed phase hold up and the bubble size on the extraction efficiency has been analyzed. Column volumes of $4.75 \mathrm{~m}^{3}$ are obtained for a throughput of $6000 \mathrm{~kg}$ latex/hr.
\end{abstract}

An economic analysis indicates that monomer extraction with $(\mathrm{sc}) \mathrm{CO}_{2}$ is a feasible process. Moreover, the performance compared to steam stripping can be improved, since lower final residual monomer levels can be attained. 


\section{Introduction}

Emulsion polymerization is widely used in industry for the production of paints, coatings, adhesives and rubbers (Gilbert, 1995). The resulting latex is a dispersion of submicron ( 100 $\mathrm{nm}$ ) polymer particles in water. The free radical polymerization does not proceed to completion due to e. g. diffusion limitations of the monomer in the polymer particles. As a consequence, the polymer particles contain a significant amount of residual monomer, generally in the order of magnitude of a thousand parts per million (ppm). Legislation on the residual monomer level in polymer products is becoming increasingly strict. Reducing the residual monomer level is therefore a major incentive for the polymer producing industry. In practice, techniques such as steam stripping or a post polymerization temperature increase to reduce the residual monomer level are both energy intensive, time consuming and unable to meet future requirements (Englund, 1981). A novel method to reduce residual monomer in the latex particles based on high pressure or supercritical carbon dioxide $\left((\mathrm{sc}) \mathrm{CO}_{2}\right)$ extraction is being developed. Polymer particles swell with supercritical or liquid $\mathrm{CO}_{2}$. The fugacity of the free monomer in the particles tremendously increases with the volume fraction of low molecular weight species in the polymer particles on addition of carbon dioxide. Moreover, high pressure $\mathrm{CO}_{2}$ is an excellent extraction medium for various monomers as monomers have a relatively high solubility in $\mathrm{CO}_{2}$, while (very) little water and practically no polymer dissolves in $\mathrm{CO}_{2}$. Solubility and diffusivity of the monomer in ( $\left.\mathrm{sc}\right) \mathrm{CO}_{2}$ can easily be tuned by (small) changes in pressure and temperature. Due to the plasticizing effect the diffusion coefficient $\left(D_{\mathrm{m}}^{\mathrm{P}}\right)$ of the monomer in the polymer particles increases from $\leq 10^{-15} \frac{\mathrm{m}^{2}}{\mathrm{~s}}$ to $10^{-12} \frac{\mathrm{m}^{2}}{\mathrm{~s}}$ or even higher (Alsoy and Duda, 1998).

High pressure or supercritical $\mathrm{CO}_{2}$ behaves partly gas-like, i.e. high diffusivity and low viscosity, and partly liquid-like, i.e. high density. As the density of $\mathrm{scCO}_{2}$ is similar to liquids, the monomer reduction with $\mathrm{scCO}_{2}$ can be described as liquid-liquid extraction. Within liquidliquid extraction the countercurrent arrangement is the best compromise between the objectives of a high extract concentration and a high extraction efficiency (De Haan, 2007). De Haan (2007) gives a comprehensive overview of industrial liquid-liquid extractors and provides some guidance for selecting an appropriate extraction column. Based on this guidance two types of extractors are discussed here: unagitated columns and mechanically 
agitated columns. Unagitated columns are very simple and cheap, but suffer from a low efficiency. Spray towers are the most simple unagitated columns but due to poor phase contacting and severe backmixing in the continuous phase the equivalent of more than one or two theoretical stages or transfer units is hardly achieved (De Haan, 2007, Perry, 1999). In packed columns phase contacting is improved and backmixing is reduced. To avoid coalescence of the dispersed phase, it is required that the packing material is wetted by the continuous phase. Applying a sinusoidal pulsation to the contents of the column, sieve-plate or packed extraction columns improve efficiency (Scholtens, 2001). Maximizing the dispersion of one phase in the other (i.e. minimizing "droplet" size) and minimizing backmixing is also achieved by equipping the extractor with mechanically moving internals. The Scheibel column, rotating disk contactor, asymmetric rotating disk contactor, OldshueRushton multiple mixer column and the Kuhni column employ rotary agitation. The Karr column reciprocates the plates, consuming less energy but agitating evenly well in comparison to rotating devices.

For simplicity, in the present work $(\mathrm{sc}) \mathrm{CO}_{2}$ extraction of residual monomer from a polystyrene latex in an empty, non agitated column has been designed for latex as the continuous and (sc) $\mathrm{CO}_{2}$ as the dispersed phase. It is assumed that there is intensive phase contact and that backmixing in the column is low, see the section 'Monomer transport'. To keep in mind that the $(\mathrm{sc}) \mathrm{CO}_{2}$ phase is dispersed, the extractor is referred to as a bubble column. After extraction at least one additional separation step is required to separate the (sc) $\mathrm{CO}_{2}$ /monomer mixture, thereby allowing recycling of (sc) $\mathrm{CO}_{2}$.

Figure 1 schematically shows the extraction equipment, excluding the separation process on the extract phase. 


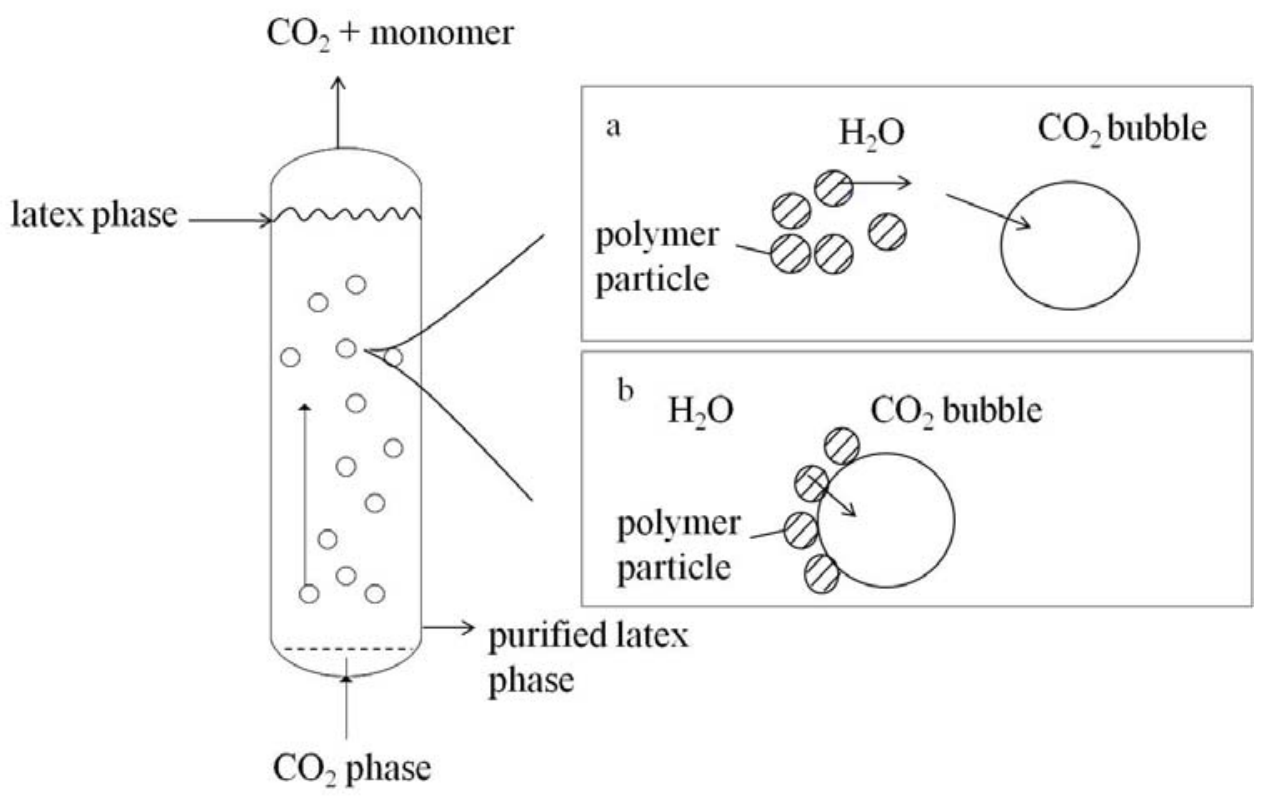

Figure 1 Schematic view of an extraction column for residual monomer reduction in a latex with (sc) $\mathrm{CO}_{2}$.

Calculations have been conducted based on experimentally and theoretically determined parameters, e.g. the partition coefficient, bubble size, dispersed phase hold up, etc., for a reduction of residual monomer from $10^{4} \mathrm{ppm}$ to $100 \mathrm{ppm}$, to $10 \mathrm{ppm}$ and to $1 \mathrm{ppm}$, respectively.

\section{Partitioning}

The key issue for equipment design is partitioning of the monomer between the $\mathrm{CO}_{2}$-swollen latex particles and the $(\mathrm{sc}) \mathrm{CO}_{2}$ phase. Partitioning is expressed in the partition coefficient:

$\mathrm{K}_{\mathrm{m}}=\frac{\mathrm{C}_{\mathrm{m}}^{\mathrm{CO}_{2}}}{\mathrm{C}_{\mathrm{m}}^{\text {pol }}}\left[\frac{\mathrm{kg} \text { polymer }}{\mathrm{kg} \mathrm{CO}_{2}}\right]$

Note that the partition coefficient in general depends on concentrations, i.e. $K_{m}$ is not a constant.

The partition coefficient governs the amount of $(\mathrm{sc}) \mathrm{CO}_{2}$ needed for extraction, as indicated by the mass balance over one stage of a countercurrent extraction column, see Equation 2 (McCabe, 2001), and Figure 2. 


$$
\begin{aligned}
& \phi_{\mathrm{CO}_{2}}=\phi_{\mathrm{p}} * \frac{\mathrm{C}_{\mathrm{m}, \mathrm{n}-1}^{\mathrm{p}}-\mathrm{C}_{\mathrm{m}, \mathrm{n}}^{\mathrm{p}}}{\mathrm{C}_{\mathrm{m}, \mathrm{n}}^{\mathrm{CO}_{2}-\mathrm{C}_{\mathrm{m}, \mathrm{n}+1}^{\mathrm{CO}}}\left[\frac{\mathrm{m}^{3}}{\mathrm{hr}}\right]} \\
& \text { with } \mathrm{C}_{\mathrm{m}, \mathrm{n}}^{\mathrm{CO}_{2}}=\mathrm{K}_{\mathrm{m}} * \mathrm{C}_{\mathrm{m}, \mathrm{n}}^{\mathrm{p}}
\end{aligned}
$$

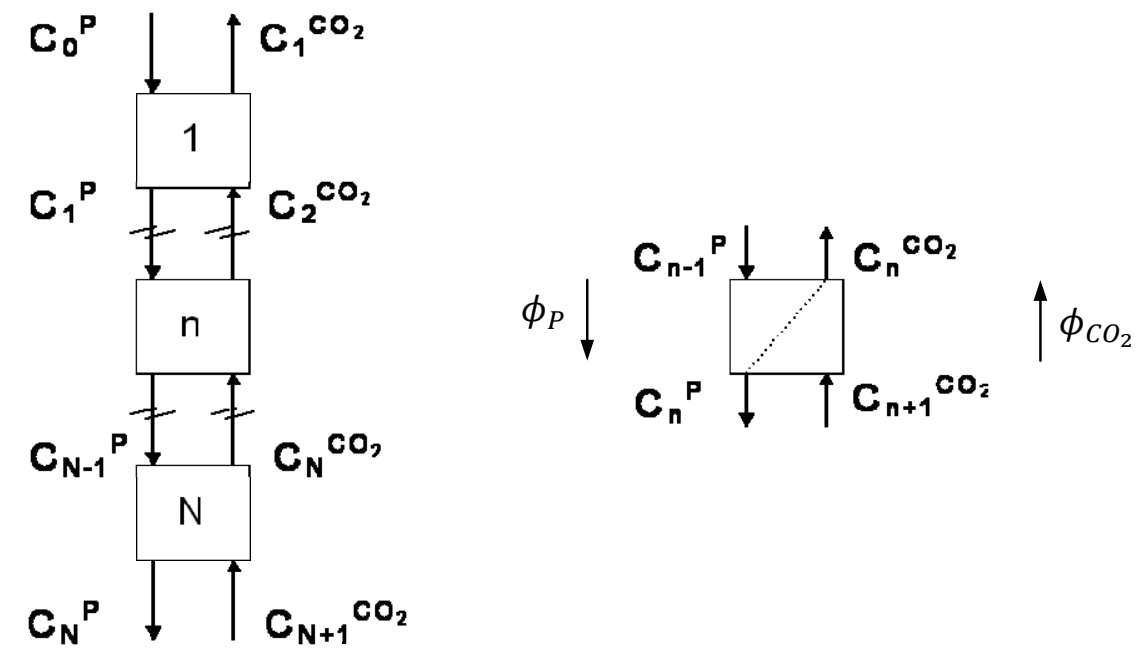

Figure 2 Flowrates and concentrations in a theoretical stage in extraction equipment.

Swelling the polymer particles with $(\mathrm{sc}) \mathrm{CO}_{2}$, decreases the volume fraction of polymer in the polymer phase (i.e. the polymer particles). The polymer volume fraction completely remains in the reduced state during the extraction process in the column as the polymer particles are swollen with ( $\mathrm{sc}) \mathrm{CO}_{2}$. Consequently, the monomer partition coefficient does not change from stage to stage, but can be assumed to be a constant.

\section{Monomer transport}

Two mechanisms for transfer of monomer from latex particles to $(\mathrm{sc}) \mathrm{CO}_{2}$ operate in parallel: the resistance in series approach, i.e. solid-to-liquid-to-fluid (SLF) mass transfer as well as a direct solid-to-fluid (SF) mass transfer model, also referred to as the shuttle effect (Beenackers, 1993, Vinke, 1993).

In the resistance in series approach, the monomer diffuses out of the polymer particles through the $\mathrm{H}_{2} \mathrm{O}$ phase into the $(\mathrm{sc}) \mathrm{CO}_{2}$ phase. The main resistance against mass transfer is located in the $\mathrm{H}_{2} \mathrm{O}$ phase due to low monomer solubility (Zhang, 1997), see Figure 3. 

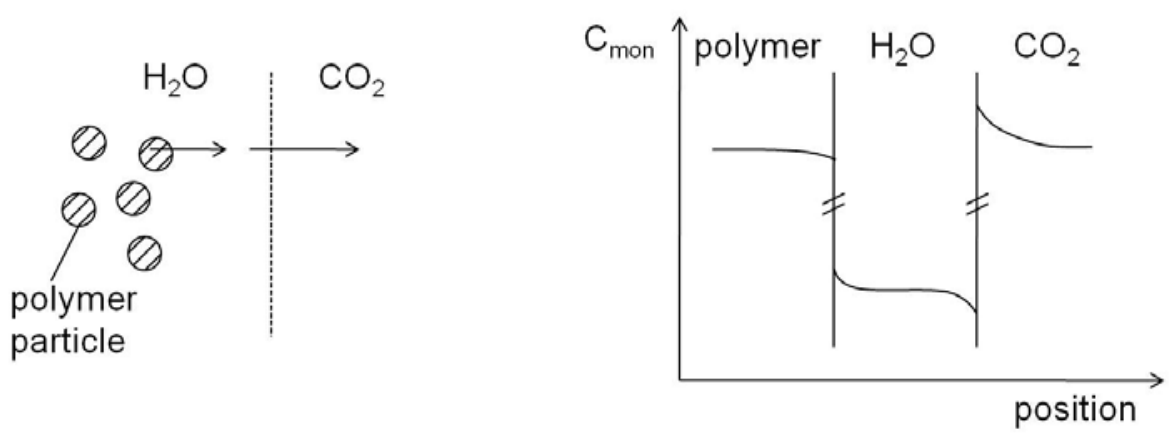

Figure 3 The resistance in series mass transport approach.

Describing the diffusion of monomer in through the three phases, i.e. the polymer particles, the $\mathrm{H}_{2} \mathrm{O}$ phase and the $\mathrm{CO}_{2}$ phase, the film model has been used. The overall molar mass transfer flux of the monomer $\left(\phi_{\mathrm{mon}}\right)$ is expressed in Equation 4.

$$
\begin{gathered}
\phi_{\text {mon }}=\left[\left(\frac{1}{k_{\mathrm{m}}^{\mathrm{P}}}\right)_{\mathrm{P} \text { phase }}+\left(\frac{1}{\left.\mathrm{k}_{\mathrm{m}}^{\mathrm{H}_{2} \mathrm{O}} * \mathrm{~K}_{\mathrm{mon}}^{\text {polymer/ } \mathrm{H}_{2} \mathrm{O}}\right)_{\mathrm{H}_{2} \mathrm{O} \text { phase }}+\left(\frac{1}{\mathrm{k}_{\mathrm{m}}^{\mathrm{CO}_{2}} * \mathrm{~K}_{\mathrm{mon}}^{\mathrm{H}_{2} \mathrm{O} / \mathrm{CO}_{2}}}\right) \mathrm{CO}_{2} \text { phase }}\right]^{-1} * \mathrm{a}_{\mathrm{p}} *\right. \\
*\left(\mathrm{C}_{\mathrm{m}}^{\mathrm{P}}-\frac{\mathrm{C}_{\mathrm{m}}}{\mathrm{K}_{\mathrm{mon}}^{\text {polymer } / \mathrm{H}_{2} \mathrm{O}} * \mathrm{~K}_{\mathrm{mon}}^{\mathrm{H}_{2} \mathrm{O} / \mathrm{CO}_{2}}}\right)
\end{gathered}
$$

with $\mathrm{k}_{\mathrm{m}}^{\mathrm{i}}$ the monomer mass transfer coefficient in phase $\mathrm{i}, \mathrm{K}_{\mathrm{mon}}^{\mathrm{i} / \mathrm{j}}$ the monomer partition coefficient between phase $\mathrm{i}$ and phase $\mathrm{j}, \mathrm{a}_{\mathrm{p}}$ the specific mass transfer area of the polymer particles.

In the SF mass transfer approach, the polymer particles move through the $\mathrm{H}_{2} \mathrm{O}$ phase towards the $\mathrm{H}_{2} \mathrm{O} / \mathrm{CO}_{2}$ interface. The monomer diffuses out of the polymer particles directly into the $(\mathrm{sc}) \mathrm{CO}_{2}$ phase, see Figure 4.

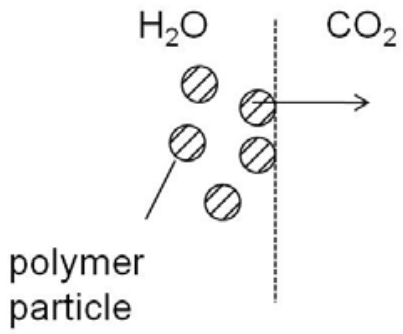

Figure 4 The shuttle mechanism. 
The submicron polymer particles follow Brownian motion and consequently can reside for some time at the (sc) $\mathrm{CO}_{2} / \mathrm{H}_{2} \mathrm{O}$ interface (Brilman, 1998). At the $(\mathrm{sc}) \mathrm{CO}_{2} / \mathrm{H}_{2} \mathrm{O}$ interface the polymer particle is in direct contact with the $(\mathrm{sc}) \mathrm{CO}_{2}$ phase allowing direct diffusional transport of the monomer from the polymer particles to the $(\mathrm{sc}) \mathrm{CO}_{2}$ phase. Alper et al. (1980) used the boundary layer model to describe mass transfer by the shuttle mechanism. However, in case of a system with particles with a limited amount of material to be transferred, stationary models cannot be applied. After a certain contact time the particles near the interface have lost part of the initially present monomer. Dumont et al. (2003) emphasizes that in many situations the contact time between particle and fluid is so short that only unsteady-state models can be used to estimate the mass transfer coefficient in the SF approach.

Concentration leveling of the monomer in the polymer phase is related to time or the Fourier number, see Equation 5 and Figure 5.

Fo $=\frac{D_{\mathrm{m}}^{\mathrm{P}} * \mathrm{t}_{\text {contact, } \mathrm{P}}}{\mathrm{d}_{\text {particle }}^{2}}$

with $t_{\text {contact, }} P$ the contact time of the polymer at the $\mathrm{H}_{2} \mathrm{O} / \mathrm{CO}_{2}$ interface, $d_{\text {particle }}$ the polymer particle diameter.

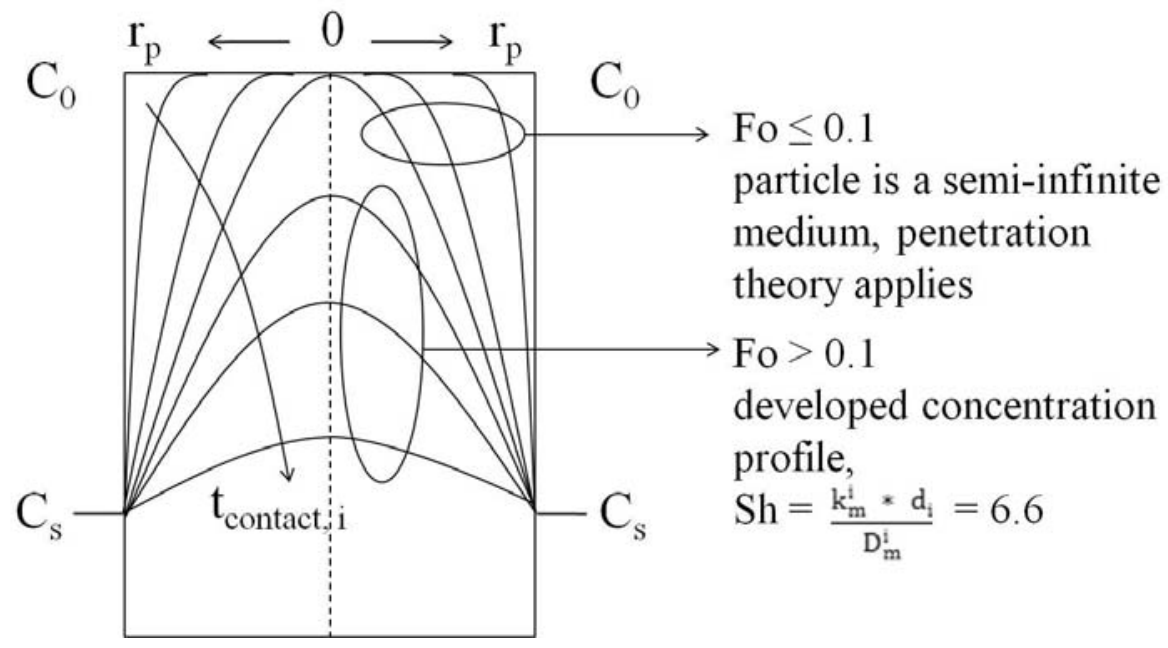

Figure 5 Concentration leveling of the monomer in a polymer particle. $r_{p}$ is the polymer particle radius, $\mathrm{C}_{0}$ the monomer concentration at $\mathrm{t}_{\text {contact }}=0, \mathrm{C}_{\mathrm{s}}$ the monomer concentration at the polymer particle surface. 
Chon et al. (2005) suggest that the residence time of polymer particles at the $\mathrm{H}_{2} \mathrm{O} /(\mathrm{sc}) \mathrm{CO}_{2}$ interface can be regarded in terms of Brownian motion of the polymer particles in the $\mathrm{H}_{2} \mathrm{O}$ phase, see Equation 6. Chon et al. (2005) used $\mathrm{Al}_{2} \mathrm{O}_{3}$ nanoparticles to increase the heat conductivity of water and validated that Brownian motion of the nanoparticles is the key mechanism for thermal conductivity enhancement. Comparable observations are reported by other authors (Jang, 2004).

$\mathrm{t}_{\text {contact, } \mathrm{p}}=\frac{\Delta \mathrm{s}}{\mathrm{v}_{\mathrm{Br}}}$

$\Delta s$ is the distance a polymer particle travels through the $\mathrm{H}_{2} \mathrm{O}$ phase towards the $\mathrm{H}_{2} \mathrm{O} / \mathrm{CO}_{2}$ interface. The length scale of the interfacial region is assumed to be $10 \mu \mathrm{m}$ (Kemmere, 2002); $\Delta s$ is of the same order of magnitude. $\mathrm{v}_{\mathrm{Br}}$ is the velocity of the polymer particles due to Brownian motion, see Equation 7.

$\mathrm{v}_{\mathrm{Br}}=\frac{\mathrm{k}_{\mathrm{b}} * \mathrm{~T}}{3 * \pi * \eta * \mathrm{~d}_{\text {particle }} * \mathrm{l}_{\mathrm{BF}}}$

with $\mathrm{k}_{\mathrm{b}}$ the Boltzman constant, $\eta$ the $\mathrm{H}_{2} \mathrm{O}$ viscosity, $\mathrm{I}_{\mathrm{BF}}$ the mean free path of the particle in water $\left(\mathrm{l}_{\mathrm{H}_{2} \mathrm{O}}=0.17 \mathrm{~nm}(\right.$ Jang, 2004)).

For Fo $\leq 0.1$, mass transport in the polymer particles can be regarded to be in a semi-infinite medium. Then the penetration theory applies for mass transport, see Equation 8 (Welty et al., 2001, Bird et al., 2002 ).

$\mathrm{k}_{\mathrm{m}}^{\mathrm{p}}=2 * \sqrt{\frac{\mathrm{D}_{\mathrm{m}}^{\mathrm{p}}}{\pi * \mathrm{t}_{\text {contact, }} \mathrm{p}}}$

For Fo $>0.1$, i.e. developed concentration profile in the particle, intraparticle mass transport can be described with Equation 9 (van den Akker and Mudde, 1997), see Figure 5.

$\mathrm{Sh}=\frac{\mathrm{k}_{\mathrm{m}}^{\mathrm{P}} * \mathrm{~d}_{\text {particle }}}{\mathrm{D}_{\mathrm{m}}^{\mathrm{P}}}=6.6$

Based on intrinsic properties, i.e. viscosity and surface tension, of the latex and $(\mathrm{sc}) \mathrm{CO}_{2}$, the (sc) $\mathrm{CO}_{2}$ bubbles are assumed to behave as rigid spheres (Wesselingh, 1987, Slater, 1994). The monomer mass transfer coefficient in $(\mathrm{sc}) \mathrm{CO}_{2}$ then depends on the contact time of the polymer particle with the rising $(\mathrm{sc}) \mathrm{CO}_{2}$ bubble $(\sim 1 \mathrm{~mm}$, specified by the sieve plate at the bottom of the column), see Equation 10.

$\mathrm{Fo}=\frac{\mathrm{D}_{\mathrm{m}}^{\mathrm{CO}_{2}} * \mathrm{t}_{\text {contact, }, \mathrm{CO}_{2}}}{\mathrm{~d}_{\mathrm{CO}_{2}}^{2}}$ 
with $\mathrm{D}_{\mathrm{m}}^{\mathrm{CO}_{2}}$ the diffusion coefficient of monomer in the $(\mathrm{sc}) \mathrm{CO}_{2}$ phase and $\mathrm{d}_{\mathrm{CO}_{2}}$ the diameter of a $\mathrm{CO}_{2}$ bubble.

In a certain stage of the column, at the entrance of the $(\mathrm{sc}) \mathrm{CO}_{2}$ bubbles, the bubble needs a time $t_{\text {contact, } \mathrm{CO}_{2}}$ for the average concentration in the bubble and the monomer concentration at the surface to become approximately equal, i.e. Fo $=0.1$, see also Figure 5 . In the neighboring stage, the bubble contacts polymer particles with a higher monomer concentration. Again, the bubble needs a time $\mathrm{t}_{\text {contact, } \mathrm{CO}_{2}}$ to reach $\mathrm{Fo}=0.1$. This cycle repeats itself till the bubble exits the column. Note that the concentration leveling of monomer in the $(\mathrm{sc}) \mathrm{CO}_{2}$ bubble can only develop when the $(\mathrm{sc}) \mathrm{CO}_{2}$ and the latex phase become efficiently mixed after every 7 seconds (follows from Equation 10 for Fo $=0.1 ; 1 \mathrm{~mm} \mathrm{CO}$ bubble). While rising through one transfer unit, $\mathrm{CO}_{2}$ tends to coalesce, decreasing phase contact with the latex phase. After 7 seconds the $\mathrm{CO}_{2}$ bubbles are assumed to redisperse, providing extensive mixing of the $(\mathrm{sc}) \mathrm{CO}_{2}$ and the latex phase at the beginning of each new transfer unit, see Figure 6.

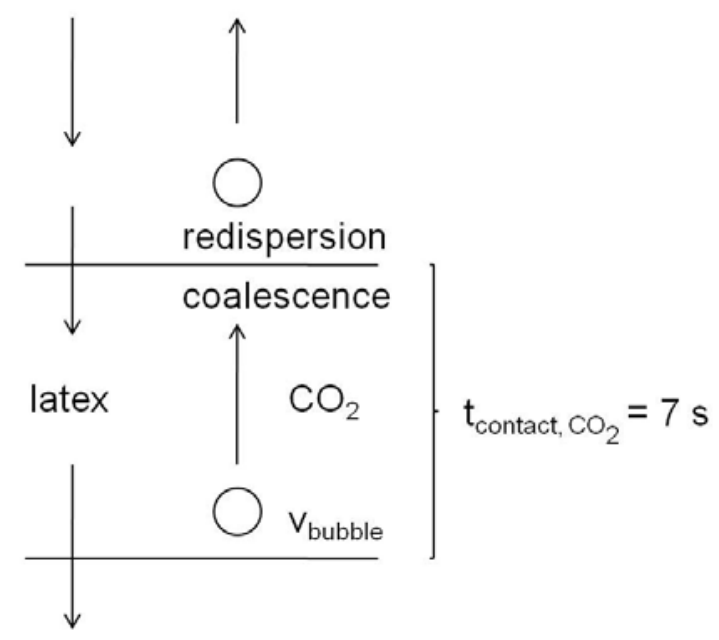

Figure 6 Schematic view of one transfer unit in an extraction column for residual monomer reduction in a latex with $(\mathrm{sc}) \mathrm{CO}_{2}$.

In practice, intimate phase contact and reduced backmixing is achieved in a column including internals, e.g. a rotating disk contactor $(\mathrm{RDC})$ or a Karr reciprocating column. Including 
internals also supports the continuity of a small bubble size as well as of the width of the bubble size distribution (Gourdon, 1994, Kumar, 1994).

The mass transport coefficient of monomer in the $(\mathrm{sc}) \mathrm{CO}_{2}$ phase is then approximated according to Equation 11.

$\mathrm{k}_{\mathrm{m}}^{\mathrm{CO}_{2}}=2 * \sqrt{\frac{\mathrm{D}_{\mathrm{m}}^{\mathrm{CO}_{2}}}{\pi * \mathrm{t}_{\text {contact, } \mathrm{CO}_{2}}}}$

The mass transfer resistance depends on the specific area of the $\mathrm{H}_{2} \mathrm{O} /(\mathrm{sc}) \mathrm{CO}_{2}$ interface. Joly-Vuillemin and Bellefon (1999) suggest that the polymer particles partially cover the $\mathrm{H}_{2} \mathrm{O} /(\mathrm{sc}) \mathrm{CO}_{2}$ interface. The effective specific mass transfer area is then defined as

$\mathrm{a}_{\mathrm{eff}}(\mathrm{SF})=\mathrm{a}_{\mathrm{ij}} * \theta \quad$ for the shuttle effect

$a_{\text {eff }}(S L F)=a_{i j} *(1-\theta)$ for the SLF approach

Note that $\theta_{\max }$ is 0.74 , i.e. the maximum surface coverage by spherical particles in a three dimensional closest packing.

As mentioned earlier the SLF model is transport limited due to the resistance against monomer transport through the aqueous phase as a result of low monomer solubility in water (Zhang, 1997). In comparison with the SF mass transfer model, equilibrium cannot be reached within a short time. The shuttle effect is therefore dominating mass transfer. The mass transfer-in-series contribution is assumed to be negligible.

\section{Equipment design}

For extraction of residual monomer from a polystyrene (PS) latex by (sc) $\mathrm{CO}_{2}$ an empty non agitated extraction column is chosen, referred to as a bubble column. Latex (containing $45 \%$ solids) enters the column at the top with a throughput of $6000 \mathrm{~kg} / \mathrm{hr}$; the continuous latex flow is comparable to stripping a batch of 30 ton latex with steam in about 5 hours. Countercurrently $1 \mathrm{~mm}(\mathrm{sc}) \mathrm{CO}_{2}$ bubbles (specified by the sieve plate at the bottom of the column) are dispersed into the latex. Both the latex and the $(\mathrm{sc}) \mathrm{CO}_{2}$ flow have been considered to move through the column with negligible axial dispersion and perfect radial 
mixing, i.e. plug flow. Based on the results described in Chapter 3, the operating conditions of the bubble column have been chosen, leading to an operating pressure of 100 bar and an operating temperature of $35^{\circ} \mathrm{C}$. The partition coefficient of styrene between the PS latex and the $(\mathrm{sc}) \mathrm{CO}_{2}$ at the chosen operating conditions is $2\left[\mathrm{~kg} \mathrm{PS} / \mathrm{kg}(\mathrm{sc}) \mathrm{CO}_{2}\right]$. The lowest $(\mathrm{sc}) \mathrm{CO}_{2}$ flow rate, i.e. when the incoming latex and the outgoing $(\mathrm{sc}) \mathrm{CO}_{2}$ are at phase equilibrium (McCabe, 2001), to reduce the residual styrene level in the PS latex from $10^{4} \mathrm{ppm}$ to 100 ppm, to $10 \mathrm{ppm}$ and to $1 \mathrm{ppm}$, is approximately $1400 \mathrm{~kg} / \mathrm{hr}$, see Equation 14 and Figure 2. The lowest $(\mathrm{sc}) \mathrm{CO}_{2}$ flow rate applies in a column with an infinite number of stages.

$$
\begin{aligned}
& \phi_{\mathrm{CO}_{2}, \text { lowest }}=\phi_{\mathrm{p}} * \frac{\mathrm{C}_{\mathrm{m}, 0}^{\mathrm{p}}-\mathrm{C}_{\mathrm{m}, \mathrm{N}}^{\mathrm{p}}}{\mathrm{C}_{\mathrm{m}, 1}^{\mathrm{CO}}-\mathrm{C}_{\mathrm{m}, \mathrm{N}+1}^{\mathrm{CO}}}\left[\frac{\mathrm{m}^{3}}{\mathrm{hr}}\right] \\
& \text { with } \mathrm{C}_{\mathrm{m}, 1}^{\mathrm{CO}_{2}}=\mathrm{K}_{\mathrm{m}} * \mathrm{C}_{\mathrm{m}, 0}^{\mathrm{p}}
\end{aligned}
$$

Note that for reducing the residual methyl methacrylate (MMA) in a polymethyl methacrylate (PMMA) latex the lowest (sc) $\mathrm{CO}_{2}$ flow rate is about ${ }^{2} 9000 \mathrm{~kg} / \mathrm{hr}$. More (sc) $\mathrm{CO}_{2}$ is required to remove a similar amount of residual monomer from PMMA in comparison to the PS latex. This is due to the lower partition coefficient of MMA between PMMA latex and $(\mathrm{sc}) \mathrm{CO}_{2}$, i.e. $\mathrm{K}_{\mathrm{MMA}}=0.3\left[\mathrm{~kg} \mathrm{PMMA} / \mathrm{kg}(\mathrm{sc}) \mathrm{CO}_{2}\right]$ at 100 bar and $35^{\circ} \mathrm{C}$. The actual $(\mathrm{sc}) \mathrm{CO}_{2}$ flow rate has been calculated with Equations 14 and 3 and depends on the amount of monomer mass the extract phase may contain. A reduction from $10^{4} \mathrm{ppm}$ to $100 \mathrm{ppm}$, to $10 \mathrm{ppm}$ and to $1 \mathrm{ppm}$ corresponds (in this system) with $\sim 200$ mole Sty $/ \mathrm{m}^{3}$ (sc) $\mathrm{CO}_{2}$. The (sc) $\mathrm{CO}_{2}$ flow leaving the extraction column contains 200 mole Sty $/ \mathrm{m}^{3}(\mathrm{sc}) \mathrm{CO}_{2}$ for the minimum flow rate of $1400 \mathrm{~kg}$ $(\mathrm{sc}) \mathrm{CO}_{2} / \mathrm{hr}$. When it is specified that the outgoing $(\mathrm{sc}) \mathrm{CO}_{2}$ flow may contain only 90 mole $\mathrm{Sty} / \mathrm{m}^{3}$, a (sc) $\mathrm{CO}_{2}$ flow rate of $3050 \mathrm{~kg} / \mathrm{hr}$ is required. To obtain an exiting (sc) $\mathrm{CO}_{2}$ flow with a concentration of 50 mole Sty $/ \mathrm{m}^{3}(\mathrm{sc}) \mathrm{CO}_{2}, 5500 \mathrm{~kg}(\mathrm{sc}) \mathrm{CO}_{2} / \mathrm{hr}$ is necessary.

For designing the extraction column for residual monomer reduction in latex with $(\mathrm{sc}) \mathrm{CO}_{2}$ from $10^{4} \mathrm{ppm}$ to $100 \mathrm{ppm}$, to $10 \mathrm{ppm}$ and to $1 \mathrm{ppm}$, two approaches have been followed. In a first approach the number of theoretical stages required for the extraction have been determined based on the mass balance over one stage, see Equations 2 and 3 . The mass

\footnotetext{
${ }^{1}$ The lowest $\mathrm{CO}_{2}$ flow required for a residual styrene reduction in PS latex from $10^{4} \mathrm{ppm}$ to $100 \mathrm{ppm}$, to $10 \mathrm{ppm}$ and to $1 \mathrm{ppm}$ are slightly different, i.e. 1337,1349 and $1350 \mathrm{~kg} \mathrm{CO} / \mathrm{hr}$, respectively. The value of the $\mathrm{CO}_{2}$ flow indicated in the present work is somewhat higher to account for the $\mathrm{CO}_{2}$ that dissolves in the $\mathrm{H}_{2} \mathrm{O}$ phase.

${ }^{2}$ The lowest $\mathrm{CO}_{2}$ flow required for a residual MMA reduction in PMMA latex from $10^{4} \mathrm{ppm}$ to $100 \mathrm{ppm}$, to $10 \mathrm{ppm}$ and to $1 \mathrm{ppm}$ are slightly different, i.e. 8910,8990 and $8999 \mathrm{~kg} \mathrm{CO} / \mathrm{hr}$, respectively.
} 
balance over one stage is extended with the McCabe-Thiele method (McCabe, 2001), see e.g. Figure 7. The equilibrium line is straight as the partition coefficient is a constant, see section 'Partitioning'. The so-called operating line is always straight, the slope depends in general on the ratio of the liquid and the vapor (fluid) phase, i.e. the extraction performance. The monomer concentration in the entering latex phase as well as in the incoming $(\mathrm{sc}) \mathrm{CO}_{2}$ are known (i.e. $\mathrm{C}_{0}^{\mathrm{P}}=10^{4} \mathrm{ppm}$ and $\mathrm{C}_{\mathrm{N}+1}^{\mathrm{CO}_{2}}=0 \mathrm{ppm}$ ). The required monomer concentration in the latex phase leaving the column has been chosen (i.e. $\mathrm{C}_{\mathrm{N}}^{\mathrm{P}}=1 \mathrm{ppm}$ ) while the monomer level in the outgoing $(\mathrm{sc}) \mathrm{CO}_{2}$ depends on the ratio of the latex and the $\mathrm{CO}_{2}$ phase.

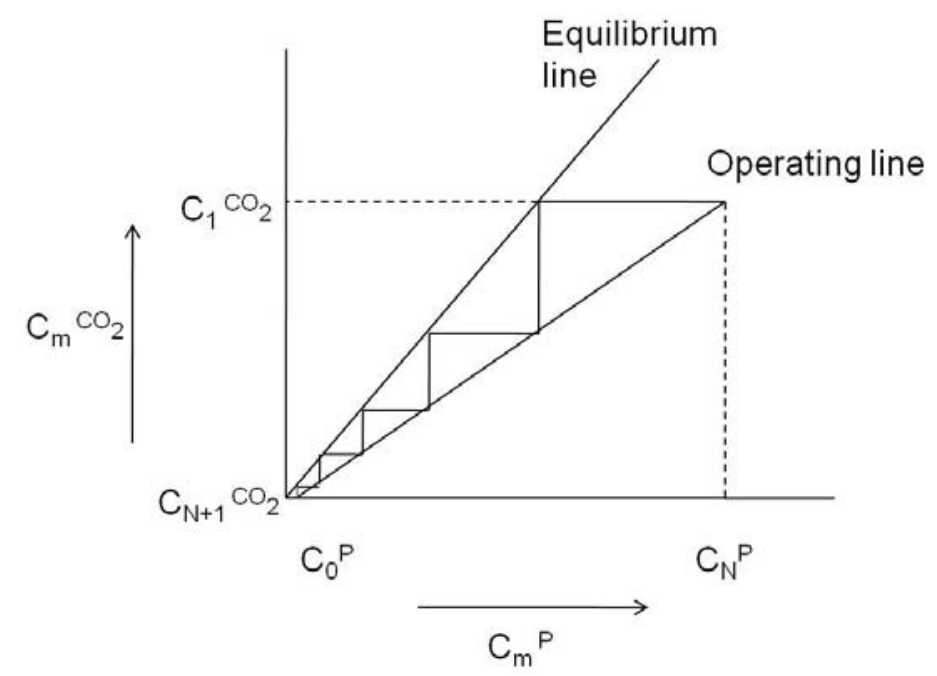

Figure 7 McCabe-Thiele diagram for the extraction of residual monomer in latex with (sc) $\mathrm{CO}_{2}$.

In a second approach the column dimensions have been determined with respect to a mass balance over the latex phase and the $(\mathrm{sc}) \mathrm{CO}_{2}$ phase, both in plug flow, in an infinitesimal slice of the column, see Figure 8 and Equations 16 and 17. 


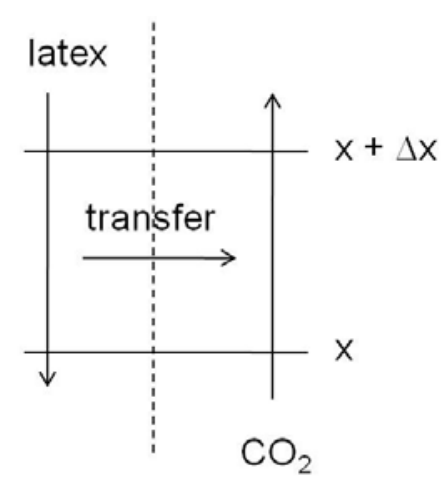

Figure 8 Schematic view of an infinitesimal piece $\Delta \mathrm{x}$ in an extraction column.

$$
\begin{array}{r}
0=\left.\varphi_{\mathrm{P}} * \mathrm{C}_{\mathrm{m}}^{\mathrm{P}}\right|_{\mathrm{x}+\Delta \mathrm{x}}-\left.\varphi_{\mathrm{P}} * \mathrm{C}_{\mathrm{m}}^{\mathrm{P}}\right|_{\mathrm{x}}+\left[\frac{1}{\mathrm{k}_{\mathrm{m}}^{\mathrm{P}}}+\frac{1}{\mathrm{~K}_{\mathrm{m}} * \mathrm{k}_{\mathrm{m}}^{\mathrm{CO}}}\right]^{-1} * \mathrm{a}_{\mathrm{CO}_{2}} * \theta^{*} \varepsilon_{\mathrm{CO}_{2}} * \\
\pi * \mathrm{r}_{\mathrm{c}}^{2} * \Delta \mathrm{x} *\left[\frac{\mathrm{C}_{\mathrm{m}}^{\mathrm{CO}_{2}}}{\mathrm{~K}_{\mathrm{m}}}-\mathrm{C}_{\mathrm{m}}^{\mathrm{P}}\right] \\
0=\left.\varphi_{\mathrm{CO}_{2}} * \mathrm{C}_{\mathrm{m}}^{\mathrm{CO}_{2}}\right|_{\mathrm{x}}-\left.\varphi_{\mathrm{CO}_{2}} * \mathrm{C}_{\mathrm{m}}^{\mathrm{CO}_{2}}\right|_{\mathrm{x}+\Delta \mathrm{x}}+\left[\frac{1}{\mathrm{k}_{\mathrm{m}}^{\mathrm{P}}}+\frac{1}{\mathrm{~K}_{\mathrm{m}}{ }^{\mathrm{C}} \mathrm{K}_{\mathrm{m}}}\right]^{-1} * \mathrm{a}_{\mathrm{CO}_{2}} * \theta * \varepsilon_{\mathrm{CO}_{2}} * \\
\pi * \mathrm{r}_{\mathrm{c}}^{2} * \Delta \mathrm{x} *\left[\mathrm{C}_{\mathrm{m}}^{\mathrm{P}}-\frac{\mathrm{C}_{\mathrm{m}}}{\mathrm{K}_{\mathrm{m}}}\right]
\end{array}
$$

Designing an extraction column, the separation performance but also the hydrodynamic characteristics, namely the dispersed phase hold up and bubble size, are key parameters in determining the column capacity and the required column diameter to provide the desired throughput and performance. First the influence of the dispersed phase hold up on the column design is discussed, followed by the effect of the bubble size.

\section{Dispersed phase hold up}

The drift-flux model reported by Wallis et al. (Wallis, 1969) has been applied to describe the flow characteristics in the latex-(sc) $\mathrm{CO}_{2}$ two-phase system. The drift flux is defined as the volume flux of the continuous phase with respect to the total volume flux (i.e. $v_{d}+v_{c}$ ). The drift-flux model is most importantly used to predict the flooding point (Xu, 1991). The drift-flux is proportional to the slip velocity. The slip velocity is the relative velocity of the dispersed 
phase with respect to the continuous phase. The slip velocity is expressed in terms of the effective velocities of the continuous and dispersed phase:

$\mathrm{v}_{\mathrm{s}}=\frac{\mathrm{v}_{\mathrm{d}}}{\varepsilon_{\mathrm{d}}}-\frac{\mathrm{v}_{\mathrm{c}}}{\left(1-\varepsilon_{\mathrm{d}}\right)}$

The superficial velocities of the dispersed as well as the continuous phase are defined as the ratio of the volumetric flux of the respective phase over the column area, see Equation 19.

$\mathrm{V}_{\mathrm{i}}=\frac{\phi_{\mathrm{v}, \mathrm{i}}}{\mathrm{A}_{\text {column }}}$

For solid (rigid spheres)-liquid systems, Richardson and Zaki (1954) experimentally determined the relationship between the slip velocity and the single sphere terminal settling/rising velocity $\left(\mathrm{v}_{\infty}\right)$, Equation 20 . Note that the slip velocity is also a function of the volume fraction of the dispersed phase in the column.

$\mathrm{v}_{\mathrm{s}}=\mathrm{v}_{\infty} *\left(1-\varepsilon_{\mathrm{d}}\right)^{\mathrm{n}-1}$

In Equation $20, \mathrm{n}$ is a function of the Reynolds number $\left(\mathrm{Re}=\frac{\mathrm{v}_{\infty} * \mathrm{~d}_{\mathrm{CO}_{2}} * \rho_{\text {latex }}}{\mu_{\text {latex }}}\right)$ for the rigid spheres, see Equations 21 to 24 (Richardson and Zaki, 1954).

$\operatorname{Re}<0.2$

$\mathrm{n}=4.65$

$0.2<\operatorname{Re}<1$

$\mathrm{n}=4.35 * \mathrm{Re}^{-0.03}$

$1<\operatorname{Re}<500$

$\mathrm{n}=4.45 * \mathrm{Re}^{-0.1}$

$\operatorname{Re}>500$

$\mathrm{n}=2.39$

The terminal rising velocity of one bubble is primarily controlled by buoyancy forces and the fluid drag, also a function of $\mathrm{Re}$, Equation 25. The derivation for Equation 23 from the force balance is found in Appendix A.

$\mathrm{v}_{\infty}=\sqrt{\frac{4 * \Delta \rho * \mathrm{~g} * \mathrm{~d}_{\mathrm{CO}_{2}}}{3 * \rho * \mathrm{C}_{\mathrm{D}}}}$

For low Reynolds numbers, (i.e. $\mathrm{Re}<1$, creep flow) the drag coefficient is $C_{\mathrm{D}}=\frac{24}{\mathrm{Re}_{\mathrm{CO}_{2}}}($ Bird et al., 2002).

Equations 18 and 20 become equal for two values of the dispersed phase hold up, a lower limit and un upper limit. The region between the hold up limits is assigned as stable working 
region. The column diameter then follows from Equation 18 for a given flow as the superficial velocity depends on the cross-sectional area of the column.

Evaluating the drift-flux model for the latex-(sc) $\mathrm{CO}_{2}$ system described above $\left(1 \mathrm{~mm} \mathrm{CO}_{2}\right.$ bubbles), the flooding point is assigned to a volume fraction of $(\mathrm{sc}) \mathrm{CO}_{2}$ in the column of $\varepsilon_{d}=0.3$. It is recommended that the actual value of the slip velocity should be taken at no more than $70 \%$ of the estimated slip velocity at the flooding point (Perry, 1999); in other words, the $(\mathrm{sc}) \mathrm{CO}_{2}$ hold up in the column is 0.2 . Most liquid-liquid extraction columns are operated at dispersed phase hold ups of $\varepsilon_{d}$ between 0.1 and 0.2 (Perry, 1999, Kumar, 1994).

Figure 9 shows the calculated $(\mathrm{sc}) \mathrm{CO}_{2}$ bubble residence times for a residual monomer reduction from $10^{4} \mathrm{ppm}$ to $100 \mathrm{ppm}$, to $10 \mathrm{ppm}$ and to $1 \mathrm{ppm}$ as a function of the fraction of the $\mathrm{H}_{2} \mathrm{O} / \mathrm{CO}_{2}$ interface covered with polymer particles. The $(\mathrm{sc}) \mathrm{CO}_{2}$ hold up is 0.2 , the diffusion coefficient $\left(\mathrm{D}_{\text {sty }}^{\mathrm{PS}}\right)$ of styrene in PS is $10^{-12} \frac{\mathrm{m}^{2}}{\mathrm{~s}}$, the $(\mathrm{sc}) \mathrm{CO}_{2}$ flow rate is a) $1400 \mathrm{~kg} / \mathrm{hr}$ (Equations 14 and 15), b) $3050 \mathrm{~kg} / \mathrm{hr}$ to $5500 \mathrm{~kg} / \mathrm{hr}$ (Equations 2 and 3).
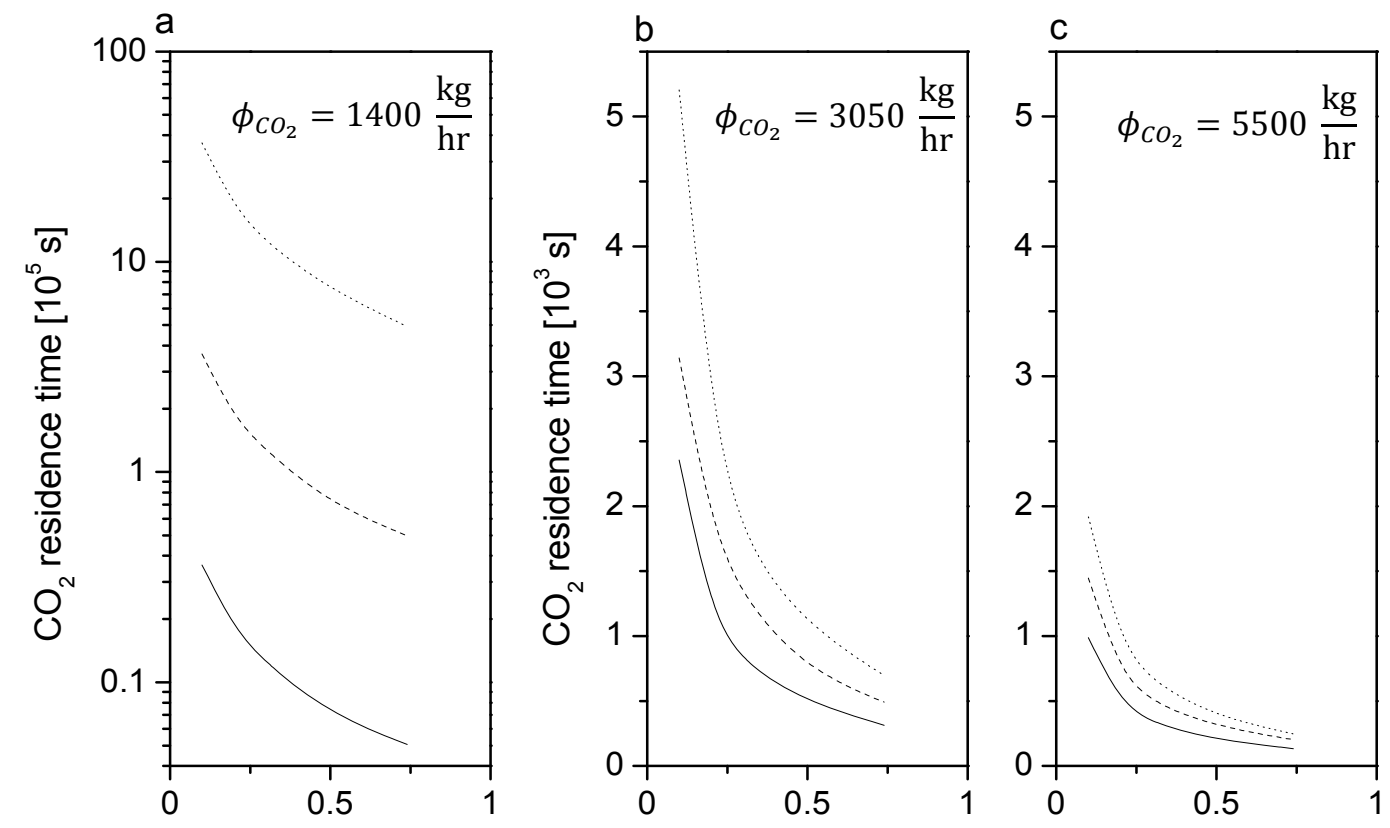

fraction of the $\mathrm{H}_{2} \mathrm{O} / \mathrm{CO}_{2}$ interface covered with polymer particles, $\theta[-]$

Figure $9 \mathrm{CO}_{2}$ bubble $(1 \mathrm{~mm})$ residence time for the extraction of Sty from PS at $35^{\circ} \mathrm{C}$ and 100 bar in function of the fraction of the $\mathrm{H}_{2} \mathrm{O} / \mathrm{CO}_{2}$ interface covered with polymer particles for different $(\mathrm{sc}) \mathrm{CO}_{2}$ flow rates. $\mathrm{K}_{\text {sty }}=2\left[\mathrm{~kg} \mathrm{PS} / \mathrm{kg} \mathrm{CO}\right.$ ] $; \varepsilon_{\mathrm{CO}_{2}}=0.2 ; \mathrm{D}_{\mathrm{c}}=1 \mathrm{~m} ; \mathrm{D}_{\text {sty }}^{\mathrm{PS}}=10^{-12} \frac{\mathrm{m}^{2}}{\mathrm{~s}}$, — $100 \mathrm{ppm}, \quad-\ldots 10 \mathrm{ppm}, \ldots . . . . . .1 \mathrm{ppm}$ residual monomer. 
Figure 9 shows that the fraction of the $\mathrm{H}_{2} \mathrm{O} / \mathrm{CO}_{2}$ interface covered with polymer particles affects the residence time of the $\mathrm{CO}_{2}$ bubbles (and therefore also the column volume) tremendously. Note that in Figure 9 the horizontal axis has a range of $0.1<\theta<0.74$. The upper limit is $\theta_{\max }=0.74$; the lower limit is arbitrarily chosen, according to the assumption that mass transport of monomer from polymer particles into the $(\mathrm{sc}) \mathrm{CO}_{2}$ phase is dominated by the shuttle effect. How many particles actually adsorb to the $\mathrm{H}_{2} \mathrm{O} / \mathrm{CO}_{2}$ interface depends on the interfacial tensions between $\mathrm{H}_{2} \mathrm{O}$ (with surfactant)/polymer, polymer/ $\mathrm{CO}_{2}$ and $\mathrm{H}_{2} \mathrm{O}$ (with surfactant) $/ \mathrm{CO}_{2}$ (Torza and Mason, 1970) and on the frequency the polymer particles arrive at and move away from the $\mathrm{H}_{2} \mathrm{O} / \mathrm{CO}_{2}$ interface. Predicting the number of particles adsorbed at the $\mathrm{H}_{2} \mathrm{O} / \mathrm{CO}_{2}$ interface according to the theory of Torza (1970), the upper limit value of 0.74 has been found.

As expected, increasing the $(\mathrm{sc}) \mathrm{CO}_{2}$ flow rate, Figures $9 \mathrm{a}$ to $9 \mathrm{c}$, decreases the monomer concentration in the exiting $(\mathrm{sc}) \mathrm{CO}_{2}$ flow, as well as the $\mathrm{CO}_{2}$ residence time in the column (and therefore also the column volume). For the lowest $(\mathrm{sc}) \mathrm{CO}_{2}$ flow rate, Figure $9 \mathrm{a}$, the actual column height is unrealistically high, i.e. $16 \mathrm{~m}$ for a residual monomer reduction from $10^{4} \mathrm{ppm}$ to $100 \mathrm{ppm}$ to $1600 \mathrm{~m}$ for a reduction from $10^{4} \mathrm{ppm}$ to $1 \mathrm{ppm}$ (at $\theta=0.74$ ). For a flow rate of 3050 and $5500 \mathrm{~kg}(\mathrm{sc}) \mathrm{CO}_{2} / \mathrm{hr}$, Figures $9 \mathrm{~b}$ and $9 \mathrm{c}$, acceptable column heights $(<4$ $\mathrm{m}$ ) have been calculated. Columns with an aspect ratio of about 3 are recommended, but columns with an aspect ratio between 2 and 5 are also common (Seider, 2010). Based on the aspect ratio in Figure 9b, (sc) $\mathrm{CO}_{2}$ flow rate of $3050 \mathrm{~kg} / \mathrm{hr}$, has been chosen as a base case in this work.

Tables 1 and 2 give the $\mathrm{CO}_{2}$ bubble residence times in the column at some values of the fraction of the $\mathrm{H}_{2} \mathrm{O} / \mathrm{CO}_{2}$ interface covered with polymer particles, for a (sc) $\mathrm{CO}_{2}$ or dispersed phase hold up of 0.2 and 0.1 . The $(\mathrm{sc}) \mathrm{CO}_{2}$ flow rate is $3050 \mathrm{~kg} / \mathrm{hr}$ and the column diameter is taken as $1 \mathrm{~m}$. The $1 \mathrm{~mm}(\mathrm{sc}) \mathrm{CO}_{2}$ bubbles (specified by a sieve plate in the column) rise through the column with a velocity of $1 \mathrm{~mm} / \mathrm{s}$ (i.e. the slip velocity or hindered rising velocity of the bubble swarm, calculated according to the drift flux approach, Equations 18 and 20). As mentioned in the introduction, the diffusion coefficient $\left(\mathrm{D}_{\text {sty }}^{\mathrm{PS}}\right)$ of monomer in the polymer phase increases from $10^{-15} \frac{\mathrm{m}^{2}}{\mathrm{~s}}$ to $10^{-12} \frac{\mathrm{m}^{2}}{\mathrm{~s}}<\mathrm{D}_{\text {sty }}^{\mathrm{PS}}<10^{-11} \frac{\mathrm{m}^{2}}{\mathrm{~s}}$ due to the plasticizing effect of $\mathrm{CO}_{2}$ (Alsoy, 1998). To analyze the effect of the transport constant of styrene in the polymer 
phase, the $\mathrm{CO}_{2}$ residence time has been calculated for $\mathrm{D}_{\text {sty }}^{\mathrm{PS}}=10^{-12} \frac{\mathrm{m}^{2}}{\mathrm{~s}}$ and for $\mathrm{D}_{\text {sty }}^{\mathrm{PS}}=$ $10^{-11} \frac{\mathrm{m}^{2}}{\mathrm{~s}}$.

Table $1(\mathrm{sc}) \mathrm{CO}_{2}$ bubble residence time for operation with a $\mathrm{CO}_{2}$ hold up $\left(\varepsilon_{\mathrm{d}}\right)$ of 0.2 for a residual monomer reduction from $10^{4} \mathrm{ppm}$ to $100 \mathrm{ppm}$, to $10 \mathrm{ppm}$ and to $1 \mathrm{ppm}$ as a function of the fraction of the $\mathrm{H}_{2} \mathrm{O} / \mathrm{CO}_{2}$ interface covered with polymer particles. *

\begin{tabular}{c|c|c|c|c|c|c}
\hline & \multicolumn{3}{|c|}{$\mathrm{D}_{\text {sty }}^{\text {PS }}=10^{-12}\left[\frac{\mathrm{m}^{2}}{\mathrm{~s}}\right]$} & \multicolumn{3}{|c}{$\mathrm{D}_{\text {sty }}^{\text {PS }}=10^{-11}\left[\frac{\mathrm{m}^{2}}{\mathrm{~s}}\right]$} \\
\hline \hline 0.74 & $\tau_{100}[\mathrm{~s}]$ & $\tau_{10}[\mathrm{~s}]$ & $\tau_{1}[\mathrm{~s}]$ & $\tau_{100}[\mathrm{~s}]$ & $\tau_{10}[\mathrm{~s}]$ & $\tau_{1}[\mathrm{~s}]$ \\
\hline 0.3 & 314 & 491 & 697 & 196 & 295 & 403 \\
\hline
\end{tabular}

operating conditions: 100 bar, $35^{\circ} \mathrm{C}, \mathrm{K}_{\mathrm{sty}}=2\left[\mathrm{~kg} \mathrm{PS} / \mathrm{kg} \mathrm{CO}\right.$ ], column diameter $\mathrm{D}_{\mathrm{c}}=1 \mathrm{~m}, \phi_{\mathrm{CO}_{2}}=3050 \mathrm{~kg} / \mathrm{hr}$, $d_{\mathrm{CO}_{2}}=1 \mathrm{~mm}$

Table $2(\mathrm{sc}) \mathrm{CO}_{2}$ bubble residence time for operation with a $\mathrm{CO}_{2}$ hold up $\left(\varepsilon_{\mathrm{d}}\right)$ of 0.1 for a residual monomer reduction from $10^{4} \mathrm{ppm}$ to $100 \mathrm{ppm}$, to $10 \mathrm{ppm}$ and to $1 \mathrm{ppm}$ as a function of the fraction of the $\mathrm{H}_{2} \mathrm{O} / \mathrm{CO}_{2}$ interface covered with polymer particles.

\begin{tabular}{|c|c|c|c|c|c|c|}
\hline \multirow[b]{2}{*}{$\theta[-]$} & \multicolumn{3}{|c|}{$\mathrm{D}_{\mathrm{sty}}^{\mathrm{PS}}=10^{-12}\left[\frac{\mathrm{m}^{2}}{\mathrm{~s}}\right]$} & \multicolumn{3}{|c|}{$\mathrm{D}_{\text {sty }}^{\mathrm{PS}}=10^{-11}\left[\frac{\mathrm{m}^{2}}{\mathrm{~s}}\right]$} \\
\hline & $\tau_{100}[\mathrm{~s}]$ & $\tau_{10}[\mathrm{~s}]$ & $\tau_{1}[\mathrm{~s}]$ & $\tau_{100}[\mathrm{~s}]$ & $\tau_{10}[\mathrm{~s}]$ & $\tau_{1}[\mathrm{~s}]$ \\
\hline 0.74 & 589 & 982 & 1374 & 363 & 589 & 785 \\
\hline 0.3 & 1571 & 2556 & 3436 & 982 & 1473 & 1963 \\
\hline
\end{tabular}

For a $(\mathrm{sc}) \mathrm{CO}_{2}$ hold up of $10 \%$, a bubble residence time in the column more than twice the time at a hold up of $20 \%$ is necessary to absorb the desired amount of monomer. Consequently, the column height increases with approximately a factor 4 , resulting in an aspect ratio far above 5 . Table 3 provides the calculated column heights corresponding to the $\mathrm{CO}_{2}$ residence times reported in Tables 1 and 2. Only the column heights at the highest 
possible fraction of the $\mathrm{H}_{2} \mathrm{O} / \mathrm{CO}_{2}$ interface covered with polymer particles $(\theta=0.74)$ are given.

Table 3 Column height for a residual monomer reduction from $10^{4} \mathrm{ppm}$ to $100 \mathrm{ppm}$, to 10 ppm and to $1 \mathrm{ppm}$ as function of the dispersed phase hold up for $\theta=0.74$.

\begin{tabular}{c|c|c|c|c|c|c}
\hline & \multicolumn{3}{|c|}{$\mathrm{D}_{\text {sty }}^{\mathrm{PS}}=10^{-12}\left[\frac{\mathrm{m}^{2}}{\mathrm{~s}}\right]$} & \multicolumn{3}{|c}{$\mathrm{D}_{\text {sty }}^{\mathrm{PS}}=10^{-11}\left[\frac{\mathrm{m}^{2}}{\mathrm{~s}}\right]$} \\
$\varepsilon_{C O_{2}}[-]$ & $\mathrm{H}_{\mathrm{c}, 100}[\mathrm{~m}]$ & $\mathrm{H}_{\mathrm{c}, 10}[\mathrm{~m}]$ & $\mathrm{H}_{\mathrm{c}, 1}[\mathrm{~m}]$ & $\mathrm{H}_{\mathrm{c}, 100}[\mathrm{~m}]$ & $\mathrm{H}_{\mathrm{c}, 10}[\mathrm{~m}]$ & $\mathrm{H}_{\mathrm{c}, 1}[\mathrm{~m}]$ \\
\hline \hline 0.2 & 1.6 & 2.5 & 3.6 & 1 & 1.5 & 2 \\
\hline 0.1 & 6 & 10 & 14 & 3.7 & 6 & 8 \\
\hline
\end{tabular}

operating conditions: 100 bar, $35^{\circ} \mathrm{C}, \mathrm{K}_{\text {sty }}=2\left[\mathrm{~kg} \mathrm{PS} / \mathrm{kg} \mathrm{CO}\right.$ ], column diameter $\mathrm{D}_{\mathrm{c}}=1 \mathrm{~m}, \phi_{\mathrm{CO}_{2}}=3050 \mathrm{~kg} / \mathrm{hr}$, $d_{\mathrm{CO}_{2}}=1 \mathrm{~mm}$

As a result, from here on the dispersed phase hold up of 0.2 is chosen in further designing the extraction column.

Tables 1 to 3 indicate that an increase of the diffusion coefficient of Sty in the polymer phase by only a factor 10 strongly affects the $\mathrm{CO}_{2}$ residence time as well as the column volume. The transport coefficient $\left(\mathrm{k}_{\mathrm{sty}}^{\mathrm{PS}}\right)$ of styrene in PS improves from $7 * 10^{-5}\left[\frac{\mathrm{m}}{\mathrm{s}}\right]$ to $9.9 * 10^{-4}\left[\frac{\mathrm{m}}{\mathrm{s}}\right]$ when the diffusion coefficient $\left(D_{\text {sty }}^{\text {PS }}\right)$ of styrene in PS increases from $10^{-12}\left[\frac{\mathrm{m}^{2}}{\mathrm{~s}}\right]$ to $10^{-11}\left[\frac{\mathrm{m}^{2}}{\mathrm{~s}}\right]$ (calculated with Equation 8 for $100 \mathrm{~nm}$ polymer particles). The polymer particles are depleted of monomer very fast when contacting a $\mathrm{CO}_{2}$ bubble. From here on the column is designed for a diffusion coefficient of styrene in $\mathrm{CO}_{2}$ swollen PS of $10^{-12}\left[\frac{\mathrm{m}^{2}}{\mathrm{~s}}\right]$, the worst case scenario' upon swelling the polymer particles with $\mathrm{CO}_{2}$ (Alsoy, 1998).

\section{Bubble size}

Kumar (1994) and Gourdon (1994) emphasize the importance of the drop-size distribution in designing extraction columns. The dispersed phase generally enters the column via a distribution plate (i.e. sieve plate). The inlet drop-size distribution is thus determined by the size of the sieve holes and dispersed phase throughput. Depending on the column type, a 
steady drop-size distribution can be established, i.e. the drop-size distribution is practically independent of the axial position in the column length. Therefore, an average drop size is used to describe the extraction column. Kumar et al. $(1996,1994)$ give an overview of the unified correlations for predicting drop or bubble sizes of several kinds of liquid-liquid extraction columns. The predictions have been based upon experimental data obtained with a well defined column diameter and column height. Korchinsky (1994) found that smaller drops or bubbles require larger column diameters, because of a lower slip velocity relative to the continuous phase. At the same time smaller drops provide larger specific interfacial surface area, higher mass transfer rates and therefore columns become shorter. However, a larger column diameter results in more axial dispersion in the column, hence decreasing mass transfer (Godfrey, 1994). The axial mixing of the continuous phase is caused by the tendency of the droplets to concentrate in the center of the column and move up together with a core of continuous phase, which returns to the bottom through an annulus around the wall, see Figure 10.

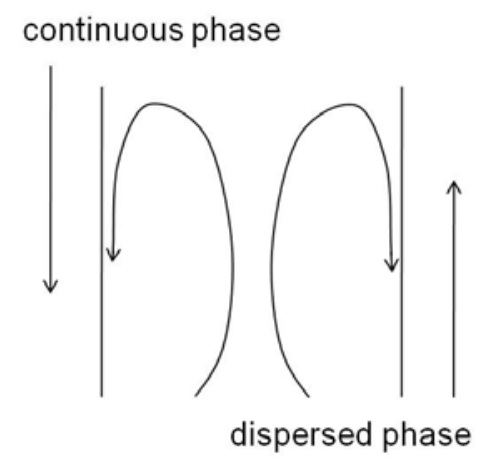

Figure 10 Schematic view of the axial mixing of the continuous phase in an extraction column induced by the dispersed phase.

In the present work, the average bubble size as well as the column diameter have been defined, with respect to the flooding conditions according to the Wallis drift-flux model. From these data the corresponding $\mathrm{CO}_{2}$ residence time and column height have been calculated. Table 4 collects the $\mathrm{CO}_{2}$ residence time as well as the column height required for a residual monomer reduction from $10^{4} \mathrm{ppm}$ to $100 \mathrm{ppm}$, to $10 \mathrm{ppm}$ and to $1 \mathrm{ppm}$ for 3 different diameters of the $\mathrm{CO}_{2}$ bubbles. 
Table $4 \mathrm{CO}_{2}$ residence time and the corresponding column height for a residual monomer reduction from $10^{4} \mathrm{ppm}$ to $100 \mathrm{ppm}$, to $10 \mathrm{ppm}$ and to $1 \mathrm{ppm}$ in function of the $\mathrm{CO}_{2}$ bubble diameter for $\theta=0.74^{*}$

\begin{tabular}{c|c|c|c|c|c|c}
\hline$d_{\mathrm{CO}_{2}}\left[10^{-3} \mathrm{~m}\right]$ & $\tau_{100}[\mathrm{~s}]$ & $\tau_{10}[\mathrm{~s}]$ & $\tau_{1}[\mathrm{~s}]$ & $\mathrm{H}_{\mathrm{c}, 100}[\mathrm{~m}]$ & $\mathrm{H}_{\mathrm{c}, 10}[\mathrm{~m}]$ & $\mathrm{H}_{\mathrm{c}, 1}[\mathrm{~m}]$ \\
\hline \hline 0.5 & 98 & 147 & 216 & 0.5 & 0.75 & 1.1 \\
\hline 1 & 314 & 491 & 697 & 1.6 & 2.5 & 3.6 \\
\hline 2 & 589 & 942 & 1306 & 3 & 4.8 & 6.7 \\
\hline
\end{tabular}

*operating conditions: $100 \mathrm{bar}, 35^{\circ} \mathrm{C}, \mathrm{K}_{\mathrm{sty}}=2\left[\mathrm{~kg} \mathrm{PS} / \mathrm{kg} \mathrm{CO}\right.$ ], column diameter $\mathrm{D}_{\mathrm{c}}=1 \mathrm{~m}, \phi_{\mathrm{CO}_{2}}=3050 \mathrm{~kg} / \mathrm{hr}$, $\mathrm{D}_{\mathrm{sty}}^{\mathrm{PS}}=10^{-12}\left[\mathrm{~m}^{2} / \mathrm{s}\right], \varepsilon_{\mathrm{CO}_{2}}=0.2$

Increasing the bubble diameter results in higher $\mathrm{CO}_{2}$ residence times and larger columns, similar to the findings of Korchinsky (1994), as mentioned above. The mass transfer coefficient $\left(\mathrm{k}_{\text {sty }}^{\mathrm{CO}_{2}}\right)$ of styrene in the $\mathrm{CO}_{2}$ bubble decreases with increasing bubble size. Table 5 shows the required contact time of a $\mathrm{CO}_{2}$ bubble with a polymer particle for a developed concentration profile in the $\mathrm{CO}_{2}$ bubble, calculated with Equation 10, as well as the mass transfer coefficient $\left(\mathrm{k}_{\text {sty }}^{\mathrm{CO}_{2}}\right)$ of styrene in a $\mathrm{CO}_{2}$ bubble, calculated with Equation 11, with respect to the contact time for 3 different bubble sizes.

Table 5 Contact time of a $\mathrm{CO}_{2}$ bubble with a polymer particle for a developed concentration profile in the $\mathrm{CO}_{2}$ bubble, calculated with Equation 10, and the corresponding mass transfer coefficient of styrene in the $\mathrm{CO}_{2}$ phase, calculated with Equation 11, as a function of the $\mathrm{CO}_{2}$ bubble size for $\theta=0.74^{*}$

\begin{tabular}{c|c|c}
\hline $\mathrm{d}_{\mathrm{CO}_{2}}\left[10^{-3} \mathrm{~m}\right]$ & $\mathrm{t}_{\mathrm{contact}^{\mathrm{CO}} \mathrm{CO}_{2}}[\mathrm{~s}]$ & $\mathrm{k}_{\mathrm{sty}}^{\mathrm{CO}_{2}}\left[10^{-5} \frac{\mathrm{m}}{\mathrm{s}}\right]$ \\
\hline \hline 0.5 & 2 & 10 \\
\hline 1 & 7 & 5 \\
\hline 2 & 29 & 2.5 \\
\hline
\end{tabular}

operating conditions: 100 bar, $35^{\circ} \mathrm{C}, \mathrm{K}_{\text {sty }}=2\left[\mathrm{~kg} \mathrm{PS} / \mathrm{kg} \mathrm{CO}\right.$ ], column diameter $\mathrm{D}_{\mathrm{c}}=1 \mathrm{~m}, \phi_{\mathrm{CO}_{2}}=3050 \mathrm{~kg} / \mathrm{hr}$, $\mathrm{D}_{\mathrm{sty}}^{\mathrm{PS}}=10^{-12}\left[\mathrm{~m}^{2} / \mathrm{s}\right], \varepsilon_{\mathrm{CO}_{2}}=0.2$

Large drops are internally well mixed, whereas small drops show an extra internal circulation modifying the rigidity of the drop, i.e. the Marangoni effect, suppressing the benefit of a 
higher mass transfer rate in the dispersed phase (Bird, 2002). A bubble of $1 \mathrm{~mm}$ in diameter with a slip velocity of $\sim 1 \mathrm{~mm} / \mathrm{s}$ is considered to be of realistic dimensions.

With respect to the mass balance over one stage, see Equation 2, extended over the total height of the extraction column, the number of theoretical stages has been determined, see Figure 2. It has been found that 12 equilibrium stages apply to reduce the residual monomer in the latex from $10^{4} \mathrm{ppm}$ to $1 \mathrm{ppm}$. Knowing the number of stages required for the extraction as well as the column height, the height equivalent of a theoretical stage follows from Equation 26.

$\mathrm{H}_{\mathrm{c}}=\mathrm{N}_{\mathrm{ts}} * \mathrm{H}_{\mathrm{HETP}}$

Table 6 provides an overview of the operating conditions, design parameters and column dimensions for the reduction of residual styrene in a PS latex from $10^{4} \mathrm{ppm}$ to $1 \mathrm{ppm}$ by extraction with $\mathrm{scCO}_{2}$. 
Table 6 Operating conditions, design parameters and column dimensions for the high pressure $\mathrm{CO}_{2}$ extraction of residual monomer from $10^{4} \mathrm{ppm}$ to $1 \mathrm{ppm}$.

\section{Operating conditions}

\begin{tabular}{l|c}
\hline \hline pressure, $\mathrm{P}[\mathrm{bar}]$ & 100 \\
\hline temperature, $\mathrm{T}\left[{ }^{\circ} \mathrm{C}\right]$ & 35 \\
\hline latex throughput, $\phi_{\text {latex }}[\mathrm{kg} / \mathrm{hr}]$ & 6000 \\
\hline $\mathrm{CO}_{2}$ throughput, $\phi_{\mathrm{CO}_{2}}[\mathrm{~kg} / \mathrm{hr}]$ & 3050 \\
\hline partition coefficient, $\mathrm{K}_{\text {sty }}\left[\mathrm{kg} \mathrm{PS} / \mathrm{kg}(\mathrm{sc}) \mathrm{CO}_{2}\right]$ & 2 \\
\hline diffusion coefficient of styrene in $\mathrm{CO}_{2}$-swollen $\mathrm{PS}, \mathrm{D}_{\text {sty }}^{\mathrm{PS}}\left[\mathrm{m}^{2} / \mathrm{s}\right]$ & $10^{-12}$ \\
\hline
\end{tabular}

\section{Column dimensions}

\begin{tabular}{l|c}
\hline \hline column diameter, $\mathrm{D}_{\mathrm{c}}[\mathrm{m}] \quad(+15 \%$ marge $)$ & 1.2 \\
\hline column height, $\mathrm{H}_{\mathrm{c}}[\mathrm{m}] \quad(+15 \%$ marge $)$ & 4.2 \\
\hline number of theoretical stages, $\mathrm{N}_{\mathrm{ts}}$ & 12 \\
\hline height equivalent of a theoretical plate, $\mathrm{H}_{\mathrm{HETP}}[\mathrm{m}]$ & 0.35 \\
\hline
\end{tabular}

\section{Design parameters}

\begin{tabular}{c|c}
\hline \hline dispersed phase hold up, $\varepsilon_{\mathrm{CO}_{2}}\left[\mathrm{~m}_{\mathrm{CO}_{2}}^{3} / \mathrm{m}_{\text {column }}^{3}\right]$ & 0.2 \\
\hline bubble diameter, $\mathrm{d}_{\mathrm{CO}_{2}}[\mathrm{~mm}]$ & 1 \\
\hline
\end{tabular}

After the extraction, styrene (the extract) needs to be separated from (sc) $\mathrm{CO}_{2}$ in order to recycle the extraction fluid. In a first step, by tuning the pressure of the styrene/ $\mathrm{CO}_{2}$ mixture, a great part of the styrene is liquefied containing a small amount of liquid $\mathrm{CO}_{2}$. Note that in the binary phase diagram of styrene and $\mathrm{CO}_{2}$ (Zhang, 2005, Chapter 3 ) one can see that depressurizing the homogeneous styrene $/ \mathrm{CO}_{2}$ mixture at $35{ }^{\circ} \mathrm{C}$ from 100 bar to 60 bar, a liquid phase containing $40 \% \mathrm{CO}_{2}$ and $60 \%$ styrene and a gas phase existing of $\sim 99 \% \mathrm{CO}_{2}$ and $\sim 1 \%$ styrene appear. In terms of flow rates and concentrations the mixture is separated into a gas stream of $3035 \mathrm{~kg} \mathrm{CO} / \mathrm{hr}$ containing $40 \mathrm{ppm}$ styrene and a liquid stream of about $24 \mathrm{~kg} / \mathrm{hr}$ styrene and $15 \mathrm{~kg} / \mathrm{hr} \mathrm{CO}_{2}$. The $\mathrm{CO}_{2}$ in the liquid phase is lost for the purpose of recycling. Decreasing pressure below 60 bar and/or increasing temperature above $35{ }^{\circ} \mathrm{C}$ 
decreases the amount of liquid $\mathrm{CO}_{2}$ in the waste stream. The concentration of styrene in the gaseous $\mathrm{CO}_{2}$ leaving the separator is very small but the $\mathrm{CO}_{2}$ still needs to be further purified before recycling. The energy consumption and equipment costs to separate the styrene $/ \mathrm{CO}_{2}$ mixture such that the liquid phase contains less $\mathrm{CO}_{2}$, are much higher than adding $15 \mathrm{~kg}$ new $\mathrm{CO}_{2} / \mathrm{hr}$ to the recycle stream. So the operating conditions of the separation step are $35{ }^{\circ} \mathrm{C}$ and 60 bar. $^{3}$ It is suggested that in the top of separation vessel a demister is included to prevent entrainment of liquid droplets.

In a second step the styrene $(\sim 40 \mathrm{ppm})$ is suggested to be removed from the gaseous $\mathrm{CO}_{2}$ flow by means of catalytic oxidation with oxygen (stoechiometric amount). The styrene/ $\mathrm{CO}_{2}$ mixture is led over a fixed bed of Platinum (Pt) catalyst on a silica or alumina support in a nitrogen-free environment. The styrene is completely converted into $\mathrm{CO}_{2}$ and $\mathrm{H}_{2} \mathrm{O}$. The oxidation is exothermic but requires some heat to start. The operating conditions in the oxidation step have been chosen at 60 bar and $80{ }^{\circ} \mathrm{C}$. The amount of catalyst needed has been estimated at $180 \mathrm{~kg}$ when the $\mathrm{M}_{\text {cat }} / \phi_{\text {styrene }+\mathrm{O}_{2}}$ ratio is approximately $1 \mathrm{~g} / \mathrm{molhr}^{-1}$ (for a production capacity of $50 \mathrm{kt}$ PS latex (45\% solids)/yr). For more information concerning the catalytic oxidation step the reader is referred to specialized literature (Seki, 2009, Evonik Industries, 2011).

The purified latex or raffinate phase contains $1 \mathrm{ppm}$ styrene but is still swollen with $\mathrm{CO}_{2}$ at a pressure of 100 bar. Depressurizing the $\mathrm{CO}_{2}$-swollen latex is a key and delicate step as the colloidal stability of the latex may change under pressure relief, i.e. foaming, coagulation, etc.. These concerns are addressed in the next chapter.

\section{Process flow diagram}

Figure 11 shows the process flow diagram (PFD) for the reduction of the residual styrene content in a PS latex from $10^{4} \mathrm{ppm}$ to $1 \mathrm{ppm}$ by extraction with high pressure $\mathrm{CO}_{2}$. The

\footnotetext{
${ }^{3}$ In the available binary phase diagrams of styrene- $\mathrm{CO}_{2}$ increasing the temperature to $75{ }^{\circ} \mathrm{C}$ (at 100 bar) (Suppes, 1989, Akgun, 2004) also creates a phase separation into a liquid phase containing $40 \% \mathrm{CO}_{2}$ but it appears that the mixture existing out of $98 \% \mathrm{CO}_{2}$ is homogeneous at these conditions and phase separation will not occur. Accurate experimental data are necessary to verify this observation. When a phase separation of $40 \%$ liquid and $99.5 \%$ gaseous $\mathrm{CO}_{2}$ can be achieved at $75^{\circ} \mathrm{C}$ and 100 bar, the recompression of the $\mathrm{CO}_{2}$ recycle and therefore also the expensive compressor are no longer required. The overall cost and energy consumption decreases in comparison to the processes presented in the present section.
} 
respective streams entering and leaving the various pieces of equipment are indicated in Figure 11a. The required work or power to heat or compress the streams are also given in this figure, based on the information in Table 6 .

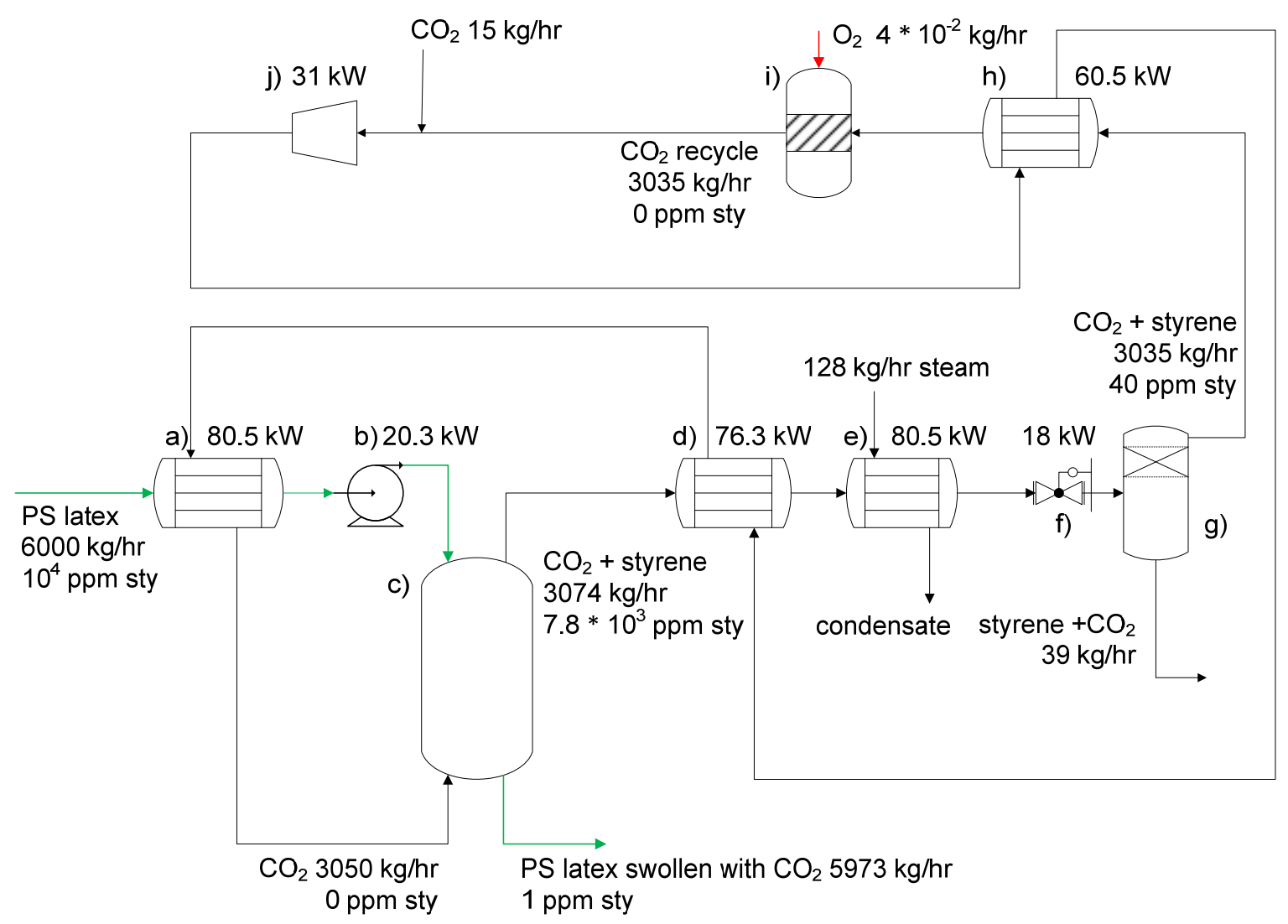

Figure 11a Process flow diagram for the reduction of residual styrene in polystyrene latex from $10^{4} \mathrm{ppm}$ to $1 \mathrm{ppm}$ by extraction with $\mathrm{scCO}_{2}$ at 100 bar and $35^{\circ} \mathrm{C}$. a) heat exchanger 1 , b) pump, c) extraction column, d) heat exchanger 2, e) heat exchanger 3, f) pressure reducer, g) separator with demister, $\mathrm{h}$ ) heat exchanger 4 , i) catalytic oxidation, j) compressor. Green line represents latex circuit; black line represents $\mathrm{CO}_{2}$ circuit; red line represents the $\mathrm{O}_{2}$ stream.

Two separate circuits are distinguished in the PFD: one for latex and one for $(\mathrm{sc}) \mathrm{CO}_{2}$. Latex enters the circuit at 1 bar and $15^{\circ} \mathrm{C}$. As the extraction conditions are 100 bar and $35^{\circ} \mathrm{C}$, the latex stream is heated (a) and pressurized (b). After extraction a purified latex product is obtained. 
$\mathrm{CO}_{2}$ follows a more complicated circuit. After extraction of the latex, a styrene/ $\mathrm{CO}_{2}$ mixture is obtained, leaving the extraction column at $35^{\circ} \mathrm{C}$ and 100 bar. As previously mentioned, the separation step $(\mathrm{g}$ ) requires a pressure decrease to 60 bar. In the Mollier diagram by Planck and Kuprianoff, see Appendix C, one can see that isentropic depressurizing decreases the temperature tremendously. ${ }^{4}$ Before separating the styrene from the $\mathrm{CO}_{2}$, the mixture needs to be heated to $72{ }^{\circ} \mathrm{C}$ in order to allow the separator to operate at $35^{\circ} \mathrm{C}$ and 60 bar. Before entering the oxidation vessel (i) an isobaric temperature increase from $35{ }^{\circ} \mathrm{C}$ to $80{ }^{\circ} \mathrm{C}$ is required. The purified $\mathrm{CO}_{2}$ at 60 bar and $80{ }^{\circ} \mathrm{C}$ is mixed with some fresh $\mathrm{CO}_{2}$ at 55 bar and $15{ }^{\circ} \mathrm{C}$. The amount of fresh $\mathrm{CO}_{2}$ is less than $1 \%$ of the total $\mathrm{CO}_{2}$ required for extraction, so there will be no significant influence on the temperature and pressure of the recycled $\mathrm{CO}_{2}$ stream. A compressor (j) isentropically pressurizes the $\mathrm{CO}_{2}$ to 100 bar, increasing the temperature to $120^{\circ} \mathrm{C}$, see Mollier diagram, Appendix $\mathrm{C}$. The energy flux of the $\mathrm{CO}_{2}$ stream at $120{ }^{\circ} \mathrm{C}$ is very high, due to the relatively high heat capacity ${ }^{5}$ of dense $\mathrm{CO}_{2}$, and can be used to heat the latex (a), the $\mathrm{CO}_{2}$ at the oxidation vessel $(\mathrm{h})$ and partly the $\mathrm{CO}_{2}$ going to the styrene/ $/ \mathrm{CO}_{2}$ separator (d). Complementary heating the $\mathrm{CO}_{2}$ at the separator is achieved by means of steam (e).

Figure $11 \mathrm{~b}$ shows the complementary temperatures and pressures of the equipment in Figure 11a.

\footnotetext{
${ }^{4}$ As the amount of styrene in the styrene/ $\mathrm{CO}_{2}$ mixture is so low, it has negligible influence on the behavior of $\mathrm{CO}_{2}$. ${ }^{5}$ At 100 bar at $35^{\circ} \mathrm{C}$ the specific heat of $\mathrm{CO}_{2}$ is $4.7 \mathrm{~kJ} / \mathrm{kg}{ }^{\circ} \mathrm{C}$ (deducted from the Mollier diagram, Appendix C).
} 


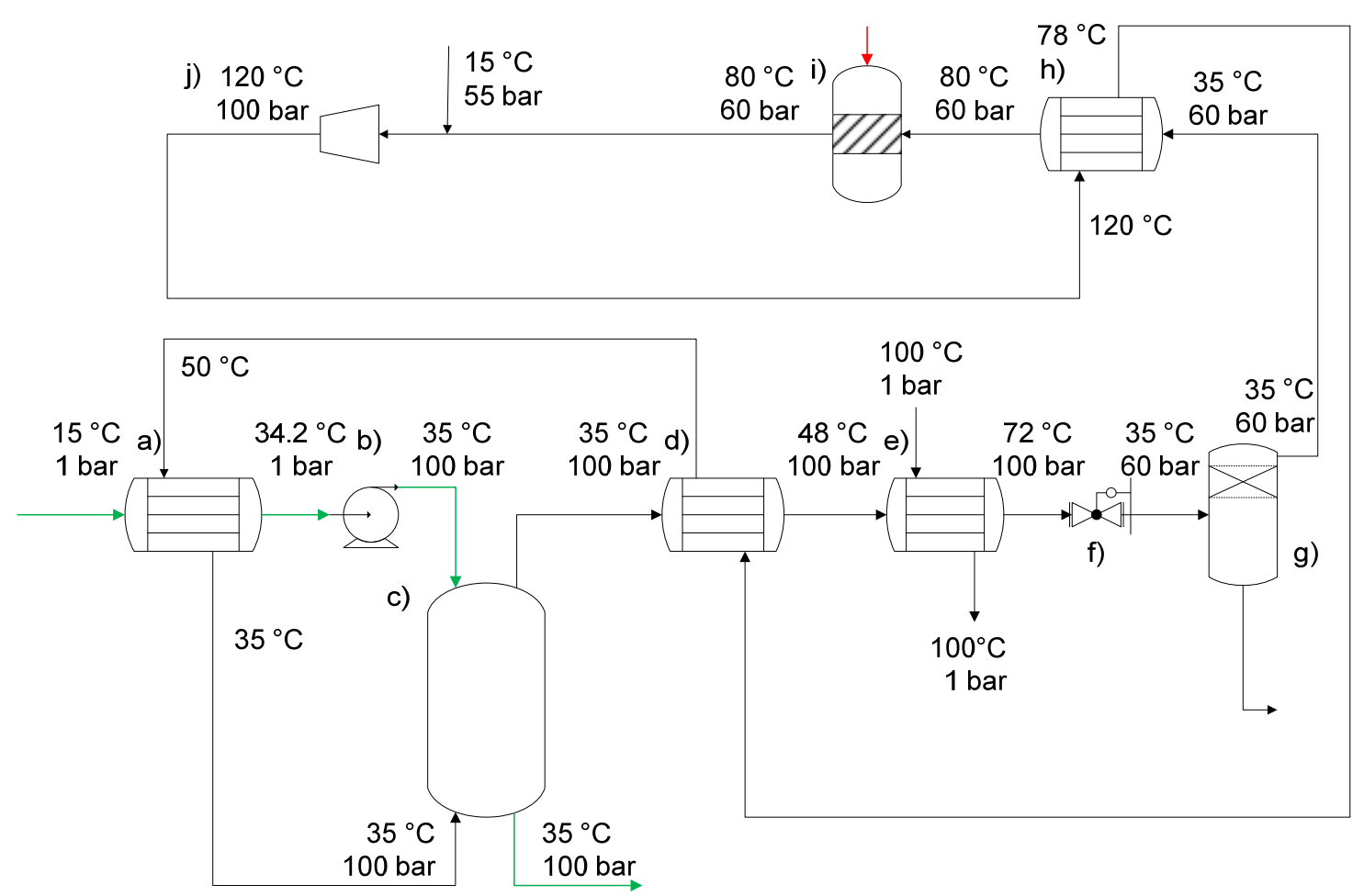

Figure 11b Temperature and pressure profiles corresponding with the PFD of the reduction of residual styrene in polystyrene latex from $10^{4} \mathrm{ppm}$ to $1 \mathrm{ppm}$ by extraction with $\mathrm{scCO}_{2}$ at 100 bar and $35^{\circ} \mathrm{C}$ shown in figure $7 \mathrm{a}$. a) heat exchanger $1, \mathrm{~b}$ ) pump, c) extraction column, d) heat exchanger 2 , e) heat exchanger 3, f) pressure reducer, g) separator with demister, $h$ ) heat exchanger 4, i) catalytic oxidation, j) compressor. Green line represents the latex circuit; black line represents the $\mathrm{CO}_{2}$ circuit; red line represents the $\mathrm{O}_{2}$ stream.

Designing the $(\mathrm{sc}) \mathrm{CO}_{2}$-based extraction process, calculations have been performed assuming that the latex phase is swollen with $(\mathrm{sc}) \mathrm{CO}_{2}$, so the molecular diffusion coefficient of styrene in $\mathrm{CO}_{2}$-swollen PS $\left(\mathrm{D}_{\text {sty }}^{\mathrm{PS}}\right)$ is $10^{-12}\left[\frac{\mathrm{m}^{2}}{\mathrm{~s}}\right]$. It is therefore suggested that the start-up of the extraction is performed semi-batch, i.e. $(\mathrm{sc}) \mathrm{CO}_{2}$ is bubbled through the partially filled column. Within a few cycles of the $(\mathrm{sc}) \mathrm{CO}_{2}$ flow, the latex is swollen with $\mathrm{CO}_{2}$ and the actual continuous extraction process is started. At this point also the required operating temperatures and pressures of the equipment in every step are reached and the monomer extraction by $(\mathrm{sc}) \mathrm{CO}_{2}$ proceeds as described. Note that when the extraction column runs stationary, some extra column volume is needed to allow for swelling of the latex phase. To allow for a developed concentration profile in the polymer particles, i.e. Fo $\geq 0.1$, the contact time between the polymer particles and the $(\mathrm{sc}) \mathrm{CO}_{2}\left(\mathrm{t}_{\text {contact, }}\right)$ is $1 \mathrm{~s}$, calculated according to 
Equation 5 for $100 \mathrm{~nm}$ polymer particles and a diffusion coefficient $\left(\mathrm{D}_{\mathrm{CO}_{2}}^{\mathrm{P}}\right)$ of $\mathrm{CO}_{2}$ in $\mathrm{PS}$ of $10^{-15} \mathrm{~m}^{2} / \mathrm{s}$. 


\section{Equipment sizing and costs}

Table 7 summarizes the costs, characteristic dimensions and process parameters for the equipment as shown in Figure 11. The costs have been determined with the Aspen Process Economic Analyzer based on a production capacity of $50 \mathrm{kt}$ PS latex (45\% solids)/year. All equipment is made of stainless steel (316L) due to the corrosive properties of $\mathrm{H}_{2} \mathrm{O} / \mathrm{CO}_{2}$ mixtures and the relatively high viscosity of the latex and the latex swollen with $\mathrm{CO}_{2}$.

Table 7 Characteristic dimensions and purchased costs of equipment

\section{Capacity : 50 kt PS latex (45\% solids)/yr}

\begin{tabular}{l|c|c|c}
\hline & Extraction column & Separator including demister & Oxidation vessel \\
\hline \hline height $[\mathrm{m}]$ & 4.2 & 1 & 1 \\
\hline diameter $[\mathrm{m}]$ & 1.2 & 0.1 & 0.1 \\
\hline pressure $[\mathrm{bar}]$ & 100 & 60 & 60 \\
\hline temperature $\left[{ }^{\circ} \mathrm{C}\right]$ & 35 & 35 & 80 \\
\hline f.o.b. price $[\mathrm{k} €]$ & 614 & 45 & 45 \\
\hline material costs ${ }^{\#}[\mathrm{k} €]$ & 175 & 51 & 51 \\
\hline
\end{tabular}

\begin{tabular}{l|c|c}
\hline & Compressor & Pump \\
\hline \hline total power $[\mathrm{kW}]$ & 31 & 20 \\
\hline f.o.b. price $^{*}[\mathrm{k} €]$ & 390 & 20 \\
\hline material costs $^{\#}[\mathrm{k} €]$ & 40 & 12 \\
\hline
\end{tabular}

\begin{tabular}{l|c|c|c|c}
\hline & $\begin{array}{l}\text { Heat } \\
\text { exchanger (a) }\end{array}$ & $\begin{array}{l}\text { Heat } \\
\text { exchanger (d) }\end{array}$ & $\begin{array}{l}\text { Heat } \\
\text { exchanger (e) }\end{array}$ & $\begin{array}{l}\text { Heat } \\
\text { exchanger (h) }\end{array}$ \\
\hline \hline duty $[\mathrm{kW}]$ & 80.5 & 76.3 & 80.5 & 60.5 \\
\hline $\mathrm{A}\left[\mathrm{m}^{2}\right]$ & 4.5 & 3.2 & 2.1 & 1.5 \\
\hline f.o.b. price $[\mathrm{k} €]$ & 39 & 34 & 18 & 22 \\
\hline material costs $^{\#}[\mathrm{k} €]$ & 72 & 103 & 41 & 89 \\
\hline
\end{tabular}

"f.o.b. price stands for free on board price, i.e. the price of the equipment without installation costs

\# the material costs include piping, instrumentation, insulation, etc. 
The total investment costs include materials for installation, i.e. piping, instrumentation, insulation, etc., and labor costs. Table 8 generates the investment costs for the high

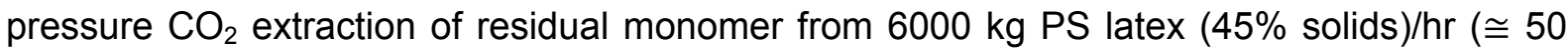
$\mathrm{kt} / \mathrm{yr})$.

Table 8 Investment costs for the reduction of the residual monomer concentration in PS latex from $10^{4} \mathrm{ppm}$ to $1 \mathrm{ppm}$ by extraction with $(\mathrm{sc}) \mathrm{CO}_{2}$ at 100 bar and $35{ }^{\circ} \mathrm{C}$ for a production capacity of $50 \mathrm{kt}$ PS latex ( $45 \%$ solids)/yr.

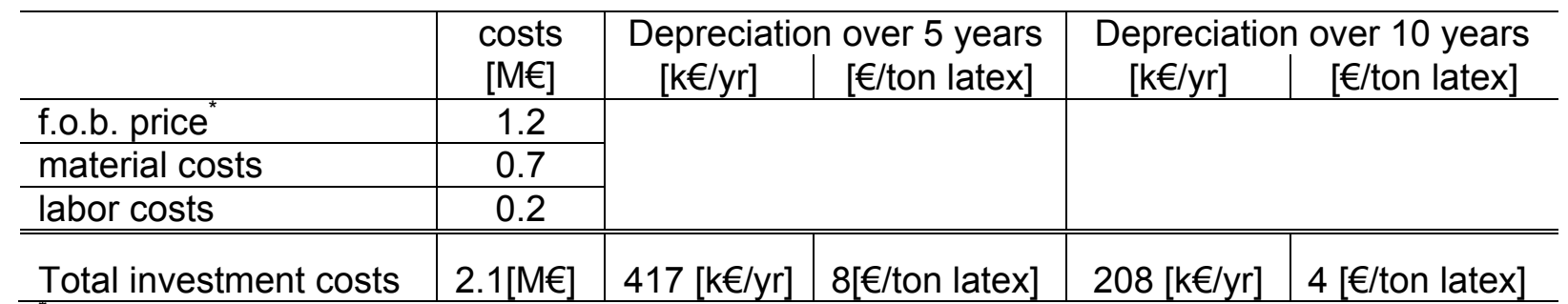

f.o.b. price stands for free on board price, i.e. the price of the equipment without installation costs

Table 9 collects the utility costs of the extraction process for a production capacity of $50 \mathrm{kt}$ PS latex ( $45 \%$ solids)/yr. The utility costs have been calculated based on price lists for steam and electricity from DACE (2009), the $\mathrm{CO}_{2}$ price was delivered by Linde Gas Benelux, the costs for the $\mathrm{Pt} / \mathrm{Al}_{2} \mathrm{O}_{3}$ catalyst has been estimated based on a price list from Evonik (2011). The costs for the $\mathrm{O}_{2}$ used in the oxidation step are not included due to the low consumption. The start up costs for $\mathrm{CO}_{2}$ have been included.

Table 9 Utility costs for the reduction of the residual monomer concentration in PS latex from $10^{4} \mathrm{ppm}$ to $1 \mathrm{ppm}$ by extraction with (sc) $\mathrm{CO}_{2} 100$ bar and $35^{\circ} \mathrm{C}$ for a production capacity of $50 \mathrm{kt} \mathrm{PS} \mathrm{latex} \mathrm{(45 \%} \mathrm{solids)/yr.} \mathrm{(see} \mathrm{Figure} \mathrm{11a)}$

\begin{tabular}{l|c|c|c|c}
\hline & unit price & amounts & Costs [k€/yr] & Costs [€/ton latex] \\
\hline electricity & $0.14 € / \mathrm{kWh}$ & $51 \mathrm{~kW}$ & 57.1 & 1.14 \\
\hline $\mathrm{CO}_{2}{ }^{*}$ & $20 € / \mathrm{ton}$ & $3.05 \mathrm{ton} / \mathrm{yr}$ & $61 * 10^{-3}$ & $1 * 10^{-3}$ \\
\cline { 3 - 5 } & & $15 * 10^{-3}$ ton $/ \mathrm{hr}$ & 2.4 & 0.05 \\
\hline steam $\left(1 \mathrm{bar}, 100{ }^{\circ} \mathrm{C}\right)$ & $30 € / \mathrm{ton}$ & $\begin{array}{c}128 * 10^{-3} \\
\text { ton/hr }\end{array}$ & 31 & 0.61 \\
\hline catalyst & $3500 € / \mathrm{kg}$ & $180 \mathrm{~kg} / \mathrm{yr}$ & 630 & 12.6 \\
\hline Total utility costs & & & 720 & 14.4 \\
\hline
\end{tabular}

The $\mathrm{CO}_{2}$ amount used in the extraction process is based on a production capacity of $50 \mathrm{kt}$ PS latex (45\% solids)/yr, without disruptions, i.e. cleaning of the equipment is performed once a year. In practice it is suggested the equipment is cleaned more often. The $\mathrm{CO}_{2}$ start up cost of $61 € /$ start up cycle then has to be included in the overall utility cost. Note, however, that the $\mathrm{CO}_{2}$ start up cost is negligible compared to the overall utility costs. 
In the first 5 years of the $(\mathrm{sc}) \mathrm{CO}_{2}$ based extraction process reducing residual monomer level in PS latex from $10^{4} \mathrm{ppm}$ to $1 \mathrm{ppm}$, the purification of the latex costs $22 € /$ ton latex. When the investment costs are recovered, the cost of the extraction of the residual monomer from the latex decreases to $14 € /$ ton latex.

Note that for a residual monomer reduction from $10^{4} \mathrm{ppm}$ to $100 \mathrm{ppm}$ or to $10 \mathrm{ppm}$, the costs for the purification of the latex are in the same range as for a reduction to $1 \mathrm{ppm}$. The higher the allowed residual monomer concentration in the latex phase after extraction, the less $\mathrm{CO}_{2}$ required to perform the extraction, resulting in lower residence times needed, i.e. shorter columns. The difference in $\mathrm{CO}_{2}$ needed to reduce the monomer concentration from $10^{4} \mathrm{ppm}$ to $100 \mathrm{ppm}$, to $10 \mathrm{ppm}$ or to $1 \mathrm{ppm}$, however, is small ${ }^{6}$, not affecting the total investment or utility costs.

\section{Steam stripping}

Englund (1981) gives an overview of several types of latex strippers. The author reports reducing the residual monomer level in latex with steam stripping is usually performed batch wise, due to its simplicity and ease of operation. A batch of latex is charged into a simple tank and steam is sparged through the latex at a certain flowrate, limited by foaming. Defoaming agents are often used to suppress foaming (Kelley et al., 1978). Batch strippers normally operate at $80-90 \%$ efficiency, but the amount of steam needed is higher than for continuous countercurrent stripping. Englund (1981) states that for batch stripping the frequency by which fresh steam bubbles contact the polymer particles is rate limiting. The author refers to several patents for a description of a continuous countercurrent stripper. Batch wise stripping as well as continuous countercurrent stripping for the reduction of residual monomer level in PS latex from $10^{4} \mathrm{ppm}$ to $100 \mathrm{ppm}$ are shortly discussed here.

\footnotetext{
${ }^{6}$ The amount of $\mathrm{CO}_{2}$ required for residual monomer reduction in PS latex from $10^{4} \mathrm{ppm}$ to 100,10 or $1 \mathrm{ppm}$, are 3000,3022 and $3024 \mathrm{~kg} / \mathrm{hr}$, respectively. The value of the $\mathrm{CO}_{2}$ stream indicated in the present work is somewhat higher to account for the $\mathrm{CO}_{2}$ that dissolves in the $\mathrm{H}_{2} \mathrm{O}$ phase.
} 


\section{Batch operation}

The steam flow rate required for stripping a batch of 30 ton ( $45 \%$ solids) PS latex in approximately 5 hours (i.e. $6000 \mathrm{~kg} / \mathrm{hr}$ ) to reduce residual monomer from $10^{4} \mathrm{ppm}$ to about 100 ppm has been calculated according to Equation 27 ( $r_{s}$ from B. Odedra, Synthomer, UK, personal communication) .

$\phi_{\text {steam }}=M_{\text {dry solids }} * r_{s}$

$r_{s}$ stands for the steam mass flow rate per kg dry solids.

Assuming that stripping is performed at $90 \%$ efficiency, the required steam flow rate is 1700 $\mathrm{kg} / \mathrm{hr}$, calculated with Equation 27. In 5 hours a total amount of $8500 \mathrm{~kg}$ steam is needed to reduce the residual monomer from $10^{4} \mathrm{ppm}$ to $100 \mathrm{ppm}$. The steam hold up in the latex is usually about $10-20 \%\left[\mathrm{~m}^{3}\right.$ steam bubbles $/ \mathrm{m}^{3}$ vessel) (Kantarci, 2005). The total liquid volume in the stripping vessel at $20 \%$ steam hold up becomes $38 \mathrm{~m}^{3}$. Englund (1981) emphasizes that the batch stripping vessel is usually considerably larger than the liquid load to allow for foaming. Assuming that the stripping vessel is enlarged by $50 \%$ of the liquid load, a tank of $57 \mathrm{~m}^{3}$ is needed. To operate the stripping vessel in the homogeneous bubble flow regime, the superficial gas velocity needs to be smaller than $0.05 \mathrm{~m} / \mathrm{s}$ (Kantarci, 2005). The superficial gas velocity is defined as the ratio of the volumetric flow rate and the crosssectional area of the vessel. The density of steam at $100{ }^{\circ} \mathrm{C}$ is $0.6 \mathrm{~kg} / \mathrm{m}^{3}$ (Perry, 1999). The tank diameter for a superficial gas velocity of $0.05 \mathrm{~m} / \mathrm{s}$ then is $2.2 \mathrm{~m}$; the height of the vessel is $14.5 \mathrm{~m}$.

The latex batch, before stripping is started, is at $15^{\circ} \mathrm{C}$ (i.e. latex from the polymerization reaction is kept in a storage vessel). The steam at $100{ }^{\circ} \mathrm{C}$ is partly used for heating the latex, i.e. $170 \mathrm{~kg} / \mathrm{hr}$ or $850 \mathrm{~kg}$ steam during 5 hours of stripping (see Appendix D). So $10 \%$ of the steam is used as heating source. As $10 \%$ is a significant part of the steam consumption, it is added in the total steam flow required for stripping the latex.

Figure 12 illustrates the simple batch stripping vessel. 


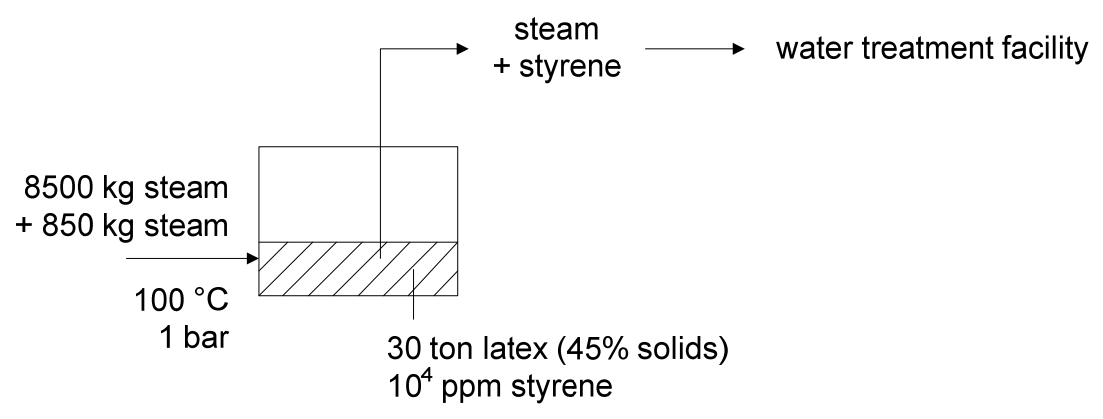

Figure 12 Batch stripping vessel

The steam containing the residual monomer has been chosen to be purified in a water treatment facility.

\section{Continuously operated countercurrent stripping unit}

Englund (1981) reports that the steam required to reduce residual monomer from $10^{4} \mathrm{ppm}$ to 100 ppm in a continuous countercurrent stripping vessel is less than the amount of steam used in the batch stripping vessel. Assuming a throughput of $6000 \mathrm{~kg} \mathrm{PS} \mathrm{latex/hr,} \mathrm{the}$ number of theoretical stages is determined with the stage-to-stage calculation according to Equation 2. Note that the monomer partition coefficient $\left(\mathrm{K}_{\mathrm{mon}}\right)$ for the distribution of styrene between the polymer particles and the steam decreases with decreasing residual monomer concentration in the polymer particles, i.e. $\mathrm{K}_{\text {mon }} \downarrow$ when $\mathrm{N}_{\mathrm{ts}} \uparrow$, where $\mathrm{N}_{\mathrm{ts}}$ stands for the number of theoretical stages. Table 10 shows the relation between the steam flow rate and the number of equilibrium stages.

Table 10 Required number of theoretical stages in function of the steam flow rate for a residual monomer reduction from $10^{4} \mathrm{ppm}$ to $100 \mathrm{ppm}$.

\begin{tabular}{c|c}
\hline steam flow rate $\left[\frac{\mathrm{kg}}{\mathrm{hr}}\right]$ & number of theoretical stages, $\mathrm{N}_{\mathrm{ts}}[-]$ \\
\hline \hline 1700 & 13 \\
\hline 1500 & 17 \\
\hline 1400 & 23 \\
\hline 1300 & 44 \\
\hline
\end{tabular}


Decreasing the steam flow rate increases the number of equilibrium stages needed to obtain the same reduction in residual monomer. A further decrease in steam flow rate results in unrealistic numbers of stages and is therefore not shown. Estimating the height equivalent to one theoretical stage to be $35 \mathrm{~cm}$ - the same value as has been found in the $\mathrm{CO}_{2}$ extraction process - the stripping vessel is $15.4 \mathrm{~m}$ high for a steam flow rate of $1300 \mathrm{~kg} / \mathrm{hr}$. For a superficial gas velocity of $0.05 \mathrm{~m} / \mathrm{s}$ (Kantarci, 2005) the column diameter has been calculated to be $2.2 \mathrm{~m}$.

Figure 12a shows the process flow diagram (PFD) for reduction of residual styrene by continuous countercurrent stripping with steam.

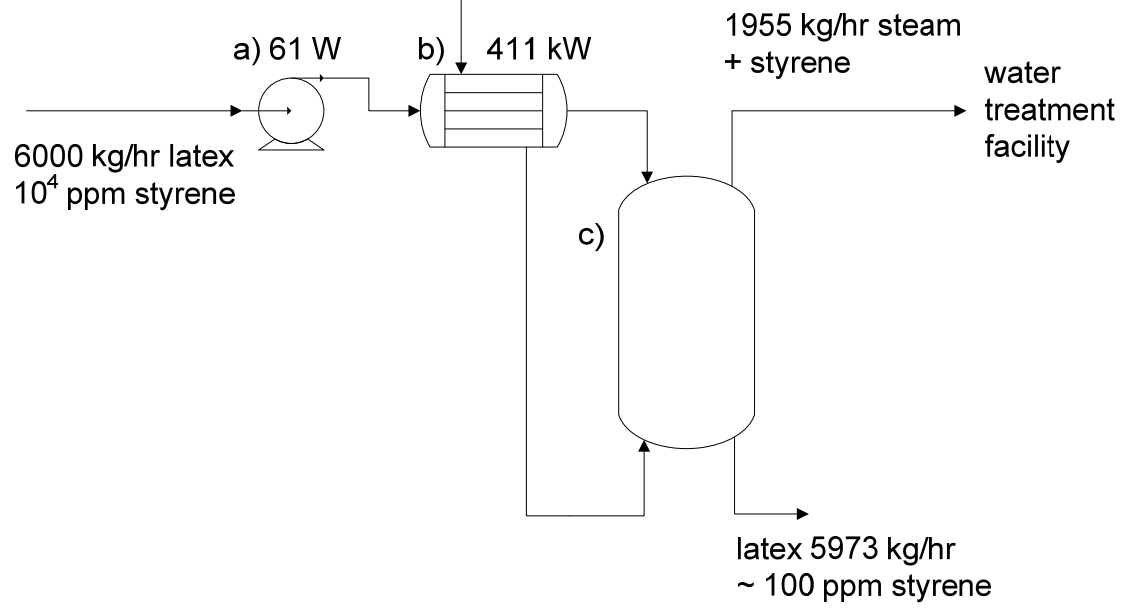

Figure 12a Process flow diagram (PFD) for reduction of residual styrene from $10^{4} \mathrm{ppm}$ to $100 \mathrm{ppm}$ by continuous countercurrent stripping with steam. a) pump, b) heat exchanger, c) stripper.

In the PFD a pump is included to pressurize the latex from 1 to $1.3 \mathrm{bar}$, to overcome the pressure drop inside the stripper. The latex flow is heated to the temperature of the stripping vessel, i.e. $100{ }^{\circ} \mathrm{C}$ by the steam flow entering the column for stripping the latex. Therefore somewhat more steam is required, i.e. $655 \mathrm{~kg}$ steam/hr for heating the latex (see Appendix 
D). Figure $12 \mathrm{~b}$ shows the complementary pressures and temperatures corresponding to the PFD, Figure 12a.

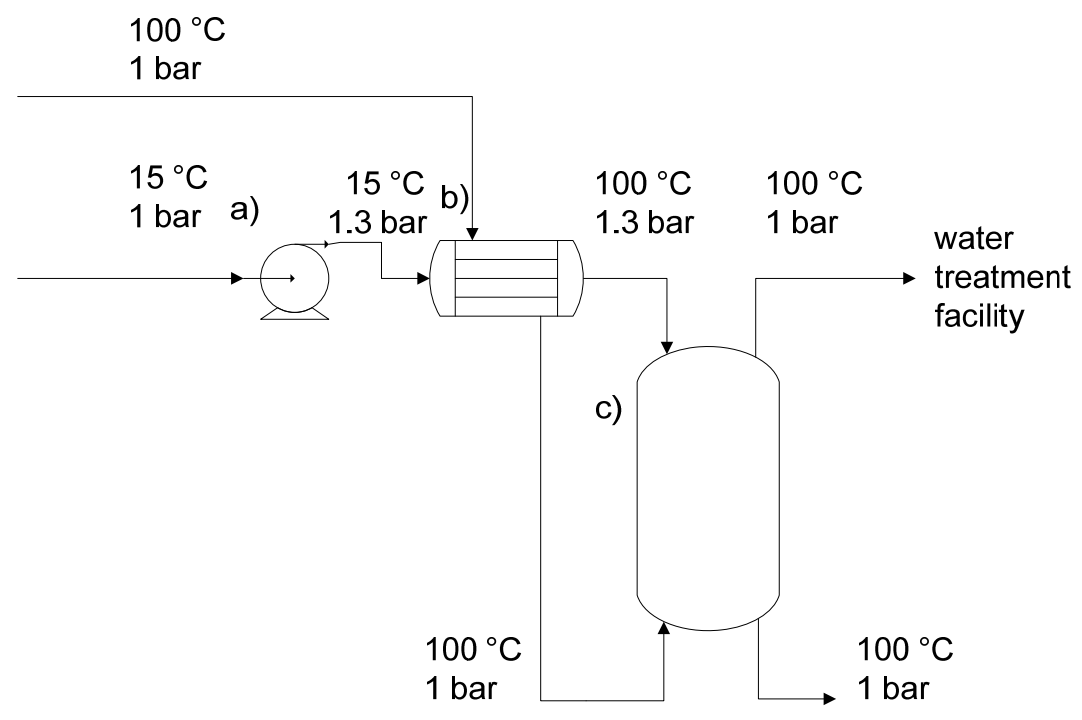

Figure 12b Temperature and pressure profiles for reduction of residual styrene from $10^{4} \mathrm{ppm}$ to about $100 \mathrm{ppm}$ by continuous countercurrent stripping with steam corresponding to the PFD shown in figure 12a. a) pump, b) heat exchanger, c) stripper.

Similar to batch steam stripping the steam containing styrene is led to a water treatment facility.

In the stripping vessels discussed above the residual monomer level in the latex was reduced from $10^{4} \mathrm{ppm}$ to $100 \mathrm{ppm}$. For some latex products a reduction to $60 \mathrm{ppm}$ residual monomer is possible (Araújo et al., 2002). Reduction to lower levels of residual monomer is hardly possible mainly due to thermodynamic (and to some extent transport) limitations. The monomer activity coefficient in the polymer particles and as a consequence the equilibrium monomer vapor pressure are very low at high conversions $(X>99 \%)$. Consequently, monomer partitioning between the polymer phase and the steam phase is very low towards the vapor phase, see Equation 28.

$\mathrm{y} * \mathrm{P}_{\text {total }}=\gamma_{\mathrm{m}} * \mathrm{x}_{\mathrm{m}} * \mathrm{P}_{\mathrm{m}}^{\mathrm{sat}}$ 
In contrast to the $\mathrm{CO}_{2}$ extraction process, where the polymer phase is swollen with $\mathrm{scCO}_{2}$ increasing the monomer activity coefficient in the polymer phase, the partition coefficient for steam stripping decreases with decreasing volume of the total amount of low molecular weight species in the polymer phase see Chapter 1, Figure 1. At low monomer volume fraction there is hardly any driving force for monomer anymore to diffuse to the vapor phase. Moreover, the molecular diffusion coefficient of monomer in the polymer phase is very low $\left(\mathrm{D}_{\mathrm{m}}^{\mathrm{P}}=10^{-15}\left[\frac{\mathrm{m}^{2}}{\mathrm{~s}}\right]\right)$, i.e. a high mass transfer resistance in the particle phase.

Table 11 shows steam flow rates as a function of the number of equilibrium stages for a monomer reduction from $10^{4}$ to $10 \mathrm{ppm}$ not taking into account the thermodynamic as well as the transport limitation discussed above.

Table 11 Required number of theoretical stages in function of the steam flow rate for a residual monomer reduction from $10^{4}$ to $10 \mathrm{ppm}$.

\begin{tabular}{c|c}
\hline steam flow rate $\left[\frac{\mathrm{kg}}{\mathrm{hr}}\right]$ & number of theoretical stages, $\mathrm{N}_{\mathrm{ts}}[-]$ \\
\hline \hline 15000 & 13 \\
\hline 12000 & 20 \\
\hline 11000 & 45 \\
\hline
\end{tabular}

\section{Equipment sizing and evaluation}

Table 12 summarizes the characteristic dimensions, process parameters and costs for the continuous steam stripping of residual monomer from PS latex, reducing the monomer level from $10^{4} \mathrm{ppm}$ to about $100 \mathrm{ppm}$. The costs have been determined with Aspen Process Economic Analyzer based on a production capacity of $50 \mathrm{kt}$ PS latex ( $45 \%$ solids)/yr. Stainless steel (316L) has been chosen as construction material. 
Table 12 Characteristic dimensions and purchased costs of equipment

\begin{tabular}{|c|c|c|c|c|c|}
\hline & column & & $\begin{array}{l}\text { heat } \\
\text { exchanger }\end{array}$ & & pump \\
\hline height [m] & 15.4 & duty [kW] & 411 & total power [kW] & 0.06 \\
\hline diameter [m] & 2.2 & $\mathrm{~A}\left[\mathrm{~m}^{2}\right]$ & 4.8 & f.o.b. price ${ }^{*}[k €]$ & 17 \\
\hline pressure [bar] & 1 & f.o.b.price ${ }^{*}[k €]$ & 10 & $\begin{array}{l}\text { material costs } \\
{[\mathrm{k} €]}\end{array}$ & 11 \\
\hline temperature $\left[{ }^{\circ} \mathrm{C}\right]$ & 100 & $\begin{array}{l}\text { material costs } \\
{[\mathrm{k} €]}\end{array}$ & 41 & & \\
\hline f.o.b.price $[k €]$ & 423 & & & & \\
\hline $\begin{array}{l}\text { material costs } \\
{[\mathrm{k} \in]}\end{array}$ & 177 & & & & \\
\hline
\end{tabular}

f.o.b. price stands for free on board price, i.e. the price of the equipment without installation costs

\# the material costs include piping, instrumentation, insulation, etc.

The total investment costs include materials for installation, i.e. piping, instrumentation, insulation, etc., as well as labor costs. Table 13 gives the investment costs for the reduction of residual monomer from $10^{4} \mathrm{ppm}$ to about $100 \mathrm{ppm}$ with continuous steam stripping of $6000 \mathrm{~kg}$ PS latex/hr.

Table 13 Investment costs for the reduction of the residual monomer concentration in PS latex from $10^{4} \mathrm{ppm}$ to $100 \mathrm{ppm}$ with $100^{\circ} \mathrm{C}$ steam for a production capacity of $50 \mathrm{kt}$ PS latex (45\% solids)/yr.

\begin{tabular}{|c|c|c|c|c|c|}
\hline & costs & \multicolumn{2}{|c|}{ Depreciation over 5 years } & \multicolumn{2}{|c|}{ Depreciation over 10 years } \\
\hline & {$[\mathrm{k} €]$} & {$[\mathrm{k} € / \mathrm{yr}]$} & [€/ton latex] & {$[\mathrm{k} € / \mathrm{yr}]$} & {$[€ /$ ton latex $]$} \\
\hline f.o.b. price ${ }^{*}$ & 450 & & & & \\
\hline material costs & 229 & & & & \\
\hline labor costs & 96 & & & & \\
\hline Total investment costs & $775[\mathrm{k} €]$ & $155[\mathrm{k} € / \mathrm{yr}]$ & $3[€ /$ ton latex $]$ & $77.5[\mathrm{k} € / \mathrm{yr}]$ & $2[€ /$ ton latex] \\
\hline
\end{tabular}

f.o.b. price stands for free on board price, i.e. the price of the equipment without installation costs

Table 14 collects the utility costs of the steam strip process for a production capacity of $50 \mathrm{kt}$ PS latex ( $45 \%$ solids)/yr. The utility costs have been calculated based on price lists for steam and electricity from DACE (2009). 
Table 14 Utility costs for the reduction of the residual monomer concentration in PS latex from $10^{4} \mathrm{ppm}$ to $100 \mathrm{ppm}$ with $100{ }^{\circ} \mathrm{C}$ steam for a production capacity of $50 \mathrm{kt}$ PS latex $(45 \%$ solids)/yr.

\begin{tabular}{l|c|c|c|c}
\hline & unit price & amount & Costs [k€/yr] & Costs [€/ton latex] \\
\hline electricity & $14 \mathrm{ct} / \mathrm{kWh}$ & $0.061 \mathrm{~kW}$ & 0.07 & 0.001 \\
\hline steam & $30 € / \mathrm{ton}$ & $1.96 \mathrm{ton} / \mathrm{hr}$ & 469 & 9.38 \\
\hline \hline Total utility costs & & & 718.9 & 9.39 \\
\hline
\end{tabular}

In the first 5 years of the steam stripping process reducing residual monomer level in PS latex (45\% solids) from $10^{4} \mathrm{ppm}$ to $100 \mathrm{ppm}$, the cost of purifying the latex by stripping the residual monomer content with steam is $12 € /$ ton latex. When the investment costs are recovered, the cost of the stripping process decreases to $9 € /$ ton latex.

Note that when a residual monomer reduction from $10^{4}$ to $10 \mathrm{ppm}$ would be thermodymically possible (within time limits), the utility costs of the steam consumption will tremendously increase as compared to the costs for a monomer reduction from $10^{4}$ to $100 \mathrm{ppm}$.. For a steam flow rate of $15000 \mathrm{~kg}$ steam/hr, the utility costs for steam are $75 € /$ ton latex.

\section{Extraction of residual monomer with $(\mathrm{sc}) \mathrm{CO}_{2}$ extraction in comparison to steam stripping}

The purification costs per ton latex for the steam stripping process and the (sc) $\mathrm{CO}_{2}$-based extraction process to reduce residual monomer in PS latex from $10^{4} \mathrm{ppm}$ to $100 \mathrm{ppm}$ for a production capacity of $50 \mathrm{kt}$ PS latex (45\% solids)/yr, are respectively 12 and $22 € /$ ton latex in the period the investment costs are recovered. After a depreciation time of 5 years, the price for steam stripping is $9 € /$ ton latex, whereas the cost for the $(\mathrm{sc}) \mathrm{CO}_{2}$ based extraction process is $14 € /$ ton latex. The $(\mathrm{sc}) \mathrm{CO}_{2}$-based extraction process reduces the residual monomer level to $1 \mathrm{ppm}$ for the same price as a reduction to $100 \mathrm{ppm}$ or to $10 \mathrm{ppm}$. Steam stripping, however, reduces the residual monomer level in the latex to only about $100 \mathrm{ppm}$ or somewhat lower, but certainly not to a level of $1 \mathrm{ppm}$. 


\section{Concluding remarks}

Extraction with $\mathrm{CO}_{2}$ to reduce residual monomer from $10^{4} \mathrm{ppm}$ to $1 \mathrm{ppm}$ in a countercurrent extraction process in a column has been designed. Latex has been chosen as the continuous phase in which $1 \mathrm{~mm} \mathrm{CO}$ bubbles are dispersed with a hold up of $20 \%$. The column is operated at 100 bar and $35^{\circ} \mathrm{C}$. The partition coefficient of monomer between the $\mathrm{CO}_{2}$-swollen polymer particles and the $\mathrm{CO}_{2}$ phase is a key parameter in the performance of the liquid-liquid extraction column in terms of the degree of residual monomer reduction. Due to the plasticizing effect of $(\mathrm{sc}) \mathrm{CO}_{2}$ the time constant for mass transport of monomer inside the polymer particles decreases tremendously compared to non swollen polymer particles. The mass transport mechanism is governed by the shuttle effect, due to the Brownian motion of the polymer particles from and to the $\mathrm{H}_{2} \mathrm{O} / \mathrm{CO}_{2}$ interface. A column volume of $4.75 \mathrm{~m}^{3}$ applies for a throughput of $6000 \mathrm{~kg}$ PS latex (45\% solids)/hr.

The extraction process reducing the residual monomer costs $22 € /$ ton latex for a production capacity of $50 \mathrm{kt} \mathrm{PS} \mathrm{latex} \mathrm{(45 \%} \mathrm{solids)/yr} \mathrm{(for} \mathrm{a} \mathrm{reduction} \mathrm{from} 10^{4}$ to $100 \mathrm{ppm}$, to $10 \mathrm{ppm}$ or to $1 \mathrm{ppm}$ ). Continuous steam stripping to reduce the residual monomer level in the latex from $10^{4} \mathrm{ppm}$ to $100 \mathrm{ppm}$ only costs $12 € /$ ton latex. The lowest residual monomer concentration in latex of $1 \mathrm{ppm}$ can certainly only be achieved by extraction with $(\mathrm{sc}) \mathrm{CO}_{2}$. 


\section{References}

M. Akgün, D. Emel, N. Baran, N. A. Akgün, S. Deniz, S. Dinçer, "Styrene-carbon dioxide phase equilibria at high pressures", J. Supercritical Fluids, 2004, 31, 27-32

H. E. A. van den Akker, "Liquid-liquid spray columns - Hydrodynamic stability and reduction of axial mixing", PhD Thesis, 1978, Eindhoven University of Technology, The Netherlands

H. E. A. van den Akker, R. F. Mudde, E. Stammers, "Fysische transportverschijnselen: 200 vraagstukken", 1997, $2^{\text {nd }}$ ed., Delft University Press, The Netherlands

E. Alper, B. Wichtendahl, W.-D. Deckwer, "Gas absorption mechanism in catalytic slurry reactors", Chem. Eng. Sci., 1980, 35, 217-222

S. Alsoy, J. L. Duda, "Supercritical devolatilization of polymers", AIChE, 1998, 44, 3, 582-590

P. H. H. Araújo, C. Sayer, J. G. R. Poço, R. Guidici, "Techniques for reducing residual monomer content in polymers: A review", Polym. Eng. Sci., 2002, 42, 7

A. A. C. M. Beenackers, W. P. M. Van Swaaij, "Mass transfer in gas-liquid slurry reactors, a review article", Chem. Eng. Sci. , 1993, 48, 18, 3109-3139

R. B. Bird, W. E. Stewart, E. N. Lightfoot, "Transport phenomena",2002, $2^{\text {nd }}$ edition, J. Wiley and sons Inc., New York

D. W. Brilman, W. P. M. van Swaaij, G. F. Versteeg, "A one-dimensional instationary heterogeneous mass transfer model for gas absorption in multiphase systems", Chem. Eng. and Process., 1998, 37, 471-488

C. H. Chon, K. D. Kihm, "Empirical correlation finding the role of temperature and particle size for nanofluid $\left(\mathrm{Al}_{2} \mathrm{O}_{3}\right)$ thermal conductivity enhancement", Appl. Phys. Lett., 2005, 87, 153107, 1-3

A. B. De Haan, H. Bosch, "Fundamentals of industrial separations", 2007, $2^{\text {nd }}$ edition, The Netherlands

Dutch Association of Cost Engineers (DACE), "Prijzenboekje”, $27^{\text {th }}$ ed., 2009

E. Dumont, H. Delmas, "Mass transfer enhancement of gas absorption in oil-in-water systems: a review", Chem. Eng. and Process., 2003, 42, 419-438

S. M. Englund, "Monomer removal from latex", Chem. Eng. Progr., 1981, 55-59; and references therein

J. van Deuren, T. Lloyd, S. Chhetry, R. Liou, J. Peck, Federal Remediation Technologies Roundtable, "Remediation technologies screening matrix and reference guide", $4^{\text {th }}$ ed., 2002, Washington

R. G. Gilbert, "Emulsion polymerization, A mechanistis approach", Academic Press, 1995

J. C. Godfrey, M. J. Slater (Eds.), "Liquid-liquid extraction equipment", 1994, J. Wiley and sons Inc., New York

C. Gourdon, G. Casamatta, G. Muratet, "Population balance based modeling of solvent extraction columns" in "Liquid-liquid extraction equipment", eds. J. C. Godfrey, M. J. Slater, 1994, J. Wiley and sons Inc., New York 
S. J. Jang, "Role of Brownian motion in the enhanced thermal conductivity of nanofluids", Appl. Phys. Lett., 2004, 84, 21, 4316

C. Joly-Vuillemin, C. Bellefon, "Solids effects on gas-liquid, Chem. Eng. Sci., 1999, 51, 10, 2149-2158

N. Kantarci, F. Borak, K. O. Ulgen, "Review: Bubble column reactors", Proc. Biochem., 2005, 40, 2263-2283

E. L. Kelley, R. W. Harrison, B. B. Harris, "Defoamers: their theory and application with regard to the paint industry", Polym., Paint and Colour J., 1978, 168, 734

M.F. Kemmere, M. Cleven, M. A. van Schilt, J. T. F. Keurentjes, "Process design for the removal of residual monomer from latex products using supercritical carbon dioxide", Chem. Eng. Sci., 2002, 57, 3929-3937

A. Kumar, S. Hartland, "Empirical prediction of operating variables" in "Liquid-liquid extraction equipment”, eds. J. C. Godfrey, M. J. Slater, 1994, J. Wiley and sons Inc., New York

A. Kumar, S. Hartland, "Unified correlations for the prediction of drop size in liquid-liquid extraction columns”, Ind. Eng. Chem. Res., 1996, 35, 2682-2695

W. L. McCabe, J. C. Smith, P. Harriott, "Unit operations of chemical engineering", 2001, $6^{\text {th }}$ edition, McGraww-Hill, New York

J. H. Perry, Chapter 15, "Liquid-liquid extraction equipment" in "Chemical Engineer's Handbook", 1999, McGraw-Hill, New York

J. F. Richardson, W. N. Zaki, "Sedimentation and fluidization: part 1", Trans. Inst. Chem. Eng. , 1954, 32, 35

C. A. Scholtens, J. Meuldijk, A. A. H. Drinkenburg, "Production of copolymers with a predefined intermolecular chemical composition distribution by emulsion polymerisation in a continuously operated reactor", Chem. Eng. Sci., 2001, 56, 955

W. D. Seider, J. D. Seader, D. R. Lewin, Widagdo, "Product and process design principles Synthesis, analysis and evaluation", 3th ed., 2010, John Wiley and sons Inc., USA

T. Seki, B. Alfons, "Catalytic oxidations in dense carbon dioxide", Chem. Rev., 2009, 109, 6, 2409-2454

M. J. Slater, "Rate coefficients in liquid-liquid extraction systems", in "Liquid-liquid extraction equipment", eds. J. C. Godfrey, M. J. Slater, 1994, J. Wiley and sons Inc. , New York

G. J. Suppes, M. McHugh, "Phase behavior of the carbon dioxide-styrene system", J. Chem. Eng. Dat., 1989, 34, 310-312

S. Torza, S. G. Mason, "Three-phase interactions in shear and electrical fields", J. Colloid Interface Sci., 1970, 33, 1, 67-83

H. Vinke, P. J. Hamersma, J. M. H. Fortuin, "Enhancement of the gas-absorption rate in agitated slurry reactors by gas-absorbing particles adhering to gas bubbles", Chem. Eng. Sci., 1993, 48, 12, 2197-2210

G. B. Wallis, "One-dimensional two-phase flow", 1969, McGraww-Hill, New York

J. Welty, C. E. Wicks, R. E. Wilson, "Fundamentals of momentum, heat, and mass transfer", 2001, $4^{\text {th }}$ ed., Wiley, Chichester 
J. A. Wesselingh, "The velocity of particles, drops and bubbles",Chem. Eng. Process., 1987, 21, 9-14

M. Xu, J. A. Finch, A. Uribe-Salas, "Maximum gas and bubble surface rates in flotation columns", Inter. J. Miner. Process., 1991, 32, (3/4), 233

S. X. Zhang, W. H. Ray, "Modeling and experimental studies of aqueous suspension polymerization processes. 3. Mass transfer and monomer solubility effects", Ind. Eng. Chem. Res., 1997, 36, 1310-1321

J. Zhang, L. Gao, X. Zhang, B. Zong, T. Jiang, B. Han, "Phase behaviors, density, and isothermal compressibility of styrene $+\mathrm{CO}_{2}$, ethylbenzene $+\mathrm{CO}_{2}$, and ethylbenzene + styrene+ $\mathrm{CO}_{2}$ systems", J. Chem. Eng. Data, 2005, 50, 1818-1822 


\section{Appendix A}

According to Newton's second law, three forces act on a (free falling) rigid sphere moving through a liquid (stationary momentum balance) (De Haan, 2007, McCabe, 2001):

$0=$ external force - buoyant force - drag force

$0=F_{G}-F_{B}-F_{D}$

The external force is in this case the gravitational force, the buoyant force is a force acting parallel with the external force but in opposite direction, and the drag force appears whenever there is relative motion between the spheres and the liquid.

$\mathrm{F}_{\mathrm{G}}-\mathrm{F}_{\mathrm{B}}=\mathrm{m}_{\text {sphere }} * \mathrm{~g}-\mathrm{V}_{\text {sphere }} * \rho_{\text {liquid }} * \mathrm{~g}=\frac{\pi * \mathrm{~d}_{\text {sphere }}^{3}}{6} *\left(\rho_{\text {sphere }}-\rho_{\text {liquid }}\right) * \mathrm{~g}$

The drag force is caused by the shear stresses at the surface of a particle moving through a viscous liquid as well as in eddies in a possible wake and is generally described with a drag coefficient, Equation A.3.

$\mathrm{F}_{\mathrm{D}}=\mathrm{C}_{\mathrm{D}} * \mathrm{~A}_{\perp} * \frac{1}{2} * \rho_{\text {liquid }} * \mathrm{v}^{2}=\mathrm{C}_{\mathrm{D}} *\left(\frac{\pi * \mathrm{~d}_{\text {sphere }}^{2}}{4}\right) * \frac{1}{2} * \rho_{\text {liquid }} * \mathrm{v}^{2}$

The force balance, Equation A.1, then becomes

$0=\frac{\pi * \mathrm{~d}_{\text {sphere }}^{3}}{6} *\left(\rho_{\text {sphere }}-\rho_{\text {liquid }}\right) * \mathrm{~g}-\mathrm{C}_{\mathrm{D}} *\left(\frac{\pi * \mathrm{~d}_{\text {sphere }}^{2}}{4}\right) *\left(\frac{1}{2} * \rho_{\text {liquid }} * \mathrm{v}^{2}\right)$

The terminal settling velocity is defined in Equation A.5:

$\mathrm{v}_{\infty}=\sqrt{\frac{4 *\left(\rho_{\text {sphere }}-\rho_{\text {liquid }}\right) * \mathrm{~g} * \mathrm{~d}_{\text {sphere }}}{3 * \rho_{\text {liquid }} * \mathrm{C}_{\mathrm{D}}}}$

For low Reynolds numbers, (i. e. $\mathrm{Re}=\frac{\mathrm{v}_{\mathrm{o}} * \mathrm{~d}_{\text {dispersed phase }} * \rho_{\text {continuous phase }}}{\mu_{\text {continuous phase }}}<1$, creep flow) the drag coefficient for rigid spheres is $C_{D}=\frac{24}{R e}$ (Bird et al., 2002).

The terminal rising (i.e. $=-$ settling velocity) velocity of a $\mathrm{CO}_{2}$ bubble then becomes:

$\mathrm{v}_{\infty}=\frac{-\left(\rho_{\mathrm{CO}_{2} \text { bubble }}-\rho_{\text {latex }}\right) * 9.81 * \mathrm{~d}_{\mathrm{CO}_{2}}^{2}}{\mu_{\text {latex }}}$

Table A.1 gives the physical constants of the dispersed $\mathrm{CO}_{2}$ phase as well as of the continuous latex phase used to calculate the terminal rising velocity $\left(\mathrm{v}_{\infty}\right)$ of a $\mathrm{CO}_{2}$ bubble. 
Table A.1 Physical constants of $\mathrm{CO}_{2}$ as well as of PS latex used to calculate the terminal rising velocity of $\mathrm{C} \mathrm{CO}_{2}$ bubble through the latex.

\begin{tabular}{l|l}
\hline$\rho_{\mathrm{CO}_{2} \text { bubble }}\left(35^{\circ} \mathrm{C}, 100 \mathrm{bar}\right)$ & $720 \mathrm{~kg} / \mathrm{m}^{3}$ \\
\hline$\rho_{\text {latex }}$ & $1020 \mathrm{~kg} / \mathrm{m}^{3}$ \\
\hline $\mathrm{d}_{\mathrm{CO}_{2} \text { bubble }}$ & $10^{-3} \mathrm{~m}$ \\
\hline$\mu_{\text {latex }}$ & $64 \mathrm{mPas}$ \\
\hline
\end{tabular}

The terminal rising velocity becomes:

$\mathrm{v}_{\infty}=3 * 10^{-3} \frac{\mathrm{m}}{\mathrm{s}}$

Note that the Reynolds number is indeed $<1$, see Equation A.8.

$\mathrm{Re}=\frac{\mathrm{v}_{\infty} * \mathrm{~d}_{\text {dispersed phase }} * \rho_{\text {continuous phase }}}{\mu_{\text {continuous phase }}}=\frac{3 * 10^{-3} * 10^{-3} * 1020}{64 * 10^{-3}} \cong 0.05$

The rising velocity of the bubble swarm in the column according to Equation A.9 is:

$\mathrm{v}_{\mathrm{s}}=\mathrm{v}_{\infty} *\left(1-\varepsilon_{\mathrm{d}}\right)^{\mathrm{n}-1}$

where $\mathrm{n}$ depends on $\mathrm{Re}$, see Equations 21-24, and has a value of 4.65 fo the Reynolds number of 0.05 , see Equation A.8. For a $\mathrm{CO}_{2}$ hold up of $20 \%\left[\mathrm{~m}^{3} \mathrm{CO}_{2}\right.$ bubbles $/ \mathrm{m}^{3}$ column $]$ in the column, $v_{s}$ becomes:

$\mathrm{v}_{\mathrm{S}}=3 * 10^{-3} *(1-0.2)^{4.65-1} \cong 1 * 10^{-3} \frac{\mathrm{m}}{\mathrm{s}}$ 


\section{Appendix B}

In this appendix the process flow diagram (PFD), Figures $11 \mathrm{a}$ and $11 \mathrm{~b}$, is explained into detail. The annotation used in this section corresponds to that in the respective figures.

\section{Extraction column (c)}

The extractor, $1.2 \mathrm{~m}$ in diameter and $4.2 \mathrm{~m}$ high, is operated at 100 bar and $35{ }^{\circ} \mathrm{C}$. The overall heat balance over the extraction column is expressed in Equation B.1:

$\phi_{\mathrm{q}}($ column $)=\phi_{\mathrm{m}, \mathrm{CO}_{2}} * \mathrm{C}_{\mathrm{p}, \mathrm{CO}_{2}} * \Delta \mathrm{T}+\phi_{\mathrm{m}, \text { latex }} * \mathrm{C}_{\mathrm{p}, \text { latex }} * \Delta \mathrm{T}+\phi_{\mathrm{q}}$

where $\phi_{m, i}, C_{p, i}$ and $\phi_{q}$ stand for the mass flow rate of phase $\mathrm{i}$, for the specific heat of phase $\mathrm{i}$ and for the heat flow lost to the surroundings. To prevent temperature gradients inside the column due to cooling by the surrounding air, it is insulated with e.g. mineral wool. The air temperature is assumed to be $15{ }^{\circ} \mathrm{C}$. The heat flow rate from the extraction column to the surroundings follows from Equation B.2. Note that the resistances against heat transfer from the liquid in the column to the wall of the column as well as from the wall to the surrounding air have been neglected.

$\phi_{\mathrm{q}}=\mathrm{U} * \mathrm{~A} * \Delta \mathrm{T}$

where $U$ and $A$ stand for the overall heat transfer coefficient and the column area respectively. Mineral wool has a thermal conductivity coefficient $(\lambda)$ of $0.0523\left[\frac{\mathrm{w}}{\mathrm{m}}{ }^{\circ} \mathrm{C}\right]$ (Perry, 1999). An estimation of the overall heat transfer coefficient for mineral wool follows from Equation B.3,

$\mathrm{U}=\frac{\lambda}{\delta_{\text {insulation }}}\left[\frac{\mathrm{W}}{\mathrm{m}^{2}{ }^{\circ} \mathrm{C}}\right]=1\left[\frac{\mathrm{W}}{\mathrm{m}^{2}{ }^{\circ} \mathrm{C}}\right] \quad$ for an insulation thickness of $5 \mathrm{~cm}$

The resulting heat flow rate from the liquid in the column to the surrounding air then becomes:

$$
\phi_{\mathrm{q}}=1 *\left(\frac{\pi * 4.2 * 1.2^{2}}{4}\right) *(35-15)[\mathrm{kW}] \cong 0.32[\mathrm{~kW}]
$$

Table B. 1 gives the physical constants of latex as well as of $\mathrm{CO}_{2}$ at 100 bar at $35^{\circ} \mathrm{C}$. 
Table B.1 Flow rates and physical constants of latex as well as of $\mathrm{CO}_{2}$ at 100 bar at $35^{\circ} \mathrm{C}$

\begin{tabular}{l|c|c|c|c}
\hline & \multicolumn{2}{|c|}{$\phi_{\mathrm{m}}$} & $\rho$ & $\begin{array}{c}\mathrm{C}_{\mathrm{p}} \\
\mathrm{kJ} / \mathrm{kg}{ }^{\circ} \mathrm{C}\end{array}$ \\
\hline latex & 6000 & 1.67 & 1020 & 2.9 \\
\hline $\mathrm{CO}_{2}$ & 3050 & 0.85 & 720 & 4.7 \\
\hline
\end{tabular}

As the mass flow rate as well as the specific heat ${ }^{7}$ inside the column is known, the temperature loss to the environment easily follows from Equation B.5:

$\Delta \mathrm{T}=\frac{\phi_{\mathrm{q}}}{\phi_{\mathrm{CO}_{2}+\text { latex }}{ }^{*} \mathrm{C}_{\mathrm{p}, \mathrm{CO}_{2}+\text { latex }}}=\frac{0.32}{2.52 * 3.5}{ }^{\circ} \mathrm{C} \cong 0.04{ }^{\circ} \mathrm{C}$

So heat loss from the extraction unit to the environment is negligible.

\section{Pump (b)}

$6000 \mathrm{~kg}$ PS latex/hr is delivered at $15^{\circ} \mathrm{C}$ at 1 bar. Before entering the extraction column the latex has to be pressurized to 100 bar and heated to $35^{\circ} \mathrm{C}$. For pressurizing the latex from 1 bar to 100 bar, a plunger pump has been chosen. The shaft work required for pressurizing the latex has been calculated with Equation B.6:

$\phi_{\mathrm{w}, \text { shaft }}($ pump $)=\phi_{\mathrm{m}, \text { latex }} * \frac{\mathrm{P}_{2}-\mathrm{P}_{1}}{\rho_{\text {latex }}}$

where $\phi_{\mathrm{m}, \text { latex }}$ and $\rho_{\text {latex }}$ stand for the mass flow and density of latex, see Table B.1. The shaft work of the pump then becomes:

$\phi_{\mathrm{w}, \text { shaft }}($ pump $)=1.67 * \frac{100-1}{1020} * 10^{5}[\mathrm{~W}]=16.2[\mathrm{~kW}]$

Pressurizing heated latex increases the chance on fouling inside the pump. Regularly cleaning has to be taken into account.

It is assumed the pump works at $80 \%$ of its efficiency, so

$\phi_{\mathrm{w}, \text { tot }}($ pump $)=\frac{\phi_{\mathrm{w}, \text { shaft }}(\mathrm{pump})}{0.8} \cong 20.3 \mathrm{~kW}$

\footnotetext{
${ }^{7}$ Inside the extraction column the total mass flow rate is $9050 \mathrm{~kg} / \mathrm{hr}(=2.52 \mathrm{~kg} / \mathrm{s})$ being $34 \% \mathrm{CO}_{2}$, with a specific heat of $4.7\left[\mathrm{~kJ} / \mathrm{kg}^{\circ} \mathrm{C}\right]$ (deducted from Mollier diagram) and $66 \%$ latex, with a specific heat of $2.9\left[\mathrm{~kJ} / \mathrm{kg}{ }^{\circ} \mathrm{C}\right]$ (Perry, 1999). Then the specific heat of the $\mathrm{CO}_{2} /$ latex mixture is $3.5\left[\mathrm{~kJ} / \mathrm{kg}^{\circ} \mathrm{C}\right]$.
} 
$20 \%$ of the work the pump delivers is dissipated in heat. Assuming that all the heat dissipated is transferred to the latex, a temperature rise of the latex follows from Equation B.9.

$\Delta \mathrm{T}=\frac{0.2 * \phi_{\mathrm{w}, \text { tot }}(\mathrm{pump})}{\phi_{\mathrm{m}, \text { latex }} * \mathrm{C}_{\mathrm{p}, \text { latex }}} \cong 0.8^{\circ} \mathrm{C}$

The latex still has to be heated by $19.2^{\circ} \mathrm{C}$, see heat exchanger (a).

\section{Compressor (j)}

The energy balance for the adiabatically operating compressor is expressed in Equation B.10.

$\phi_{\mathrm{w}, \text { shaft }}($ compressor $)=\phi_{\mathrm{m}, \mathrm{CO}_{2}} * \Delta\left(\mathrm{u}+\frac{\mathrm{P}}{\rho}\right)=\phi_{\mathrm{m}, \mathrm{CO}_{2}} * \Delta \mathrm{h}$

$3050 \mathrm{~kg} \mathrm{CO} / \mathrm{hr}$ enters the compressor at $80{ }^{\circ} \mathrm{C}$ and 60 bar. The extraction conditions have been chosen at $35{ }^{\circ} \mathrm{C}$ and 100 bar, so $\mathrm{CO}_{2}$ needs to be compressed and cooled. According to the Mollier diagram, Appendix $\mathrm{C}$, isentropic compression (i.e. $\mathrm{s}=1.25 \mathrm{kcal} /{ }^{\circ} \mathrm{C}$ ) from 60 to 100 bar requires $29.3 \mathrm{~kJ} / \mathrm{kg}$ (i.e. $7 \mathrm{kcal} / \mathrm{kg}$ ).

$\phi_{\mathrm{w}, \text { shaft }}($ compressor $)=0.85 * 29.3[\mathrm{~kW}] \cong 25[\mathrm{~kW}]$

At $80 \%$ efficiency, the total power the compressor needs is

$\phi_{\mathrm{W}, \text { tot }}($ compressor $)=\frac{25}{0.8}[\mathrm{~kW}] \cong 31[\mathrm{~kW}]$

At the same time due to the isentropic compression the temperature of the $\mathrm{CO}_{2}$ rises to 120 ${ }^{\circ} \mathrm{C}$. Isobaric cooling of the $\mathrm{CO}_{2}$ flow from $120{ }^{\circ} \mathrm{C}$ to $35{ }^{\circ} \mathrm{C}$, generates $256 \mathrm{~kJ} / \mathrm{kg}$ (i.e. 61 $\mathrm{kcal} / \mathrm{kg}$ ), which can be used to heat the latex and $\mathrm{CO}_{2}$ flow at other stages in the process, see PFD, Figure 11, heat exchanger $a, d$ and $h$.

\section{Separation vessel $(g)$}

To separate (to some extent) styrene from the $\mathrm{CO}_{2}$ leaving the extraction column, operating conditions of the separation vessel have been chosen at $35^{\circ} \mathrm{C}$ and 60 bar. The gas flow 
superficial velocity $\left(v_{s}\right)$ has been taken at $0.5 \mathrm{~m} / \mathrm{s}$. Table B.2 gives the physical constants used in the calculation of the required vessel surface area.

Table B.2 Flow rates and physical constants used for the calculation of the vessel area perpendicular to flow at $35^{\circ} \mathrm{C}$ at 60 bar.

\begin{tabular}{l|l|l}
\hline$\phi_{\mathrm{m}, \mathrm{CO}_{2}}+$ styrene & $3074 \mathrm{~kg} / \mathrm{hr}$ & $0.85 \mathrm{~kg} / \mathrm{s}$ \\
\hline$\rho_{\mathrm{CO}_{2}}$ & $300 \mathrm{~kg} / \mathrm{m}^{3}$ & \\
\hline $\mathrm{v}_{\mathrm{S}}$ & $0.5 \mathrm{~m} / \mathrm{s}$ \\
\hline
\end{tabular}

The vessel area perpendicular to flow $\left(A_{\text {separator, } \perp}\right)$ has been calculated with Equation B.13.

$\mathrm{A}_{\text {separator, } \perp}=\frac{\phi_{\mathrm{v}, \mathrm{CO}_{2}+\text { stryrene }}}{\mathrm{v}_{\mathrm{s}}}$

where $\phi_{\mathrm{v}, \mathrm{CO}_{2}+\text { stryrene }}$ stands for the volume flow of the mixture $\mathrm{CO}_{2} /$ styrene.

$\mathrm{A}_{\text {separator }}=\frac{0.85}{300} * \frac{1}{0.5}\left[\mathrm{~m}^{2}\right] \cong 60\left[\mathrm{~cm}^{2}\right]$

Including a demister, the dimensions of the separation vessel have been estimated at $0.1 \mathrm{~m}$ in diameter and $1 \mathrm{~m}$ in height.

\section{Oxidation vessel}

In a second separation step the styrene ( $40 \mathrm{ppm}$ on weight base) is suggested to be removed from the gaseous $\mathrm{CO}_{2}$ flow by means of catalytic oxidation with pure oxygen (stoechiometric amount). The styrene/ $\mathrm{CO}_{2}$ mixture is led over a fixed bed of Platinum (Pt) catalyst on a silica or alumina support in a nitrogen free environment. The styrene is completely converted into $\mathrm{CO}_{2}$ and $\mathrm{H}_{2} \mathrm{O}$. The oxidation is exothermic but requires some heat to start. The operating conditions in the oxidation step have been chosen at 60 bar and 80 ${ }^{\circ} \mathrm{C}$. The amount of catalyst needed has been estimated at $180 \mathrm{~kg}$ when the $\mathrm{M}_{\text {cat }} / \phi_{\text {styrene }}+\mathrm{O}_{2}$ ratio is approximately $1 \mathrm{~g} / \mathrm{molhr}^{-1}$ (for a production capacity of $50 \mathrm{kt} \mathrm{PS} \mathrm{latex} \mathrm{(45 \%} \mathrm{solids)/yr).}$ For more information concerning the catalytic oxidation step the reader is referred to specialized literature (Seki, 2009, Evonik Industries, 2011). 
Table B.3 shows the properties of the components in the oxidation vessel. The gas residence time $\left(\tau_{\mathrm{CO}_{2}}+\right.$ styrene $\left.+\mathrm{O}_{2}\right)$ in the oxidation vessel is assumed to be $1 \mathrm{~s}$ (van Deuren, 2002).

Table B.3 Flow rates and physical properties of the $\mathrm{CO}_{2} /$ styrene $/ \mathrm{O}_{2}$ mixture in the oxidation vessel at 60 bar at $80{ }^{\circ} \mathrm{C}$.

\begin{tabular}{l|l|l}
\hline$\phi_{\mathrm{m}, \mathrm{CO}_{2}+\text { styrene }+\mathrm{O}_{2}}$ & $3035 \mathrm{~kg} / \mathrm{hr}$ & $0.84 \mathrm{~kg} / \mathrm{s}$ \\
\hline$\rho_{\mathrm{CO}_{2}}$ & $110 \mathrm{~kg} / \mathrm{m}^{3}$ & \\
\hline$\tau_{\mathrm{CO}_{2}+\text { styrene }+\mathrm{O}_{2}}$ & $1 \mathrm{~s}$ \\
\hline
\end{tabular}

The oxidation vessel volume has been calculated according to Equation B.15.

$\mathrm{V}_{\text {oxidation vessel }}=\phi_{\mathrm{V}, \mathrm{CO}_{2}+\text { styrene }+\mathrm{O}_{2}} * \tau_{\mathrm{CO}_{2}+\text { styrene }+\mathrm{O}_{2}}$

$\mathrm{V}_{\text {oxidation vessel }}=\frac{0.84}{110} * 1\left[\mathrm{~m}^{3}\right] \cong 7.6 * 10^{-3}\left[\mathrm{~m}^{3}\right]$

Including some extra space inside the vessel to prevent gas build up at any time, the dimensions of the oxidation vessel have been estimated at $0.1 \mathrm{~m}$ in diameter and $1 \mathrm{~m}$ height.

\section{Heat exchangers}

At three different stages in the PFD heat exchangers are necessary:

- Heating $6000 \mathrm{~kg} \mathrm{PS}$ latex/hr from $15^{\circ} \mathrm{C}$ to $35^{\circ} \mathrm{C}$, see Figure $11 \mathrm{~b}$, heat exchanger a

- Increasing temperature of $3077 \mathrm{~kg}$ (styrene/ $/ \mathrm{CO}_{2}$ ) mixture/hr from $35^{\circ} \mathrm{C}$ to $72{ }^{\circ} \mathrm{C}$, see Figure $11 \mathrm{~b}$, heat exchangers $(\mathrm{d})$ and $(\mathrm{e})$

- Heating up $3045 \mathrm{~kg}$ (styrene/CO $\mathrm{CO}_{2}$ ) mixture/hr from $35{ }^{\circ} \mathrm{C}$ to $80^{\circ} \mathrm{C}$ for the catalytic oxidation, see Figure 11b, heat exchanger (i)

The power each heat exchanger need is calculated as follows:

- Heating $6000 \mathrm{~kg} \mathrm{PS}$ latex/hr from $15{ }^{\circ} \mathrm{C}$ to $35^{\circ} \mathrm{C}$ requires a heat flow of (see Table B. 1 for the physical constants of latex)

$$
\phi_{\mathrm{q}, \text { latex }}=\phi_{\mathrm{m}, \text { latex }} * \mathrm{C}_{\mathrm{p}, \text { latex }} * \Delta \mathrm{T}
$$




$$
\phi_{\mathrm{q}, \text { latex }}=1.67 * 2.9 * 20[\mathrm{~W}] \cong 96.7 \mathrm{~kW}
$$

Pressurizing the latex flow increases its temperature by $0.8{ }^{\circ} \mathrm{C}$. Dimensioning the heat exchanger, only $80.5 \mathrm{~kW}$ is required to increase the temperature from $15^{\circ} \mathrm{C}$ to $34.2{ }^{\circ} \mathrm{C}$.

- According to the Mollier diagram an isobaric temperature increase of the styrene/ $\mathrm{CO}_{2}$ mixture (see Table B.2 for the physical constants) from $35{ }^{\circ} \mathrm{C}$ to $72{ }^{\circ} \mathrm{C}$ at 100 bar corresponds to $176 \mathrm{~kJ} / \mathrm{kg}$ (i.e. $42 \mathrm{kcal} / \mathrm{kg}$ ).

$$
\begin{aligned}
& \phi_{\mathrm{q}, \mathrm{CO}_{2}}(\text { separator })=\phi_{\mathrm{m}, \mathrm{CO}_{2}} * \Delta \mathrm{h} \\
& \phi_{\mathrm{q}, \mathrm{CO}_{2}}(\text { separator })=0.85 * 176[\mathrm{~kW}] \cong 150[\mathrm{~kW}]
\end{aligned}
$$

- Increasing the temperature of the styrene $/ \mathrm{CO}_{2}$ mixture (see Table B.3 for the physical constants) from $35^{\circ} \mathrm{C}$ to $80^{\circ} \mathrm{C}$ at 60 bar requires $71 \mathrm{~kJ} / \mathrm{kg}$ (i.e. $17 \mathrm{kcal} / \mathrm{kg}$ ).

$$
\phi_{\mathrm{q}, \mathrm{CO}_{2}}(\text { oxidation vessel })=0.84 * 71[\mathrm{~kW}] \cong 60.5[\mathrm{~kW}]
$$

As mentioned in the section 3 , the $\mathrm{CO}_{2}$ after compression provides a latent heat loss of 256 $\mathrm{kJ} / \mathrm{kg}$ (i.e. $61 \mathrm{kcal} / \mathrm{kg}$ ) upon decreasing the temperature from $120{ }^{\circ} \mathrm{C}$ to $35^{\circ} \mathrm{C}$ at 100 bar. In the best scenario the $\mathrm{CO}_{2}$ latent heat loss is used to heat other streams in the following order

- At the catalytic oxidation $(71 \mathrm{~kJ} / \mathrm{kg}=17 \mathrm{kcal} / \mathrm{kg})$, heat exchanger $(\mathrm{h})$ The respective temperatures of the heated and cooled $\mathrm{CO}_{2}$ flow: $35^{\circ} \mathrm{C} \rightarrow 80{ }^{\circ} \mathrm{C}$ and $120^{\circ} \mathrm{C} \rightarrow 78^{\circ} \mathrm{C}$

- $\quad$ At the separator $(\sim 96.4=23 \mathrm{kcal} / \mathrm{kg})$, heat exchanger $(\mathrm{d})$ The respective temperatures of the heated and cooled $\mathrm{CO}_{2}$ flow: $35{ }^{\circ} \mathrm{C} \rightarrow 48{ }^{\circ} \mathrm{C}$ and $78^{\circ} \mathrm{C} \rightarrow 50^{\circ} \mathrm{C}$, heat exchanger (d)

- Before the pump pressurizing the latex flow $(\sim 88 \mathrm{~kJ} / \mathrm{kg}=21 \mathrm{kcal} / \mathrm{kg})$, heat exchanger (a)

The respective temperatures of the heated latex and cooled $\mathrm{CO}_{2}$ flow: $15^{\circ} \mathrm{C} \rightarrow 34.2$ ${ }^{\circ} \mathrm{C}$ and $50^{\circ} \mathrm{C} \rightarrow 35^{\circ} \mathrm{C}$

At the separator one extra heat exchanger is required heating the $\mathrm{CO}_{2}$ flow from $48{ }^{\circ} \mathrm{C}$ to 72 ${ }^{\circ} \mathrm{C}$. Steam at $100{ }^{\circ} \mathrm{C}$ and 1 bar is used for this purpose. The amount of steam required has 
been calculated dividing the required power by the heat of vaporization of steam (Perry, 1999) at $100{ }^{\circ} \mathrm{C}$, Equation B.22.

$\phi_{\text {steam }}=\frac{\phi_{\mathrm{q}, \mathrm{e}}(\text { heat exchanger } \mathrm{e})}{\Delta_{\mathrm{vap}} \mathrm{h}}\left[\frac{\mathrm{kg}}{\mathrm{hr}}\right]=\frac{80.5 * 3600}{2257.8}\left[\frac{\mathrm{kg}}{\mathrm{hr}}\right]=128\left[\frac{\mathrm{kg}}{\mathrm{hr}}\right]$

Dimensioning the different heat exchangers described above, has been performed according to Equation B.23.

$\phi_{\mathrm{q}, \mathrm{i}}($ heat exchanger $\mathrm{i})=\mathrm{U} * \mathrm{~A} * \Delta \mathrm{T}_{\mathrm{ln}}$

where $\Delta T_{\text {ln }}$ stands for the logarithmic mean temperature difference between the heated and cooled stream.

Table B.4 gives the physical properties as well as the resulting heat transfer area of the different heat exchangers (h), at the oxidation vessel, (d) at the separator, (a) to heat the latex, (e) at the separator.

Table B.4 Physical properties as well as the resulting heat transfer area for the heat exchangers (h), at the oxidation vessel, (d) at the separator, (a) to heat up the latex, (e) at the separator

\begin{tabular}{c|c|c|c|c}
\hline heat exchanger $\mathrm{i}$ & $\phi_{\mathrm{q}, \mathrm{i}}[\mathrm{kW}]$ & $\mathrm{U}\left[\frac{\mathrm{w}}{\mathrm{m}^{2}{ }^{\circ} \mathrm{C}}\right]^{8}$ & $\Delta \mathrm{T}_{\mathrm{ln}}\left[{ }^{\circ} \mathrm{C}\right]$ & $\mathrm{A}_{\mathrm{i}}\left[\mathrm{m}^{2}\right]$ \\
\hline $\mathrm{h}$ & 60.5 & 1000 & 41.5 & 1.5 \\
\hline $\mathrm{d}$ & 76.3 & 1000 & 24 & 3.2 \\
\hline $\mathrm{a}$ & 80.5 & 1000 & 17.8 & 4.5 \\
\hline $\mathrm{e}$ & 80.5 & 1000 & 38.8 & 2.1 \\
\hline
\end{tabular}

\section{Pressure reducer (f)}

Before the styrene/ $\mathrm{CO}_{2}$ mixture enters the separator, its pressure is expanded from 100 bar to 60 bar. This process generates $21 \mathrm{~kJ} / \mathrm{kg}$ (i.e. $5 \mathrm{kcal} / \mathrm{kg}$ ) that is lost, see Equation B.24.

$\phi_{\mathrm{q}, \mathrm{CO}_{2}}($ pressure reducer $)=0.85 * 21[\mathrm{~kW}] \cong 18[\mathrm{~kW}]$

\footnotetext{
${ }^{8}$ The overall heat transfer coefficient of $\mathrm{CO}_{2}$ is estimated at $1000\left[\frac{\mathrm{w}}{\mathrm{m}^{2}{ }^{\circ} \mathrm{C}}\right]$, the same value as for $\mathrm{H}_{2} \mathrm{O}(\mathrm{Perry}, 1999)$ as the density of both components are very similar.
} 


\section{Appendix C}

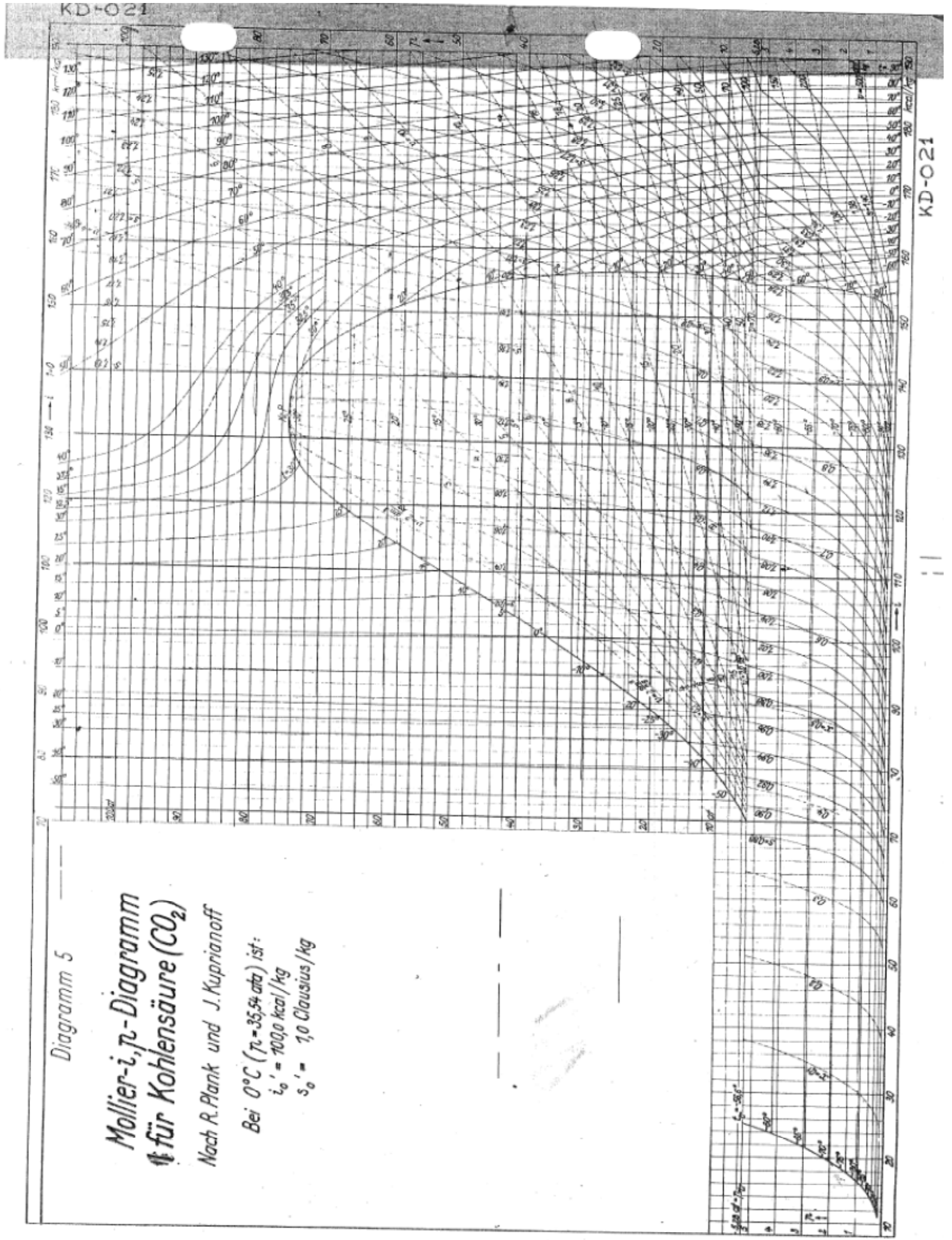




\section{Appendix D}

In a batch stripping vessel, steam at $100{ }^{\circ} \mathrm{C}$ is directly contacted with the cold latex of $15{ }^{\circ} \mathrm{C}$. The steam therefore condenses at $100{ }^{\circ} \mathrm{C}$. The amount of steam needed to heat the latex has been calculated with Equation D.1. Table D.1 shows the physical properties of latex.

Table D.1 Physical properties of latex

\begin{tabular}{l|c|c|c|c}
\hline & \multicolumn{2}{|c|}{$\phi_{\mathrm{m}}$} & $\rho$ & $\mathrm{C}_{\mathrm{p}}$ \\
& $\mathrm{kg} / \mathrm{hr}$ & $\mathrm{kg} / \mathrm{s}$ & $\mathrm{kg} / \mathrm{m}^{3}$ & $\mathrm{~kJ} / \mathrm{kg}^{\circ} \mathrm{C}$ \\
\hline latex & 6000 & 1.67 & 1020 & 2.9 \\
\hline
\end{tabular}

$$
\begin{aligned}
& \phi_{\text {steam }}=\frac{\mathrm{T} * \mathrm{C}_{\mathrm{p}, \text { water }} * \phi_{\mathrm{m}, \text { latex }}}{\Delta_{\text {vap }} \mathrm{h}} \\
& \phi_{\text {steam }}=\frac{15 * 4.2 * 6000}{2257.8}\left[\frac{\mathrm{kJ} / \mathrm{hr}}{\mathrm{kJ} / \mathrm{kg}}\right]=170\left[\frac{\mathrm{kg}}{\mathrm{hr}}\right]
\end{aligned}
$$

In the continuous stripping process, the latex stream first needs to be heated before entering the column. The amount of steam required to heat the latex from $15{ }^{\circ} \mathrm{C}$ to $100{ }^{\circ} \mathrm{C}$, see Equations D.3 to D.5.

$\phi_{\mathrm{q}}$, (heat exchanger $)=\phi_{\mathrm{m}, \text { latex }}{ }^{*} \mathrm{C}_{\mathrm{P}, \text { latex }} * \Delta \mathrm{T}$

$\phi_{\mathrm{q}}($ heat exchanger $)=1.67 * 2.9 * 85 \cong 411[\mathrm{~kW}]$

$\phi_{\text {steam }}=\frac{411 * 3600}{2257.8}\left[\frac{\mathrm{kJ} / \mathrm{hr}}{\mathrm{kJ} / \mathrm{kg}}\right]=655\left[\frac{\mathrm{kg}}{\mathrm{hr}}\right]$ 




\title{
Chapter 6
}

\section{High pressure carbon dioxide in the extraction of residual monomer from latex products: additional results and outlook}

\begin{abstract}
In retrospect to the previous chapters, this final chapter gives a perspective on some challenges in the extraction of residual monomer from latex products with high pressure carbon dioxide.
\end{abstract}

\section{Monomer partitioning}

The partition coefficient $\left(\mathrm{K}_{\text {mon }}\right)$ of the distribution of monomer between $\mathrm{CO}_{2}$-swollen polymer and $\mathrm{CO}_{2}$ is the key issue in the extraction of residual monomer from latex with $\mathrm{scCO}_{2}$. The phase behavior of a ternary system monomer- $\mathrm{CO}_{2}$-Swollen polymer- $\mathrm{CO}_{2}$ is often estimated by thermodynamic models based on the component properties. In Chapter 3 the large deviation between the experimentally determined and the theoretically predicted partition coefficient $\left(\mathrm{K}_{\text {mon }}\right)$ of the distribution of monomer between $\mathrm{CO}_{2}$-swollen polymer and $\mathrm{CO}_{2}$ has been discussed. The polymers used in the present work have not been submitted to annealing before experimental data have been collected. The polymer properties found in literature as well as in the VLXE software (Laursen, 2003) databank, have been determined from polymers which have been tempered at temperatures above their glass transition temperature. The annealing process changes the polymer properties as it removes any history effects as well as contaminants (van de Ven, 1975, Huvard et al., 1980). A proper design of an extraction process for residual monomer reduction (and reduction of the level of other low molecular weight species) from reactor products demands for partitioning data based on the actual products formed during the polymerization. This will almost always mean 
that partition coefficients of residual monomer (and other relevant low molecular weight species) have to be determined by experiments.

\section{Colloidal stability}

One of the challenges in the reduction of residual monomer in polymer (latex) products by extraction with $(\mathrm{sc}) \mathrm{CO}_{2}$ is the release of $\mathrm{CO}_{2}$ dissolved in the polymer particles. A rapid pressure decrease leads to loss of colloidal stability, i.e. bubble formation and even foaming, probably leading to surface coagulation/fouling. Foaming can be suppressed by introducing a defoaming agent to the reactor product (Kelley et al., 1978). However, the characteristics of the latex product can change, i.e. discoloration, hardness, etc.. Note that application of defoaming agents adds contaminants to the latex product.

It has been observed experimentally ${ }^{1}$ that the first bottleneck in decreasing the pressure of a $\mathrm{scCO}_{2}$ - latex mixture is the $\mathrm{CO}_{2}$ phase transition point, when $\mathrm{CO}_{2}$ changes from the supercritical to the gas phase. The formation of gas bubbles in the latex may cause foaming as a result of the presence of surface active species. Depending on the speed of the pressure decrease, foaming is severe or moderate. Once the pressure is below the supercritical pressure of 73 bar, decrease of the pressure can be controlled better than close to the critical pressure. Decreasing the pressure from about 5 bar to atmospheric pressure is also accompanied with some undesired phenomena. Note that particles are still swollen with $\mathrm{CO}_{2}$ at these already low pressures. Release of $\mathrm{CO}_{2}$ is governed by mass transport. The time constant for transport of $\mathrm{CO}_{2}$ out of the particles to the gas phase is probably larger than the time constant for pressure decrease. So recording atmospheric pressure in the gas phase ignores the $\mathrm{CO}_{2}$ present in the particles. Waiting for about 15 minutes allows $\mathrm{CO}_{2}$ transport from the particles to the gas phase, leading to a pressure increase. Repeating the procedure of pressure decrease followed by $\mathrm{CO}_{2}$ gas release from the particles is accompanied by fouling affixed to the wall of the vessel containing the latex. Also flocs of polymer were observed. Note that about 15 minutes after a constant pressure of 1 atmosphere has been reached a coagulum free latex could be isolated. Industrial removal of

\footnotetext{
${ }^{1}$ In the optical high pressure cell described in Chapter 3, latex was loaded with $\mathrm{scCO}_{2}$ at 100 bar at 35 ${ }^{\circ} \mathrm{C}$. After 1 hour the pressure was relieved through a valve at the top of the high pressure cell.
} 
residual monomer with high pressure $\mathrm{CO}_{2}$ demands for filtration after complete pressure release. Also cleaning of the equipment wall is necessary on a regular basis. The preliminary observations make clear that an accurately controlled pressure decrease is a prerequisite for a proper performance of a residual monomer reduction process based on (sc) $\mathrm{CO}_{2}$-based extraction. Note that proper development of a pressure decrease procedure is also applicable for e.g. emulsion vinylchloride/polyvinylchloride systems in emulsion and suspension.

One of the alternative methods to allow for phase separation between the latex and the $\mathrm{CO}_{2}$ dissolved in the latex, is to chemically bind the $\mathrm{CO}_{2}$ by using a weak basic macroporous ion exchange resin. $\mathrm{CO}_{2}$ reacts directly with primary or secondary amines generating their respective carbamate salts (Riley et al., 1994), see Scheme 1 for the typical reversible reaction.

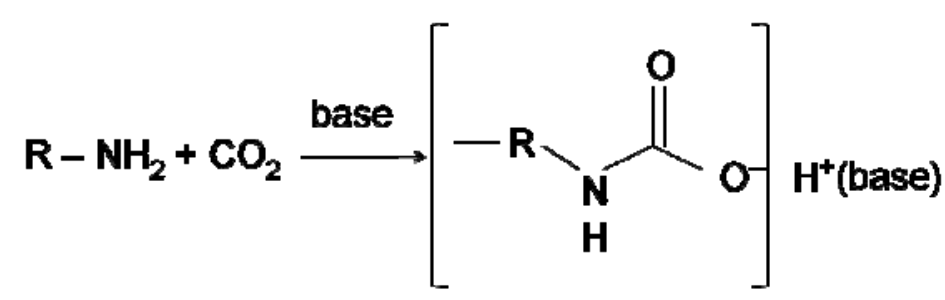

carbamate anion

Scheme 1. Reaction of amines with $\mathrm{CO}_{2}$.

The corresponding carbamate acid is not stable, only in the form of a sterically stabilized anion. The $\mathrm{CO}_{2}$ dissolved in the latex can be captured by a proper amine when the latex/CO mixture is led over a macroporous weak basic ion exchanger containing amine groups. Saha et al. (1999) as well as Samanta and Bandyopadhay (2009) discuss the kinetics as well as the modeling of the absorption of $\mathrm{CO}_{2}$ into aqueous solutions of the sterically hindered amine 2-amino-2-methyl-1-propanol (AMP). Bonenfant et al. (2007) studied the $\mathrm{CO}_{2}$ absorption capacities in aqueous 2-(2-aminoethylamino)ethanol (AEE) solutions. The authors mentioned reported experimental observations of $\mathrm{CO}_{2}$ absorption in amine solutions from $\mathrm{CO}_{2}$ containing gas streams. The pressure in such processes are low to moderate, $<100$ bar. Nevertheless absorption of $\mathrm{CO}_{2}$ by leading the latex $/ \mathrm{CO}_{2}$ mixture over an ion exchanger containing amine groups is a promising method to remove the $\mathrm{CO}_{2}$ from the latex. Ion 
exchange resins saturated with $\mathrm{CO}_{2}$ by the reaction presented in Scheme 1 can be thermally regenerated after washing out the latex particles with an amount of water as small as possible. During the thermal regeneration the carbamate dissociates in $\mathrm{CO}_{2}$ and the amine (note the analogy with the $\mathrm{CO}_{2}$ absorption process during the production synthesis gas for ammonia synthesis).

\section{Equilibrium between water and $\mathrm{scCO}_{2}: \mathrm{pH}$-effects}

Water in contact with carbon dioxide is known to become acidic due to the formation and dissociation of carbonic acid, see Equation 1:

$\mathrm{CO}_{2}+\mathrm{H}_{2} \mathrm{O} \rightleftharpoons \mathrm{H}_{2} \mathrm{CO}_{3} \rightleftharpoons \mathrm{H}^{+}+\mathrm{HCO}_{3}^{-}$

Organic species in an acidic medium can take up a proton, decreasing their solubility in $\mathrm{CO}_{2}$. Thoews et al. (1995) measured the $\mathrm{pH}$ of water in contact with $\mathrm{CO}_{2}$ by observing UV-VIS spectra of a pH indicator. The $\mathrm{pH}$ of water in equilibrium with $\mathrm{scCO}_{2}$ at equilibrium has been found to be only slightly dependent of temperature in the range between 25 and $70{ }^{\circ} \mathrm{C}$ at pressures ranging from 70 to 200 bar. Toews et al. (1995) reported a pH of water in equilibrium with $\mathrm{scCO}_{2}$ between 2.8 and 3 . Increasing pressure at constant temperature decreases the $\mathrm{pH}$. Increasing temperature at constant pressure increases the $\mathrm{pH}$, due to the lower solubility of $\mathrm{CO}_{2}$ in water at higher temperatures. The solubility behavior of $\mathrm{CO}_{2}$ in water at supercritical conditions for $\mathrm{CO}_{2}$ resembles that of liquid $\mathrm{CO}_{2}$ in equilibrium with water. The partial molar volume of liquid $\mathrm{CO}_{2}$ in water varies only slightly with pressure, hence the solubility of liquid $\mathrm{CO}_{2}$ in water is rather independent of pressure. $\mathrm{Li}$ and Duan (2007) report similar observations.

During the extraction of residual monomer from latex products with $\mathrm{scCO}_{2}$ the $\mathrm{pH}$ of the latex will decrease with respect to the $\mathrm{pH}$ of the reactor product. The colloidal stability of the latexes used in the experiments (vide supra), however, did not change. The latex used in the experiments varied in $\mathrm{pH}$ from 5 to 9 . 


\section{Life Cycle Assessment}

Green chemistry, low energy consumption, renewable resources, etc., are hot topics in process technology. The ecological footprint of a product or process has never been so emphasized as in the last two decades (Klöpffer, 2001-2006). Typically, a life cycle assessment (LCA) is made to identify, quantify, interpret and evaluate the environmental impact of a product or process. Van den Berg et al. (1995) defined LCA as a systematic evaluation of the environmental impact of products or activities from the resources entering the process to the ultimate waste disposal of the material. This so-called cradle-to-grave concept implies the identification and quantification of emissions and material consumption affecting the environment in all stages of the product life cycle. LCA is a diagnostic engineering tool which can be used to compare existing or novel products or processes or services with each other or with a standard.

Within LCA the definition of the system boundaries is very important. A functional unit determines which products or processes can be meaningfully compared to each other. Note, however, that in a comparative study, the compared products or processes are seldom exactly identical. Van den Berg et al. (1995) described two solutions for this problem: define a certain minimum level that all compared alternatives must obey, or leave qualitative differences between compared alternatives out of the LCA calculations and describe them in words. In either way, interpreting the LCA calculation results, one has to take into account the assumptions made in the functional unit definition.

In every LCA it is necessary to define which environmental impacts have to be taken into account. The International Organization for Standardization (ISO) published a series of standards, including only headlines for impact categories: resource use, ecological consequences and human health (ISO, 2007). In terms of more operational impact categories, several areas have been indicated, e.g. toxicity potential (human and/or ecotoxicity), energy consumption, global warming potential, acidification potential, land use, etc (Van den Berg et al., 1995). In the next step, i.e. characterization, the contribution of individual impacts per impact category has to be calculated. To perform this characterization process objectively, the characterization results are normalized, i.e. the results are divided by the actual or predicted magnitude for each impact category. Applying weighting factors, a 
single score or index for the total environmental impact of a product or process is obtained. In the last stage of LCA, all previous stages and the assumptions made therein need to be interpreted and evaluated. The robustness of the results needs to be tested, i.e. to check whether conclusions hold even if critical and/or approximate data are changed. Such evaluations typically cover sensitivity analysis, uncertainty analysis and data quality assessment. Nevertheless, discussions on the methodology followed, and especially on the choice of the functional unit, remains an important issue in the field of LCA.

Comparing the steam stripping process with the $\mathrm{scCO}_{2}$-based extraction process to reduce residual monomer in latex products, the functional unit in an LCA can be assigned as the residual monomer level in the latex. In this way the environmental impacts of each separation process, i.e. steam stripping or extraction with $\mathrm{scCO}_{2}$, can be unambiguously compared. The difficulty in interpreting the LCA results is hidden in the thermodynamic and transport limitations of the steam stripping process to reduce the residual monomer level. The monomer activity coefficient and as a consequence the monomer saturated vapor pressure in the polymer phase, respectively in the surrounding vapor phase are very low at high conversions $(X>99 \%)$. Consequently, monomer partitioning between the polymer phase and the steam phase is very low towards the vapor phase, see Equation 2.

$\mathrm{y}_{\mathrm{m}} * \mathrm{P}_{\text {total }}=\gamma_{\mathrm{m}} * \mathrm{x}_{\mathrm{m}} * \mathrm{P}_{\mathrm{m}}^{\text {sat }}$

In contrast to the $\mathrm{CO}_{2}$ extraction process, where the polymer phase is swollen with (sc) $\mathrm{CO}_{2}$ increasing the monomer activity coefficient in the polymer phase with respect to the unswollen polymer, the partition coefficient decreases with decreasing monomer mole fraction in the polymer phase $\left(\phi_{\mathrm{P}}\right)$, see Chapter 1, Figure 1. For low mole fractions of monomer there is no driving force for monomer transfer to the vapor phase. Moreover, the molecular diffusion coefficient of monomer in the polymer phase is very low $\left(D_{m}^{\mathrm{P}} \leq 10^{-15}\left[\frac{\mathrm{m}^{2}}{\mathrm{~s}}\right]\right)$, i.e. there is high mass transfer resistance in the particle phase.

For some polymeric latexes a reduction to 60 parts per million (ppm) residual monomer has been reported (Araújo et al., 2002). In the present work a final level of residual monomer in the latex product of $100 \mathrm{ppm}$ has been chosen as the lowest level of the residual monomer in the latex with steam stripping. $\mathrm{ScCO}_{2}$ as extraction medium is able to reduce the residual monomer level in latex to $1 \mathrm{ppm}$ with a slightly higher $\mathrm{CO}_{2}$ flow compared to a residual 
monomer reduction to $100 \mathrm{ppm}$. For a reduction of residual styrene in PS latex from $10^{4} \mathrm{ppm}$ to $100 \mathrm{ppm} 3000 \mathrm{~kg} \mathrm{scCO} / \mathrm{hr}$ is needed with a concentration of $90 \mathrm{~mol}$ styrene/ $\mathrm{m}^{3} \mathrm{scCO}_{2}$ in the outgoing $\mathrm{CO}_{2}$ flow. Under the same circumstances, $3025 \mathrm{~kg} \mathrm{scCO} / \mathrm{hr}$ is required to reduce the residual styrene level in PS latex from $10^{4} \mathrm{ppm}$ to $1 \mathrm{ppm}$.

Applying a LCA to study the environmental impact of the $\mathrm{scCO}_{2}$ based extraction process compared to the steam stripping to reduce residual monomer in latex delivers knowledge on emission, energy consumption, etc.. However, the monomer reduction in latex with $\mathrm{scCO}_{2}$ extraction to only $1 \mathrm{ppm}$ may counter balance the impact factors.

\section{Concluding remarks}

The work described in this thesis covers several important aspects of residual monomer reduction in polymer products. High pressure or $\mathrm{scCO}_{2}$ has the potential to decrease time constants for monomer transport in the polymer phase as well as to reach very low levels of the residual monomer concentration in polymers (1 ppm) with a relatively small equipment size. Performance compared with common techniques like steam stripping is better as the final residual monomer level aimed at becomes lower.

Although the implementation of high pressure or $\mathrm{scCO}_{2}$ in residual monomer reduction needs to be further explored, the author of this thesis believes that the described $\mathrm{CO}_{2}$ extraction-based process allows for the production of cleaner and greener polymer products. Consequently, the developed methodology also provides an technical answer to the increasingly stringent regulations in this respect. 


\section{References}

P. H. H. Aaújo, C. Sayer, J. G. R. Poço, R. Guidici, "Techniques for reducing residual monomer content in polymers: A review", Polym. Eng. Sci., 2002, 42, 7

N. W. van den Berg, C. E. Dutilh, G. Huppes, "Beginning life cycle assessment: A guide into environmental life cycle assessment", 1995, Leiden

D. Li, Z. Duan, "The speciation equilibrium coupling with phase equilibrium in the $\mathrm{H}_{2} \mathrm{O}-\mathrm{CO}_{2}$ $\mathrm{NaCl}$ system from 0 to $250^{\circ} \mathrm{C}$, from 0 to 1000 bar, and from 0 to 5 molality of $\mathrm{NaCl}$ ", Chem. Geology, 2007, 244, 730-751

ISO 14001 Management Zone, UK, 2007, http://www.iso-14001.org.uk

E. L. Kelley, R. W. Harrison, B. B. Harris, "Defoamers: their theory and application with regard to the paint industry", Polym., Paint and Colour J., 1978, 168, 734

W. Klöpffer, Ed., Int. J. of Life Cycle Assessment, 2001 - 2011

J. H. Perry, Chapter 16, "Adsorption and ion exchange" in "Chemical Engineer's Handbook", 1999, McGraw-Hill, New York

D. Riley, W. D. McGhee, T. Waldman, "Generation of urethanes and isocyanates from amines and carbon dioxide", Am. Chem. Soc., 1994, 122-132.

K. L. Toews, R. M. Shroll, C. M. Wai, "pH - Defining equilibrium between water and supercritical $\mathrm{CO}_{2}$. Influence on SFE of organics and metal chelates", Anal. Chem., 1995, 67, 4040-4043 




\section{Notation}

\section{Abbreviations}

eos

equation of state

f.o.b.

free on board

MMA

methyl methacrylate

MWBR

Modified Webb Benedict Ruben

PMMA

polymethyl methacrylate

ppm

parts per million

PC-SAFT

perturbed chain-statistical associated fluid theory

PR

Peng -Robinson

PS

polystyrene

SF

solid-to-fluid

SLF

solid-to-liquid-to-fluid

Sty

styrene

VLLE

vapor-liquid-liquid equilibrium

\section{Symbols}

a

first parameter in the Colver theory $\left(=\frac{\gamma_{p 1}}{\gamma_{21}}\right)[-]$ (Chapter4)

$a(T, \omega)$

attraction parameter used in the Peng-Robinson equation of state $\left[\mathrm{Nm}^{4} / \mathrm{mol}^{2}\right]$

$a_{\text {eff }}$

$a_{i}$

$a_{i j}$

$a_{i j}$

$a_{\text {mix }}$

A

$A_{i}$ effective specific mass transfer area $\left[\frac{m_{i j}^{2}}{m_{i j}^{3}}\right]$

Peng-Robinson attraction parameter for pure component i $\left[\mathrm{Nm}^{4} / \mathrm{mol}^{2}\right]$ cross attraction parameter used in Peng-Robinson equation of state $\left[\mathrm{Nm}^{4} / \mathrm{mol}^{2}\right]$

total specific interfacial area $\left[\frac{m_{i j}^{2}}{m_{i j}^{3}}\right]$

Peng-Robinson attraction parameter for a mixture $\left[\mathrm{Nm}^{4} / \mathrm{mol}^{2}\right]$

constant defined in equation 10, Chapter $2[-]$

area i $\left[\mathrm{m}^{2}\right]$ 


\begin{tabular}{|c|c|}
\hline$A_{i}$ & interfacial area of the $\mathrm{i}^{\text {th }}$ interface $\left[\mathrm{m}^{2}\right]$ \\
\hline$A^{\text {assoc }}$ & Helmholtz energy covering the association contribution [J] \\
\hline$A^{\text {disp }}$ & Helmholtz energy covering the dispersion contribution [J] \\
\hline$A^{\text {hc }}$ & Helmholtz energy covering the hard chain contribution $[\mathrm{J}]$ \\
\hline$A^{\text {pert }}$ & Helmholtz energy covering the perturbation contribution $[\mathrm{J}]$ \\
\hline$A^{\text {ref }}$ & Helmholtz energy of the reference system [J] \\
\hline$A^{\text {res }}$ & residual Helmholtz energy $[\mathrm{J}]$ \\
\hline$b$ & second parameter in the Colver theory $\left(=\frac{\gamma_{p 2}}{\gamma_{21}}\right)[-]($ Chapter 4$)$ \\
\hline $\mathrm{b}$ & $\begin{array}{l}\text { volume parameter used in the Peng-Robinson equation of state } \\
{\left[\mathrm{m}^{3} / \mathrm{mol}\right]}\end{array}$ \\
\hline$b_{i}$ & Peng-Robinson volume parameter for pure component i [m³/mol] \\
\hline $\mathrm{b}_{\text {mix }}$ & Peng-Robinson volume parameter for a mixture $\left[\mathrm{m}^{3} / \mathrm{mol}\right]$ \\
\hline $\mathrm{B}$ & constant defined in equation 11 , Chapter $2[-]$ \\
\hline $\mathrm{C}$ & constant factor \\
\hline $\mathrm{C}_{\mathrm{D}}$ & drag coefficient [-] \\
\hline $\mathrm{C}_{0}$ & monomer concentration in the center of the polymer particle $\left[\frac{\mathrm{mol}}{\mathrm{m}^{3}}\right]$ \\
\hline $\mathrm{C}_{\mathrm{P}, \mathrm{i}}$ & specific heat of phase i $\left[\frac{\mathrm{kJ}}{\mathrm{kg}^{\circ} \mathrm{C}}\right]$ \\
\hline $\mathrm{C}_{\mathrm{s}}$ & monomer concentration at the surface of the polymer particle $\left[\frac{\mathrm{mol}}{\mathrm{m}^{3}}\right]$ \\
\hline $\mathrm{C}_{\text {mon }}^{\mathrm{i}}$ & $\begin{array}{l}\text { equilibrium monomer concentration in phase i } \\
\text { [mol monomer / kg phase i] }\end{array}$ \\
\hline $\mathrm{D}_{\mathrm{c}}$ & column diameter $[\mathrm{m}]$ \\
\hline$d_{i}$ & diameter of sphere i [m] \\
\hline$d_{\text {particle }}$ & diameter of polymer particle [m] \\
\hline$D_{m}^{i}$ & diffusion coefficient of monomer $\mathrm{m}$ in phase i $\left[\frac{\mathrm{m}^{2}}{\mathrm{~s}}\right]$ \\
\hline$f_{i}$ & fugacity of a pure component i $[\mathrm{Pa}]$ \\
\hline$\hat{\mathrm{f}}_{\mathrm{i}}$ & fugacity of component $i$ in a mixture $[\mathrm{Pa}]$ \\
\hline$f_{i}^{\circ}$ & standard fugacity of component i [Pa] \\
\hline $\mathrm{f}_{\mathrm{i}}^{(\mathrm{n})}$ & fugacity of component $i$ in phase $n[P a]$ \\
\hline $\mathrm{F}_{\mathrm{B}}$ & buoyant force $[\mathrm{N}]$ \\
\hline$F_{D}$ & drag force $[\mathrm{N}]$ \\
\hline
\end{tabular}


$F_{G}$

Fo

g

$\mathrm{G}_{0}$

$\mathrm{G}_{\mathrm{m}}$

$\mathrm{G}_{\mathrm{i}}^{0}$

$\mathrm{G}_{\mathrm{m}}{ }^{\mathrm{E}}$

$\Delta \mathrm{G}$

$\Delta G_{i}$

$\Delta_{\text {mix }} G_{m}$

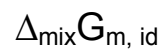

$\Delta \Delta \mathrm{G}_{\text {solution }}$

$\mathrm{h}$

$\mathrm{H}_{\mathrm{c}}$

$\mathrm{H}_{\mathrm{c}, \mathrm{n}}$

$\mathrm{H}_{\text {HETP }}$

$\mathrm{H}_{\mathrm{m}}$

$\mathrm{H}_{\mathrm{i}}^{\circ}$

$\Delta \Delta \mathrm{H}_{\text {solution }}$

$k_{b}$

$k_{m}^{i}$

$\mathrm{k}_{\mathrm{ij}}$

$\mathrm{K}_{\mathrm{i}}$

$\mathrm{K}_{\text {mon }}$

$\mathrm{K}_{\text {mon }}^{\mathrm{T}_{\mathrm{i}}}$

$\mathrm{I}_{\mathrm{BF}}$

m external force [N]

Fourier number [-]

gravitational force $\left[\mathrm{m} / \mathrm{s}^{2}\right]$

total energy of a solid-liquid-liquid system [-]

molar Gibbs free energy [J mole ${ }^{-1}$ ]

standard molar Gibbs energy [ $\left.\mathrm{J} \mathrm{mole}^{-1}\right]$

excess molar Gibbs energy [ $\left.\mathrm{J} \mathrm{mole}^{-1}\right]$

Gibbs free energy change [J]

energy difference of phase I with respect to the minimal energy [-]

molar Gibbs energy of mixing [ $\left.\mathrm{J} \mathrm{mole}^{-1}\right]$

molar Gibbs energy of mixing to form an ideal mixture [ $\mathrm{J} \mathrm{mole}^{-1}$ ]

difference in Gibbs free energy of solution of monomer dissolved in $\mathrm{CO}_{2}$ and of monomer dissolved in $\mathrm{CO}_{2}$ swollen polymer [ $\mathrm{J}$ mole ${ }^{-1}$ ]

enthalpy per $\mathrm{kg}[\mathrm{kJ} / \mathrm{kg}]$

column height $[\mathrm{m}]$

column height when $\mathrm{n}$ ppm residual monomer is reached

height equivalent of a theoretical plate $[\mathrm{m}]$

enthalpy of mixing [ $\mathrm{J}$ mole $\left.{ }^{-1}\right]$

standard enthalpy $\left[\mathrm{J} \mathrm{mole}^{-1}\right]$

difference in heat of solution of monomer dissolved in $\mathrm{CO}_{2}$ and monomer dissolved in $\mathrm{CO}_{2}$ swollen polymer [ $\mathrm{J} \mathrm{mole}^{-1}$ ]

Boltzman constant, $1.38 * 10^{-23}\left[\frac{J}{K}\right]$

partial mass transfer coefficient of monomer in phase i $\left[\frac{\mathrm{m}}{\mathrm{s}}\right]$

binary interaction parameter accounting for the interaction of unlike molecules [-]

partition coefficient of monomer $\mathrm{i}$ between $(\mathrm{sc}) \mathrm{CO}_{2}$ and polymer $\mathrm{i}$ [kg polymer/ $\mathrm{kg}(\mathrm{sc}) \mathrm{CO}_{2}$ ]

partition coefficient of monomer between $(\mathrm{sc}) \mathrm{CO}_{2}$ and polymer [kg polymer/ $\left.\mathrm{kg}(\mathrm{sc}) \mathrm{CO}_{2}\right]$

partition coefficient of monomer between the $(\mathrm{sc}) \mathrm{CO}_{2}$ and polymer at temperature $\mathrm{T}_{\mathrm{i}}$ [kg polymer/ $\left.\mathrm{kg}(\mathrm{sc}) \mathrm{CO}_{2}\right]$

mean free path of base fluid $\left(l_{H_{2} O}=0.17 \mathrm{~nm}\right)[\mathrm{m}]$

number of segments [-] 


\begin{tabular}{|c|c|}
\hline$m_{\text {sphere }}$ & mass of sphere [kg] \\
\hline$M_{i}$ & mass of species i [kg] \\
\hline$M_{w}$ & weight averaged molecular weight $[\mathrm{kg} / \mathrm{mol}]$ \\
\hline $\mathrm{N}_{\mathrm{ts}}$ & number of theoretical stages [-] \\
\hline $\mathrm{n}$ & total number of molecules $[-]$ \\
\hline $\mathrm{n}_{\mathrm{i}}$ & number of molecules of component i [-] \\
\hline$P$ & pressure $[\mathrm{Pa}]$ \\
\hline$P_{A}$ & attractive term of pressure $[\mathrm{Pa}]$ \\
\hline$P_{c}$ & critical pressure $[\mathrm{Pa}]$ \\
\hline$P_{R}$ & repulsive term of pressure $[\mathrm{Pa}]$ \\
\hline$P_{\text {total }}$ & total pressure of the system [bar] \\
\hline $\mathrm{p}(\mathrm{I})$ & coefficient number I, defined in Appendix B, Chapter 3 \\
\hline $\mathrm{P}_{\mathrm{m}}^{\mathrm{sat}}$ & monomer saturated vapor pressure [bar] \\
\hline $\mathrm{R}$ & gas constant $\left[8.314 \mathrm{~J} \mathrm{~mole}^{-1} \mathrm{~K}^{-1}\right]$ \\
\hline $\operatorname{Re}$ & Reynolds number [-] \\
\hline $\mathrm{R}_{\mathrm{P}}$ & polymer particle radius [m] \\
\hline$r_{p}$ & polymer particle radius $[\mathrm{m}]$ \\
\hline$r_{\mathrm{s}}$ & $\begin{array}{l}\text { steam flow rate }[\mathrm{kg} \text { steam } / \mathrm{kg} \text { dry solids s] (from personal } \\
\text { communication) }\end{array}$ \\
\hline s & isentropy $\left[\mathrm{kcal} /{ }^{\circ} \mathrm{C}\right]$ \\
\hline$\Delta s$ & distance a particle travels in the interfacial region [m] \\
\hline $\mathrm{S}_{\mathrm{i}}$ & spreading coefficient of phase i [-] \\
\hline$S_{i}^{\circ}$ & standard entropy $\left[\mathrm{J} \mathrm{mole}^{-1} \mathrm{~K}^{-1}\right]$ \\
\hline Sh & Sherwood number [-] \\
\hline$S_{m}$ & entropy of mixing $\left[\mathrm{J}\right.$ mole ${ }^{-1} \mathrm{~K}^{-1}$ ] \\
\hline$t_{\text {contact, } i}$ & contact time of phase i [s] \\
\hline $\mathrm{T}$ & temperature $[\mathrm{K}]$ \\
\hline $\mathrm{T}_{\mathrm{c}}$ & critical temperature $[\mathrm{K}]$ \\
\hline $\mathrm{T}_{\mathrm{g}}$ & glass transition temperature $[\mathrm{K}]$ \\
\hline $\mathrm{T}_{\mathrm{r}}$ & reduced temperature $[-]$ \\
\hline$\Delta \mathrm{T}_{\ln }$ & logarithmic mean temperature difference $[\mathrm{K}][$ \\
\hline
\end{tabular}


u

U

v

$\mathrm{v}_{\mathrm{Br}}$

$\mathrm{v}_{\mathrm{c}}$

$v_{d}$

$v_{\mathrm{i}}$

$v_{s}$

$\mathrm{V}_{\infty}$

V

$x_{i}$

$X$

$y_{i}$

$w_{i}$

Z

z

$\mathrm{z}_{0}$

$\mathrm{z}_{0}^{\min }$

\section{Greek letters}

$a_{\mathrm{i}}$

$\delta_{i}$

$\varepsilon_{\mathrm{d}}$

$\epsilon / k$

$\varphi_{i}^{I}$

$\phi_{i}$

$\phi_{\mathrm{q}}$

internal energy [kJ/kg]

overall heat transfer coefficient $\left[\frac{W}{m^{2}{ }^{\circ} \mathrm{C}}\right]$

molar volume $\left[\mathrm{m}^{3} / \mathrm{mol}\right]$

Brownian velocity of the polymer particles $\left[\frac{m}{s}\right]$

superficial velocity of the continuous phase $\left[\frac{m}{s}\right]$

superficial velocity of the dispersed phase $\left[\frac{m}{s}\right]$

molar volume of component i [ $\left.\mathrm{m}^{3} / \mathrm{mol}\right]$

slip velocity $\left[\frac{m}{s}\right]$

hindered rising velocity of one bubble $\left[\frac{m}{s}\right]$

volume $\left[\mathrm{m}^{3}\right]$

molar fraction of component $i$ in the liquid phase [-]

conversion [-]

molar fraction of component $i$ in the vapor phase [-]

weigth fraction of component i [-]

compressibility factor, defined in equation $12[-]$

particle's position with respect to the interface [m]

ratio of the particles position with respect to the interface over the particle radius [-]

particle's equilibrium position $(=b-a)[-]$

activity of component i [-]

boundary layer thickness of phase i [m]

dispersed phase hold up $\left[\frac{\mathrm{m}^{3} \text { dispersed phase }}{\mathrm{m}^{3} \text { column }}\right]$

energy related to the interaction of two segments $[\mathrm{K}]$

fugacity coefficient of component $i$ in phase I [-]

mass flow rate of phase i $\left[\frac{\mathrm{kg}}{\mathrm{hr}}\right]$ or $\left[\frac{\mathrm{kg}}{\mathrm{s}}\right]$

heat flow $[\mathrm{kW}]$ 


\begin{tabular}{|c|c|}
\hline$\phi_{\mathrm{w}, \mathrm{shaft}}$ & shaft work $[\mathrm{kW}]$ \\
\hline$\Phi_{P}$ & polymer volume fraction [-] \\
\hline$\gamma_{i}$ & activity coefficient of component i [-] \\
\hline$\gamma_{i j}$ & interfacial tension between phase i and j $\left[\frac{m N}{m}\right]$ \\
\hline$\gamma_{m}$ & monomer activity coefficient [-] \\
\hline$\lambda$ & thermal conductivity coefficient $\left[\frac{\mathrm{W}}{\mathrm{m}^{\circ} \mathrm{C}}\right]$ \\
\hline$\eta$ & dynamic viscosity of $\mathrm{H}_{2} \mathrm{O}$ [Pa s] \\
\hline$\mu_{\mathrm{i}}$ & chemical potential of component $\mathrm{i}\left[\mathrm{J}\right.$ mole $\left.{ }^{-1}\right]$ \\
\hline$\mu_{\mathrm{i}}^{\circ}$ & standard chemical potential of component i [ $\left.\mathrm{J} \mathrm{mole}^{-1}\right]$ \\
\hline$\mu_{\mathrm{i}}^{\mathrm{E}}$ & excess chemical potential of component i [ $\left.\mathrm{J} \mathrm{mole}^{-1}\right]$ \\
\hline$\mu_{\mathrm{i}, \mathrm{id}}$ & chemical potential of component i of an ideal mixture $\left[\mathrm{J} \mathrm{mole}^{-1}\right]$ \\
\hline$\rho$ & density $\left[\frac{\mathrm{kg}}{\mathrm{m}^{3}}\right]$ \\
\hline$\sigma$ & size of segments $[\AA]$ \\
\hline$\tau_{n}$ & $\begin{array}{l}\text { residence time of } \mathrm{CO}_{2} \text { bubbles in the column when } \mathrm{n} \text { residual monomer } \\
\text { level is reached [s] }\end{array}$ \\
\hline$\theta$ & fraction of the interfacial area covered with polymer particles [-] \\
\hline$\omega$ & acentric factor [-] \\
\hline
\end{tabular}






\section{Dankwoord}

Aan het einde van mijn promotieonderzoek kan ik terugkijken op een intensieve, leerrijke en aangename periode in mijn leven. Natuurlijk zijn er heel veel mensen die hier op een of andere manier toe hebben bijgedragen en ik wil hen dan ook graag bedanken.

Allereerst wil ik mijn promotor Jos Keurentjes bedanken voor de mogelijkheid dit ongelofelijk interessante promotieonderzoek uit te voeren. Dankjewel voor je vertrouwen en aanmoedigingen, voor je enthousiasme en klare kijk op zoveel dingen. Ik heb genoten van onze gesprekken, zowel binnen als buiten het project, waardoor ik altijd weer een duidelijke en open visie kreeg om de toekomst met vernieuwd enthousiasme tegemoet te gaan.

Ook wil ik graag mijn dagelijkse begeleiders bedanken. In het eerste deel van de promotie was Maartje Kemmere hierin de aandrijvende kracht. Maartje, ik heb veel van je geleerd, zowel op professioneel als op persoonlijk vlak. Dankjewel, ik zal je nooit vergeten. Jan Meuldijk werd mijn nieuwe toeverlaat, een keuze die heel snel gemaakt werd. Jan, zoals je zelf dikwijls hebt vermeld, hebben we ondertussen al een heel verleden samen. Van het allereerste begin in Diepenbeek, april 2001, tot nu heb ik genoten van onze samenwerking en jouw enorme kennis. Ook je bezorgdheid toen ik het moeilijker had, en vooral je positieve kijk, stel ik enorm op prijs. Ik kijk ernaar uit om nog veel met jou te mogen samenwerken.

Dan zijn er nog de enthousiaste studenten die aan dit project hebben meegewerkt. Inge, Tijl, Roel, Rob, Harro, Kirill, Willeke, Judith en Simone, hartelijk dank voor jullie inzet.

Chris, Dolf en Erik, bedankt voor jullie hulp om mijn opstelling draaiende te houden.

Dank aan mijn collega's van SPD voor de fijne sfeer, zelfs wanneer we in aantal verminderden. Ik heb veel gelachen en plezier beleefd. Speciale dank aan mijn paranimfen, Fabiènne en Carin, collega's en vriendinnen. Jullie weten wat jullie voor mij betekend hebben tijdens de promotie en daarnaast. Danku!

Tot slot een dank aan mijn familie. Mama, papa, Anja, Michele, Nele en Livio, bedankt voor jullie ondersteuning en onaflatende interesse in mijn werk en natuurlijk ook de fijne momenten van ontspanning die zeker nodig waren! Moeke en papa, danku voor alles wat jullie me gegeven hebben. Wat ik ook bereikt heb in mijn leven, op welk gebied dan ook, heb ik aan jullie steun en liefde te danken. Danku voor de mogelijkheden die ik heb gekregen, voor de aanmoedigingen, voor alle levenslessen, danku voor alles. Ook mijn lieve Paulien wil ik danken om in mij te geloven. Je bent een prachtig persoon die heel veel te geven heeft. Ik ben er fier op jouw zus te zijn!

Steve, jij bent mijn toeverlaat, mijn leven, mijn beste vriend. Tijdens de mooie momenten was je er, maar nog meer tijdens de moeilijke momenten. Mijn leven delen met jou maakt de wereld zoveel mooier...en het beste moet nog komen. 



\section{Curriculum Vitae}

Marijke Aerts was born on January $2^{\text {nd }} 1982$ in Hasselt (Belgium). In 2000, she finalized her secondary education at Lyceum (Atheneum III) in Hasselt. In October of that year, she started studying chemistry at Hasselt University (Diepenbeek, Belgium). After completion of her second year candidature in 2002, she continued her education in chemical engineering at the Department of Chemical Engineering and Chemistry of the Eindhoven University of Technology (The Netherlands). She performed her MSc graduation project entitled "Synthesis of polyurethanes with carbon dioxide" in the Process Development Group. In August 2005 she received her MSc degree in Chemical Engineering. From October 2005 till December 2010, she performed a PhD graduation project in the Process Development Group under supervision of prof.dr.ir. J.T.F. Keurentjes and prof.dr. J. Meuldijk. The subject of the project was reduction of residual monomer in polymer latex products with high pressure carbon dioxide. The results of this research project sponsored by the Foundation Emulsion Polymerization, are summarized in this thesis. As from September $1^{\text {st }} 2011$, she is working as a process development engineer at Bodec Process Technology in Best (The Netherlands). 